\author{
UNIVERSIDADE DE SÃO PAULO \\ ESCOLA DE ENGENHARIA DE SÃO CARLOS \\ PROGRAMA DE PÓS-GRADUAÇÃO EM GEOTECNIA
}

CAHIO GUIMARÃES SEABRA EIRAS

Mapeamento da suscetibilidade a eventos perigosos de natureza geológica e hidrológica em São Carlos - SP. 



\section{CAHIO GUIMARÃES SEABRA EIRAS}

\section{Mapeamento da suscetibilidade a eventos perigosos de natureza geológica e hidrológica em São Carlos - SP.}

Dissertação apresentada à Escola de Engenharia de São Carlos da Universidade de São Paulo para obtenção do título de Mestre em Ciências, Programa de Pós Graduação em Geotecnia

VERSÃO CORRIGIDA

Orientador: Prof. Dr. Oswaldo Augusto Filho

São Carlos - SP 
AUTORIZO A REPRODUÇÃO TOTAL OU PARCIAL DESTE TRABALHO, POR QUALQUER MEIO CONVENCIONAL OU ELETRÔNICO, PARA FINS DE ESTUDO E PESQUISA, DESDE QUE CITADA A FONTE.

E34m

Eiras, Cahio Guimarães Seabra

Mapeamento da suscetibilidade a eventos perigosos de natureza geológica e hidrológica em São Carlos SP. / Cahio Guimarães Seabra Eiras; orientador oswaldo Augusto Filho. São Carlos, 2017.

Dissertação (Mestrado) - Programa de Pós-Graduação e Área de Concentração em Geotecnia -- Escola de Engenharia de São Carlos da Universidade de São Paulo, 2017 .

1. Enchentes/Inundações. 2. Movimentos de encosta. 3. Erosão Pluvial. 4. Solos colapsíveis. 5. Probabilidade inicial. 6. SIG. 7. Defesa Civil. I. Titulo. 


\section{FOLHA DE JULGAMENTO}

\section{Candidato: CAHIO GUIMARĀES SEABRA EIRAS}

Título da dissertaçāo: "Mapeamento da suscetibilidade a eventos perigosos de natureza geológica e hidrológica em Säo Carlos - SP"

Data da defesa: 07/07/2017

Comissão Julgadora:

Prof. Associado Oswaldo Augusto Filho

(Orientador)

(Escola de Engenharia de Säo Carlos/EESC)
Resultado:

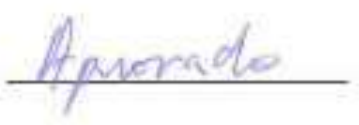

Prof. Dr. José Augusto de Lollo

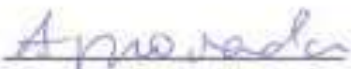

(Universidade Estadual Paulista "Júlio de Mesquita Filho"/UNESP + Ilha Solteira)

Prof. Dr. Reinaldo Lorandi

(Universidade Federal de São Carlos/UFSCar)

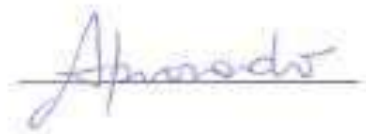

Coordenador do Programa de Pós-Graduaçâo em Geotecnia:

Prof. Dr. Edmundo Rogério Esquivel

Presidente da Comissão de Pós-Graduaçāo:

Prof. Associado Luis Fernando Costa Alberto 

A Deus, pela presença em todos os momentos da minha vida e aos meus pais, meus exemplos, pelo constante apoio e amor incondicional. 



\section{AGRADECIMENTOS}

Primeiramente agradeço a Deus, pela inspiração, estar comigo em todos os momentos da minha vida e sempre acreditar em mim.

Aos meus pais pelo amor incondicional, incentivo, apoio e exemplo, hoje tudo que sou, em grande parte, é graças a vocês. Aos meus irmãos pela amizade verdadeira, conselhos e companheirismo.

Ao meu orientador Prof. Dr. Oswaldo Augusto Filho, pela oportunidade concedida, pela paciência em me orientar nesta pesquisa, apoio, conselhos, momentos de descontração e grande contribuição no meu crescimento profissional.

Ao Diretor da Defesa Civil de São Carlos - SP, Sr. Pedro Caballero pelo fundamental apoio dado a esta pesquisa e ensinamentos transmitidos.

Ao Departamento de Geotecnia da Escola de Engenharia de São Carlos pela infraestrutura oferecida, a todos os professores, em especial ao Prof. Lázaro, Prof. Jefferson, Prof. Rogério, Prof. Orêncio, Prof. Tarcísio e a Prof ${ }^{\mathrm{a}}$ Valéria. Aos técnicos, em especial ao Álvaro, Maristela, Neiva, Zé Luis, Benedito e Oscar.

Aos amigos de São Carlos, em especial: Gabriel Pedroso, Monique Neves, Denis Watashi, Yara Barbosa, Heider Castro, Jean, Gabriel Steluti, João, Túlio Queijo, Ayla Craig e a todos os amigos do departamento de Geotecnia. Aos amigos de Ouro Preto e Belo Horizonte, em especial Stênio, Lucas Gomes, Lincoln, Ana Virgínia, Edgar, Daniara, Yanne e Lucas Magalhães pela grande amizade. A Sylvia por ser uma grande companheira e sempre estar do meu lado, sempre me apoiando.

Aos funcionários da câmara municipal de São Carlos - SP, pelo auxílio dado na aquisição de dados para o trabalho.

Ao aluno de iniciação científica Paulo Sérgio da Silva Júnior por enriquecer esta pesquisa com dados do seu trabalho.

Ao Programa de Aperfeiçoamento de Ensino (PAE), pelo suporte financeiro e aprendizado profissional.

À Coordenação de Aperfeiçoamento de Pessoal de Nível Superior (CAPES), pela bolsa de mestrado concedida. 

"O mundo é um livro, e quem fica sentado em casa lê somente uma página" 



\section{RESUMO}

EIRAS, Cahio Guimarães Seabra. Mapeamento da suscetibilidade a eventos perigosos de natureza geológica e hidrológica em São Carlos - SP. 2017. 97 f. Dissertação (Mestrado em Geotecnia) - Departamento de Geotecnia, Universidade de São Paulo, São Carlos, 2017

Com a urbanização crescente no Brasil, o mapeamento de eventos perigosos mostra-se cada vez mais necessário para que se reduzam transtornos socioeconômicos nos municípios brasileiros. O objetivo principal da pesquisa foi elaborar mapas de suscetibilidade a eventos perigosos de natureza geológica e hidrológica, para a área urbana e de expansão urbana $\left(148,97 \mathrm{Km}^{2}\right)$ do município de São Carlos - SP. A análise foi feita em ambiente de SIG (Sistemas de Informação Geográfica), e combinou abordagens qualitativas e quantitativas de mapeamento de eventos perigosos, propostas pelo Working Group Committee on Risk Assessment (1997). Como método, analisou-se a frequiência dos eventos históricos em função da área $\left(\mathrm{Km}^{2}\right)$ dos condicionantes cartografados nos mapas temáticos (probabilidades iniciais). Os condicionantes foram analisados isoladamente e combinados, na forma de classes de terreno. O inventário dos registros históricos (482 registros) dos eventos foi feito com os dados de jornais, defesa civil e imagens de satélite entre os anos de 1965 a 2016. Foram elaborados os mapas de suscetibilidade para: movimentos de encosta, erosão pluvial, solos colapsíveis e enchentes/inundações. O método utilizado mostrou-se eficiente, visto que os objetivos da pesquisa foram alcançados. Foi possível validar os mapas de suscetibilidade, com as características do meio físico observadas em trabalhos de campo e dados de ensaios geotécnicos. Os eventos mais críticos para o município são as enchentes/inundações e alagamentos, erosões pluviais e movimentos de encostas causam pequenos transtornos, principalmente em consequência do relevo suave da região. Apesar da base cartográfica estar na escala 1:10.000, os mapas são apresentados na escala 1:20.000, com o objetivo destes serem impressos em papéis no formato A1.

Palavras-chave: Enchentes/Inundações. Movimentos de encosta. Erosão pluvial. Solos colapsíveis. Probabilidade inicial. SIG. Defesa Civil. 



\begin{abstract}
EIRAS, Cahio Guimarães Seabra. Susceptibility Mapping of geological and hydrological dangerous events in São Carlos - SP. 2017. 97 f. Dissertação (Mestrado em Geotecnia) Departamento de Geotecnia, Universidade de São Paulo, São Carlos, 2017
\end{abstract}

With the increasing urbanization in Brazil, hazardous events mapping has become increasingly necessary to reduce socioeconomic disorders in Brazilian citys. The main goal of the research was to elaborate susceptibility maps to dangerous events of geological and hydrological nature, for the urban area and urban expansion $(148,97 \mathrm{Km} 2)$ to the city of São Carlos - SP. The analysis was done in a GIS environment (Geographic Information Systems), and combined qualitative and quantitative approaches of hazardous events mapping, proposed by the Working Group Committee on Risk Assessment (1997). The frequency of historical events was analyzed according to the area of the conditioners mapped on the thematic maps (prior probabilitys). The conditioners were analyzed separately and then combined, in the form of land classes. The inventory of historical records (482 records) of events was done with acquired data from newspapers, civil defense and satellite images between the years 1965 to 2016. Susceptibility maps were developed for slope movements, water erosion, collapsible soils and floods. This method proved to be efficient, since the research objectives were achieved. It was possible to validate the susceptibility maps, with the characteristics of the physical environment observed in field work and geotechnical data. The most critical events in São Carlos are floods, rainfall erosions and slope movements cause minor damage, as a result of the region's soft relief. Although the cartographic base is in the 1: 10.000 scale, the maps are presented in the 1: 20.000 scale, with the purpose of being printed on A1 format paper.

Keywords: Floods. Slope movements. Water erosion. Collapsible soils. Prior probabilitys. GIS. Civil defense. 



\section{LISTA DE FIGURAS}

Figura 1: Número de pessoas afetadas por desastres naturais em todos os continentes (EMDAT, 2016).

Figura 2: Área urbana de São Carlos em destaque, com a respectiva localização no estado de São Paulo, e as folhas topográficas utilizadas na pesquisa. 36

Figura 3: Média pluviométrica mensal para os anos de 1959 a 2016 (DAEE, 2016). 38

Figura 4: Principais tipos de riscos ambientais com destaque para os de natureza geológica e hidrológica (Cerri 1993 apud Augusto Filho 2001).

Figura 5: Inundação em São Carlos no dia 23/11/2015. (EPTV. 2015). 52

Figura 6: Ilustração mostrando o movimento de A-rastejo; B- queda; C-corrida. Bobrowsky \& Highland (2008). 58

Figura 7: Processo de escorregamento planar. Bobrowsky \& Highland (2008). 59

Figura 8: Características do leito do rio. Tucci (2005). 60

Figura 9: Tipos fundamentais de estrutura de dados digitais em SIG 63

Figura 10: Estrutura dual e atribuída ao objeto para dados vetoriais em SIG. 64

Figura 11: Sequência de obtenção de informações para a elaboração de carta de suscetibilidade à erosão (PEJON; FERREIRA, 2015). 68

Figura 12: Método para elaboração de cartas de suscetibilidade para movimentos de encosta (AUGUSTO FILHO, 1995).

Figura 13: Classes de terreno possíveis resultantes do cruzamento dos mapas temáticos......82 82

Figura 14: Malha de pontos no software ArcGis $10.3^{\circledR}$, em detalhe a imagem 1 . 85

Figura 15:Mosaico de imagens de satélite obtidas a partir do Google Earth Pro ${ }^{\circledR}$. 86

Figura 16: Modelo digital de terreno (MDT) da área de estudos. 87 
Figura 17: Localização dos postos pluviométricos (SILVA JÚNIOR, 2016) 94

Figura 18: Talude na avenida integração. 97

Figura 19: (A) Local na cidade de Aracy, (B) talude na avenida Comendador Alfredo Maffei

Figura 20: (A) Rua no bairro Jardim das Torres, (B) rotatória do cristo 98

Figura 21: (A) Região do mercado municipal, (B) região do kartódromo. 98

Figura 22: (A) reportagem do dia 18 de fevereiro de 1967, (B) reportagem do dia 6 de fevereiro de 1973. 99

Figura 23: (A) reportagem do dia 3 de março de 2004, (B) reportagem do dia 23 de outubro de 2013. 99

Figura 24: Mapa de compartimentos geotécnicos do município de São Carlos - SP. ..... 101

Figura 25: Mapa de uso e ocupação do município de São Carlos - SP. 103

Figura 26: Mapa de declividades do município de São Carlos - SP. 105

Figura 27: Mapa de formas de encostas do município de São Carlos - SP. 107

Figura 28: Análise mensal dos eventos registrados. 108

Figura 29: Análise por períodos dos eventos registrados. 109

Figura 30: Natureza dos eventos na região e quantidades registradas. 109

Figura 31: Análise mensal dos eventos cadastrados feita separadamente. 110

Figura 32: Freqüência de todos os eventos cadastrados. 110

Figura 33: Frequiência dos tipos de eventos cadastrados. 111

Figura 34: Mapa de concentração dos movimentos de encosta em São Carlos - SP. 114

Figura 35: Mapa de concentração dos processos erosivos em São Carlos - SP .... 118

Figura 36: Mapa de concentração de colapso de solos em São Carlos - SP 
Figura 37: Mapa de concentração das enchentes/inundações em São Carlos - SP

Figura 38: Mapa de concentração dos alagamentos em São Carlos - SP

Figura 39: Precipitação média anual $(\mathrm{mm})$ para o município de São Carlos - SP (SILVA JÚNIOR 2016)

Figura 40: Evolução do CCM no ano pluviométrico de 2015 a 2016 e registro dos eventos (SILVA JUNIOR, 2016).

Figura 41: Precipitação diária, CCM e eventos registrados em novembro de 2015 (SILVA JUNIOR, 2016).

Figura 42: Precipitação diária, CCM e eventos registrados em janeiro de 2016 (SILVA JUNIOR, 2016) 



\section{LISTA DE TABELAS}

Tabela 1: Trabalhos analisados na área de estudo 43

Tabela 2: Definição dos principais termos utilizados na análise de risco (IUGS - Working Group Committee on Risk Assessment, 1997). Adaptado por AUGUSTO FILHO (2001)...47

Tabela 3: Terminologia usualmente empregada para designar os diferentes produtos cartográficos de caracterização do meio físico (CERRI, 1990).

Tabela 4: Tipos de mapas geotécnicos (BITAR et al., 1992 apud Augusto Filho, 2001).......51

Tabela 5: Feições resultantes do escoamento superficial. .54

Tabela 6: Principais características dos solos colapsíveis (Ferreira; Vilar, 2015) ...... .55

Tabela 7: Critérios de identificação de solos colapsíveis. Ferreira \& Vilar, (2015). .56

Tabela 8: Principais tipos de movimentos de massa associados a encosta (AUGUSTO FILHO, 1992).

Tabela 9: Principais materiais utilizados na pesquisa. .73

Tabela 10: Etapas, atividades da pesquisa e produtos gerado. .74

Tabela 11: Valores atribuídos para cada classe de cada mapa temático. 83

Tabela 12: Elevações presentes na área e suas respectivas áreas e porcentagens de ocupação.

Tabela 13: Ensaios de granulometria, Compartimento Botucatu. (AGUIAR, 1989; BARTOLOMEU, 2012).

Tabela 14: Ensaios de índices físicos, Compartimento Botucatu. (AGUIAR, 1989; BARTOLOMEU, 2012)

Tabela 15: Ensaios de granulometria, Compartimento Serra Geral. (AGUIAR, 1989; BARTOLOMEU, 2012) 90 
Tabela 16: Ensaios de índices físicos, Compartimento Serra Geral. (AGUIAR, 1989; BARTOLOMEU, 2012).

Tabela 17: Ensaios de granulometria, Compartimento Itaqueri. (AGUIAR, 1989; BARTOLOMEU, 2012). 90

Tabela 18: Ensaios de índices físicos, Compartimento Itaqueri. (AGUIAR, 1989; BARTOLOMEU, 2012). 91

Tabela 19: Ensaios de granulometria, Compartimento Aluvionar. (AGUIAR, 1989; BARTOLOMEU, 2012). 92

Tabela 20: : Ensaios de índices físicos, Compartimento Aluvionar. (AGUIAR, 1989; BARTOLOMEU, 2012). 92

Tabela 21: Dados dos postos pluviométricos (SILVA JÚNIOR, 2016) 93

Tabela 22: Máxima diária e médias anuais (SILVA JÚNIOR, 2016). 95

Tabela 23: Médias mensais (SILVA JÚNIOR, 2016). 95

Tabela 24: Pontos levantados nas campanhas de campo. 96

Tabela 25: Compartimentos geotécnicos e suas respectivas áreas e porcentagens de ocupação. 100

Tabela 26: Uso e ocupação e suas respectivas áreas e porcentagens de ocupação. 102

Tabela 27: Classes de declividades e suas respectivas áreas e porcentagens de ocupação. 104

Tabela 28: Formas de encostas e suas respectivas áreas e porcentagens de ocupação........ 106

Tabela 29: Índice de concentração de eventos por $\mathrm{Km}^{2}$ de cada bacia. 111

Tabela 30: Índice de concentração de movimentos de encosta para as classes de uso e ocupação.

Tabela 31: Índice de concentração de movimentos de encosta para os compartimentos geotécnicos 
Tabela 32: Índice de concentração de movimentos de encosta para as formas de encostas. 113

Tabela 33: Índice de concentração de movimentos de encosta para as classes de declividades.

Tabela 34: Quantificação de movimentos de encostas por bacias.

Tabela 35: Índice de concentração de processos erosivos para as classes de uso e ocupação.

Tabela 36: Índice de concentração de processos erosivos para os compartimentos geotécnicos.

Tabela 37: Índice de concentração de processos erosivos para as formas de encostas. 116

Tabela 38: Índice de concentração de processos erosivos para as classes de declividade....116

Tabela 39: Quantificação de processos erosivos por bacias

Tabela 40: Índice de concentração de solos colapsíveis para as classes de uso e ocupação. 119

Tabela 41: Índice de concentração de solos colapsíveis para os compartimentos geotécnicos.

Tabela 42: Grau de saturação e porosidade de amostras do compartimento itaqueri 120

Tabela 43: Índice de concentração de solos colapsíveis para as formas de encostas. 121

Tabela 44: Índice de concentração de solos colapsíveis para as classes de declividades. ....121

Tabela 45: Quantificação de colapso de solos por bacias.

Tabela 46: Índice de concentração de enchentes/inundações para as classes de uso e ocupação.

Tabela 47: Índice de concentração de enchentes/inundações para os compartimentos geotécnicos.

Tabela 48: Índice de concentração de enchentes/inundações para as formas de encostas .... 124 
Tabela 49: Índice de concentração de enchentes/inundações para as classes de declividades.

Tabela 50: Quantificação das enchentes/inundações por bacias

Tabela 51: Índice de concentração de alagamentos para as classes de uso e ocupação. ....... 126

Tabela 52: Índice de concentração de alagamentos para os compartimentos geotécnicos... 126

Tabela 53: Índice de concentração de alagamentos para as formas de encostas.

Tabela 54: Índice de concentração dos alagamentos para as classes de declividades.

Tabela 55: Quantificação dos alagamentos por bacias.

Tabela 56: Distribuição dos valores de CCM com registros de eventos e na série histórica em termos percentuais (SILVA JUNIOR, 2016).

Tabela 57: Distribuição anual dos valores de CCM na série histórica (SILVA JUNIOR, 2016).

Tabela 58: Distribuição dos valores de precipitação diária em relação aos eventos registrados e a série histórica (SILVA JUNIOR, 2016).

Tabela 59: Classes de terreno com movimentos de encosta registrados.

Tabela 60: Áreas ocupadas pelas classes de suscetibilidade a movimentos de encostas. 136

Tabela 61: Classes de terreno com erosões pluviais registradas.

Tabela 62: Áreas ocupadas pelas classes de suscetibilidade a erosões pluviais. 138

Tabela 63: Classes de terreno com colapso de solos registrados.

Tabela 64: Áreas ocupadas pelas classes de suscetibilidade a colapso de solos.

Tabela 65: Classes de terreno com enchentes/inundações registradas. 140

Tabela 66: Áreas ocupadas pelas classes de suscetibilidade a enchentes/inundações. 141 


\section{SUMÁRIO}

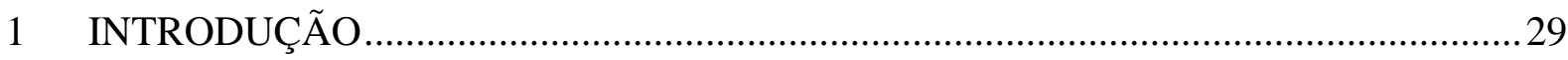

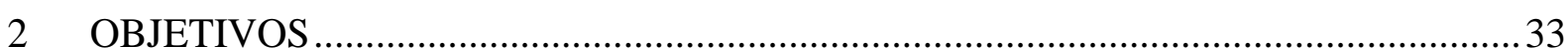

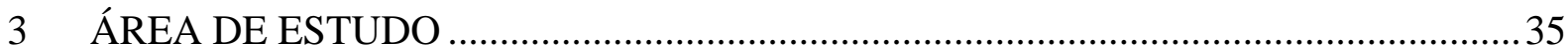

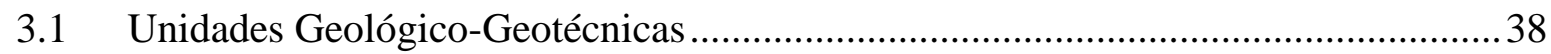

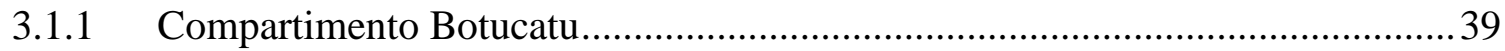

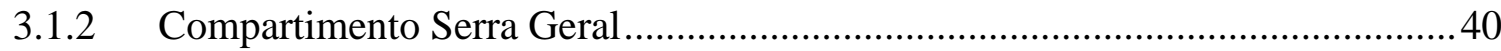

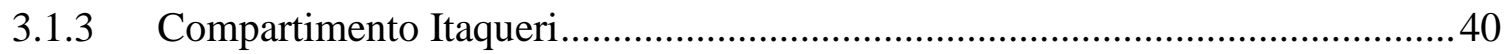

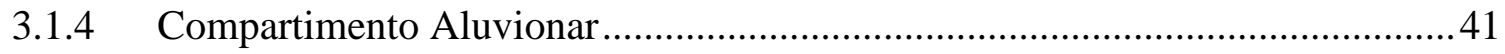

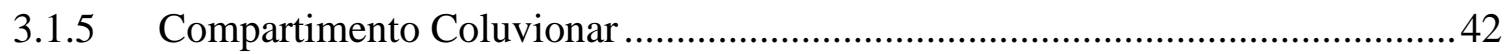

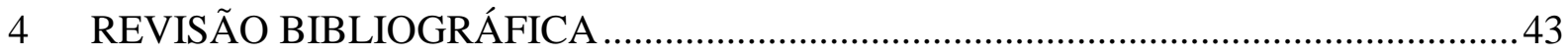

4.1 Trabalhos Anteriores na Área de Estudo Correlatos ao Tema Investigado ...............43

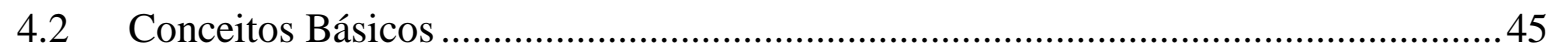

4.3 Tipos de Mapas Geotécnicos ............................................................................ 48

4.4 Eventos Perigosos de Natureza Geológica-Hidrológica em São Carlos.....................51

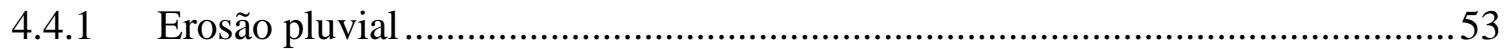

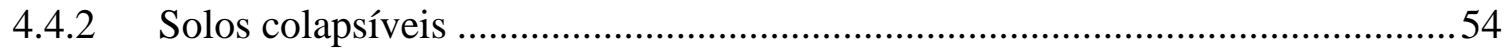

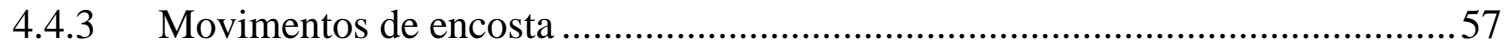

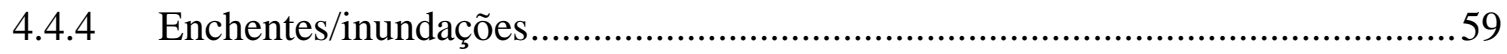

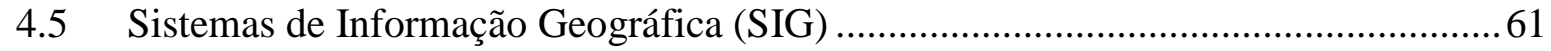

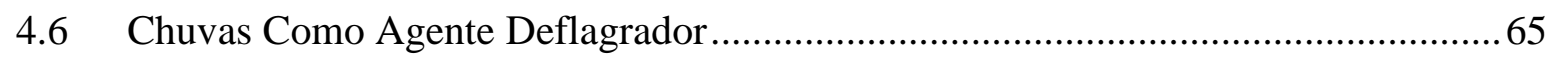

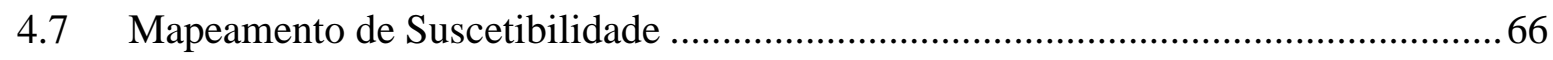

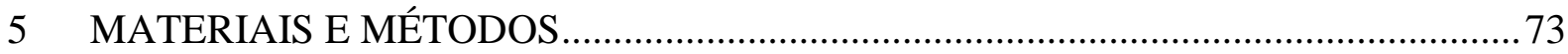

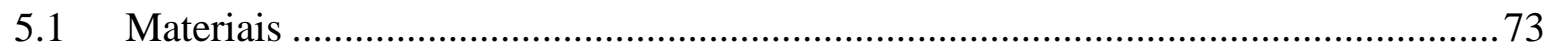

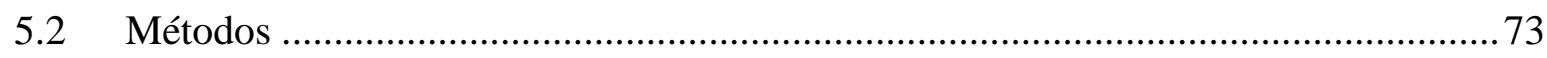

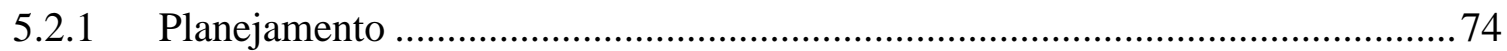

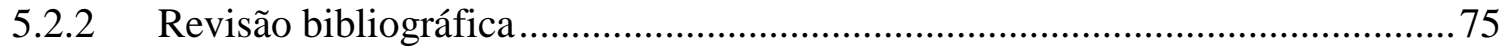


5.2.3.1 Elaboração da base cartográfica digital. ............................................... 75

5.2.3.2 Levantamento de eventos perigosos ................................................ 76

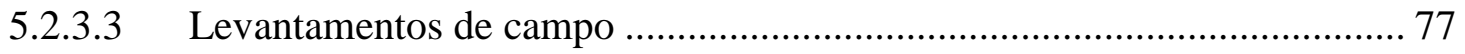

5.2.3.4 Caracterização da pluviometria ......................................................... 78

5.2.3.5 Elaboração dos mapas temáticos ........................................................ 78

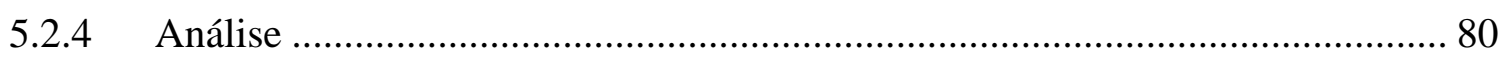

5.2.4.1 Correlação entre índice pluviométrico e eventos de enchentes/inundações,

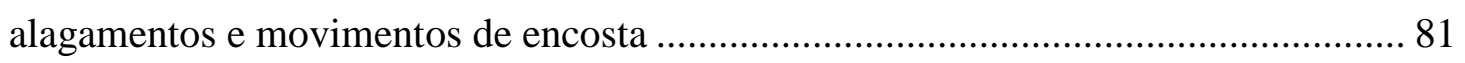

5.2.4.2 Elaboração de mapas de concentração de eventos .................................... 81

5.2.4.3 Elaboração dos mapas de suscetibilidade ............................................ 82

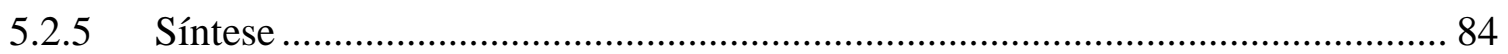

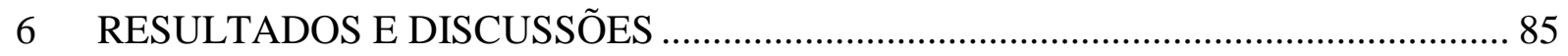

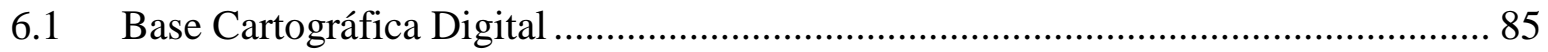

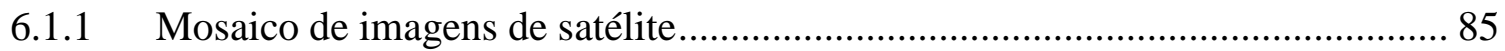

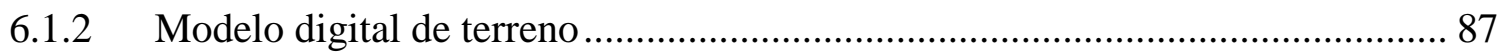

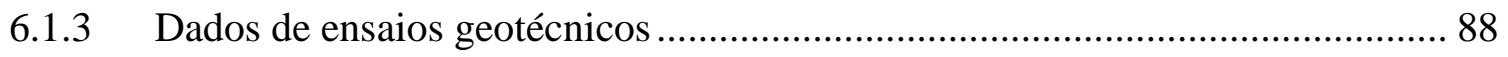

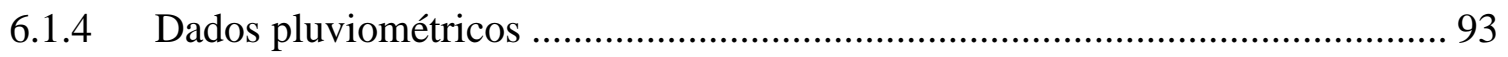

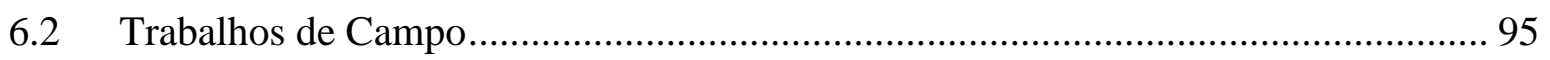

6.3 Eventos Geológicos e Hidrológicos Cadastrados................................................... 98

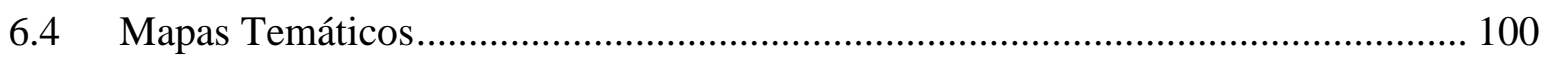

6.4.1 Compartimentos geológico-geotécnicos ................................................... 100

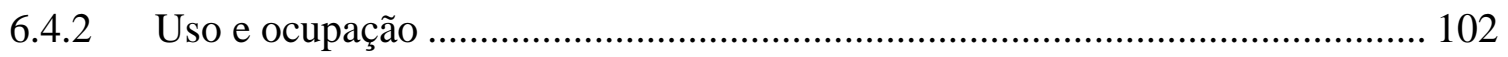

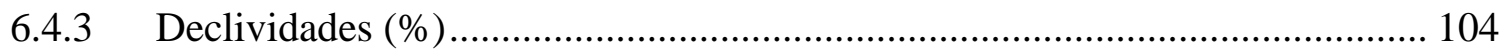

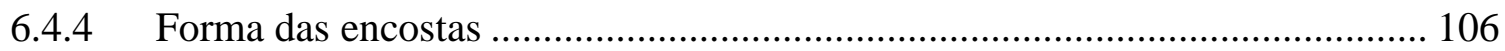

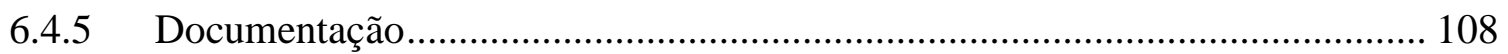

6.5 Mapas de Concentração de Eventos ..................................................................... 108 


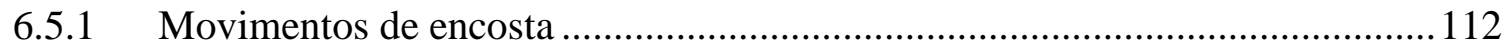

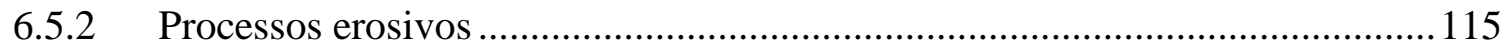

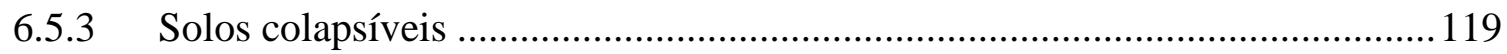

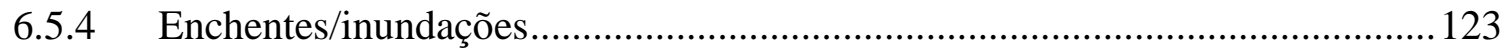

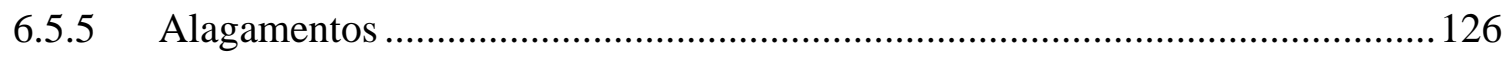

6.6 Correlação entre Índices Pluviométricos e Eventos de Enchentes/Inundações, Alagamentos e Movimentos de Encosta......................................................................... 129

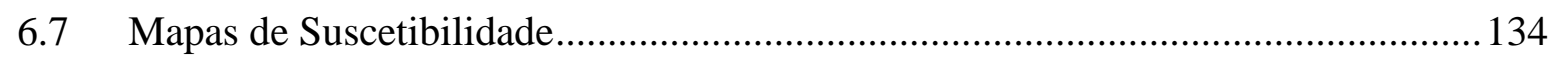

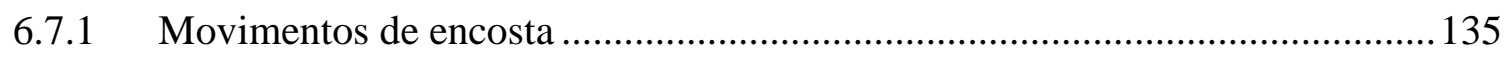

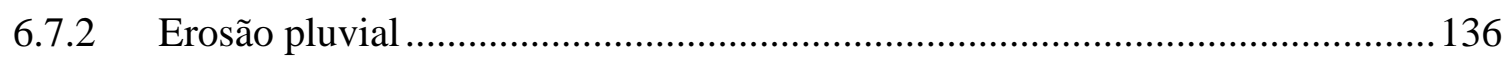

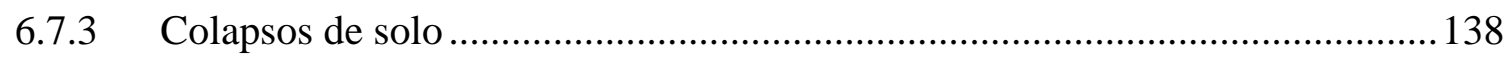

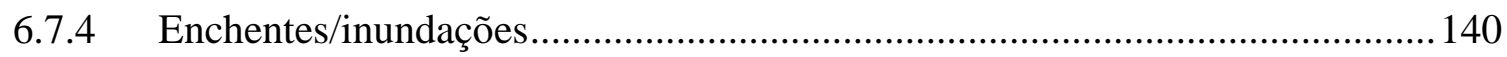

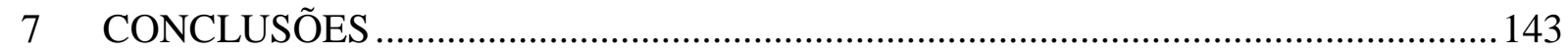

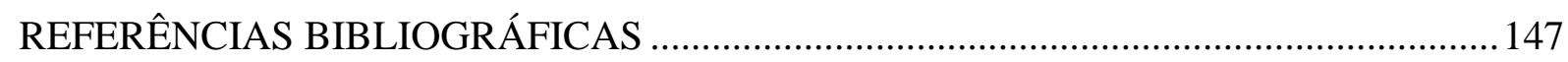

ANEXO A - Eventos correlacionados a índices pluviométricos......................................... 153

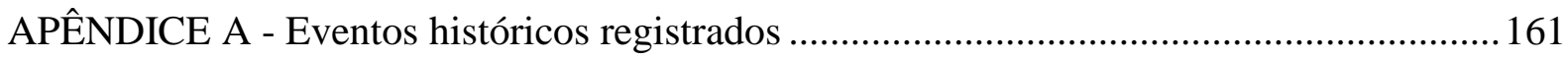

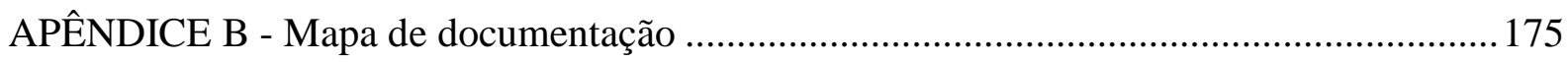

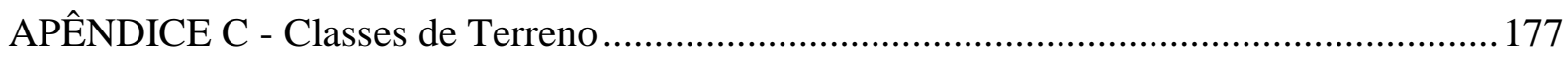

APÊNDICE D - Mapa de suscetibilidade a movimentos de encosta ................................... 187

APÊNDICE E - Mapa de suscetibilidade a erosões pluviais ............................................. 189

APÊNDICE F - Mapa de Suscetibilidade a colapso de solos............................................ 191

APÊNDICE G - Mapa de suscetibilidade a enchentes/inundações ...................................... 193 



\section{INTRODUÇÃO}

Nos dias atuais, o mapeamento dos eventos perigosos de natureza geológica e hidrológica tais como, terremotos, erosão e sedimentação, enchentes e inundações, movimentos de encosta, colapsos, entre outros, é fundamental para que se evite transtornos socioeconômicos. As consequências relacionadas a estes eventos vêm aumentando devido ao crescimento desenfreado das cidades, às atividades antrópicas e a deficiência de políticas públicas de prevenção.

De acordo com o The International Disaster Database (EM-DAT, 2016) o número de pessoas afetadas por desastres naturais no planeta vem aumentando consideravelmente, e somente nos últimos 5 anos estes números começam a mostrar uma tendência de queda (Figura 1). Segundo este banco de dados, em 2015 foram reportados 346 desastres naturais de grandes proporções nas diferentes regiões da Terra, afetando mais de 90 mil pessoas, resultando em danos econômicos da ordem de 60 bilhões de dólares e danos sociais incalculáveis. Vale ressaltar que o número real é muito maior que os apresentados, visto que muitos casos ainda não são registrados. Bell (1999), observa que três milhões de pessoas foram mortas por desastres naturais entre os anos de 1960 e 1990, porém somente $0,7 \%$ foram mortos em países desenvolvidos, evidenciando a enorme disparidade existente entre as consequências ocorridas em países subdesenvolvidos e desenvolvidos, decorrente da maior vulnerabilidade do primeiro grupo.

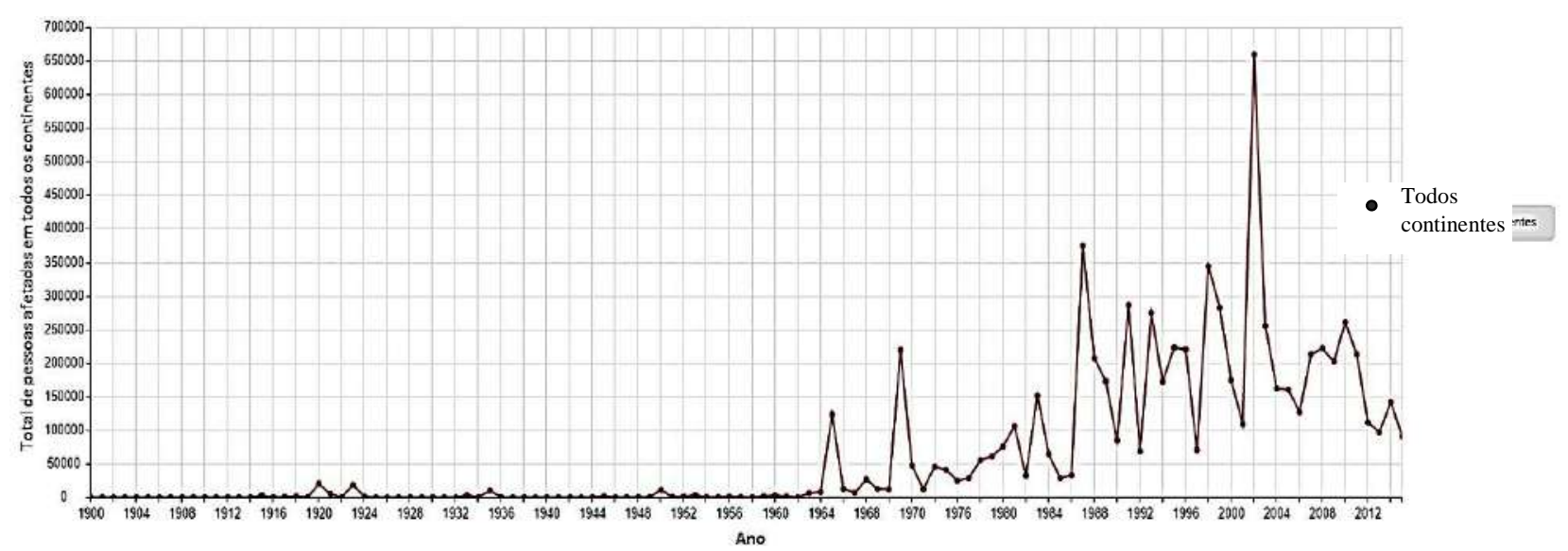

Figura 1: Número de pessoas afetadas por desastres naturais em todos os continentes (EM-DAT, 2016).

As Nações Unidas por meio da International Strategy for Disaster Reduction (UNISDR, 2004), tem focado muito na questão da vulnerabilidade, que nada mais é que um estado 
apontado pelas condições físicas, sociais, econômicas e ambientais, as quais podem acrescer a suscetibilidade de uma comunidade ao impacto de eventos perigosos.

Os processos geológicos e hidrológicos tais como, movimentos de encosta, enchentes e inundações, erosão, assoreamento, subsidências e colapsos de solo, são os maiores responsáveis pela ocorrência de acidentes no território brasileiro. Os movimentos de encosta estão relacionados a grandes danos sociais, enquanto que as enchentes/inundações se relacionam a grandes danos econômicos. O acelerado processo de urbanização ocorrido no Brasil a partir da década de 70, e a ausência de recursos e de políticas sociais adequadas, têm gerado como consequência, a ocupação de áreas geologicamente desfavoráveis (surgimento de favelas), ocasionando graves situações de risco que consequentemente afeta, sobretudo a parcela mais pobre da população (Augusto Filho, 2001).

Um evento, que demonstra os danos sociais que podem ser causados por movimentos de encosta em nosso país, foi o megadesastre da Região Serrana do estado do Rio de Janeiro, que ocorreu entre os dias 11 e 12 de janeiro de 2011, afetando principalmente as cidades de Nova Friburgo, Teresópolis e Petrópolis. Este evento, oficialmente, causou 947 mortes, com 300 desaparecimentos, mais de 50.000 desabrigados e afetando quase 1.000 .000 de pessoas (Dourado et al, 2012).

De acordo com o The International Disaster Database (EM-DAT, op. cit.), o Brasil é um dos países mais afetados por enchentes e inundações, tendo em seus registros 94 casos desastrosos, cadastrados no período de 1960 a 2015, com 4.604 mortes e mais de 12 milhões de pessoas afetadas.

Em relação à distribuição espacial, grande parte dos desastres em decorrência de eventos perigosos de natureza geológica e hidrológica acontecem nas regiões Sul e Sudeste do Brasil. Isto ocorre, pois estas regiões possuem as maiores densidades populacionais e condições ambientais que favorecem a deflagração desses processos.

Como consequência, órgãos das esferas federal, estadual e municipal vêm criando programas de planejamento e gestão para um crescimento ordenado e sustentável. O Ministério das Cidades, em seu website, disponibiliza uma cartilha de programas e ações relacionados a habitação, programas urbanos, saneamento ambiental, transporte e mobilidade e capacitação, neste documento há diretrizes referentes a prevenção e redução de riscos ambientais. Para isto, é fundamental que os municípios possuam mapas de suscetibilidade, 
perigo, risco, entre outros, para desta forma planejar melhor sua expansão e evitar que se ocupe áreas que possuam características favoráveis a ocorrência de eventos perigosos.

Infelizmente, ainda há um grande desequilíbrio entre medidas de prevenção e ações emergenciais, predominando as do segundo tipo. Segundo Veyret (2007), isto se deve ao fato que medidas de urgência possuem uma visibilidade e impacto político muito mais abrangente que, medidas preventivas de redução de risco.

Em São Carlos - SP, acontecem vários eventos perigosos de natureza geológica e hidrológica. Casos de inundações, assoreamento, erosão, solos colapsíveis e, em algumas áreas, movimentos de encosta ocorrem com certa frequência. Devido a acelerada expansão urbana, muito comum em cidades do interior brasileiro, estes eventos são intensificados, causando transtornos sociais e econômicos.

Em um trabalho preliminar, o Instituto de Pesquisas Tecnológicas - IPT (2015) apontou 8 áreas com risco de inundação na cidade, entre elas, a mais famosa é a rotatória do Cristo, e uma área de risco para movimentos de encosta. Segundo o jornal EPTV em reportagem exibida em 27/02/2015, a região do Cristo já foi alagada mais de 30 vezes desde 2005. Segundo Pons (2006), pelo menos 10 áreas da região urbana de São Carlos apresentam problemas de erosão. De acordo com Bartolomeu (2012), há uma grande probabilidade de, alguns vazamentos de postos de combustíveis terem sido condicionados por processos colapsíveis nos solos. Portanto, é importante e fundamental, o mapeamento e análise destes eventos com o objetivo de auxiliar a sua prevenção e remediação, bem como apoiar o planejamento de expansão da cidade de forma segura e sustentável.

O presente estudo foi voltado ao mapeamento da suscetibilidade a enchentes e inundações, movimentos de encosta, processos erosivos pluviais e colapsos de solo com base na análise do registro histórico destes eventos na área urbana e periurbana de São Carlos, SP. Os registros históricos foram obtidos de pesquisas em arquivos de jornais da cidade e da Defesa Civil municipal, bem como em imagens de satélite. As análises espaciais e mapas foram produzidos a partir de uma base de dados espacial na escala 1:10.000 em ambiente de SIG (Sistema de Informação Geográfica). 



\section{OBJETIVOS}

O objetivo geral do trabalho foi a elaboração de mapas de suscetibilidade a eventos perigosos de natureza geológica e hidrológica, com base na análise dos registros históricos e da distribuição espacial destes eventos na área urbana e de expansão urbana de São Carlos, SP.

As análises foram conduzidas a partir da estruturação de uma base de dados espacial na escala 1:10.000 em ambiente de Sistema de Informação Geográfica. 



\section{3 ÁREA DE ESTUDO}

São Carlos está localizado na região central do estado de São Paulo, entre as

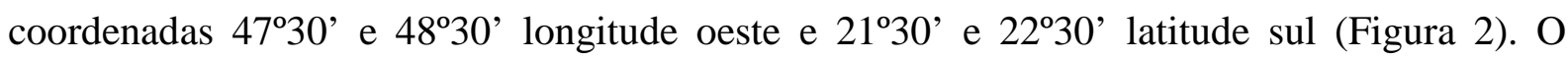
município tem uma população total de 221.950 habitantes, uma área territorial de 1.137,303 $\mathrm{Km}^{2}$ com uma densidade demográfica de 195,15 hab/Km² (IBGE, 2016). A área total de estudo possui $148,97 \mathrm{~km}^{2}$, sendo que $54,30 \mathrm{~km}^{2}$ são referentes a área urbana. Segundo Pons (2006), a urbanização em São Carlos (SP) aconteceu de forma bastante acelerada, como acontece na maioria das cidades de médio porte. É perceptível que a distribuição da população, no espaço urbano, se deu de forma desigual, acarretando no agravamento de problemas de caráter geológico e hidrológico.

Segundo levantamento do IPT (1981a), no município são encontrados Relevos de Degradação, em Planaltos Dissecados, representados por Relevo Colinoso, Relevo de Morros com Encostas Suavizadas, Relevos de Morros, Relevos Residuais suportados por litologias particulares e Relevos de Transição, representados por Encostas não Escarpadas.

No Relevo Colinoso prevalecem baixas declividades, de até $15 \%$ e amplitudes locais inferiores a 100m. Ocorrem Colinas Amplas, com topos extensos e aplainados e vertentes com perfis retilíneos a convexos, e Colinas Médias com características semelhantes, diferenciando-se apenas pela extensão dos topos.

No Relevo de Morros com Encostas Suavizadas predominam baixas declividades, de até $15 \%$ e amplitudes locais de 100 a 300m. É caracterizado por topos arredondados e achatados, e vertentes com perfis retilíneos a convexos.

No Relevo de Morros prevalecem declividades médias a altas, acima de $15 \%$ e amplitudes locais de 100 a 300m. É formado por Morros Arredondados, que exibem topos localmente achatados e vertentes com perfis convexos a retilíneos, localmente ravinadas.

No Relevo de Encostas não Escarpadas sobressaem declividades médias, entre 15 e $30 \%$ e amplitudes maiores que $100 \mathrm{~m}$. Topos angulosos e arredondados e vertentes de perfis retilíneos estão associadas a este relevo. 


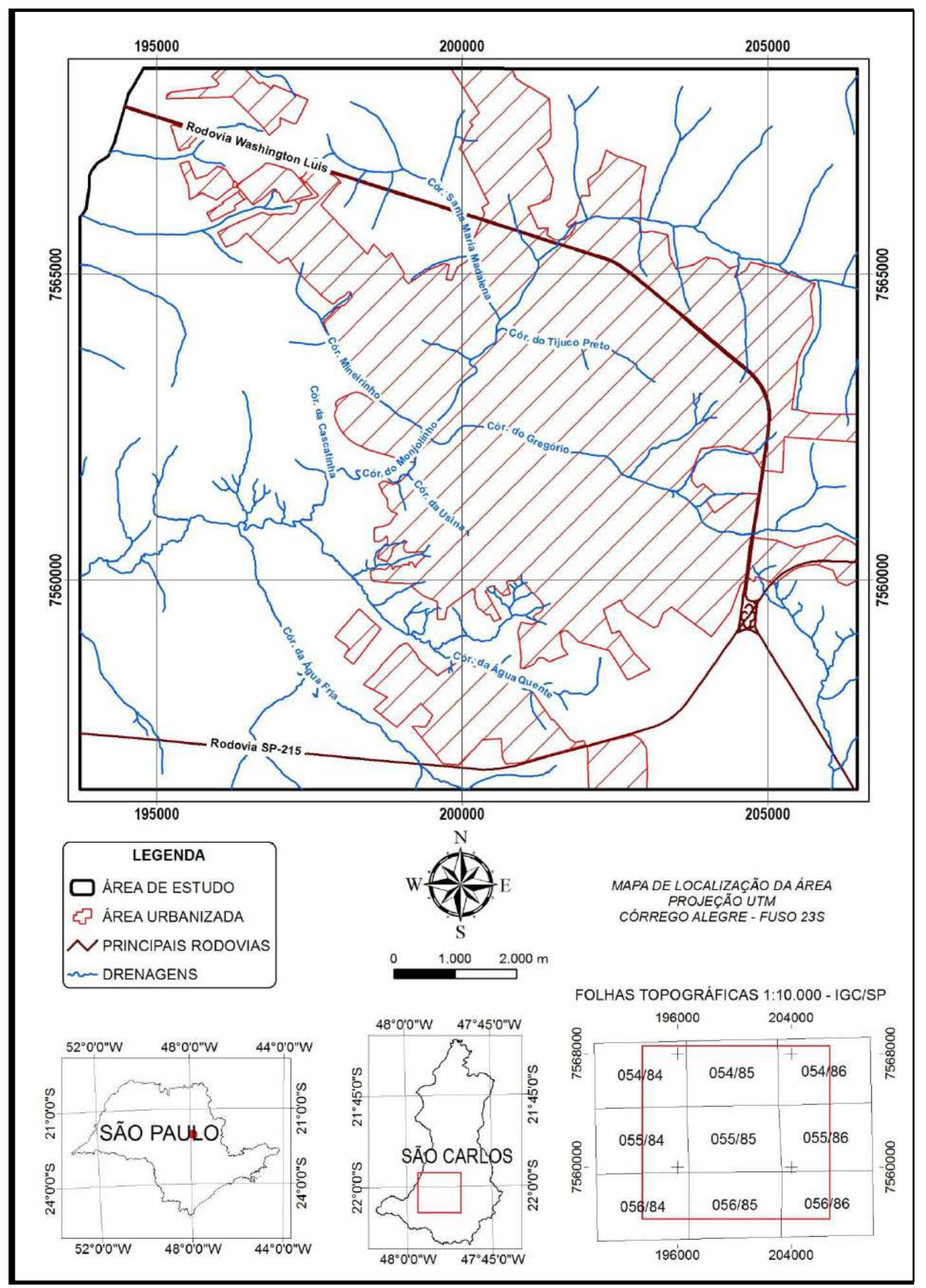

Figura 2: Área urbana de São Carlos em destaque, com a respectiva localização no estado de São Paulo, e as folhas topográficas utilizadas na pesquisa. 
Nishiyama e Zuquette (1994), caracterizam o relevo do município como grupos de encostas predominantemente suaves (declividades menores que $15^{\circ}$ ), separadas por uma zona de escarpas com declividade variando entre $45^{\circ}$ e $70^{\circ}$.

De acordo com Oliveira (1996), São Carlos localiza-se sobre o divisor de águas que limita as bacias hidrográficas do Rio Mogi-Guaçu e Tietê. Como consequência, a grande maioria dos cursos d'água que cortam São Carlos e a totalidade dos que cortam a área urbanizada, possuem suas nascentes localizadas no próprio município, o que pode ser considerado um fator favorável para a gestão dos recursos hídricos da cidade. Ocorrem na área de estudos nove córregos, a saber: Córrego Monjolinho, Água Quente, Água Fria, Gregório, Cascatinha, Mineirinho, Tijuco Preto, Usina, Santa Maria Madalena e o Rio Monjolinho.

Segundo Gonçalves (1986), a vegetação natural dominante era o cerrado, caracterizado como uma formação não florestal herbáceo-lenhosa e herbáceo arbustiva. O cerrado expõe uma fisionomia que alterna desde campo cerrado até cerradão, atingindo até 6 metros de altura, porém atualmente tem sido alterado por atividades de reflorestamento, loteamentos e mineração, sendo nos dias de hoje reduzido a algumas porções florestais, sobretudo aos arredores do bairro Cidade Aracy (Oliveira, 1996). As pastagens tomam a maior parte das terras que estão em volta do núcleo urbano, com exceção do lado oeste, em direção a Ibaté, onde ocorrem culturas de cana-de-açúcar.

Segundo Campanelli (2012), o uso predominante do solo é para o cultivo de cana de açúcar. Esta atividade ao longo do tempo foi responsável por grandes alterações no uso do solo, reduzindo sensivelmente os remanescentes de vegetação nativa (cerrado), fazendo com que os mesmos se tornassem restritos ao longo de alguns cursos d'água.

O clima em São Carlos, pela classificação Koppen é o Cwa, caracterizado por um clima temperado úmido, com verão quente, e inverno seco, tendo uma temperatura média para o mês mais frio maior que $17^{\circ} \mathrm{C}$, e para o mês mais quente maior que $22^{\circ} \mathrm{C}$ (Rolim et al. 2007). De acordo com os dados da estação D5-076, localizada na Fazenda Água Branca em São Carlos (lat -22 04' 03"; lon $-48^{\circ} 02^{\prime} 46^{\prime \prime}$ ), apresentados pelo Departamento de Águas e Energia Elétrica (DAEE, 2016), pode-se observar que os meses do verão são os mais chuvosos, com as três médias maiores ocorrendo nos meses de janeiro, dezembro e fevereiro respectivamente (Figura 3). 


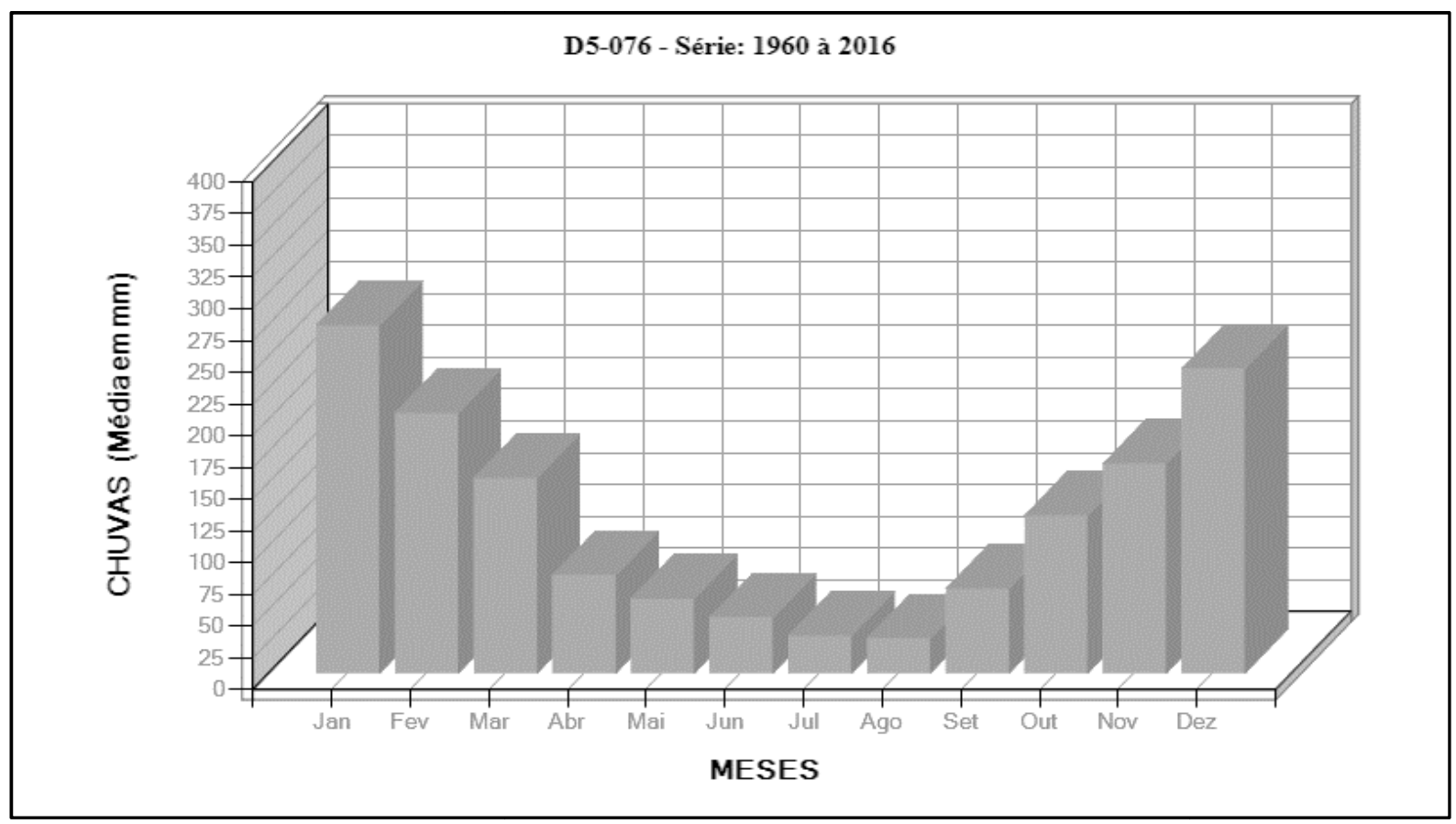

Figura 3: Média pluviométrica mensal para os anos de 1959 a 2016 (DAEE, 2016).

\subsection{Unidades Geológico-Geotécnicas}

Regionalmente, a área estudada situa-se no contexto geológico da Bacia do Paraná, trata-se de uma unidade geotectônica constituída sobre a Plataforma Sul-Americana a partir do período Siluriano, sendo considerada uma bacia intracratônica (IPT, 1981b). No Brasil compreende os territórios dos estados do Mato Grosso, Paraná, São Paulo, Santa Catarina, Rio Grande do Sul e parte dos estados de Minas Gerais e Goiás. Os principais tipos de estruturas que estão presentes na Bacia do Paraná são: falhas isoladas, sistemas lineares de falhas, horst e domos. De acordo com Soares (1973), falhas isoladas são comuns, apresentando pequena importância regional. As falhas mais comuns são normais, podendo ser observado falhas inversas também. Apesar de isoladas, alguns eventos como movimentos de encosta e erosões pluviais podem estar relacionados a presença destas falhas.

Localmente, vários autores como Zuquette (1981), Aguiar (1989), Nishiyama (1991) e Muro (2000), apresentaram mapas geológicos para a área de estudo. Foram identificadas pelos autores a Formação Botucatu, Serra Geral (basaltos) e Diabásios associados a esta formação e o Grupo Bauru. Vale ressaltar que estes mapas em geral, não cartografam estas unidades geológicas dentro dos limites da área urbana. Alguns autores, como Pons (2006) afirmam que onde ocorre o Grupo Bauru na região, trata-se na verdade da Formação Itaqueri. 
A presente pesquisa utilizará a compartimentação geológico-geotécnica realizada por Bartolomeu (2012), que foi gerada a partir de dados de trabalhos anteriores, juntamente com dados obtidos através de um mapeamento realizado pelo autor na área. A base digital elaborada por Bartolomeu (op.cit) na escala 1:10.000, também foi utilizada no presente estudo. Os critérios adotados para a subdivisão em compartimentos geológicos-geotécnicos foram determinados de acordo com os limites litológicos mapeados e os materiais inconsolidados. Foram delimitados as Formações geológicas Botucatu, Serra Geral, Itaqueri. Aluvionar e Coluvionar. Para facilitar a compreensão, nomeou-se os compartimentos respectivamente como suas formações geológicas correspondentes, ou seja, os limites geológicos-geotécnicos da Formação Serra Geral, foram nomeados como Compartimento Serra Geral, onde é tratado não somente as propriedades geológicas, mas também as características relacionadas aos materiais inconsolidados e aos atributos geotécnicos.

\subsubsection{Compartimento Botucatu}

O compartimento Botucatu está presente em uma área de 40,09 $\mathrm{km}^{2}(26,9 \%)$ e situase na porção sul da área de estudo. É caracterizada pela área aflorante da Formação de mesmo nome. A rocha presente é descrita como arenitos quartzosos com teor de finos variando normalmente de baixo a incipiente $(<15 \%)$ e geralmente foscos, há também a presença de alguns minerais máficos. Resultados de análises granulométricas mostram um nível considerável de silte (aproximadamente 18\%) em poucas amostras, enquanto o restante é constituído por areais $(\approx 80 \%)$, em sua maioria na fração fina (Aguiar, 1989). A Formação Botucatu é descrita por Milani (1997), como depósitos de grandes dunas, tendo sua gênese relacionada a processos de sedimentação eólica, com influencia fluvial na porção basal. Devido à grande quantidade da fração areia de origem eólica (granulometria bem selecionada), supõe-se que a condutividade hidráulica do compartimento seja consideravelmente elevada.

Este compartimento apresenta na área de estudo uma geomorfologia majoritariamente classificada como colinas médias. Ocorre também em vertentes de inclinação elevada na face da cuesta basáltica, que surge mais ao sul da área de estudos em contato com os basaltos da Formação Serra Geral. O compartimento Botucatu apresenta um elevado grau de alteração, no entanto isto não ocorre em algumas porções, devido a cimentação silicosa que oblitera a porosidade primária, deixando a rocha resistente ao intemperismo e pouco permeável. 


\subsubsection{Compartimento Serra Geral}

O compartimento Serra Geral é referente a área aflorante da Formação Serra Geral, que segundo Milani (1997), deriva de um intenso vulcanismo mesozóico, que gerou uma espessa cobertura de lavas basalticas de composição toleítica de até $1000 \mathrm{~m}$ e das intrusivas básicas correlatas a esta Formação. Totaliza uma área de $4,01 \mathrm{~km}^{2}(2,7 \%)$, ocupando as regiões central e oeste da área de estudo, em cotas mais elevadas que o compartimento Botucatu, situando-se nas áreas de vales dos córregos Monjolinho e Gregório principalmente e de cuestas basálticas.

As rochas que o compõe, são em sua maioria basaltos de textura afanítica fina com coloração cinza a negra. Em pequenas áreas especificas afloram alguns diques de diabásio, cuja seção visível está presente em taludes de corte, possuindo coloração semelhante a dos basaltos, com grau de alteração insipiente a médio e textura fanerítica fina a média.

Este compartimento apresenta diversos graus de alteração, desde rocha sã, representado por basaltos com disjunção colunar, alterando para um solo residual jovem ainda com características da rocha de origem, à amostras em um avançado estado de intemperismo, tendo uma coloração majoritariamente marrom. Resultados de análises granulométricas do material inconsolidado mostra um elevado teor de finos, com teores em torno de $39 \%$ da fração argila e $27 \%$ da fração silte. A fração areia fina possui teores em torno de $29 \%$, enquanto o restante é composto por uma pequena quantidade de areia grossa e pedregulho (Aguiar, 1989).

\subsubsection{Compartimento Itaqueri}

A formação Itaqueri não possui uma definição cronológica e genética clara na literatura, sendo muitas vezes confundida com depósitos do Grupo Bauru. O compartimento Itaqueri é composto por arenitos quartzosos e representa a maior área aflorante na região estudada, sendo responsável por 102,98 $\mathrm{km}^{2}(69,1 \%)$, ocupando quase toda a área urbana.

Este compartimento, aparece em cotas maiores que o compartimento Serra Geral, os materiais inconsolidados possui uma transição marcada por uma coloração escura, com tons vermelho escuro a marrom, tem um elevado índice de óxidos e feldspatos intemperizados, também apresentando quartzo imaturo. 
A feição mais frequente deste compartimento, possui textura de coloração variegada, com manchas acinzentadas em uma matriz marrom clara. Contém também camadas distintas, sendo uma camada de textura mais argilo siltosa e outra mais arenosa, ambas separadas por uma linha de seixos. Pode-se notar um elevado grau de alteração nas camadas tanto abaixo quanto acima da linha de seixos, evidenciando que a deposição ocorreu a um tempo considerável, e em seguida o pacote sedimentar sofreu alteração.

Resultados de análises granulométricas do material inconsolidado mostram um considerável teor de finos, com teores em torno de $29 \%$ da fração argila e $14 \%$ da fração silte. A fração areia fina possui proporções em torno de $44 \%$, enquanto o restante é composto por uma pequena quantidade de areia média e grossa (Aguiar, 1989).

\subsubsection{Compartimento Aluvionar}

O compartimento Aluvionar aparece cartografado na região sul da área estudada, associado as planícies de inundação do rio Monjolinho, com uma área de $1,05 \mathrm{~km}^{2}$ (0,7\%), é constituído predominantemente por material de textura argilo-arenosa e saturada. A textura arenosa é predominantemente composta por grãos de quartzo, com coloração amarelada, por vezes cinza clara. Os grãos de areia apresentam-se tanto pouco retrabalhados, como com um bom arredondamento e esfericidade, indicando que o material deve possuir duas áreas fontes distintas principais.

Os grãos com boa esfericidade e arredondamento, são provenientes da Formação Botucatu, onde o aluvião se insere, e os grãos imaturos decorrem da Formação Itaqueri, que está estratigraficamente acima e abriga várias nascentes que são tributárias do rio Monjolinho.

Segundo Pons (2006), este compartimento tem ocorrência limitada na área, e é composto por materiais arenosos, argilosos, e siltosos de deposição recente, restrita as planícies aluvionares.

Resultados de análises granulométricas mostra um teor de finos elevado (> 50\%). A fração areia fina possui teores em torno de $30 \%$, enquanto o restante é composto por uma pequena quantidade de areia média a grossa e pedregulhos (Aguiar, 1989). 


\subsubsection{Compartimento Coluvionar}

O compartimento Coluvionar, apresenta uma área cartografada de $0,84 \mathrm{~km}^{2}(0,6 \%)$, e foi originado por movimentos de encosta nas cuestas basálticas. Os afloramentos apresentam morfologia típica de leque coluvial e são observados em vários pontos, ao longo da linha de cuesta basáltica. Este compartimento estratigraficamente, está sobre os arenitos da Formação Botucatu, onde a contribuição deste material é visível. No entanto, as características texturais são semelhantes as areias da Formação Itaqueri.

Este compartimento é composto por grãos de quartzo foscos e bem arredondados referentes a Formação Botucatu e grãos de quartzo relacionados a Formação Itaqueri. É possível observar também um teor considerável de óxidos relacionados a Formação Serra Geral, que por possuir um padrão facetado, evidencia que o material teve um curto transporte.

Segundo Pons (2006), os materiais desta unidade são derivados das encostas de basalto onde ocorre a mistura com areias relacionadas à alteração da Formação Botucatu. São áreas de instabilidade originadas por diversos fatores, como as declividades acentuadas e a heterogeneidade do material. 


\section{REVISÃO BIBLIOGRÁFICA}

\subsection{Trabalhos Anteriores na Área de Estudo Correlatos ao Tema Investigado}

Buscou-se primeiramente revisar os trabalhos realizados na área de estudo referentes aos temas desta pesquisa, a Tabela 1 apresenta os trabalhos que foram analisados e os respectivos assuntos.

Tabela 1: Trabalhos analisados na área de estudo.

\begin{tabular}{|c|c|c|c|c|}
\hline AUTOR & TIPO & TÍTULO DO TRABALHO & ANO & ASSUNTO \\
\hline $\begin{array}{l}\text { Lázaro Valentin } \\
\text { Zuquette }\end{array}$ & Mestrado & $\begin{array}{l}\text { Mapeamento geotécnico preliminar } \\
\text { na região de São Carlos. }\end{array}$ & 1981 & $\begin{array}{l}\text { Mapeamento } \\
\text { geotécnico }\end{array}$ \\
\hline $\begin{array}{l}\text { Antonio Airton } \\
\text { Bortolucci }\end{array}$ & Mestrado & $\begin{array}{c}\text { Caracterização geológico-geotécnica } \\
\text { da região urbana de São Carlos-SP, a } \\
\text { partir de sondagens de simples } \\
\text { reconhecimento }\end{array}$ & 1983 & $\begin{array}{l}\text { Caracterização } \\
\text { geológica-geotécnica }\end{array}$ \\
\hline Marilza das Neves & Mestrado & $\begin{array}{l}\text { Estudo da permeabilidade do solo } \\
\text { colapsível da região de São Carlos. }\end{array}$ & 1987 & Solos colapsíveis \\
\hline René Levy Aguiar & Mestrado & $\begin{array}{l}\text { Mapeamento geotécnico da área de } \\
\text { expansão urbana de São Carlos-SP: } \\
\text { contribuição ao planejamento. }\end{array}$ & 1989 & $\begin{array}{l}\text { Mapeamento } \\
\text { geotécnico }\end{array}$ \\
\hline Luiz Nishiyama & Mestrado & $\begin{array}{l}\text { Mapeamento geotécnico preliminar } \\
\text { da quadricula de São Carlos - SP. }\end{array}$ & 1991 & $\begin{array}{l}\text { Mapeamento } \\
\text { geotécnico }\end{array}$ \\
\hline $\begin{array}{c}\text { René Levy } \\
\text { Aguiar/Nilson } \\
\text { Gandolfi/Antenor } \\
\text { Braga Paraguassu }\end{array}$ & $\begin{array}{l}\text { Trabalho de } \\
\text { evento }\end{array}$ & $\begin{array}{c}\text { Considerações gerais sobre a carta de } \\
\text { potencial a erosão da região de São } \\
\text { Carlos-SP. }\end{array}$ & 1995 & Erosão \\
\hline $\begin{array}{l}\text { José Augusto de } \\
\text { Lollo/ Lázaro } \\
\text { Valentin Zuquette }\end{array}$ & Artigo & $\begin{array}{l}\text { Técnica de avaliação do terreno e } \\
\text { suas possibilidades de aplicação no } \\
\text { mapeamento geotécnico : exemplo de } \\
\text { um sistema de terreno identificado na } \\
\text { região de São Carlos (SP). }\end{array}$ & 1996 & $\begin{array}{l}\text { Mapeamento } \\
\text { geotécnico }\end{array}$ \\
\hline $\begin{array}{l}\text { Benedito José } \\
\text { Imbiriba Carneiro }\end{array}$ & Doutorado & $\begin{array}{l}\text { Comportamento de tubulões à céu } \\
\text { aberto, instrumentados, em solo não- } \\
\text { saturado, colapsível }\end{array}$ & 1999 & Solos colapsíveis \\
\hline $\begin{array}{l}\text { Marcos Fernando } \\
\text { Macacari }\end{array}$ & Mestrado & $\begin{array}{l}\text { Variação da capacidade de carga com } \\
\text { a sucção e profundidade em ensaios } \\
\text { de placa em solo colapsível. }\end{array}$ & 2001 & Solos colapsíveis \\
\hline $\begin{array}{c}\text { Cristina de } \\
\text { Hollanda Cavalcanti } \\
\text { Tsuha }\end{array}$ & Mestrado & $\begin{array}{l}\text { Utilização de penetrômetro manual } \\
\text { em solo colapsível e comparação } \\
\text { com resultados de provas de carga } \\
\text { em placa e em sapata }\end{array}$ & 2003 & Solos colapsíveis \\
\hline
\end{tabular}


Continuação - Tabela 1: Trabalhos analisados na área de estudo.

\begin{tabular}{|c|c|c|c|c|}
\hline AUTOR & TIPO & TÍTULO DO TRABALHO & ANO & ASSUNTO \\
\hline $\begin{array}{c}\text { Regina Mambeli } \\
\text { Barros }\end{array}$ & Doutorado & $\begin{array}{c}\text { Previsão de enchentes para o plano } \\
\text { diretor de drenagem urbana de São } \\
\text { Carlos (PDDUSC) na bacia escola do } \\
\text { córrego do Gregório }\end{array}$ & 2005 & Inundação \\
\hline $\begin{array}{c}\text { Nívea Adriana Dias } \\
\text { Pons }\end{array}$ & Doutorado & $\begin{array}{l}\text { Levantamento e diagnóstico } \\
\text { geológico-geotécnico de áreas } \\
\text { degradadas na cidade de São Carlos - } \\
\text { SP, com auxílio de } \\
\text { geoprocessamento }\end{array}$ & 2006 & $\begin{array}{c}\text { Proposta metodológica } \\
\text { - Levantamento e } \\
\text { diagnóstico geológico } \\
\text { e geotécnicos de áreas } \\
\text { degradadas }\end{array}$ \\
\hline Regiane Veloso & Mestrado & $\begin{array}{l}\text { Caracterização geológico-geotécnica } \\
\text { do lixão desativado de São Carlos- } \\
\text { SP, com auxílio da geofísica }\end{array}$ & 2006 & $\begin{array}{c}\text { Caracterização } \\
\text { geológico-geotécnica }\end{array}$ \\
\hline $\begin{array}{c}\text { Diogo Martino } \\
\text { Fernandes Almeida }\end{array}$ & Monografia & $\begin{array}{l}\text { Sistema de gestão de risco de } \\
\text { inundações urbanas } \\
\text { baseado em web mapping. }\end{array}$ & 2010 & Inundação \\
\hline $\begin{array}{l}\text { Melissa Cristina } \\
\text { Pereira Graciosa }\end{array}$ & Doutorado & $\begin{array}{c}\text { Modelo de seguro para riscos } \\
\text { hidrológicos com base em simulação } \\
\text { hidráulico hidrológica } \\
\text { como ferramenta de gestão do risco } \\
\text { de inundações }\end{array}$ & 2010 & Inundação \\
\hline $\begin{array}{c}\text { Júnio René Toledo } \\
\text { Fagundes }\end{array}$ & Doutorado & $\begin{array}{l}\text { Estudo integrado das características } \\
\text { geológico-geotécnicas com vista à } \\
\text { avaliação de recarga de aquífero: } \\
\text { região de São Carlos-SP }\end{array}$ & 2010 & $\begin{array}{l}\text { Caracterização } \\
\text { geológico-geotécnica }\end{array}$ \\
\hline Daniel Bartolomeu & Mestrado & $\begin{array}{l}\text { Análise da vulnerabilidade dos } \\
\text { recursos hídricos na região urbana de } \\
\text { São Carlos (SP) por vazamento em } \\
\text { postos de combustíveis, utilizando o } \\
\text { método GOD e avaliação dos } \\
\text { condicionantes geotécnicos }\end{array}$ & 2012 & $\begin{array}{l}\text { Vulnerabilidade dos } \\
\text { recursos hídricos }\end{array}$ \\
\hline $\begin{array}{l}\text { Thiago Galvão } \\
\text { Tiradentes Decina }\end{array}$ & Mestrado & $\begin{array}{l}\text { Análise de medidas de controle de } \\
\text { inundações a partir da avaliação de } \\
\text { cenários de uso e ocupação do solo } \\
\text { na bacia hidrográfica do córrego do } \\
\text { Gregório, São Carlos - SP }\end{array}$ & 2012 & Inundação \\
\hline $\begin{array}{l}\text { Henrique Taveira } \\
\text { Pio }\end{array}$ & Monografia & $\begin{array}{c}\text { Estudo da precipitação e índices de } \\
\text { extremos climáticos na região de São } \\
\text { Carlos - SP }\end{array}$ & 2012 & Precipitação \\
\hline Liz Abreu Denúbila & Mestrado & $\begin{array}{l}\text { Alterações ambientais associadas à } \\
\text { mineração no município de São } \\
\text { Carlos (SP), utilizando AHP e SIG }\end{array}$ & 2013 & Erosão \\
\hline
\end{tabular}

Como pode ser observado na Tabela 1, os trabalhos tratando de inundação e mapeamento são os mais frequentes. As enchentes, inundações e alagamentos, são os eventos perigosos que mais causam transtornos para a cidade, dentre estes estudos, destaca-se o de Barros (2005) e Graciosa (2010). Em relação a erosão, pode-se destacar o trabalho de Denúblia (2013), que gerou um mapa de suscetibilidade à erosão pluvial para todo o 
município na escala 1:100.000. A análise de movimentos de encosta, é pouco frequente, consequência do relevo da cidade de São Carlos, normalmente este assunto é abordado superficialmente, nos estudos de mapeamento geotécnico. Quanto aos solos colapsíveis, a maioria dos trabalhos são relacionados a ensaios de laboratório, para análise do seu comportamento em fundações.

\subsection{Conceitos Básicos}

Inicialmente, é importante entender o que são riscos de natureza Geológica e Hidrológica. Cerri (1993) apud Augusto Filho (2001), apresenta uma classificação abrangente de riscos ambientais, que incluiu entre estes, os de origem hidrológica e geológica (Figura 4).

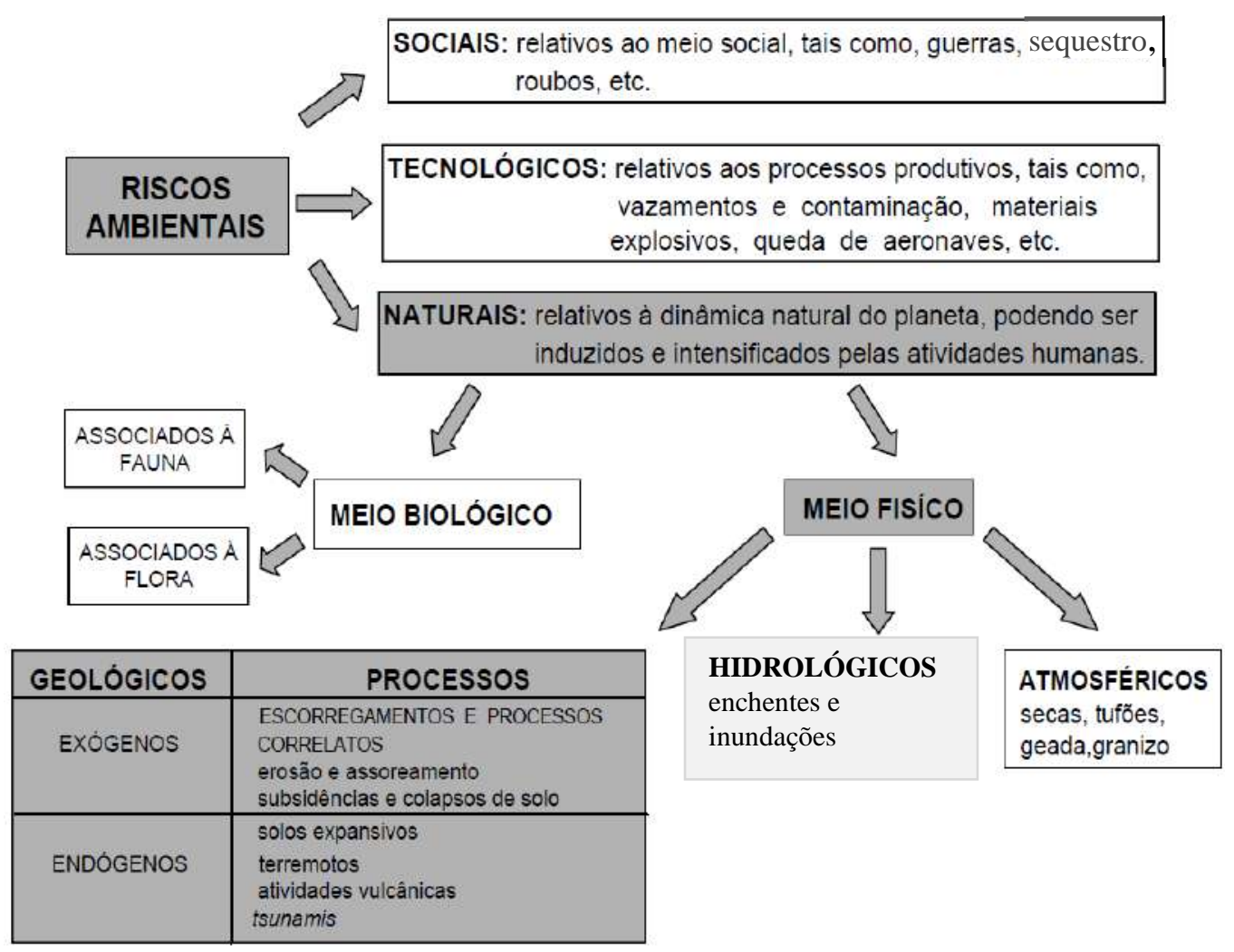

Figura 4: Principais tipos de riscos ambientais com destaque para os de natureza geológica e hidrológica (Cerri 1993 apud Augusto Filho 2001).

Para melhor compreensão, alguns conceitos que são relacionados ao estudo destes eventos devem ser definidos. $\mathrm{O}$ acontecimento em que não foram registradas perdas sociais e econômicas (inundação em área não habitada) é definido como evento, o acontecimento em que ocorre perdas sociais e econômicas (inundação em área habitada) é definido por acidente 
(Zuquette, 1993). Portanto, o termo evento perigoso é utilizado na presente pesquisa para se referir a eventos de natureza geológica e hidrológica que ocorrem na cidade e têm o potencial de gerar perdas sociais e econômicas.

Quando uma área apresenta propriedades que tendem a favorecer a ocorrência de eventos perigosos, devido a suas características como o relevo, interferências antrópicas e regime de chuvas, esta região pode ser considerada suscetível a este tipo de evento, independentemente da previsão ou probabilidade para tal ocorrência, ou seja, a área tem suscetibilidade para que ocorra um evento perigoso.

Segundo Parise (2001), suscetibilidade é a capacidade de uma área à ocorrência de eventos perigosos em relação as condições locais do terreno, onde a probabilidade não é considerada. Para Fell (2008), suscetibilidade é uma análise qualitativa ou quantitativa de classificar a área e a distribuição espacial de eventos perigosos que possuem o potencial para ocorrer em determinada região. Apesar de se esperar que um evento perigoso ocorra mais frequentemente nas áreas mais suscetíveis, isto nem sempre pode ocorrer, visto que em estudos de suscetibilidade a variável tempo não é levada em conta. Sobreira e Souza (2012), afirmam que o termo suscetibilidade pode ser interpretado como a potencialidade de processos geológicos e hidrológicos acarretarem alterações no meio físico.

Em relação as pessoas que vivem nas cidades e as estruturas existentes, quando estas estão expostas a um possível evento perigoso, se diz que estas possuem uma certa vulnerabilidade ao evento. De acordo com Augusto Filho (2001), o termo vulnerabilidade está relacionado ao elemento ou sistema sob perigo (população e estruturas) sendo utilizado como um indicador da magnitude das possíveis consequências, no caso da ocorrência do evento perigoso. Segundo Zuquette (1993) e Fell (2008), vulnerabilidade é o grau de perda esperado para um certo elemento ou elementos dentro da área afetada pelo evento perigoso, sendo expressa em uma escala de 0 (sem perda) 1 (perda total). Portanto, é de se esperar que a vulnerabilidade para um certo evento aumentará em eventos catastróficos, visto que estes acarretarão em uma maior perda econômica e social.

Segundo o IUGS - Working Group Committee On Risk Assessment (1997), perigo é uma condição com potencial para gerar um dano desagradável, deve-se incluir em uma análise de perigo, características como, área afetada e a probabilidade de ocorrência em um dado período de tempo. De acordo com Smith (2004), o termo perigo é melhor descrito como sendo uma ocorrência natural, ou induzida pelo homem, com o potencial de gerar perdas. Para 
Fell (2008) e Macedo \& Bressani (2013), perigo é uma condição com um potencial para gerar uma consequência indesejável.

Zuquette (1993), afirma que risco é uma expressão do perigo em termos de danos/período de tempo por unidade monetária/ano. Segundo o Working Group Committee On Risk Assessment (op. cit.), risco é uma medida da probabilidade e severidade de um efeito adverso para o ambiente. Risco é geralmente estimado pelo produto entre a probabilidade e as consequências. Pode-se afirmar, portanto, que a análise de risco, está sujeita a obtenção e avaliação de dois parâmetros: a probabilidade de um fenômeno ocorrer e a grandeza das consequências socioeconômicas associadas a este fenômeno (Augusto Filho, 2001).

Deve-se observar que uma avaliação de suscetibilidade, perigo e risco, é um estudo onde a complexidade aumenta gradualmente respectivamente. É necessário tomar grande cuidado com os termos que são utilizados, é bastante comum observar na literatura, trabalhos conceituados utilizando o termo "risco" para estudos que se quer utilizam dados de probabilidade. Um trabalho de risco é de grande complexidade, onde deve-se levar em conta vários fatores, e envolve várias áreas de atuação.

O Working Group Committee on Risk Assessment (op. cit.) reconhece que existe uma gama de definições relacionadas ao estudo de eventos perigosos, e expõe uma sugestão de conceituação no intuito de padronizar as definições. Esta proposta terminológica foi empregada como referência básica no comitê de avaliação de risco para escorregamentos, em encontro técnico realizado em Honolulu, em 1997. No entanto, o próprio comitê reconhece que os termos ainda não são uma unanimidade, exigindo mais trabalho e discussão para alcançar definições universais. A Tabela 2 apresenta um resumo de parte das principais definições propostas por este grupo de estudo. Vale ressaltar que apesar desta proposta ser para movimentos de encosta, esta pode ser totalmente aplicada aos outros eventos geológicos e aos hidrológicos também.

Tabela 2: Definição dos principais termos utilizados na análise de risco (IUGS - Working Group Committee on Risk Assessment, 1997). Adaptado por Augusto Filho (2001).

\begin{tabular}{c|l}
\hline \multirow{2}{*}{ TERMO } & \multicolumn{1}{c}{ DEFINIÇÃO } \\
\hline Risco (risk) & $\begin{array}{l}\text { Uma medida da probabilidade e severidade de um efeito adverso para a saúde, propriedade ou } \\
\text { ambiente. Risco é geralmente estimado pelo produto entre a probabilidade e as } \\
\text { conseqüências. Entretanto, a interpretação mais genérica de risco envolve a comparação da } \\
\text { probabilidade e consequências, não utilizando o produto matemático entre estes dois termos, } \\
\text { para expressar os níveis de risco. }\end{array}$ \\
\hline
\end{tabular}


Continuação Tabela 2: Definição dos principais termos utilizados na análise de risco (IUGS Working Group Committee on Risk Assessment, 1997). Adaptado por Augusto Filho (2001).

\begin{tabular}{c|l}
\hline TERMO & \multicolumn{1}{c}{ DEFINIÇÃo } \\
\hline Processo perigoso (danger) & $\begin{array}{l}\text { O fenômeno natural geometricamente e mecanicamente caracterizado (no caso, os fenômenos } \\
\text { naturais seriam os diferentes tipos de eventos perigosos). }\end{array}$ \\
\hline Perigo (hazard) & $\begin{array}{l}\text { Uma condição com potencial para causar uma consequência desagradável. Alternativamente, o } \\
\text { perigo é a probabilidade de um evento perigoso ocorrer num dado período de tempo. }\end{array}$ \\
\hline $\begin{array}{c}\text { Elementos sob risco } \\
\text { (elements at risk) }\end{array}$ & $\begin{array}{l}\text { A população, as edificações e as obras de engenharia, as atividades econômicas, } \\
\text { os serviços públicos e a infra-estrutura na área potencialmente afetável pelos eventos perigosos. }\end{array}$ \\
\hline $\begin{array}{c}\text { Probabilidade }-\mathrm{P} \\
\text { (probability) }\end{array}$ & $\begin{array}{l}\text { A probabilidade de um resultado específico, medido pela razão entre o número de resultados } \\
\text { específicos e todos os resultados possíveis. A probabilidade é expressa como um número } \\
\text { entre 0 e 1, com 0 indicando um resultado impossível, e 1 indicando que um resultado é certo. }\end{array}$ \\
\hline $\begin{array}{c}\text { Vunerabilidade }-\mathrm{V} \\
\text { (vulnerability) }\end{array}$ & $\begin{array}{l}\text { O grau de perda para um dado elemento ou grupo de elementos dentro de um área afetada por } \\
\text { eventos perigosos. Ela é expressa em uma escala de 0 (sem perda) a 1 (perda total). Para } \\
\text { propriedades, a perda será o valor da edificação; para pessoas, ela será a probabilidade de } \\
\text { que uma vida seja perdida, em um determinado grupo humano que pode ser afetado pelos } \\
\text { eventos. }\end{array}$ \\
\hline
\end{tabular}

\subsection{Tipos de Mapas Geotécnicos}

Primeiramente é importante diferenciar os termos mapa e carta, Oliveira (1983) aconselha o uso do termo carta para documentos cartográficos que apresenta uma maior confiança no que diz respeito a precisão das informações. Por outro lado o termo mapa, não necessariamente apresenta esta precisão, sendo assim documentos menos rigorosos em relação aos dados utilizados. Para Zuquette e Nakazawa (1998), o termo mapa, deve ser empregado para os documentos cuja informações registradas, são obtidas de um determinado meio físico, sem que haja necessariamente uma interpretação crítica dessas informações, carta é o documento que contém estas interpretações para um intuito específico. No presente trabalho se utilizará o termo mapa para todos os produtos cartográficos produzidos pelo estudo.

Segundo Zuquette (1993), mapeamento geotécnico é o conjunto de processos que procura investigar e avaliar as características do meio físico, com o objetivo de orientar o planejamento e ocupação de determinada região, de forma a auxiliar na prevenção de problemas em andamento e na prevenção de problemas posteriores.

O mapeamento de eventos perigosos prevê primeiramente a elaboração de mapas básicos, para depois poder gerar mapas interpretativos como os de suscetibilidade, perigo, risco, entre outros. A Tabela 3, apresenta a terminologia frequentemente empregada para definir os diferentes tipos de mapas utilizados para a caracterização do meio físico. 
Tabela 3: Terminologia usualmente empregada para designar os diferentes produtos cartográficos de caracterização do meio físico (Cerri, 1990).

\begin{tabular}{|c|c|c|}
\hline INFORMAÇÕES BÁSICAS & PRODUTO INTERMEDIÁRIO & PRODUTO FINAL \\
\hline $\begin{array}{l}\text { Mapas temáticos } \\
\text { Mapas analíticos } \\
\text { Mapas básicos }\end{array}$ & $\begin{array}{l}\text { Mapas derivados } \\
\text { Mapas interpretativos } \\
\text { Mapas de síntese }\end{array}$ & $\begin{array}{l}\text { Cartas geotécnicas } \\
\text { Mapas geotécnicos } \\
\text { Cartas de planejamento regional } \\
\text { Cartas geo-ambientais } \\
\text { Mapas de zoneamento ambiental } \\
\text { Mapas de zoneamento geotécnico } \\
\text { Mapas de zoneamento urbano } \\
\text { Mapas de aptidão } \\
\text { Cartas de vulnerabilidade } \\
\text { Mapas de potencial natural } \\
\text { Mapas de } 1^{\mathrm{a}}, 2^{\mathrm{a}}, 3^{\mathrm{a}} \ldots \text { ordens } \\
\text { Cartas de risco } \\
\text { Zoneamento de risco }\end{array}$ \\
\hline
\end{tabular}

Segundo Pejon e Ferreira (2015), algumas informações do meio físico são imprescindíveis e básicas para qualquer estudo onde se queira gerar mapas interpretativos, enquanto outras específicas serão consideradas dependendo do intuito e dos objetivos do mapeamento. Alguns mapas básicos serão descritos a seguir.

\section{Mapa de documentação}

São informações fundamentais para a gestão da informação sobre a área de estudo e necessitam conter o registro cartográfico de informações precisas, como os pontos de amostragem, descrição de afloramentos entre outros. Esse documento tem como apoio o mapa topográfico com as curvas de nível, estradas, drenagens e pontos cotados, as vezes pode ainda conter a malha urbana do município.

\section{Mapa geológico, litológico ou do substrato rochoso}

São informações que tem por finalidade descrever as rochas sãs que ocorrem em certa área/zona. Um mapa geológico clássico traz um conjunto de informações referentes ás rochas (litologia), estrutura, descontinuidades entre outras características. Quanto ao substrato rochoso, além das informações já descritas, são normalmente incluídas algumas específicas, como: mineralogia, densidade e porosidade aparentes, níveis de intemperismo, potencial de alteração, condutividade hidráulica e resistência. 


\section{Mapas de Solos ou materiais inconsolidados}

O termo materiais inconsolidados, é o mais utilizado na Geotecnia, pois considera os materiais geológicos naturais (residuais e retrabalhados) que se localizam sobre o substrato rochoso pouco alterado até a superfície. Esses pacotes podem alcançar mais de 100 metros em regiões equatoriais, sendo que no Sudeste podem ter espessuras maiores que 50 metros.

\section{Mapas das classes de declividades}

Este mapa tem por finalidade quantificar a inclinação ou o declive do terreno, apresentando esse valor em porcentagem ou graus, em relação a um plano horizontal. É uma representação cartográfica de muita relevância em um estudo de eventos perigosos, visto que o manejo de áreas rurais e o gerenciamento do uso do solo urbano precisam de dados referentes a declividade. Muitos processos geológicos e hidrológicos ocorrem em consequência da existência de determinadas inclinações do terreno, como erosão, assoreamento, movimentos de encosta, inundações, entre outros.

\section{Mapas geomorfológicos ou de formas do terreno}

É um componente fundamental para algumas analises, como suscetibilidade e perigo, a forma do terreno, influencia alguns dos processos geológicos e hidrológicos e o planejamento do uso e ocupação. Existem diversos documentos que podem servir para análise desse fim, como mapas geomorfológicos, análise por forma de terreno, landform e análise por bacias ou encostas. Existem vários outros tipos de mapas básicos/temáticos, para cada tipo de análise, é necessário definir quais destes mapas serão fundamentais para o andamento do estudo.

Bittar et al. (1992) apud Augusto Filho (2001) exemplifica na Tabela 4 os mapas geotécnicos que podem ser gerados a partir de um estudo de eventos perigosos. Einstein (1988), sugere um procedimento de avaliação de risco de eventos perigosos em uma estrutura de 5 níveis de mapeamento:

Nível 1 - Mapas de Estado da Natureza (state-of-nature maps), são os que exibem os dados sem interpretação, também podendo ser descritos como mapas temáticos/básicos (geológico, topográfico, dados de precipitação, etc.); 
Nível 2 - Mapas de Suscetibilidade ou de Tipologia ou Inventário de eventos perigosos, são aqueles que sugerem os principais e mais prováveis tipos e mecanismos destes eventos que podem ocorrer na área mapeada (inundações, movimentos de massa, solos colapsíveis, etc.);

Nível 3 - Mapas de Perigo (hazard maps), que devem apresentar as probabilidades dos tipos de eventos perigosos identificados no mapa de suscetibilidade (nível 2).

Nível 4 - Mapas de risco (risk maps), são aqueles que combinam o perigo de um evento perigoso com as perdas potenciais (danos potenciais em um determinado período de tempo); e

Nível 5 - Mapas de gerenciamento, onde devem ser exibidas as medidas de mitigação mais apropriadas aos tipos e níveis de risco identificados, dirigir a implantação de sistemas de monitoramento e emergência, e locais para execução de investigações complementares.

Tabela 4: Tipos de mapas geotécnicos (Bittar et al., 1992 apud Augusto Filho, 2001)

\begin{tabular}{|c|c|}
\hline MAPA GEOTÉCNICO & OBJETIVOS/CARACTERİSTICAS \\
\hline DIRIGIDA & $\begin{array}{l}\text { a partir da identificação de problemas de natureza geológico-geotécnica } \\
\text { decorrentes do uso do solo, expõem as limitações e potencialidades dos } \\
\text { terrenos, estabelecem alternativas de solução destes problemas e apontam as } \\
\text { diretrizes para o adensamento e a expansão da ocupação ante uma ou mais } \\
\text { formas de uso do solo. }\end{array}$ \\
\hline CONVENCIONAL & $\begin{array}{l}\text { apresentam a distribuição geográfica das características dos terrenos, } \\
\text { a partir de atributos do meio físico e de determinados parâmetros do } \\
\text { meio físico e as diferentes formas de uso do solo. }\end{array}$ \\
\hline SUSCETIBILIDADE & $\begin{array}{l}\text { indicam a potencialidade de ocorrência de processos naturais e induzidos em } \\
\text { áreas de interesse ao uso do solo, expressando a } \\
\text { suscetibilidade segundo classes de probabilidade de ocorrência }\end{array}$ \\
\hline RISCO & $\begin{array}{l}\text { prepondera a avaliação de dano potencial à ocupação, expresso segundo } \\
\text { diferentes graus de risco, resultantes da conjugação da probabilidade de } \\
\text { ocorrência de manifestações geológicas naturais } \\
\text { induzidas e das consequências sociais e econômicas decorrentes. }\end{array}$ \\
\hline
\end{tabular}

Este trabalho utilizará a estruturação proposta por Einstein (op. cit.), para gerar mapas até o nível 2.

\subsection{Eventos Perigosos de Natureza Geológica-Hidrológica em São Carlos.}

Bartolomeu (2012) em seu trabalho, ressaltou a probabilidade de que alguns vazamentos de postos possam ter ocorridos devido ao comportamento colapsível do solo em algumas regiões do município. 
De acordo com Giardini e Lorandi (2004), o rápido processo de urbanização e o crescimento desordenado das cidades alteram drasticamente a paisagem, caracterizada por diferentes processos do meio físico, em geral relacionados a alguma degradação ambiental. Assim feições erosivas, derivadas da má gestão do uso do solo e do precário planejamento urbano, causam impactos ambientais, pela produção de sedimentos que vão assorear as drenagens, provocando a ocorrência de enchentes e inundações em períodos de chuva intensa. A população de São Carlos-SP vem crescendo consideravelmente, como consequência, é possível observar a implantação de novos loteamentos, normalmente de forma caótica, onde sérios problemas de erosão urbana podem ser observados como por exemplo, nos bairros Cidade Aracy, Antenor Garcia entre outros.

O IPT (2015) em um mapeamento com o foco em áreas de risco a deslizamentos e inundações no município de São Carlos- SP, identificou uma área de alto risco para movimentos de encosta, quatro áreas de alto risco e quatro áreas de risco médio para inundação. O local onde o risco a movimentos de encosta é alto, localiza-se no bairro Cidade de Aracy, trata-se de um talude rochoso, onde não há moradias, porém existe propostas de empreendimentos imobiliários para ocupar o talude.

Observando os jornais televisivos e escritos da região de São Carlos, é notável que o evento perigoso que mais gera transtornos para a cidade são as enchentes/inundações. Em reportagem publicada pela EPTV em 23/11/2015 é mostrado o grande poder de destruição que este evento causa à cidade (Figura 5).

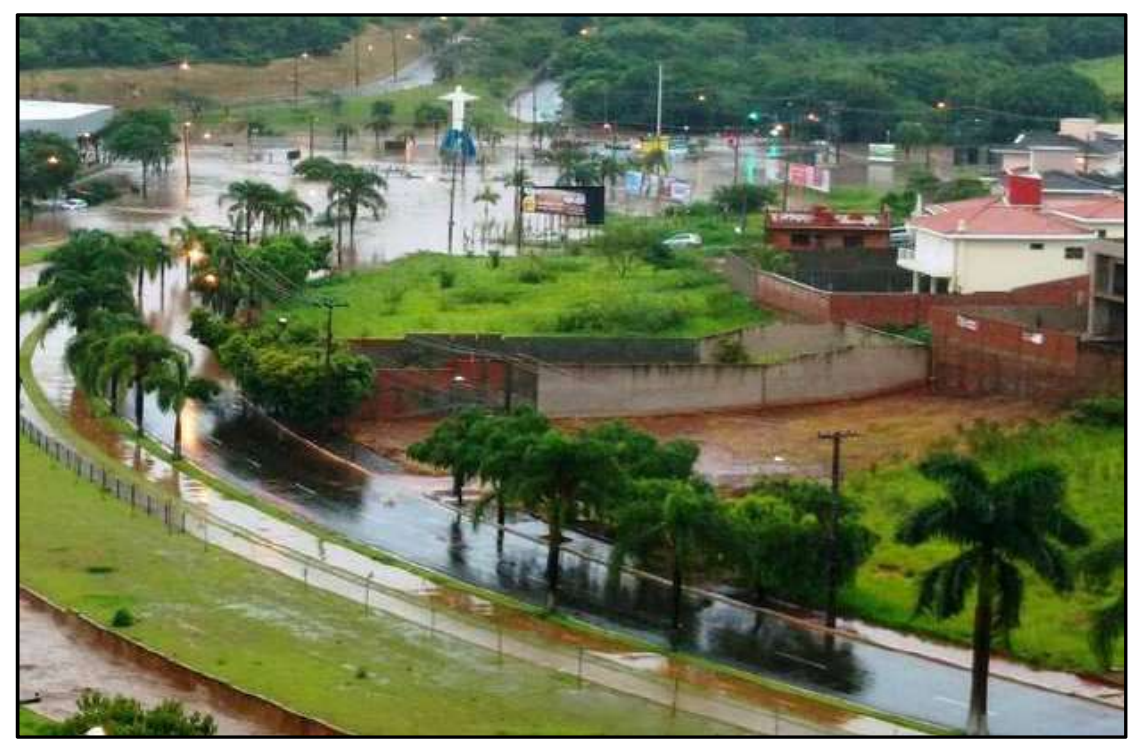

Figura 5: Inundação em São Carlos no dia 23/11/2015. (EPTV. 2015). 
Os próximos tópicos abordarão os eventos que mais causam transtornos à cidade de São Carlos, ou seja, erosão pluvial, solos colapsíveis, movimentos de encosta e enchentes/inundações.

\subsubsection{Erosão pluvial}

Segundo Vilar e Prandi (1993), erosão é um conjunto de ações pelas quais os materiais da crosta terrestre são desagregados, dissolvidos ou desgastados e sofrem transporte de um local ao outro na terra por agentes, como as geleiras, rios, mares, ventos ou chuvas. Neste trabalho, o foco principal será na erosão pluvial, visto que este tipo de processo erosivo é bastante frequente na cidade de São Carlos, gerando danos sociais e econômicos.

Em relação a este processo erosivo, pode-se destacar dois eventos iniciais fundamentais. Primeiramente, o impacto das gotas de chuva na superfície do solo, ocasionando a desagregação e liberação de suas partículas, e o escoamento superficial das águas, possibilitando o transporte das partículas liberadas. Quanto à forma na qual ocorre o escoamento superficial ao longo da vertente, podem-se desenvolver dois tipos de erosão: erosão laminar, que ocorre devido ao escoamento difuso das águas da chuva, gerando a remoção progressiva e relativamente uniforme dos horizontes mais superficiais do solo; e erosão linear, que acontece em consequência da concentração das linhas de fluxo das águas de escoamento superficial, gerando pequenas incisões na superfície do terreno, em forma de sulcos, que com o aprofundamento podem evoluir para ravinas. Caso a erosão evolua por controle não somente das águas superficiais, mas também dos fluxos d'agua subsuperficiais, em que se compreende o lençol freático, configura-se o processo conhecido por boçoroca. (Salomão e Iwasa, 1995)

O surgimento dos processos erosivos são conduzidos por diversos fatores, influenciados pelas condições naturais dos terrenos, evidenciando-se: a chuva, a cobertura vegetal, a topografia (formas de encosta e declividades) e os tipos de solo.

Com relação a chuva, a água gera a erosão do solo por meio do impacto das gotas sobre a superfície, caindo com velocidade e energia variáveis, e através do escoamento da água. Sua ação erosiva está diretamente relacionada a distribuição pluviométrica no tempo e espaço, e de sua intensidade. A cobertura vegetal é a defesa natural de um terreno contra a erosão, pois, protege o solo contra o impacto direto das gotas de chuva, dispersa e diminui a 
energia da água no escoamento, aumenta a infiltração pela produção de poros no solo, devido as raízes e aumenta a capacidade de retenção de água. A topografia influencia a intensidade do processo erosivo em decorrência principalmente, da declividade, comprimento da rampa e a forma da encosta, como consequência, estas características influenciam a velocidade do escoamento. Já as propriedades físicas do solo, entre elas, textura, estrutura, permeabilidade, e densidade, e as características químicas, biológicas e mineralógicas, interfere de várias formas no processo erosivo, ao atribuir maior ou menor resistência a ação das águas (Salomão e Iwasa, op. cit.).

A Tabela 5 sintetiza as principais feições que ocorrem em decorrência do escoamento superficial (Rotta e Zuquette, 2015).

Tabela 5: Feições resultantes do escoamento superficial.

\begin{tabular}{|c|c|c|}
\hline EROSÃO & FEIÇÕES & CARACTERÍSTICAS \\
\hline LAMINAR & Intersulcos & $\begin{array}{l}\text { Processo erosivo que acontece nas áreas entre sulcos/canais ao longo de uma } \\
\text { vertente ou talude escavado, sendo que o destacamento de partículas, se dá } \\
\text { principalmente devido ao impacto da gota de chuva. O transporte dos sedimentos } \\
\text { se dá por ação da queda das gotas de chuva em conjunto com o fluxo do } \\
\text { escoamento superficial. }\end{array}$ \\
\hline \multirow{3}{*}{ LINEAR } & Sulcos & $\begin{array}{l}\text { São pequenos canais bem definidos, em consequência do escoamento concentrado } \\
\text { em vertentes. Em relação à suas dimensões, considera-se que sua profundidade e } \\
\text { largura não ultrapassam } 50 \text { centímetros, no entanto podem se estender por } \\
\text { comprimentos da ordem de dezenas de metros. }\end{array}$ \\
\hline & Ravinas & $\begin{array}{l}\text { É resultado da evolução dos sulcos, sendo consideradas feições cuja recuperação } \\
\text { se torna mais complicada por uso de equipamentos mecânicos simples. Considera- } \\
\text { se que estas possuem largura superior a } 1 \text { metro e profundidades superiores a } 50 \\
\text { centímetros, mas menores que um metro. }\end{array}$ \\
\hline & Boçorocas & $\begin{array}{l}\text { É o estágio evolutivo de maior complexidade das erosões lineares. De uma maneira } \\
\text { geral, estas podem ser descritas como canais de paredes íngremes, com a } \\
\text { possibilidade de fluxo de água permanentemente, caso aconteça a interceptação do } \\
\text { lençol freático, ou efêmero, durante eventos chuvosos, e com cabeceiras bem } \\
\text { definidas. }\end{array}$ \\
\hline
\end{tabular}

\subsubsection{Solos colapsíveis}

Segundo Pinto (2006), solos colapsíveis são solos não saturados que possuem uma considerada e acelerada compressão quando submetidos a um acréscimo de umidade sem variar a tensão total a que são submetidos.

De acordo com Lollo e Rodrigues (2008), quando certos tipos de solos, sofrem um acréscimo de água em seus vazios, ou são umedecidos depois de sofrerem sobrecargas, estes podem vir sofrer uma diminuição de volume, demonstrada por uma variação do índice de 
vazios, sem que fundamentalmente tenha havido aumento de cargas aplicadas. Estes tipos de solo têm recebido o nome de solos colapsíveis.

Segundo Ferreira e Vilar (2015), nos solos de baixa densidade, o acréscimo de umidade implica em uma decréscimo da resistência nos contatos inter partículas, normalmente por diminuição da sucção, uma recolocação estrutural e uma nova condição de equilíbrio sob a carga influente. A esta condição do solo de demonstrar uma redução de volume quando umedecido, tem-se dado o nome de solo colapsível. As principais características dos solos colapsíveis são apresentadas na Tabela 6 .

Tabela 6: Principais características dos solos colapsíveis (Ferreira e Vilar, 2015)

\begin{tabular}{c}
\hline Características dos Solos Colapsíveis \\
\hline Solos não saturados. \\
\hline $\begin{array}{c}\text { Solos com estrutura porosa ou instável, com } \\
\text { partículas interligadas por argila, óxido de } \\
\text { ferro, alumínio ou carbonatos. }\end{array}$ \\
\hline $\begin{array}{c}\text { Solos de origem recente e de fácil drenagem } \\
\text { de regiões tropicais úmidas com lixiviação } \\
\text { dos horizontes superficiais. }\end{array}$ \\
$\begin{array}{c}\text { Solos em regiões onde a evapotranspiração } \\
\text { excede a precipitação, regiões de alternância } \\
\text { de estações secas e chuvas intensas e concentradas. }\end{array}$ \\
\hline
\end{tabular}

De acordo com Pinto (op. cit.,) o colapso do solo ocorre em consequência da destruição dos meniscos capilares, responsáveis pela tensão de sucção, ou a um amolecimento do cimento natural que sustenta as partículas e os agregados de partículas unidas. Fisicamente, o fenômeno do colapso está firmemente ligado a perda de resistência dos solos não saturados.

Segundo Lollo e Rodrigues, (op. cit.), o fenômeno da colapsividade pode ocorrer por ação conjunta ou simples de dois mecanismos: acréscimo do teor de umidade nos vazios do solo e/ou tensões que excedem o valor limite. Os solos da região centro-sul brasileiro (interior de São Paulo e Paraná) são solos porosos residuais, solos sedimentares ou colúvios com características de solos colapsíveis.

Para Lollo e Oliveira (2008) o colapso de solos representa hoje um dos maiores problemas geotécnicos da maioria da região sudeste do Brasil e, em particular, uma parcela expressiva do interior do estado de São Paulo. 
Dudley (1970), aponta duas características principais que configura um solo como colapsível: uma estrutura porosa (composta por um elevado índice de vazios) e uma umidade menor que a necessária para sua inteira saturação.

Segundo Cintra (1998) os solos colapsíveis tem os seguintes indicadores:

- Baixos valores de SPT ( $\leq 4$ golpes);

- Baixos valores de CPT(qc $\leq 1,0 \mathrm{Mpa})$;

- Granulometria aberta (ausência de fração silte);

- Baixo grau de saturação $(\mathrm{Sr} \leq 60 \%)$;

- Grande porosidade $(\mathrm{n} \geq 40 \%)$

As condições existentes para a identificação de solos colapsíveis seguem essencialmente, algumas medidas como, critérios "regionais" formulados para certas ocorrências de solos ou regiões, onde leva-se em conta conceitos empíricos e de alguns testes rápidos, critérios estes, fundamentados nos limites de consistência ou nas condições de compacidade do solo. Na Tabela 7, são exibidas alguma dessas condições (Ferreira e Vilar, op. cit.).

Tabela 7: Critérios de identificação de solos colapsíveis. Ferreira e Vilar, (2015).

\begin{tabular}{|c|c|c|}
\hline REFERÊNCIA & EXPRESSÃO & LIMITES \\
\hline $\begin{array}{l}\text { DENISOV (1951) citado por } \\
\text { REGINATTO (1970) }\end{array}$ & $K=\frac{e_{1}}{e_{0}}$ & $\begin{array}{l}\cdot 0,5<\mathrm{K}<0,75 \text {, altamente colapsivel } \\
\cdot \mathrm{K}=1 \text {, não colapsivel } \\
\cdot 1,5<\mathrm{K}<2 \text {, nåo colapsível }\end{array}$ \\
\hline FEDA (1966) & $K l=\frac{\left(\frac{w_{0}}{S_{0}}\right)-w_{p}}{w_{l}-w_{p}}$ & $\begin{array}{l}\text { Se So }>80 \% \text { e Kl }>0,85 \text {, o solo é } \\
\text { colapsivel }\end{array}$ \\
\hline $\begin{array}{l}\text { PRIKLONSKIJ (1952) citado por } \\
\text { FEDA (1966) }\end{array}$ & $K d=\frac{w_{l}-w_{0}}{w_{l}-w_{p}}$ & $\begin{array}{l}\text { - } \mathrm{Kd}<0 \text {, altamente colapsivel, } \\
\cdot \mathrm{Kd}>0,5 \text {, colapsivel e } \\
\cdot \mathrm{Kd}>1 \text {, expansivo }\end{array}$ \\
\hline GIBBS \& BARA (1962) & $R=\frac{w_{\text {sat }}}{w_{l}}$ & $\mathrm{R}>1$, colapsivel \\
\hline KASSIF e HENKIN (1967) & $K=\gamma_{d} \cdot w$ & $\mathrm{~K}<15$, colapsivel \\
\hline \multirow{3}{*}{ JENNINGS e KNIGHT (1975) } & Cascalho fino & \begin{tabular}{|l|}
$\mathrm{Sr}<6 \%$, colapsivel \\
$\mathrm{Sr}>10 \%$, não colapsivel \\
\end{tabular} \\
\hline & Areia fina & $\begin{array}{l}\mathrm{Sr}<50 \% \text {, colapsivel } \\
\mathrm{Sr}>60 \% \text {, nåo colapsivel }\end{array}$ \\
\hline & Silte argiloso & $\begin{array}{l}\mathrm{Sr}<90 \% \text {, colapsivel } \\
\mathrm{Sr}>95 \% \text {, não colapsível }\end{array}$ \\
\hline $\begin{array}{l}\text { Código de obras da URSS (1977) } \\
\text { citado por RESNIK (1989) }\end{array}$ & $\begin{array}{c}C I=\frac{e_{0}-e_{1}}{1+e_{0}} \\
S r<80 \%\end{array}$ & $\begin{array}{l}\text { Ocorre colapso para: } \\
\cdot 1 \% \leq \mathrm{wp} \leq 10 \%, \mathrm{CI}<0,1 \\
\cdot 10 \% \leq \mathrm{wp} \leq 14 \%, \mathrm{Cl}<0,17 \\
\cdot 14 \% \leq \mathrm{wp} \leq 22 \%, \mathrm{CI}<0,24\end{array}$ \\
\hline
\end{tabular}




\subsubsection{Movimentos de encosta}

Para Cruden (1991) apud Cruden e Varnes (1996) movimentos de encosta podem ser descritos como: movimento de massa de rocha, detritos ou solo por uma encosta.

Segundo Varnes (1978) e Augusto Filho (1992), são identificados quatro subgrupos básicos de movimentos de encosta: rastejos (creep); escorregamentos (slide); quedas (falls) e corridas (flows). A Tabela 8, exemplifica estes movimentos e suas características.

Tabela 8: Principais tipos de movimentos de massa associados a encosta (Augusto Filho, 1992).

\begin{tabular}{|c|c|}
\hline PROCESSOS & DINÂMICA/GEOMETRIA/MATERIAL \\
\hline Rastejos (creep) & $\begin{array}{l}\text { vários planos de deslocamento (internos); } \\
\text { velocidades muito baixas (cm/ano) a baixas e decrescentes com a } \\
\text { profundidade; } \\
\text { movimentos constantes, sazonais ou intermitentes em solo, } \\
\text { depósitos, rocha alterada/fraturada; } \\
\text { geometria indefinida. }\end{array}$ \\
\hline Escorregamentos (slides) & $\begin{array}{l}\text { poucos planos de deslocamento (externos); } \\
\text { velocidades médias (m/h) a altas (m/s); } \\
\text { pequenos a grandes volumes de material; } \\
\text { geometria e materiais variáveis: } \\
\text { Planares - solos pouco espessos, solos e rochas com } 1 \text { plano de } \\
\text { fraqueza; } \\
\text { Circulares - solos espessos homogêneos e rochas muito } \\
\text { fraturadas; } \\
\text { Em cunha - solos e rochas com dois planos de fraqueza. }\end{array}$ \\
\hline $\begin{array}{l}\text { Quedas } \\
\text { (falls) }\end{array}$ & $\begin{array}{l}\text { sem planos de deslocamento; } \\
\text { movimentos tipo queda livre ou em plano inclinado; } \\
\text { velocidades muito altas (vários } \mathrm{m} / \mathrm{s} \text { ); } \\
\text { material rochoso; } \\
\text { pequenos a médios volumes; } \\
\text { geometria variável: lascas, placas, blocos, etc; } \\
\text { Rolamento de matacão; } \\
\text { Tombamento. }\end{array}$ \\
\hline $\begin{array}{c}\text { Corridas } \\
\text { (flows) }\end{array}$ & $\begin{array}{l}\text { muitas superfícies de deslocamento; } \\
\text { movimento semelhante ao de um líquido viscoso; } \\
\text { desenvolvimento ao longo das drenagens; } \\
\text { velocidades médias a altas; } \\
\text { mobilização de solo, rocha, detritos e água; } \\
\text { grandes volumes de material; } \\
\text { extenso raio de alcance, mesmo em áreas planas. }\end{array}$ \\
\hline
\end{tabular}

Para rastejo, quedas e corridas serão utilizadas as definições de Bobrowsky e Highland (2008). 


\section{$\underline{\text { Rastejos }}$}

Rastejo é caracterizado por ser um movimento de massa bem lento, muitas vezes imperceptível, em taludes de solo e rocha. O movimento é consequência de uma tensão de cisalhamento suficiente para causar uma deformação permanente, porém insatisfatória para produzir o rompimento do talude. Existem três tipos de rastejo: (1) sazonal, onde o movimento é em uma certa profundidade do solo, sendo afetado pelas mudanças de umidade e temperatura; (2) contínua, onde a tensão de cisalhamento contínua excede a resistência do material e (3) progressiva, onde a encosta alcança o ponto de falha, como outros tipos de movimento. Rastejo é reconhecido em campo, por troncos de árvores curvadas, cercas desalinhadas e postes inclinados. A Figura 6a demonstra um movimento de rastejo.

\section{Quedas}

Quedas são movimentos de massa de materiais geológicos, como rochas e pedregulhos, que se destacam de encostas íngremes ou penhascos (Figura 6b). O rompimento ocorre ao longo de descontinuidades como fraturas, juntas e planos de dobra, e o movimento se dá em queda livre, saltando e rolando encosta abaixo. Esses movimentos são fortemente influenciadas pela gravidade, intemperismo mecânico, e a presença de água intersticial.

\section{$\underline{\text { Corridas }}$}

Esse tipo de movimento pode ser descrito como um movimento de massa muito rápido, sendo uma combinação de solo, rocha, material orgânico, ar e água, mobilizados como uma pasta fluida, que escoa encosta abaixo (Figura 6c). São normalmente causadas por intenso fluxo de água na superfície, devido a fortes precipitações, que destrói e mobiliza terra solta e pedaços de rocha pelas encostas. Corridas tem um grande poder de alcance e destruição, podendo se estender por quilômetros, até perder energia e se depositar nas áreas mais planas.

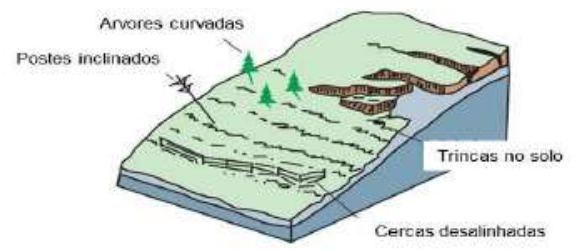

A

Figura 6: Ilustração mostrando o movimento de A-rastejo; B- queda; C-corrida. Bobrowsky e Highland (2008).

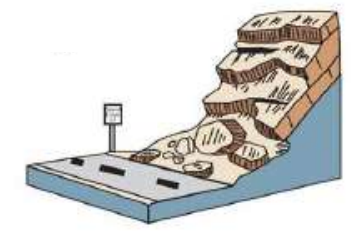

B

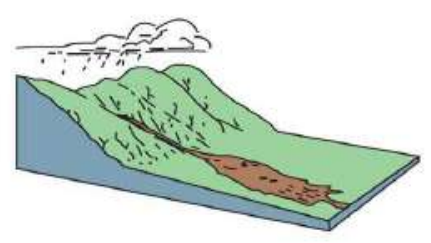

C 


\section{Escorregamentos}

De acordo com Varnes (1978), este tipo de movimento consiste no cisalhamento e rompimento ao longo de uma ou várias superfícies que são visíveis, ou pelo menos possam ser inferidas. O movimento pode ser progressivo, ou seja, o plano de cisalhamento não ocorre instantaneamente, mas sim se propaga até causar a ruptura.

Os dois principais tipos de escorregamentos são o rotacional, e o translacional.

- Rotacional - Nos escorregamentos rotacionais (Figura 7a), o material geológico movimentado não é muito deformado e, em geral, ocorre em perfis mais homogêneos. A superfície de ruptura deste movimento é curva e com concavidade apontada para a superfície do talude

- Planares - Os escorregamentos planares (Figura 7b), se individualizam por exibirem uma superfície de ruptura com forma mais ou menos planar, acompanhando de maneira geral as descontinuidades existentes nos materiais geológicos.

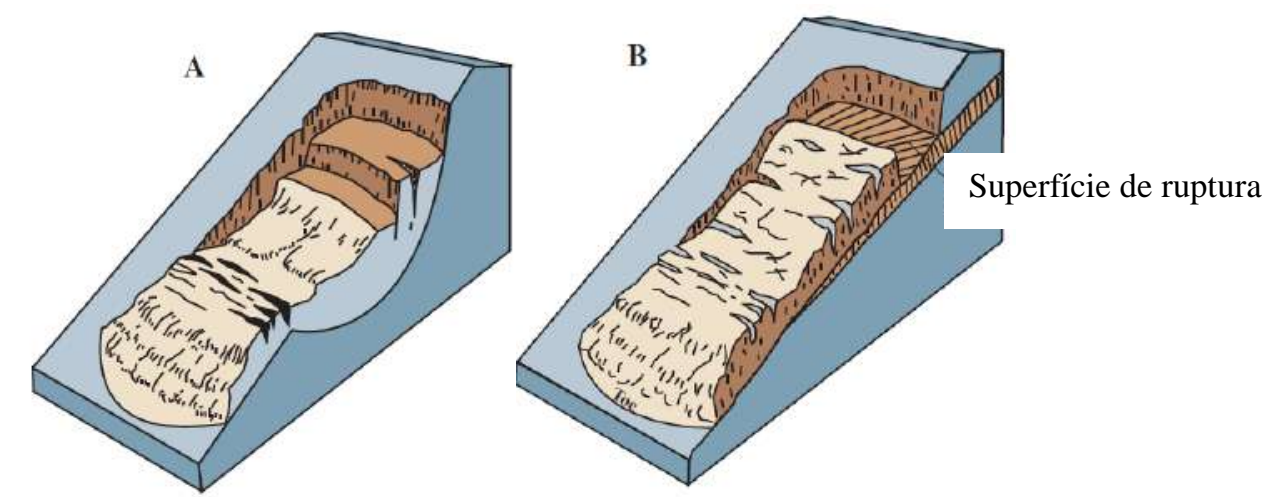

Figura 7: Processo de escorregamento planar. Bobrowsky e Highland (2008).

\subsubsection{Enchentes/inundações}

Segundo Tucci (2005), o escoamento pluvial pode gerar inundações e consequências negativas nas áreas urbanas, por meio de dois processos, que acontecem sozinhos ou em conjunto, sendo as inundações em áreas ribeirinhas e devido a urbanização. Em áreas ribeirinhas, ocorre devido ao fenômeno natural, em que o rio ocupa a sua planície de inundação, acarretando impactos adversos quando há uma ocupação inadequada do espaço urbano. Em cidades de relevo acidentado, as áreas mais propícias para a população ocupar, são as partes planas e baixas, consequentemente, as mais atingidas durante as cheias dos rios. 
Já nas áreas urbanas, ocorre nas drenagens em consequência da impermeabilização do solo, canalização do fluxo ou obstruções ao escoamento.

De acordo com Amaral e Ribeiro (2009), inundações e enchentes são eventos naturais que acontecem frequentemente nos cursos d'água, em decorrência quase sempre de chuvas fortes e rápidas ou de longa duração. Além dos conceitos de inundação e enchente, há também os conceitos de alagamento e enxurrada, muito utilizados em áreas urbanas. Assim, definemse:

Inundação: caracterizado pelo transbordamento das águas de um curso, alcançando a planície de inundação;

Enchentes ou cheias: originadas pela elevação do nível d'água no canal de drenagem em consequência do aumento de vazão, atingindo a cota máxima do leito menor, porém sem extravasar;

Alagamento: acúmulo rápido de águas em certos locais por impermeabilização, por consequência da deficiência de drenagem da superfície;

Enxurrada: escoamento superficial concentrado com grande energia de transporte, estando ou não associado a drenagens.

De acordo com Augusto Filho (2016), os processos de escoamento superficial relacionados as linhas de drenagens naturais são normalmente chamados de cheia, inundação e enchente. Para distinguir estes processos, observa-se a seção inundada do canal de drenagem. Os termos cheia e enchente são considerados sinônimos, e relacionam-se a elevação do nível d'água das drenagens acima dos valores médios, porém sem extravasar além do leito menor. O termo inundação, é utilizado quando o volume de água atinge o leito maior (planície de inundação), a até mesmo os terraços mais elevados (Figura 8).

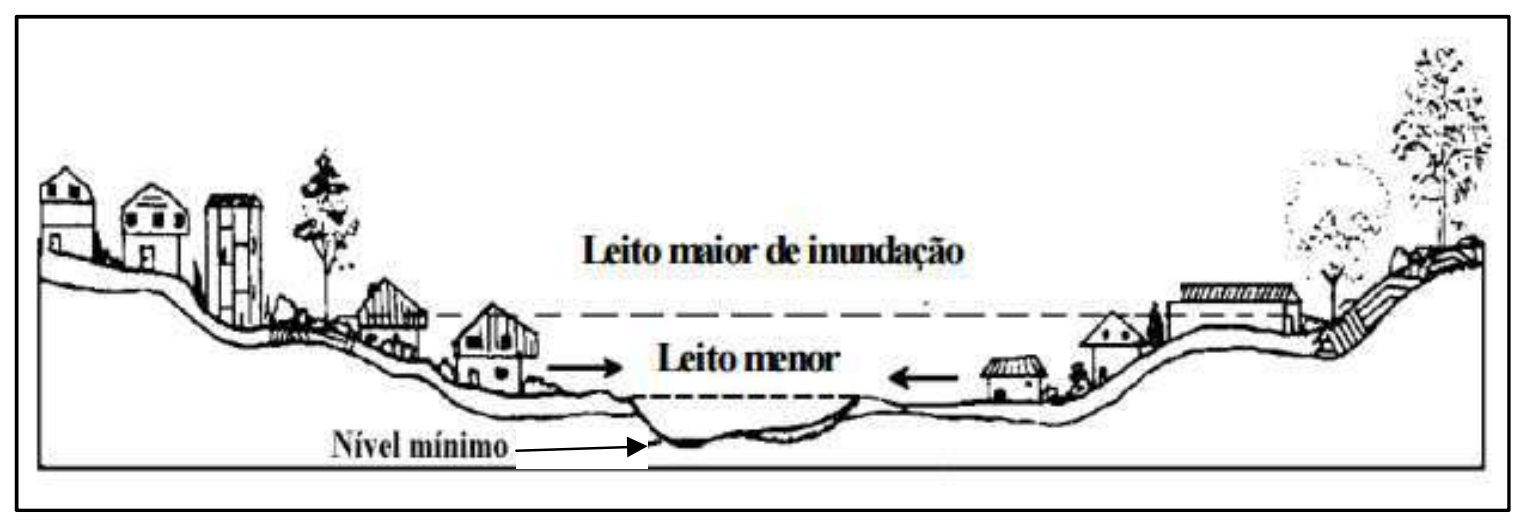

Figura 8: Características do leito do rio. Tucci (2005). 
De acordo com Infanti Jr e Fornasari Filho (1998), o processo de inundação mais frequente na área urbana de São Carlos (SP), é devido a urbanização, que ocorre devido ao extravasamento das águas de um curso d'água para as áreas adjacentes, quando a vazão escoada é maior que a capacidade de descarga da região.

Segundo Amaral e Ribeiro (op. cit.), a frequência de inundações e enchentes são dependentes da combinação de condicionantes naturais e antrópicos. Entre os naturais pode-se destacar:

- Formas do relevo;

- Características da rede de drenagem da bacia hidrográfica;

- Características do solo e o teor de humidade;

- Presença ou ausência da cobertura vegetal;

- Intensidade, quantidade, distribuição e frequência das chuvas.

É importante observar que os quatro primeiros condicionantes estão relacionados a bacia hidrográfica, enquanto que o último a precipitação.

Dentre os condicionantes antrópicos pode-se destacar:

- Disposição inadequada de lixo e entulho próximo ao curso d'água;

- Impermeabilização dos solos;

- Assoreamento;

- Retificações e canalizações.

\subsection{Sistemas de Informação Geográfica (SIG)}

Segundo Tomlin (1990), Sistema de Informação Geográfica (SIG) é um elemento que permite, analisar, apresentar e interpretar os dados relacionados a superfície da Terra. Um SIG é um conjunto de software e hardware, projetado especificamente para a aquisição, gerenciamento e uso de dados cartográficos.

Star e Estes (1990), define um SIG como sendo um sistema de informação desenhado para trabalhar com dados referenciados mediante coordenadas espaciais ou geográficas. Em outras palavras, um SIG é tanto um sistema de base de dados com capacidades específicas 
para dados georreferenciados, quanto um conjunto de operações para trabalhar com estes dados.

Um SIG permite a realização das seguintes operações (Olaya, 2011):

- Leitura, edição, armazenamento e, em termos gerais, gestão de dados espaciais;

- Análise dos dados. Isto inclui, desde consultas simples a elaboração de modelos complexos, e pode ser realizada tanto em relação a componente espacial dos dados como em relação a componente temática;

- Geração de resultados como, mapas e gráficos, entre outros.

Segundo Olaya (op. cit.), um SIG é formado por uma série de subsistemas, sendo que cada um é encarregado de uma série de funções particulares. O autor cita três subsistemas fundamentais:

- Subsistema de dados. Se encarrega das operações de entrada e saída de dados, e a gestão destes, dentro do SIG. Permite aos outros subsistemas ter acesso aos dados e realizar suas funções baseados neles;

- Subsistema de visualização e criação cartográfica. Cria representações a partir dos dados (mapas, legendas), permitindo a interação entre eles. Incorpora também as funcionalidades de edição;

- Subsistema de análise. Contém métodos e processos para as análises dos dados geográficos.

Segundo Augusto Filho (2015), apesar da existência de vários programas de SIG disponíveis no mercado, é possível estabelecer relações comuns entre eles, dentre as quais pode-se apontar: utilização dos meios digitais; necessidade de uma base de dados integrada, georreferenciada e com controle do erro; inclusão de funções de análise desses dados e efetivação de operações algébricas simples, complexas e lógicas. As diferenças conceituais dos vários programas de SIG hoje em dia disponíveis, podem ser correlacionadas com a maneira como eles lidam com os dois tipos fundamentais de arquiteturas de dados espaciais digitais: vetorial e matricial (Figura 9). Na arquitetura vetorial, cada elemento é determinado por uma lista ordenada de coordenadas $\mathrm{x}$, y (dados discretos), e na matricial (raster), os elementos, são compilados na forma de uma matriz, e a cada elemento da malha (grid), é conferido um valor (dados contínuos). 
REPRESENTAÇÃOVETORIAL

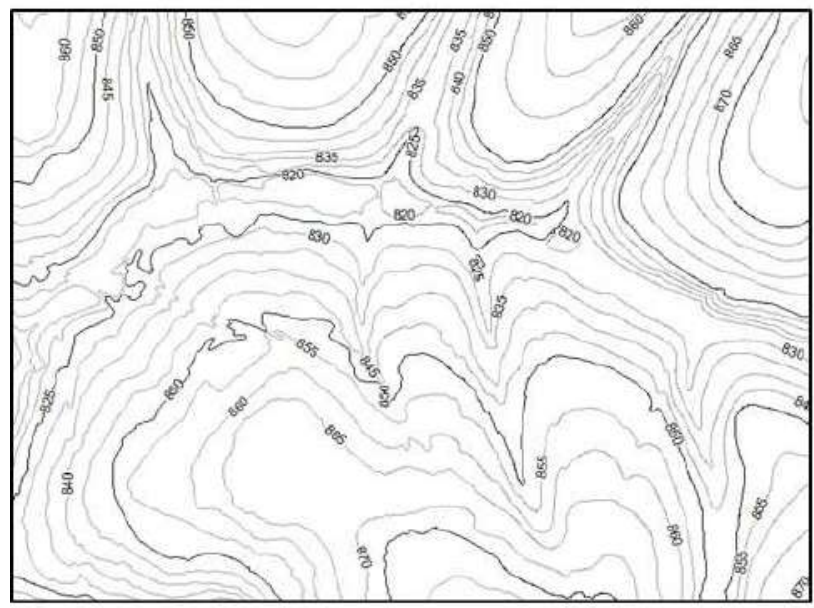

REPRESENTAÇÃO RASTER

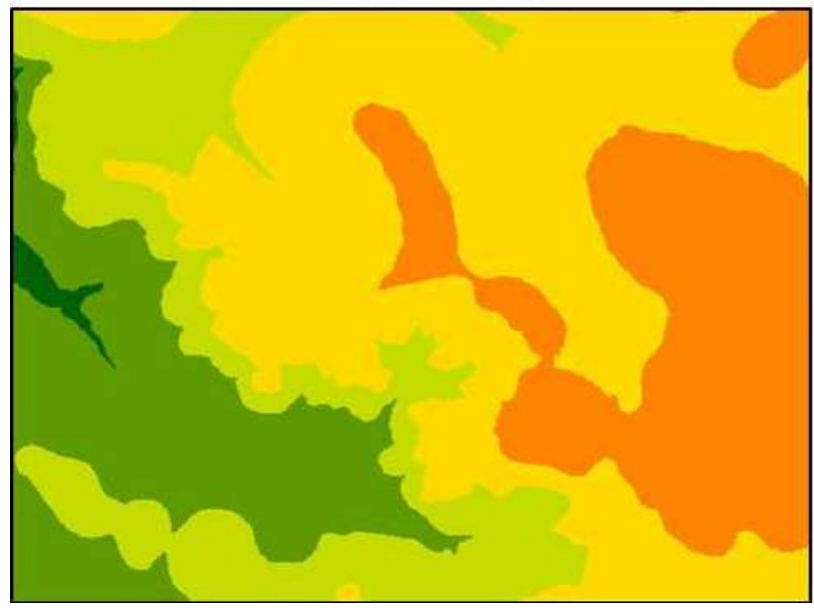

LEGENDA

ELEVAÇÕES (m)

- $658-700$

$701-750$

$\square 751-800$

$\square 801-850$

- $851-900$

$901-950$

Figura 9: Tipos fundamentais de estrutura de dados digitais em SIG.

De acordo com Augusto Filho (op. cit.), outra característica fundamental dos programas de SIG para dados vetoriais, são suas estruturas dual, onde é possível relacionar uma tabela aos dados vetoriais. Como pode ser observado na Figura 10, existe uma tabela para os pontos cotados e outra para as curvas de nível, que apresenta as características para cada ponto e linha biunivocamente.

A utilização de maneira correta do SIG requer o conhecimento de alguns princípios fundamentais da engenharia cartográfica, com ênfase para os sistemas de projeção cartográfica e as escalas de trabalho. O domínio das principais características dos sistemas de projeção cartográfica e a adoção de escalas de trabalho ajustadas às condições de contorno do projeto de SIG são imprescindíveis para a estruturação correta da base de dados digitais e o controle do erro. 


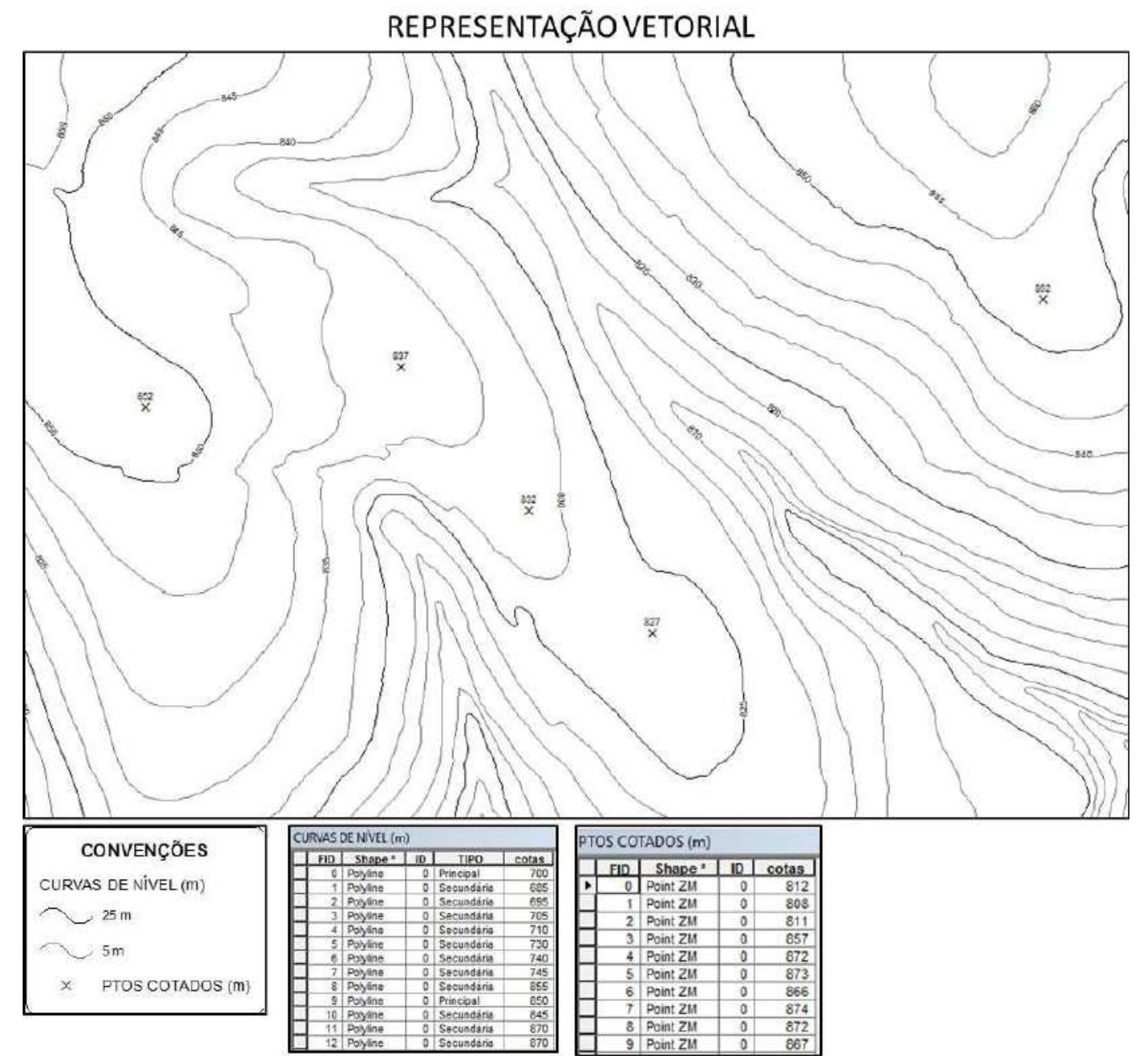

Figura 10: Estrutura dual e atribuída ao objeto para dados vetoriais em SIG.

Esta ferramenta de gerenciamento de dados, suporta bancos de informações espacializadas e georreferênciadas, tornando-se uma ferramenta formidável para mapeamentos temáticos, rápida tomada de decisão, assim como a realização de análises multicritérios. O sistema permite também, uma visualização e impressão em diversas escalas. Atualmente nos trabalhos onde é necessário gerar mapas, o uso de um Sistema de Informação Geográfica, é cada vez mais comum. Augusto Filho (2001) utilizou o ambiente SIG para gerar uma carta de risco de escorregamentos em Caraguatatuba (SP). Graciosa (2010), confeccionou um modelo de seguro para riscos hidrológicos usando softwares hidrológicos e hidráulicos integrados com um SIG para a bacia do Gregório em São Carlos (SP). Lollo e Sena (2013), utilizaram o Sistema de Informações Geográficas para estabelecer a suscetibilidade a erosões.

Como pode ser visto, o SIG é uma ferramenta muito poderosa, onde pode-se trabalhar dados dos mais simples aos mais complexos, para gerar mapas dos mais simples, como um 
topográfico, ou de drenagens, até mapas mais complexos como os de perigo e risco. Nesta pesquisa será utilizado o software ArcGis ${ }^{\circledR} 10.3$, devido à sua alta eficiência e grande aplicabilidade.

\subsection{Chuvas Como Agente Deflagrador}

Um modo de se avaliar a relação das chuvas com a deflagração de eventos perigosos geológicos e hidrológicos é procurar definir valores limite de um certo índice pluviométrico acima dos quais esses eventos têm uma maior probabilidade de ocorrer. Uma aplicação baseada em métodos empíricos foi realizada por Chleborad et al. (2006), na análise de movimentos de encostas em Seattle, nos Estados Unidos. A partir da avaliação de dados históricos de 91 movimentos de encosta entre 1933 e 1997 determinou-se o cumulative rainfall threshold (CT), índice que relaciona as chuvas acumuladas dos últimos 3 e 15 dias.

No Brasil, Guidicini e Iwasa (1977) analisaram movimentos de encostas em nove diferentes regiões do pais, que ocorreram em decorrência de grandes volumes de chuvas, com durações entre algumas horas até dois ou três dias. O estudo indicou a relevância da relação do ciclo de precipitação e o evento associado, e definiu o coeficiente do ciclo (CC) e o coeficiente do evento (CE). O CC é determinado como a precipitação acumulada até a data do evento, dividida pela precipitação anual média, enquanto o CE é obtido a partir da relação entre a precipitação registrada durante o evento e a precipitação anual média. A soma dos dois coeficientes resulta no coeficiente final $(\mathrm{CF})$. Os autores observaram que os movimentos de encostas eram mais prováveis de deflagrarem, quando a precipitação acumulada tinha um acréscimo de porcentagem (8-17\%) em relação a precipitação média anual.

No trabalho de Tatizana et al. (1987) foram usados dados de chuvas diárias para análise da correlação entre as precipitações e os movimentos de massa na Serra do Mar, em Cubatão. No processo de desestabilização do talude, foram consideradas como eficazes, chuvas acumuladas de 4 dias. No estudo estabeleceu-se uma função entre a intensidade horária e a acumulada antecedente, classificada como envoltória de escorregamentos, a partir do qual foi gerado o CPC (coeficiente de precipitação crítica) que avalia a suscetibilidade a deslizamentos com o desenvolvimento da precipitação, sendo atribuído pela relação entre a energia da chuva horária e a energia crítica para a ocorrência destes eventos. 
Cerri et al. (1990) com a objetivo de implantar um plano preventivo na defesa civil para diminuir os problemas gerados por movimentos de massa em municípios na baixada santista e litoral norte do estado de São Pulo, empregaram uma adaptação do coeficiente de ciclo, chamada coeficiente de ciclo móvel (CCM).

A mudança da proposta foi dividir o acumulado de chuva do período considerado pelo acumulado de chuva normal para o mesmo período, segundo a Equação 1:

$$
C C M=\frac{\text { acumulado de chuva de junho até o dia } i}{\text { acumulado normal de chuva no mesmo período }}
$$

A partir dos valores acumulados de precipitações normais mensais, obteve-se o acumulado normal de chuva. A chuva normal é obtida pela divisão da precipitação acumulada média mensal pelo número de dias do mês correspondente, como se chovesse a mesma quantidade todos os dias ao longo do mês. $\mathrm{O}$ acumulado de precipitações até o dia i, significa a soma das chuvas equitativamente distribuídas desde $1^{\circ}$ de junho (começo no ano hidrológico) até o dia i (dia em que se quer fazer a análise), levando em conta que o ano hidrológico vai até maio do ano subsequente. Por levar em conta os dados normais de precipitação, O CCM incorpora em seu cálculo as características da região analisada. Assim sendo, a deflagração de escorregamentos é mais provável para valores superiores a 1, ou seja, quando a chuva acumulada é maior do que a média aguardada para aquele período. Vale ressaltar que o cálculo do CCM pode gerar valores pouco representativos para o começo do mês de junho, de maneira que chuvas intensas logo no começo do ano pluviométrico geram valores muito altos de CCM. Por outro lado, enquanto não forem anotadas chuvas (numerador da equação 1 igual a 0), o CCM será 0 . Com o passar do ano pluviométrico os valores de CCM tendem a se normalizarem.

\subsection{Mapeamento de Suscetibilidade}

Existem vários métodos de mapeamento com o objetivo de gerar mapas de suscetibilidade. Para a geração de cartas de suscetibilidade quanto a processos erosivos, Lollo e Sena (2013), sugerem levar em conta informações relacionadas ao substrato rochoso, materiais inconsolidados, declividade, landforms e ocupação do solo, buscando hierarquizar as áreas em função da sua potencialidade em desenvolver processos erosivos. Os pesos para cada atributo na avaliação de suscetibilidade à erosão na região, é dado levando em conta 
fatores multiplicadores, que variam em consequência da importância considerada que o atributo desempenha no processo erosivo na área, caso por caso.

Para a erosão Laminar foi desenvolvida nos Estados Unidos da América - EUA em 1978 a Equação Universal de Perdas de Solo, amplamente utilizada (Salomão e Iwasa, 1995). É expressa pela Equação 2:

$$
A=R . K . L . S . C . P
$$

$\mathrm{A}=$ representa a estimativa de perda média anual de solo em determinada área, em condições especificas de uso e ocupação do solo.

$$
\begin{aligned}
& \mathrm{R}=\text { Erosividade da chuva. } \\
& \mathrm{K}=\text { Erodibilidade do solo. } \\
& \mathrm{L}=\text { Comprimento de rampa. } \\
& \mathrm{S}=\text { Declividade de rampa. } \\
& \mathrm{C}=\text { Uso e manejo do solo. } \\
& \mathrm{P}=\text { Práticas conservacionistas. }
\end{aligned}
$$

Segundo Salomão e Iwasa (op.cit.), a determinação dos valores de perda de solo provocados pela erosão laminar, deve ser expresso em t/ha, e realizado a partir do cálculo dos índices de cada componente da Equação 2. Este cálculo é tanto mais preciso quanto menor a parcela da área estudada, levando em consideração as variações espaciais usualmente observadas nos terrenos, em relação aos fatores analisados.

Pejon e Ferreira (2015), propõe uma sequência de procedimentos a serem adotados para a elaboração de cartas de suscetibilidade a erosão, que podem ser observadas na Figura 11. 


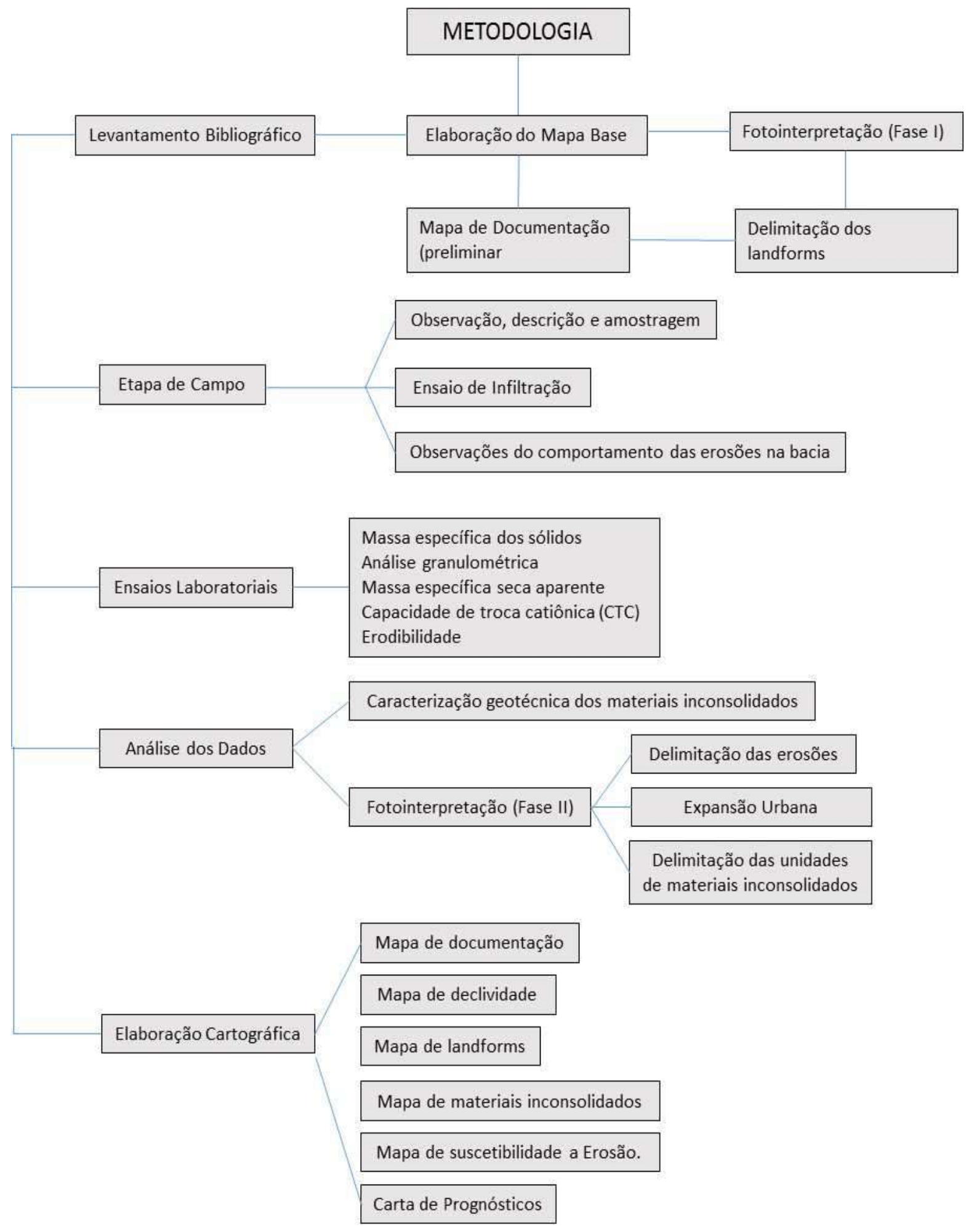

Figura 11: Sequência de obtenção de informações para a elaboração de carta de suscetibilidade à erosão (Pejon e Ferreira, 2015).

Quanto a movimentos de encosta, Augusto Filho (1995), propõe o seguinte método (Figura 12). 


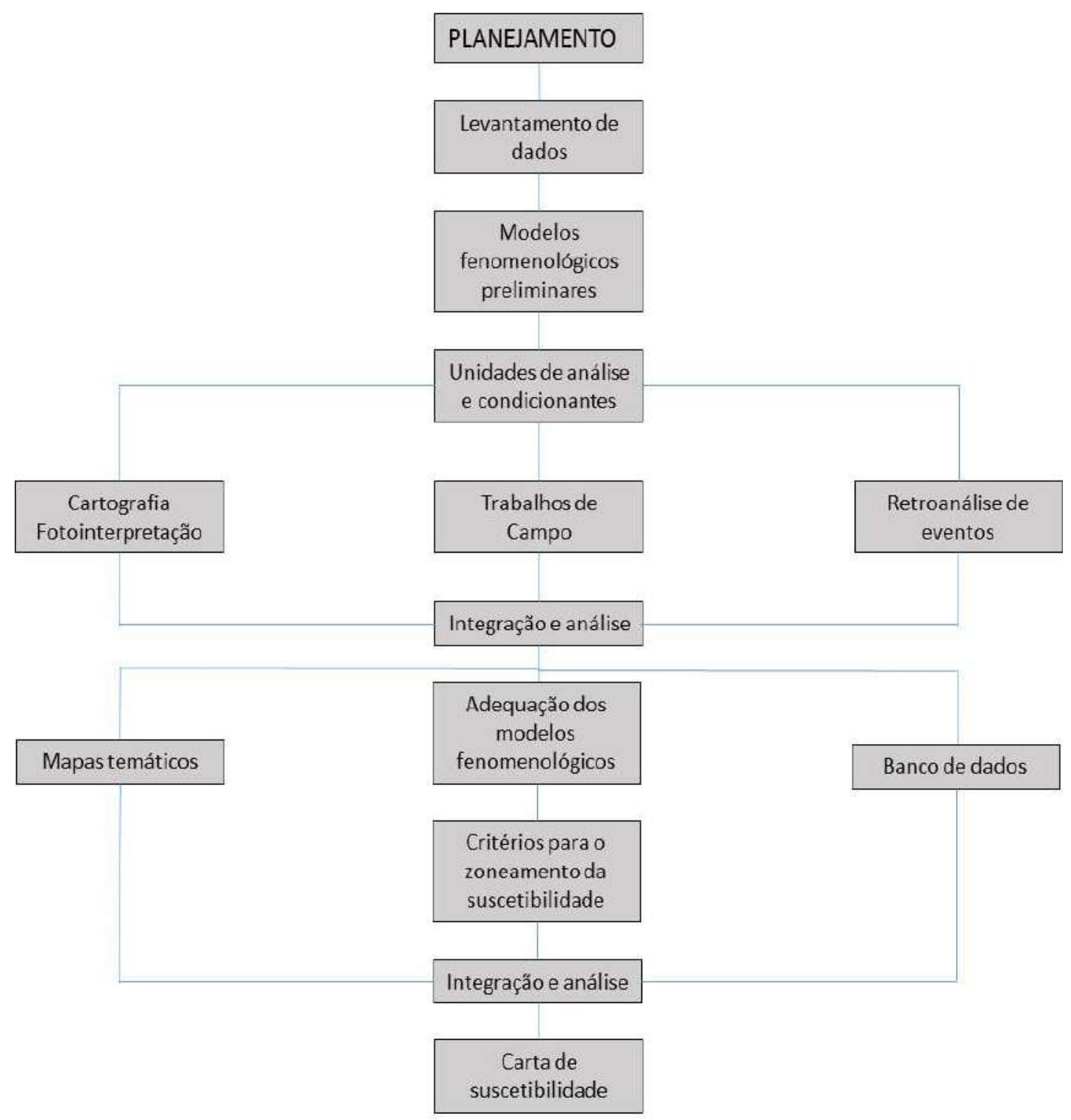

Figura 12: Método para elaboração de cartas de suscetibilidade para movimentos de encosta (Augusto Filho, 1995).

O IUGS Working Group - Committee on Risk Assessment (1997), propõe oito métodos principais para a análise de suscetibilidade e perigo quanto a movimentos de encosta:

- Através de dados históricos, ou seja, eventos e acidentes decorrentes de movimentos ocorridos na área de estudo;

- Através de métodos empíricos, fundamentados em relações de acordo com sistemas de ranqueamento do grau de instabilidade das encostas;

- Através do uso de evidência geomorfológica, combinada com dados históricos ou abalizada no julgamento;

- Através da correlação da frequência dos eventos versus o agente deflagrador; 
- Através da avaliação direta fundamentada na avaliação de especialistas, a qual pode ser realizada tendo como base um modelo conceitual, como por exemplo o uso da árvore de falha;

- Através da modelagem de variáveis primárias, como correlações entre pressões neutras versus deflagração do escorregamento, combinado com diversos níveis de informação sobre a geometria da ruptura e a resistência ao cisalhamento;

- Através da utilização de métodos probabilísticos formais, considerando as incertezas associadas a geometria da encosta, parâmetros de resistência, mecanismo de deslizamento, e pressões atuantes;

- Através da combinação dos métodos descritos acima.

Augusto Filho (2001) utilizou o método de sobreposição de mapas (método overlay) que consiste no cruzamento de mapas temáticos, para auxiliar na geração de mapas de risco de escorregamentos em Caraguatatuba.

Uma das análises quanto a suscetibilidade, em relação à inundação, é obter uma correlação entre chuvas e inundações, e cruzar estes resultados com os mapas básicos, um dos métodos utilizados é o Racional. Segundo Augusto Filho (2016), tal método foi introduzido em 1889 e é amplamente utilizado nos Estados Unidos e em outros países.

Os princípios fundamentais desta metodologia, de acordo com Tucci (1993), são:

- Considera-se a duração da precipitação intensa, igual ao tempo de concentração. Assim, aceita-se que a bacia é consideravelmente pequena, já que a duração é inversamente proporcional a intensidade. Em bacias de pequeno porte, eventos críticos ocorrem em consequência de fortes chuvas em um curto espaço de tempo;

- Considera-se um coeficiente único de perdas, chamado de $\mathrm{C}$, determinado, levando em conta as características da bacia;

- O volume de cheia e a distribuição temporal das vazões não são analisados.

No método racional, as vazões máximas em relação a intensidade pluviométrica são obtidas pela Equação 3, que emprega um fator de correção para a distribuição de chuvas na bacia:

$$
Q=166,67 \times C \times i \times A \times D
$$


onde,

- $\mathrm{Q}=$ vazão máxima $(1 / \mathrm{s})$;

- $\mathrm{C}=$ coeficiente de escoamento superficial;

- $\quad \mathrm{I}=$ intensidade da chuva crítica $(\mathrm{mm} / \mathrm{min})$;

- $\mathrm{A}=$ área da bacia de contribuição (ha);

- $\mathrm{D}=$ coeficiente de distribuição da chuva.

Para $\mathrm{A}<50$ ha, $\mathrm{D}=1$; para $\mathrm{A}>50$ ha, $\mathrm{D}=1-0,009 \mathrm{~L} / 2$, onde: $\mathrm{L}$ comprimento do talvegue $(\mathrm{km})$.

Algumas condições básicas são seguidas quando se aplica o Método Racional (PMSP, 1999, apud Augusto Filho, 2016):

- O pico do ESD (Escoamento Superficial Direto) do local de estudo é função do tempo de concentração, bem como da magnitude da precipitação;

- As características de permeabilidade superficiais da bacia ficam constantes durante a precipitação;

- O pico de ESD acontece quando a área total de drenagem, a montante da área de pesquisa passa a contribuir no escoamento.

Alguns autores como Benini et al. (2004), já utilizaram o método racional aliado ao SIG para prever vazões de bacias. No caso, o autor utilizou o método para a cidade de São Carlos.

Segundo o DNIT (2005), o método racional tem sido empregado preferencialmente em bacias com pequenas áreas de drenagem, mas não há indícios de que não possa ser adaptado para bacias maiores, prática bastante comum em outros países.

Para a identificação e análise de suscetibilidade quanto a colapsividade de materiais geológicos Ferreira e Fucale (1999), utilizaram como base ensaios de campo (ensaios SPT em sondagens de simples reconhecimento) e laboratório (ensaios endométrico). Oliveira e Lollo (2001) fizeram um zoneamento de materiais colapsíveis em Ilha Solterira (SP) utilizando como base a identificação de materiais inconsolidados a partir de landforms e registro de processos históricos de colapsos. 
Augusto Filho e Ridente Junior (1999) apud Lollo (2012), utilizaram para a área urbana de São José do Rio Preto, a krigagem de dados de sondagens de simples reconhecimento e ensaios SPT de 64 locais prospectados, com o propósito inicial de representar espessura de solos da área, e de resistência a penetração de acordo com o número de golpes do SPT. Apesar deste objetivo inicial, a pesquisa possibilitou interpretações quanto a colapsividade, visto que alguns resultados mostraram valores muito baixos de compacidade para os materiais inconsolidados.

Mendes e Lorandi (2002) prepararam uma carta para fundações rasas como subsídio para o planejamento urbano em São José do Rio Preto. Os autores se fundamentaram em dados de sondagens de simples reconhecimento (profundidade do nível d'água e índice $\mathrm{N}_{\mathrm{spt}}$ ) analisados em função da declividade dos terrenos e informações de ensaios de penetração de cone (CPT). O mapa final mostrou grandes porções da área urbana suscetíveis a colapsividade, com mais de $70 \%$ da área classificada nas classes moderada e severa.

Para gerar os mapas de suscetibilidade, esta pesquisa se fundamentará em itens propostos pelo IUGS Working Group - Committee on Risk Assessment (op.cit.), que visa a obtenção de dados históricos dos eventos e acidentes ocorridos na área de estudo e a correlação da frequência dos eventos versus as áreas dos condicionantes. 


\section{MATERIAIS E MÉTODOS}

\subsection{Materiais}

Os materiais utilizados na presente pesquisa foram: documentos cartográficos; imagens de satélite (Google Earth Pro ${ }^{\circledR}$ ); equipamentos para campo; programas de computador; jornais e ocorrências registradas na defesa civil (Tabela 9).

Tabela 9: Principais materiais utilizados na pesquisa.

\begin{tabular}{l|l}
\hline $\begin{array}{l}\text { Documentos cartográficos 1:10.000, } \\
\text { digitalizados por - Bartolomeu } \\
(2012) .\end{array}$ & $\begin{array}{l}\text { SF-23- Y-A-I-1-NO-B; SF-23- Y-A-I-1-NE-A; SF-23 } \\
\text { YA- I-1-NO-D; SF-23-V-C-IV-3-SO-F; SF-23- V-C- } \\
\text { IV-3- SE-E; SF-23- Y-A-I-1-NE-C }\end{array}$ \\
\hline $\begin{array}{l}\text { Mapa de compartimentos geológico- } \\
\text { geotécnicos }\end{array}$ & $\begin{array}{l}\text { Mapa produzido em pesquisa de mestrado por } \\
\text { Bartolomeu (2012) }\end{array}$ \\
\hline $\begin{array}{l}170 \text { imagens de satélite (Google } \\
\text { Earth Pro }{ }^{\circledR} \text { ) com datas variando de } \\
2014 \text { a 2016. }\end{array}$ & $\begin{array}{l}\text { Imagens na escala 1:3.000 contendo toda a área de } \\
\text { estudo, com datas variando de 2014 a 2016. }\end{array}$ \\
\hline Principais equipamentos utilizados. & GPS Garmin 76S e máquina fotográfica. \\
\hline Jornais. & $\begin{array}{l}\text { Jornais (A Folha; A Tribuna; A Notícia local; EPTV, } \\
\text { Primeira Página; Região em Destake; Revelando São } \\
\text { Carlos; São Carlos Agora; São Carlos Dia e Noite; São } \\
\text { Carlos em Rede) com datas entre 1965 a 2016. }\end{array}$ \\
\hline Ocorrências da Defesa Civil. & $\begin{array}{l}\text { Ocorrências registradas na Defesa Civil entre os anos } \\
\text { de } 2005 \text { a 2012. }\end{array}$ \\
\hline Principais programas utilizados. & ArcGis 10.3 ${ }^{\circledR}$ e Pacote Office ${ }^{\circledR}$.
\end{tabular}

\subsection{Métodos}

O método combina abordagens qualitativas e quantitativas de mapeamento de eventos perigosos propostas pelo Working Group Committee on Risk Assessment (1997). Inicialmente, utilizou-se a análise histórica dos eventos hidrológicos e geológicos, e a freqüência destes eventos, em função da área dos condicionantes cartografados nos mapas temáticos. Os condicionantes foram analisados isoladamente e sobrepostos, na forma de classes de terreno. Einstein (1988) denomina os níveis de suscetibilidade obtidos desta forma como probabilidades iniciais (prior probabilities). A pesquisa se apoiou nos trabalhos de Einstein (op. cit.), Augusto Filho (2001), Bartolomeu (2012), entre outros trabalhos e atividades realizadas na região. 
Com base nestes pressupostos, a pesquisa foi desenvolvida seguindo as etapas e atividades descritas nos itens a seguir (Tabela 10).

Tabela 10: Etapas, atividades da pesquisa e produtos gerado.

\begin{tabular}{|c|c|c|}
\hline ETAPAS & ATIVIDADES PRINCIPAIS & PRODUTOS \\
\hline Planejamento & $\begin{array}{l}\text { Definição dos objetivos, da área de } \\
\text { estudo, dos processos a serem } \\
\text { investigados, da linha metodológica e } \\
\text { dos temas da revisão bibliográfica }\end{array}$ & Projeto de pesquisa \\
\hline Revisão Bibliográfica & $\begin{array}{c}\text { Pesquisa bibliográfica, busca de } \\
\text { produtos cartográficos, de bases digitais } \\
\text { e de ensaios geotécnicos }\end{array}$ & $\begin{array}{c}\text { Bases conceituais para o } \\
\text { desenvolvimento da pesquisa }\end{array}$ \\
\hline Inventário & $\begin{array}{l}\text { Confecção da base cartográfica digital; } \\
\text { Levantamento dos eventos perigosos } \\
\text { em São Carlos; Levantamentos de } \\
\text { campo; Caracterização pluviométrica; } \\
\text { Elaboração de mapas temáticos. }\end{array}$ & $\begin{array}{c}\text { Base cartográfica digital; Banco de } \\
\text { dados digital dos eventos perigosos } \\
\text { ocorridos entre 1965 a 2016; Dados } \\
\text { de campo; Dados de pluviometria; } \\
\text { Mapa de declividades; Mapa de } \\
\text { formas de encosta; Mapa de } \\
\text { compartimentos geológico- } \\
\text { geotécnicos; Mapa de uso e } \\
\text { ocupação; Mapa de documentação. }\end{array}$ \\
\hline Análise & $\begin{array}{l}\text { Correlação entre os índices } \\
\text { pluviométricos e enchentes/inundações, } \\
\text { alagamentos e movimentos de encosta; } \\
\text { Elaboração de mapas de concentração } \\
\text { dos eventos; Elaboração dos mapas de } \\
\text { suscetibilidade }\end{array}$ & $\begin{array}{c}\text { Mapas de concentração para } \\
\text { enchentes/inundações, alagamentos, } \\
\text { movimentos de encosta, erosão } \\
\text { pluvial e solos colapsíveis; Mapas } \\
\text { de suscetibilidade para } \\
\text { enchentes/inundações, movimentos } \\
\text { de encosta, erosão pluvial e colapso } \\
\text { de solos. } \\
\end{array}$ \\
\hline Síntese & $\begin{array}{l}\text { Apresentação e discussão dos } \\
\text { resultados; Redação da dissertação }\end{array}$ & Dissertação de mestrado \\
\hline
\end{tabular}

\subsubsection{Planejamento}

Foi realizada uma análise preliminar do problema em questão, considerando os eventos perigosos de natureza hidrológica e geológica mais comuns, e com potencial para causar transtornos (enchentes/inundações; processos erosivos; movimentos de encosta e solos colapsíveis) no município de São Carlos - SP. Nesta etapa, foi definida à área de estudos como sendo a mesma área estudada por Bartolomeu (2012), em consequência do autor em seu trabalho, ter gerado uma boa base de dados digitais, como a rede de drenagens, pontos cotados, curvas de nível e mapa geológico-geotécnico.

Foram organizados os tópicos inerentes ao trabalho proposto, para verificar a viabilidade da pesquisa, considerando o tema, estrutura do departamento e tempo disponível para a 
pesquisa. Posteriormente definiu-se o objetivo principal da pesquisa, seguido pelo método a ser utilizado e os temas principais a serem abordados na revisão bibliográfica, por fim, redigiu-se o projeto de pesquisa.

\subsubsection{Revisão bibliográfica}

Nesta fase, foi realizada uma revisão bibliográfica, que teve como objetivo buscar em trabalhos de doutorado, mestrado, monografias, artigos, entre outros, informações relevantes, e inerentes aos seguintes temas: Trabalhos na Área de Estudo Anteriores Correlatos ao Tema Investigado; Conceitos Básicos; Tipos de Mapas Geotécnicos; Eventos Perigosos de Natureza Geológica-Hidrológica em São Carlos; Erosão Pluvial; Solos Colapsíveis; Movimentos de Massa; Enchentes/Inundações; Sistemas de Informação Geográfica (SIG); Chuvas como agente deflagrador e Mapeamento de Suscetibilidade.

Também foram levantadas informações fundamentais da área de estudo, como dados de ensaios de laboratórios (índices físicos e granulometria), histórico de chuvas de postos pluviométricos, informações referentes ao estado atual do meio físico (geológico, geotécnico, geomorfológico) e informações relacionadas ao meio socioeconômico, comprovando a relevância do estudo.

\subsubsection{Inventário}

\subsubsection{Elaboração da base cartográfica digital.}

Com os dados levantados no inventário e a atualização e complementação da base cartográfica realizada por Bartolomeu (2012), foi elaborada uma base cartográfica digital (curvas de nível, drenagens, bacias, pontos cotados, principais vias de acesso, modelo digital do terreno e mosaico de imagens de satélite) na escala 1:10.000.

A partir das curvas de nível, foi gerado o modelo digital do terreno (MDT). Foi empregado o método de interpolação, que considera as curvas de nível (espaçadas em 5 m), os pontos cotados e o sentido da rede de drenagem. O comando utilizado foi, "Topo to raster" dentro de Raster Interpolation do módulo 3D Analyst tools do ArcToolBox. O espaçamento utilizado (grid) na interpolação foi de 5 metros. 
A próxima etapa foi aplicar um filtro no MDT gerado, para eliminar possíveis ruídos (picos e buracos) decorrentes da interpolação. Esta ferramenta encontra-se em Arctoolbox Spatial Analyst Tools - Neighborhood - Filter.

Posteriormente, para a validação do MDT, testou-o qualitativamente, com a ferramenta "Raster Surface - Contour" no 3D Analyst tools do Arctoolbox. A partir do MDT foram geradas curvas de nível, para desta forma, comparar estas curvas com as originais, como as originais sobrepôs as obtidas no processo, o MDT foi elaborado corretamente.

O mosaico foi feito, utilizando 170 imagens de satélite (Google Earth Pro ${ }^{\circledR}$ ), fornecidas pela empresa Digital Globe, na escala 1:3.000. Optou-se por capturar imagens na escala mencionada, devido a riqueza de detalhes necessária, visto que este mosaico foi imprescindível para a confecção do mapa de uso e ocupação, bem como o reconhecimento de cicatrizes de movimentos de encosta, e feições erosivas.

Foi criada uma malha $18 \times 11$ de 198 pontos no Excel $^{\circledR}$, com coordenadas respeitando a escala adotada e abrangendo a área de estudo. Estas coordenadas foram exportadas para o ArcGis $10.3^{\circledR}$, e logo em seguida salva em "klm" (extensão compatível com o Google Earth Pro $\left.^{\circledR}\right)$.

No Google Earth Pro ${ }^{\circledR}$, com a malha de pontos aberta, foram capturadas 170 imagens (datas variando de 2014 a 2016), com cada imagem contendo 4 pontos da malha. Em seguida estas imagens foram exportadas para o SIG novamente, e georreferenciadas uma a uma. Foi, utilizado a ferramenta Georeferencing, que consiste em ligar os pontos das imagens aos pontos da malha.

Após georreferenciar as 170 imagens, foi utilizada uma ferramenta que por meio das interseções destas imagens uma com as outras, as unem, transformando-as em somente uma figura para toda a área. Esta ferramenta encontra-se em ArcToolBox - Data Management Tools - Raster - Raster Dataset - Mosaic to New Raster.

\subsubsection{Levantamento de eventos perigosos}

Foi realizado um levantamento dos eventos perigosos que geram transtornos para São Carlos (enchentes/inundações; processos erosivos; solos colapsíveis e movimentos de encosta) nas ocorrências diárias, registradas entre os anos de 2005 a 2012 na defesa civil da 
cidade. Além disso, realizou-se uma busca criteriosa no mosaico de imagens de satélite com o objetivo de registrar feições erosivas e cicatrizes de movimentos de encosta.

Também foi feita uma investigação nos principais jornais do município. A pesquisa em jornais de papel, foi feita na biblioteca da câmara municipal, que possui um acervo dos jornais da cidade.

Primeiramente foi escolhido o jornal, "A Folha", por se tratar do jornal com registros mais antigos e de circulação diária. Os jornais estão encadernados por mês e ano, sendo que o caderno mais antigo é de janeiro do ano de 1965. A pesquisa foi feita em todos os jornais de 1965 a 2015. Observou-se que em alguns cadernos, faltavam algumas datas, ou até mesmo alguns cadernos em determinados anos, portanto, optou-se por pesquisar também no jornal, "A Tribuna", entre os anos de 1970 a 2009, no entanto só foi registrado os eventos que não haviam sido encontrados no primeiro jornal.

Também foi feita uma busca nos sites dos seguintes jornais: A Notícia local; EPTV; Primeira Página; Região em Destake; Revelando São Carlos; São Carlos Agora; São Carlos Dia e Noite; São Carlos em Rede.

Para cada jornal, foi realizada uma investigação dos registros mais antigos nos sites (meados da década de 2000 até 2016). Todos os eventos registrados (papel e meio eletrônico) foram planilhados em Excel $^{\circledR}$, de acordo com as seguintes características: data; evento; local e jornal. Como é comum um evento ser noticiado em vários jornais, adotou-se como critério, registrar a noticia que fornecesse as informações mais completas.

\subsubsection{Levantamentos de campo}

Esta etapa ocorreu durante grande parte da pesquisa, do inventário até a fase final de análise dos resultados. Foram realizados levantamentos de campo, com o coordenador municipal da Defesa Civil, para verificar os pontos mais críticos em relação aos eventos perigosos investigados neste trabalho. Os pontos observados foram fotografados e registrados com o uso do GPS Garmin 76S.

Após a elaboração dos mapas temáticos, realizou-se mais trabalhos de campo, para a checagem das feições cartografadas nos mapas de declividades, formas de encosta, compartimentos geológico-geotécnicos e de uso e ocupação. Aproveitou-se esta etapa 
também, para conferir algumas localizações de eventos perigosos, que nos jornais, não tinham os endereços completos.

Por fim, foram feitas etapas de campo para a validação dos mapas de suscetibilidade obtidos, e checar se as feições estavam condizentes com os resultados alcançados.

\subsubsection{Caracterização da pluviometria}

Foi utilizada a caracterização pluviométrica realizada por Silva Júnior (2016), que a partir da seleção de postos pluviométricos e uma estruturação do banco de dados de pluviometria, analisou a variabilidade espacial das chuvas na região de estudo, calculando quatro índices pluviométricos, sendo eles, a média mensal, a precipitação máxima mensal, a precipitação máxima diária e a precipitação anual média, sendo que nesta pesquisa somente os dois últimos foram utilizados. Os índices foram calculados para cada posto pluviométrico, de acordo com o alcance de suas respectivas séries históricas.

Para gerar o mapa de distribuição espacial das médias anuais, efetuo-se uma interpolação dos resultados obtidos de cada posto pluviométrico. Os valores foram distribuídos em 5 intervalos, com base no método estatístico de quebras naturais (natural breaks), onde as classes são determinadas, ao encontrar pares de características adjacentes entre os quais, existe uma diferença relativamente grande no valor dos dados (ESRI 2017a). Os índices foram divididos em 5 categorias de intensidade (muito baixa; baixa; média; alta e muito alta).

\subsubsection{Elaboração dos mapas temáticos}

- Mapa de declividades

A partir do Modelo Digital do Terreno gerado, foi feito o mapa de declividades (raster). Foi utilizado a ferramenta dentro do software, que está disponível no comando "slope" dentro de "Raster Surface" do módulo 3D Analyst tools do ArcToolBox, e utilizou-se as medidas de declividade em porcentagem. Foram definidos 5 intervalos $(0$ a $5 \% ; 5$ a 10\%; 10 a 18\%; 18 a 33\% e > 33\%) utilizando o método estatístico de classificação Natural Breaks.

Para cada um destes intervalos foi definida a porcentagem que cada um ocupa na área. Utilizou-se a ferramenta Reclassify dentro de Reclass do módulo Spatial Analyst Tools do 
ArcToolBox. Esta opção reclassifica o raster e mostra quantos pixels cada classe ocupa, tornando simples a conversão para porcentagem e unidades de área.

- Mapa de formas de encosta

A partir do Modelo Digital do Terreno, foi gerado o mapa de forma de encosta (raster), este mapa mostra se as encostas são coletoras, dispersoras ou planas. Foi utilizado o método dentro do software, que está disponível no comando "curvature" dentro de "Raster Surface" do módulo 3D Analyst tools do ArcToolBox. Segundo o Help do próprio ArcGis $10.3^{\circledR}$, valores negativos do raster representam encostas coletoras, valores positivos, encostas dispersoras, enquanto valores igual a 0 representam encostas planas.

Para cada uma destas encostas foi definida a porcentagem que cada um ocupa na área. Utilizou-se a ferramenta Reclassify dentro de Reclass do módulo Spatial Analyst Tools do ArcToolBox.

- Mapa de compartimentos geológico-geotécnicos

Foi utilizado o mapa de compartimentos geológico-geotécnicos (vetorial) gerado por Bartolomeu (2012). Este mapa foi elaborado a partir de um mapeamento realizado pelo autor, onde foram identificados os compartimentos: Coluvionar; Aluvionar; Itaqueri; Serra Geral e Botucatu. Esta subdivisão em compartimentos foi definida de acordo com os limites litológicos mapeados e os materiais inconsolidados.

Para cada compartimento, foi calculada á área que o mesmo ocupa na região de estudo, utilizou-se a ferramenta dentro da tabela de atributos, calculate geometry, que fornece a área na unidade desejada.

- Mapa de uso e ocupação

A partir da análise do mosaico de imagens de satélite, foi realizado o mapa de uso e ocupação (vetorial). Foram definidas 6 classes (agricultura; área de expansão; área urbana; fragmento de mata, indústria e reflorestamento), em consequência destas serem as mais representativas na área de estudo. Com o uso da ferramenta Editor - Construction Tools Polygon, foram criados os polígonos para cada classe de uso. 
Para cada uma das classes foi calculada á área, utilizou-se a ferramenta dentro da tabela de atributos, calculate geometry.

- Mapa de documentação

O mapa com a localização dos eventos perigosos, foi realizado utilizando os dados coletados na etapa, "pesquisa dos eventos perigosos em São Carlos". Com base nos endereços colhidos nos jornais e defesa civil, demarcou-se os pontos utilizando o Google Earth Pro ${ }^{\circledR}$ e o Google Maps ${ }^{\circledR}$. Todos os pontos, após registrados, foram exportados para SIG. As feições erosivas e cicatrizes de movimentos de encosta, observadas no mosaico foram diretamente demarcadas no ArcGis $10.3^{\circledR}$.

Devido a dificuldade de ser feita alguma diferenciação tanto nas noticias de jornais quanto nos registros da defesa civil, os eventos hidrológicos enchente e inundação, foram agrupados em enchente/inundação, e os que não se enquadraram neste grupo, foi classificado como alagamento.

Vale ressaltar que o Google Eart Pro ${ }^{\circledR}$ utiliza o sistema de coordenadas geográficas "WGS 1984", portanto foi utilizada a seguinte ferramenta: ArcToolBox - Data Management Tools - Projections and Transformations - Feature - Project, para passar todos os pontos para o sistema de coordenadas UTM Córrego Alegre 23S, mesmo sistema utilizado em todos os mapas da pesquisa.

\subsubsection{Análise}

Em um primeiro momento utilizou-se o Excel $^{\circledR}$, para analisar a porcentagem de cada evento em relação ao total de eventos registrados. Verificou-se também a distribuição temporal, em relação aos anos, décadas e meses, e espacial em relação às bacias hidrográficas.

Em seguida, foi utilizado a ferramenta Extract Multi Values to Points dentro de Extraction - Spatial Analyst Tools - ArcToolBox para extrair as informações de declividade, formas de encosta, uso e ocupação e compartimentos geotécnicos relacionados a cada evento cadastrado.

Posteriormente, utilizando a ferramenta Select By Attributes, contabilizou-se o número de eventos que ocorrem em cada classe (eventos $/ \mathrm{Km}^{2}$ ) de cada condicionante (probabilidades 
iniciais). Dados de ensaios de laboratório de Aguiar (1989) e Bartolomeu (2012) também foram planilhados para a análise de certos critérios como porosidade e grau de saturação, para assim determinar se o solo possui ou não comportamento colapsível.

\subsubsection{Correlação entre índice pluviométrico e eventos de enchentes/inundações, alagamentos e movimentos de encosta}

Esta etapa foi realizada por Silva Júnior (2016), cujo projeto de iniciação científica, "Estudo da pluviometria para análise de eventos perigosos de natureza hidrológica e geológica em São Carlos - SP" foi vinculado a presente pesquisa. Foram utilizados os valores de chuvas diárias e o $\mathrm{CCM}$ diário (Equação 1), nas correlações com os eventos de enchentes/inundações, alagamentos e movimentos de encosta.

Os valores de CCM relacionados aos eventos e suas relativas precipitações acumuladas em $24 \mathrm{~h}$ foram inseridos em gráficos. Foram plotados gráficos de evolução do CCM nos anos de 2014 a 2016, enfatizando os eventos ocorridos, e gráficos relacionando o CCM com os acumulados em $24 \mathrm{~h}$ relativos aos eventos. Essas análises possibilitaram relacionar o CCM e a precipitação diária com a deflagração de eventos perigosos na região da pesquisa, além de permitir a definição inicial de valores limites de CCM para deflagrar esses eventos.

\subsubsection{Elaboração de mapas de concentração de eventos}

Estes mapas foram gerados utilizando a seguinte ferramenta: ArcToolBox - Spatial Analyst Tools - Density - Kernel Density. Segundo a ESRI (2017b), este método calcula a magnitude por unidade de área para cada ponto, usando uma função de Kernel para criar uma superfície que é suavizada do núcleo para a borda, ou seja, esta ferramenta faz uma busca, por cada ponto (evento) no raio determinado, para verificar a existência de um outro ponto na proximidade. Definiu-se o raio de pesquisa como sendo de $1 \mathrm{Km}^{2}$, devido a análise dos eventos por classes dos condicionantes terem sido feitas por $\mathrm{Km}^{2}$, esta função é importante pois considera a influência de pontos próximos, criando uma superfície contínua, desta forma representando as regiões com mais eventos. Foi gerado mapas de concentração para todos os eventos mapeados na pesquisa. 


\subsubsection{Elaboração dos mapas de suscetibilidade}

Foi utilizado o método da sobreposição de mapas (método overlay), onde foi feito o cruzamento de mapas temáticos para gerar as classes de terreno (Figura 13). Em seguida utilizou-se a concentração dos registros históricos dos eventos em cada classe de terreno (evento/Km ${ }^{2}$ ), como quantificador da suscetibilidade, desta forma, gerando os mapas de suscetibilidade. Apesar da base cartográfica estar na escala 1:10.000, os mapas são apresentados na escala 1:20.000, com o objetivo destes serem impressos em papéis no formato A1.

O mapa de classes de terreno foi elaborado pelo cruzamento dos mapas de declividade, formas de encosta, compartimentos geotécnicos e de uso e ocupação. Das 450 classes teóricas possíveis, resultantes da combinação de 5 classes de declividade $(0 \%$ a 5\%; $5 \%$ a $10 \% ; 10 \%$ a $18 \% ; 18 \%$ a $33 \%$ e $>33 \%$ ) com 3 tipos de formas de encostas (coletora; dispersora e plana) com 6 classes de uso e ocupação (agricultura; área de expansão; área urbana; fragmento de mata; indústria e reflorestamento) e com 5 classes de compartimentos geotécnicos (Coluviões; Aluviões; Itaqueri; Serra Geral e Botucatu), foram verificadas a ocorrência de 305 classes.

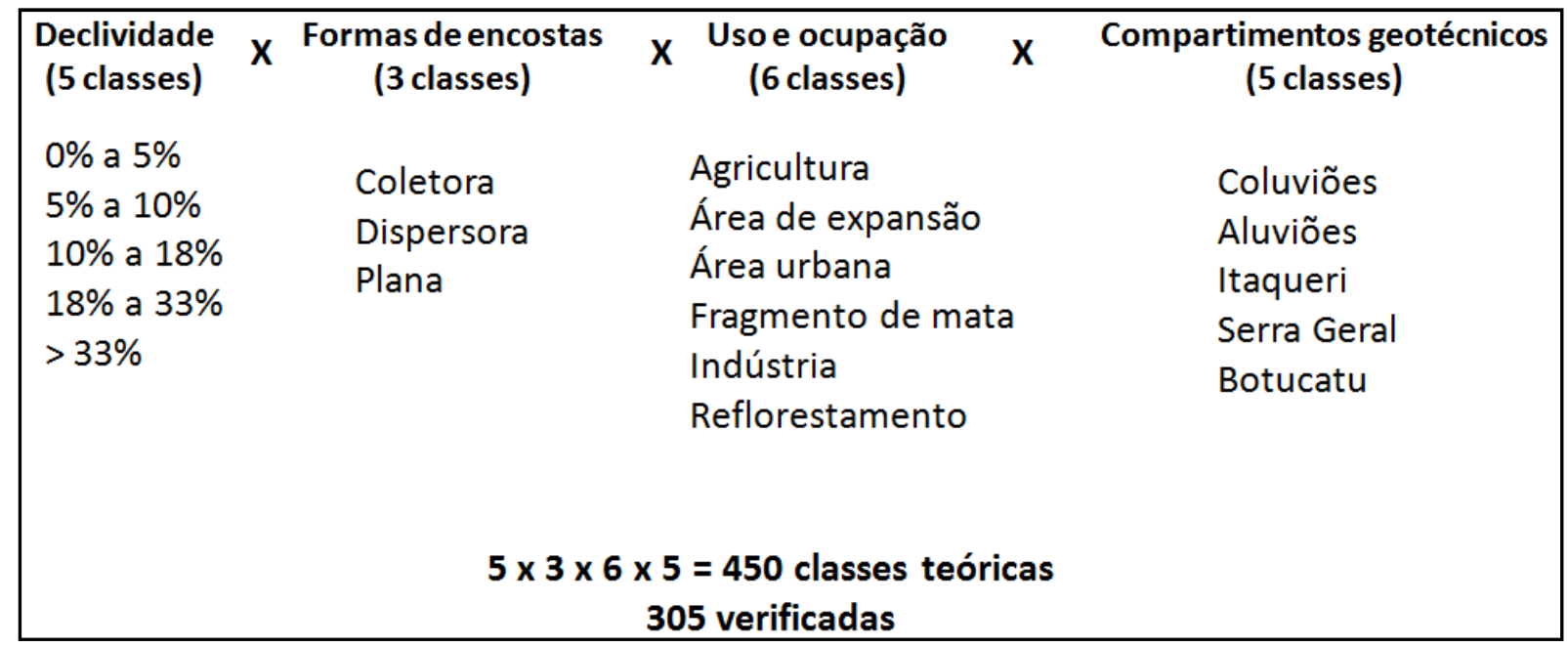

Figura 13: Classes de terreno possíveis resultantes do cruzamento dos mapas temáticos.

Para o cruzamento, primeiramente cada mapa temático foi reclassificado, foi utilizado o comando Reclassify - Reclass - Spatial Analyst Tools - do ArcToolBox e atribuiu-se um Gridcode (Cod) para cada classe de cada mapa temático (Tabela 11). Utilizando esta ferramenta todos os mapas passam a ser do tipo raster. 
Tabela 11: Valores atribuídos para cada classe de cada mapa temático.

\begin{tabular}{|c|c|c|c|c|c|c|c|}
\hline Uso e ocupação & Cod & $\begin{array}{c}\text { Compartimentos } \\
\text { Geotécnicos }\end{array}$ & Cod & Forma de Encosta & Cod & $\begin{array}{c}\text { Classes de } \\
\text { Declividade }\end{array}$ & Cod \\
\hline Agricultura & 1000 & Coluvionar & 100 & Coletora & 10 & $0 \%$ a $5 \%$ & 1 \\
\hline Área de Expansão & 2000 & Aluvionar & 200 & Plana & 20 & $5 \%$ a $10 \%$ & 2 \\
\hline Área Urbana & 3000 & Itaqueri & 300 & Dispersora & 30 & $10 \%$ a $18 \%$ & 3 \\
\hline Fragmento de Mata & 4000 & Serra Geral & 400 & & & $18 \%$ a $33 \%$ & 4 \\
\hline Indústria & 5000 & Botucatu & 500 & & & $>33 \%$ & 5 \\
\hline Reflorestamento & 6000 & & & & & & \\
\hline
\end{tabular}

Após, utilizou-se o comando Raster calculator - Map Algebra - Spatial Analyst Tools do ArcToolBox para somar estes mapas e conseqüentemente verificar as classes existentes na área (305 classes).

Após, utilizou-se a ferramenta Raster to Polygon dentro de From Raster em Conversion Tools do ArcToolBox, para transformar o produto obtido na etapa anterior (raster) em polígono (vetorial). Foram gerados 235.142 polígonos, posteriormente utilizou-se a ferramenta Dissolve dentro de Geoprocessing, para unir as classes de terrenos iguais, obtendo assim, 305 polígonos, cada um representando uma classe de terreno.

Em seguida, utilizou-se a ferramenta Join - Join data form another layer based on spatial location, que conta o numero de pontos (eventos) inseridos em cada classe de terreno. Após, para cada evento separadamente, dividiu-se o numero de eventos pertencentes a cada classe de terreno, pelas suas respectivas áreas, criando assim um índice de suscetibilidade para cada classe de terreno. Finalmente, utilizando estes índices, compartimentou-se os mapas em 5 intervalos de suscetibilidade (Muito alta; Alta; Média; Baixa; Muito baixa), utilizando o método "intervalos geométricos". Este método é recomendado quando mais de $50 \%$ dos registros são iguais a 0 , como no casso do presente trabalho, onde, para todos os eventos, em mais de 50\% das classes de terrenos não há a ocorrência de eventos perigosos. (ESRI, 2017a)

Depois com o objetivo de deixar o mapa mais continuo e mais refinado na versão impressa, utilizou-se a ferramenta Eliminate Polygon Part - Generalization - Data Management Tools - ArcToolBox, para eliminar os polígonos com menos de $10.000 \mathrm{~m}^{2}(0,5$ $\mathrm{cm}^{2}$ em escala de impressão), pois regiões com esta área são desprezíveis na escala adotada. Este comando incorpora os polígonos com a área especificada que estão inseridos dentro de outros polígonos maiores. 


\subsubsection{Síntese}

Nesta etapa, os resultados alcançados nas fases anteriores foram sistematizados, analisados e discutidos. Buscou-se analisar, se os objetivos propostos foram alcançados para posteriormente formular as conclusões, juntamente com sugestões de continuidade da pesquisa para futuros trabalhos. Como produto final, gerou-se a dissertação de mestrado. 


\section{RESULTADOS E DISCUSSÕES}

\subsection{Base Cartográfica Digital}

A base cartográfica digital é composta pelos seguintes arquivos vetoriais: curvas de nível (m); rede de drenagens; principais vias; pontos cotados (m) e identificação da área urbana. Estas informações estão apresentadas no Apêndice B, em conjunto com o mapa de documentação. Como complemento foi gerado um modelo digital de terreno, essencial para a confecção de alguns dos mapas temáticos, bem como um mosaico com imagens de satélite do Google Earth Pro ${ }^{\circledR}$. A área de estudo possui no total, $148,97 \mathrm{Km}^{2}$.

\subsubsection{Mosaico de imagens de satélite}

Primeiramente foi criada uma malha de pontos (Figura 14), que com o seu auxílio, foi feito um mosaico com 170 imagens de satélite obtidas a partir do Google Earth Pro ${ }^{\circledR}$ (Figura 15), as imagens foram capturadas em uma escala de detalhe de 1:3.000, georreferenciadas e agrupadas para formar uma só imagem. Este mosaico foi utilizado para a confecção do mapa de uso e ocupação.

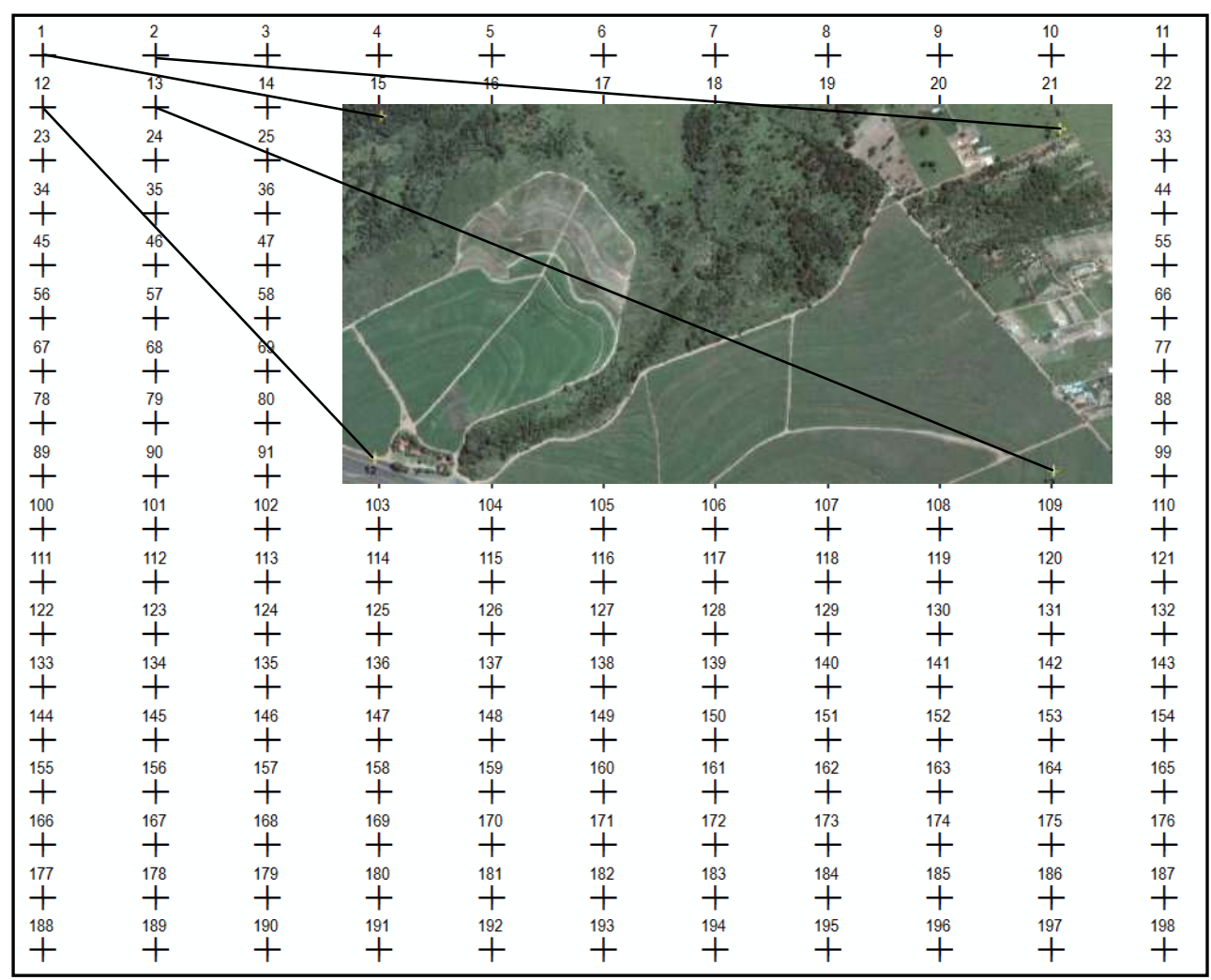

Figura 14: Malha de pontos no software ArcGis $10.3^{\circledR}$, em detalhe a imagem 1. 


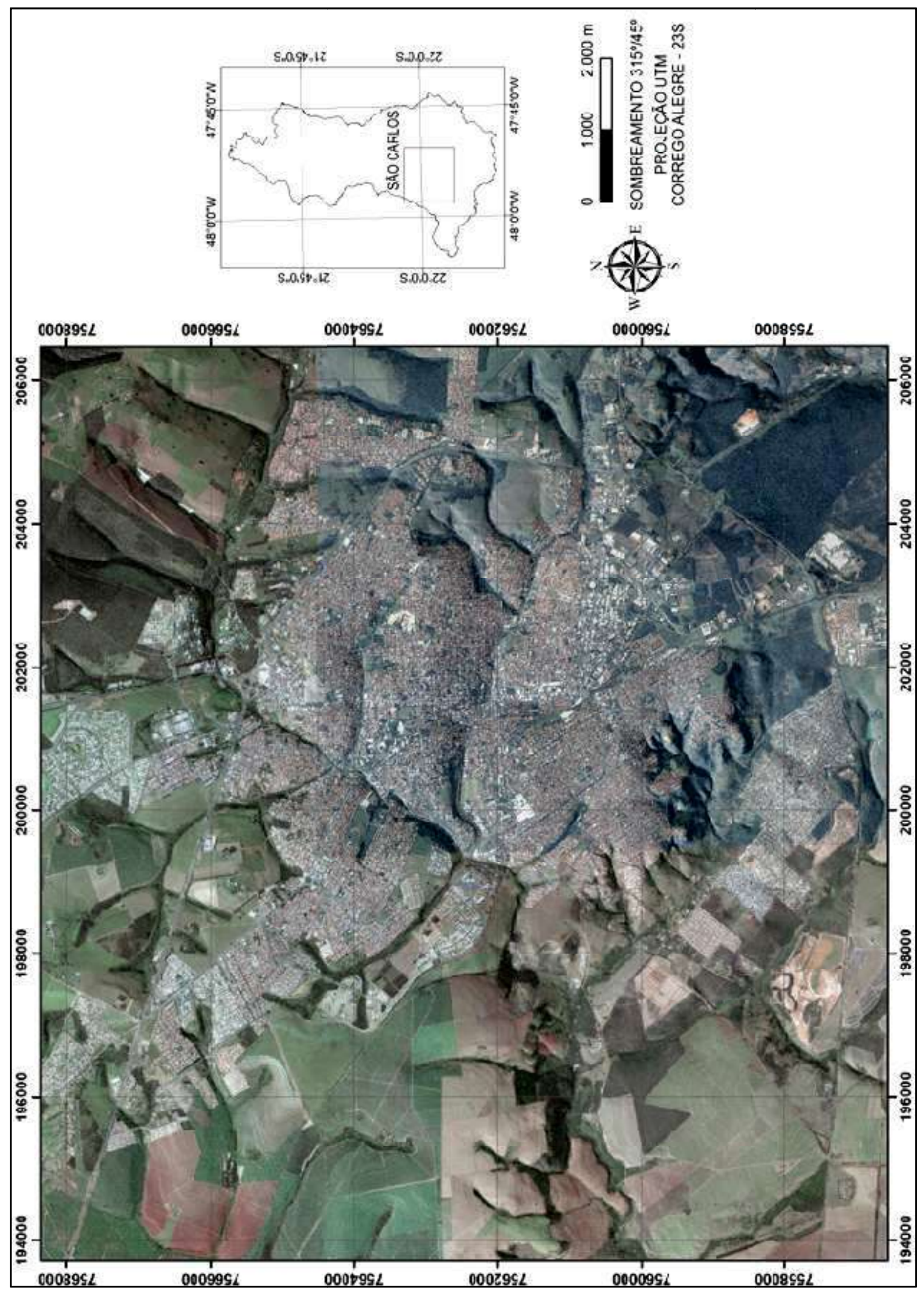

Figura 15: Mosaico de imagens de satélite entre os anos 2014 e 2016, obtidas a partir do Google Earth Pro ${ }^{\circledR}$. 
6.1.2 Modelo digital de terreno

O Modelo digital do terreno (Figura 16) foi gerado a partir de curvas de nível, pontos cotados e a rede de drenagens, resultando em altitudes de 658 até 935 metros. Após, fez-se a validação deste MDT, pelo método qualitativo.

O MDT foi dividido em 5 classes usando o "natural breaks", com a intenção de se ter uma noção das altitudes predominantes da área. Como é observado na Tabela 12 as altitudes maiores são dominantes na região, onde mais de 50\% da área possui elevações entre 827 metros a 935 metros.

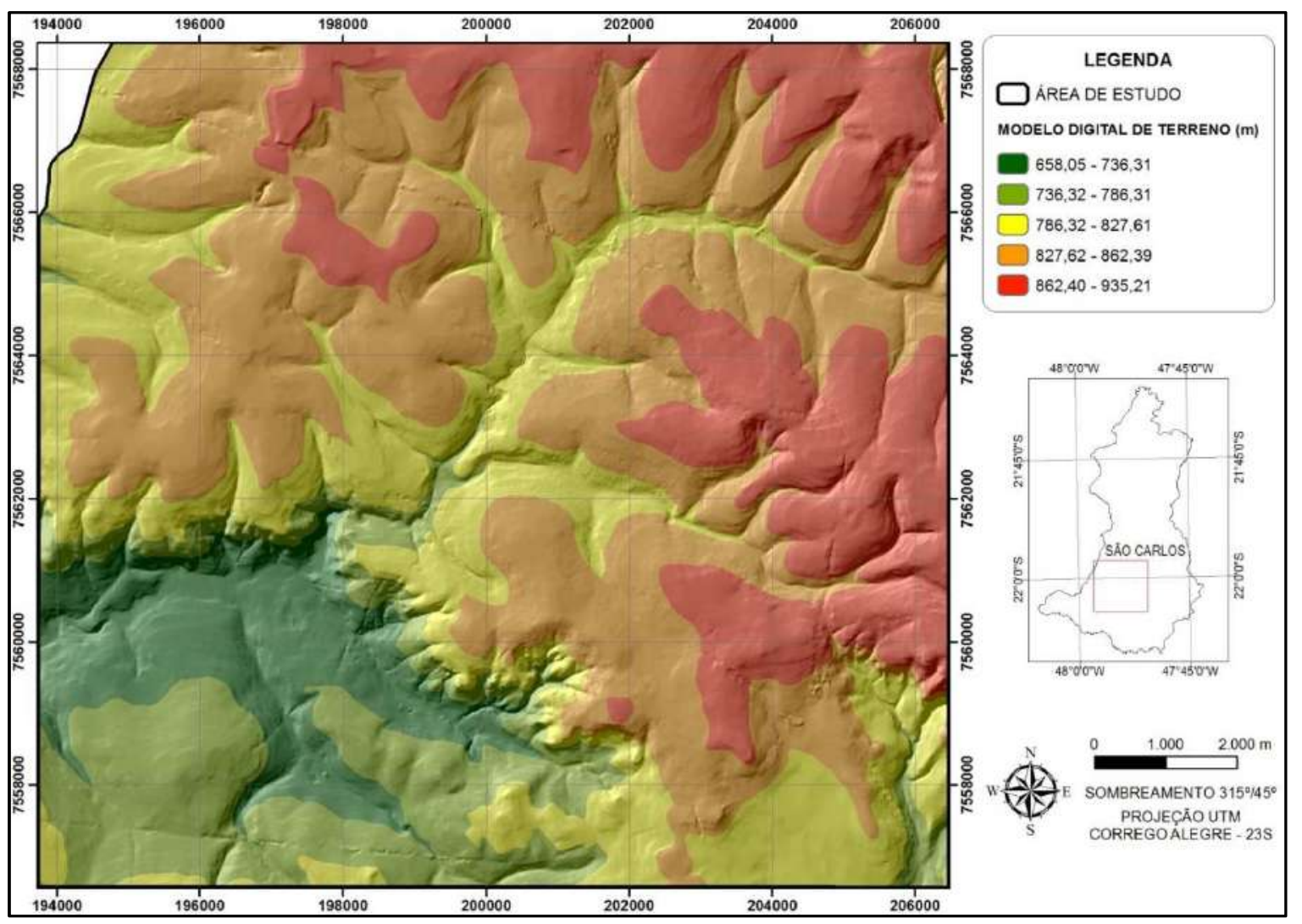

Figura 16: Modelo digital de terreno (MDT) da área de estudos.

Tabela 12: Elevações presentes na área e suas respectivas áreas e porcentagens de ocupação.

\begin{tabular}{c|c|c}
\hline Altitudes $(\mathbf{m})$ & Área $\left(\mathbf{K m}^{\mathbf{2}}\right)$ & $\mathbf{\%}$ \\
\hline $658,05-736,31$ & 13,83 & 9,28 \\
\hline $736,31-786,31$ & 19,35 & 12,99 \\
\hline $786,31-827,61$ & 32,28 & 21,67 \\
\hline $827,61-862,39$ & 53,00 & 35,58 \\
\hline $862,39-935,21$ & 30,52 & 20,49 \\
\hline Total & 148,97 & 100,00 \\
\hline
\end{tabular}


6.1.3 Dados de ensaios geotécnicos

Aguiar (1989) e Bartolomeu (2012) realizaram ensaios ${ }^{1}$ de granulometria e índices físicos, referentes a várias amostras coletadas na área de estudo, cujos os resultados são sintetizados a seguir:

Compartimento Botucatu - composto por arenitos quartzosos com teor de finos variando de baixo a incipiente e geralmente foscos, há também a presença de alguns minerais máficos, presença de solo residual maduro. Os ensaios de granulometria e índices físicos, referentes a este compartimento são expostos nas Tabelas 13 e 14 respectivamente.

Compartimento Serra Geral - composto por basaltos de textura afanítica fina, em alguns pontos com disjunção colunar, diques de diabásio fanerítico fino a médio e intrusivas básicas correlatas a esta Formação, há também a presença de solos residuais maduros. Os ensaios de granulometria e índices físicos, referentes a este compartimento são expostos nas Tabelas 15 e 16 respectivamente.

Compartimento Itaqueri - composto por arenitos com tons vermelho escuro a marrom, seu solo,contém camadas distintas, com porções mais silto argilosas e outras mais arenosas. Os ensaios de granulometria e índices físicos, referentes a este compartimento são expostos nas Tabelas 17 e 18 respectivamente.

Compartimento Aluvionar - constituído predominantemente por material de textura arenosa, texturalmente imatura, e saturada com ocorrência relacionada a planícies de inundação e margens do rio Monjolinho. Os ensaios de granulometria e índices físicos, referentes a este compartimento são expostos nas Tabela 19 e 20 respectivamente.

Compartimento Coluvionar - compartimento composto por grãos de quartzo foscos e bem arredondados referentes a Formação Botucatu e grãos de quartzo relacionados a Formação Itaqueri. Não há dados de ensaios nos trabalhos mencionados para este compartimento.

\footnotetext{
${ }^{1}$ Os pontos com as iniciais "RA" foram amostrados por Aguiar (1989), enquanto que os com a inicial "B" por Bartolomeu (2012).
} 
Tabela 13: Ensaios de granulometria, Compartimento Botucatu. (Aguiar, 1989 e Bartolomeu, 2012).

\begin{tabular}{|c|c|c|c|c|c|c|c|c|c|}
\hline \multirow{2}{*}{ Ponto } & \multicolumn{2}{|c|}{ Coordenadas } & \multirow{2}{*}{ Profundidade (m) } & \multicolumn{6}{|c|}{ Granulometria - ABNT (\%) } \\
\hline & $\mathbf{X}$ & $\mathbf{Y}$ & & Pedr. & Ar. Grossa & Ar. Média & Ar. Fina & Silte & Argila \\
\hline RA014 & 196043 & 7560425 & 0,80 & 0,00 & 0,10 & 27,50 & 60,80 & 3,90 & 7,70 \\
\hline RA025 & 197767 & 7558262 & 0,80 & 0,00 & 0,90 & 26,10 & 60,80 & 3,60 & 8,60 \\
\hline RA027 & 198083 & 7559955 & 0,80 & 0,00 & 0,20 & 16,60 & 73,10 & 3,30 & 6,80 \\
\hline RA035 & 196962 & 7559137 & 0,80 & 0,00 & 0,10 & 25,70 & 61,20 & 4,20 & 8,70 \\
\hline RA042 & 197107 & 7557171 & 1,00 & 0,00 & 0,30 & 18,30 & 65,40 & 3,20 & 12,70 \\
\hline RA047 & 197714 & 7558086 & 1,00 & 0,00 & 0,70 & 31,70 & 56,40 & 2,40 & 8,90 \\
\hline RA060 & 199653 & 7557021 & 0,80 & 0,00 & 0,40 & 14,10 & 52,70 & 8,00 & 24,90 \\
\hline RA062 & 199064 & 7557694 & 0,80 & 0,00 & 0,40 & 18,20 & 62,30 & 5,90 & 13,20 \\
\hline RA074 & 200647 & 7557831 & 0,80 & 0,00 & 0,20 & 19,10 & 67,90 & 2,30 & 10,50 \\
\hline RA083 & 199715 & 7558675 & 1,00 & 0,00 & 0,40 & 15,60 & 73,00 & 4,40 & 6,60 \\
\hline RA159 & 203598 & 7557356 & 0,80 & 0,00 & 0,00 & 14,60 & 77,50 & 3,50 & 4,50 \\
\hline RA191 & 205468 & 7557400 & 0,80 & 0,00 & 0,00 & 8,30 & 73,50 & 5,00 & 13,20 \\
\hline RA246 & 206074 & 7558108 & 1,00 & 0,00 & 0,10 & 8,60 & 73,40 & 7,20 & 10,60 \\
\hline RA747 & 198558 & 7558737 & 0,80 & 0,00 & 0,30 & 13,20 & 78,80 & 2,30 & 5,40 \\
\hline RA753 & 198928 & 7557008 & 2,00 & 0,00 & 0,00 & 5,30 & 23,50 & 17,60 & 53,60 \\
\hline RA760 & 205881 & 7556718 & 2,00 & 0,00 & 0,00 & 9,60 & 81,70 & 3,50 & 5,20 \\
\hline RA770 & 196293 & 7558635 & 0,80 & 0,00 & 0,30 & 23,40 & 68,70 & 3,10 & 4,50 \\
\hline B187 & 202379 & 7556939 & - & 0,00 & 8,00 & 50,00 & 24,00 & 18,00 & 0,00 \\
\hline
\end{tabular}

Tabela 14: Ensaios de índices físicos, Compartimento Botucatu. (Aguiar, 1989 e Bartolomeu, 2012)

\begin{tabular}{|c|c|c|c|c|c|c|c|c|c|c|}
\hline \multirow{2}{*}{ Ponto } & \multirow{2}{*}{ Profundidade (m) } & \multicolumn{3}{|c|}{ Massa Específica $\left(\mathrm{g} / \mathrm{cm}^{3}\right)$} & \multirow{2}{*}{ Índice de vazios } & \multicolumn{2}{|c|}{ Umidade (\%) } & \multicolumn{3}{|c|}{ Limites de Attemberg (\%) } \\
\hline & & Sólido & Seca & Solo & & Natural & Higroscópica & $\mathbf{L L}$ & $\mathbf{L P}$ & IP \\
\hline RA014 & 0,80 & 2,631 & 1,554 & 1,711 & 0,693 & 10,10 & 2,10 & $\mathrm{np}$ & $\mathrm{np}$ & $\mathrm{np}$ \\
\hline RA025 & 0,80 & 2,655 & ne & ne & ne & 7,30 & 2,00 & $\mathrm{np}$ & $\mathrm{np}$ & $\mathrm{np}$ \\
\hline RA027 & 0,80 & 2,636 & 1,416 & 1,533 & 0,862 & 8,20 & 1,50 & $\mathrm{np}$ & np & $\mathrm{np}$ \\
\hline RA035 & 0,80 & 2,669 & ne & ne & ne & 8,50 & 2,60 & $\mathrm{np}$ & $\mathrm{np}$ & $\mathrm{np}$ \\
\hline RA042 & 1,00 & 2,641 & 1,500 & 1,635 & 0,761 & 9,00 & 2,10 & $\mathrm{np}$ & $\mathrm{np}$ & $\mathrm{np}$ \\
\hline 4A047 & 1,00 & 2,648 & 1,649 & 1,739 & 0,606 & 5,40 & 1,70 & $\mathrm{np}$ & np & $\mathrm{np}$ \\
\hline RA060 & 0,80 & 2,716 & 1,590 & 1,834 & 0,708 & 15,40 & 6,10 & 32,40 & 23,80 & 8,60 \\
\hline RA062 & 0,80 & 2,655 & ne & ne & ne & 9,60 & 4,40 & $\mathrm{np}$ & $\mathrm{np}$ & $\mathrm{np}$ \\
\hline RA074 & 0,80 & 2,620 & 1,598 & 1,710 & 0,640 & 7,00 & 2,80 & $\mathrm{np}$ & $\mathrm{np}$ & $\mathrm{np}$ \\
\hline RA083 & 1,00 & 2,631 & 1,606 & 1,731 & 0,638 & 7,80 & 1,10 & $\mathrm{np}$ & $\mathrm{np}$ & $\mathrm{np}$ \\
\hline RA159 & 0,80 & 2,623 & ne & ne & ne & 5,80 & 1,10 & $\mathrm{np}$ & $\mathrm{np}$ & $\mathrm{np}$ \\
\hline RA191 & 0,80 & 2,623 & 1,548 & 1,695 & 0,694 & 9,50 & 3,00 & $\mathrm{np}$ & $\mathrm{np}$ & $\mathrm{np}$ \\
\hline RA246 & 1,00 & 2,648 & 1,522 & 1,669 & 0,740 & 9,70 & 2,50 & $\mathrm{np}$ & $\mathrm{np}$ & $\mathrm{np}$ \\
\hline RA747 & 0,80 & 2,627 & ne & ne & ne & 7,00 & 2,10 & $\mathrm{np}$ & $\mathrm{np}$ & $\mathrm{np}$ \\
\hline RA753 & 2,00 & 2,928 & 1,407 & 1,611 & 1,081 & 14,50 & 13,40 & 46,70 & 35,50 & 11,20 \\
\hline RA760 & 2,00 & 2,663 & ne & ne & ne & 4,60 & 0,80 & $\mathrm{np}$ & $\mathrm{np}$ & $\mathrm{np}$ \\
\hline RA770 & 0,80 & 2,629 & ne & ne & ne & 8,00 & 3,00 & $\mathrm{np}$ & $\mathrm{np}$ & $\mathrm{np}$ \\
\hline B187 & - & 2,687 & 1,794 & 1,885 & 0,500 & & $5,07 *$ & 28,00 & 17,00 & 11,00 \\
\hline
\end{tabular}


Tabela 15: Ensaios de granulometria, Compartimento Serra Geral. (Aguiar, 1989 e Bartolomeu, 2012)

\begin{tabular}{c|c|c|c|c|c|c|c|c|c}
\hline \multirow{2}{*}{ Ponto } & \multicolumn{2}{|c|}{ Coordenadas } & \multirow{2}{*}{ Profundidade $(\mathbf{m})$} & \multicolumn{5}{|c}{ Granulometria - ABNT $(\%)$} \\
\cline { 7 - 10 } & $\mathbf{X}$ & $\mathbf{Y}$ & & Pedr. & Ar. Grossa & Ar. Média & Ar. Fina & Silte & Argila \\
\hline RA017 & 198528 & 7560645 & 0,80 & 0,00 & 0,10 & 1,10 & 52,80 & 16,50 & 29,50 \\
\hline RA077 & 199086 & 7559959 & 0,80 & 0,40 & 0,10 & 2,60 & 26,80 & 24,80 & 45,20 \\
\hline RA108 & 198127 & 7561419 & 0,80 & 0,90 & 1,20 & 4,90 & 31,20 & 35,80 & 26,00 \\
\hline RA741 & 199205 & 7562053 & 0,80 & 0,00 & 0,00 & 3,70 & 20,70 & 26,60 & 50,00 \\
\hline B126 & 202533 & 7561799 & 0,20 & 0,30 & 0,70 & 9,00 & 15,00 & 30,00 & 45,00 \\
\hline
\end{tabular}

Tabela 16: Ensaios de índices físicos, Compartimento Serra Geral. (Aguiar, 1989 e Bartolomeu, 2012).

\begin{tabular}{|c|c|c|c|c|c|c|c|c|c|c|}
\hline \multirow{2}{*}{ Ponto } & \multirow{2}{*}{$\begin{array}{l}\text { Profundidade } \\
\text { (m) }\end{array}$} & \multicolumn{3}{|c|}{ Massa Específica $\left(\mathrm{g} / \mathrm{cm}^{3}\right)$} & \multirow{2}{*}{ Índice de vazios } & \multicolumn{2}{|c|}{ Umidade (\%) } & \multicolumn{3}{|c|}{ Limites de Attemberg (\%) } \\
\hline & & Sólido & Seca & Solo & & Natural & Higroscópica & $\mathbf{L L}$ & LP & IP \\
\hline RA017 & 0,80 & 2,765 & 1,340 & 1,593 & 1,063 & 18,90 & 10,10 & 30,10 & 21,20 & 9,00 \\
\hline RA077 & 0,80 & 3,004 & 1,375 & 1,774 & 1,185 & 29,00 & 17,70 & 42,40 & 33,00 & 9,40 \\
\hline RA108 & 0,80 & 2,840 & ne & ne & ne & 25,00 & 14,40 & 37,60 & 29,70 & 7,90 \\
\hline RA741 & 0,80 & 2,946 & 1,372 & 1,711 & 1,147 & 24,70 & 14,40 & 42,30 & 32,90 & 9,40 \\
\hline B126 & 0,20 & 3,042 & 1,298 & 1,572 & 1,340 & & $21,08 *$ & 49,00 & 33,00 & 16,00 \\
\hline
\end{tabular}

Tabela 17: Ensaios de granulometria, Compartimento Itaqueri. (Aguiar, 1989 e Bartolomeu, 2012)

\begin{tabular}{|c|c|c|c|c|c|c|c|c|c|}
\hline \multirow{2}{*}{ Ponto } & \multicolumn{2}{|c|}{ Coordenadas } & \multirow{2}{*}{ Profundidade (m) } & \multicolumn{6}{|c|}{ Granulometria - ABNT (\%) } \\
\hline & $\mathbf{X}$ & $\mathbf{Y}$ & & Pedr. & Ar. Grossa & Ar. Média & Ar. Fina & Silte & Argila \\
\hline RA003 & 197147 & 7563522 & 0,80 & 0,00 & 0,00 & 15,90 & 44,90 & 6,30 & 32,90 \\
\hline RA005 & 197446 & 7562127 & 0,80 & 0,00 & 0,00 & 4,80 & 22,90 & 23,60 & 48,70 \\
\hline RA124 & 196381 & 7563728 & 0,80 & 0,00 & 0,00 & 15,00 & 47,40 & 9,20 & 28,30 \\
\hline RA132 & 197912 & 7562330 & 0,80 & 0,00 & 0,10 & 10,70 & 37,60 & 15,30 & 36,30 \\
\hline RA309 & 205907 & 7562268 & 0,80 & 0,00 & 0,00 & 10,20 & 44,00 & 10,80 & 35,00 \\
\hline RA316 & 205745 & 7564120 & 0,80 & 0,00 & 0,00 & 13,40 & 52,80 & 6,40 & 27,40 \\
\hline RA434 & 204109 & 7567678 & 0,80 & 0,00 & 0,00 & 30,80 & 45,60 & 4,60 & 18,90 \\
\hline RA446 & 202363 & 7567752 & 1,50 & 0,00 & 0,00 & 11,20 & 40,60 & 15,00 & 33,10 \\
\hline RA447 & 202657 & 7566921 & 0,80 & 0,00 & 0,10 & 19,80 & 41,60 & 7,10 & 31,40 \\
\hline RA478 & 206400 & 7567876 & 1,00 & 0,00 & 0,20 & 12,30 & 51,50 & 7,60 & 28,40 \\
\hline RA492 & 206387 & 7565993 & 0,80 & 0,00 & 0,00 & 10,90 & 40,70 & 9,50 & 38,90 \\
\hline RA527 & 204117 & 7566231 & 0,80 & 0,00 & 0,10 & 6,90 & 58,50 & 13,60 & 20,90 \\
\hline RA533 & 203418 & 7565927 & 2,00 & 0,00 & 0,90 & 4,10 & 24,40 & 27,80 & 42,70 \\
\hline RA540 & 204597 & 7563953 & 0,80 & 0,00 & 0,10 & 12,70 & 56,20 & 11,80 & 19,20 \\
\hline RA546 & 204368 & 7565474 & 1,00 & 0,20 & 0,60 & 9,40 & 24,10 & 22,20 & 43,40 \\
\hline RA557 & 204966 & 7562453 & 5,20 & 0,00 & 0,20 & 11,00 & 42,60 & 22,30 & 23,80 \\
\hline RA564 & 201800 & 7566446 & 0,80 & 0,00 & 0,00 & 4,50 & 32,10 & 21,40 & 42,00 \\
\hline RA578 & 199952 & 7568157 & 0,80 & 0,00 & 0,20 & 18,40 & 42,60 & 9,30 & 29,50 \\
\hline RA621 & 198611 & 7566605 & 0,80 & 0,00 & 0,10 & 12,20 & 51,00 & 9,60 & 27,10 \\
\hline RA625 & 196223 & 7567924 & 0,80 & 0,00 & 0,10 & 16,00 & 54,70 & 7,40 & 21,80 \\
\hline RA645 & 197586 & 7567343 & 0,80 & 0,00 & 0,10 & 12,10 & 47,30 & 14,50 & 26,00 \\
\hline RA655 & 199372 & 7567357 & 0,80 & 0,00 & 0,00 & 12,20 & 45,80 & 9,60 & 32,50 \\
\hline RA662 & 199579 & 7566605 & 0,80 & 0,00 & 0,00 & 9,20 & 47,40 & 12,80 & 30,50 \\
\hline
\end{tabular}


Tabela 17 continuação: Ensaios de granulometria, Compartimento Itaqueri. (Aguiar, 1989 e Bartolomeu, 2012).

\begin{tabular}{|c|c|c|c|c|c|c|c|c|c|}
\hline \multirow{2}{*}{ Ponto } & \multicolumn{2}{|c|}{ Coordenadas } & \multirow{2}{*}{ Profundidade (m) } & \multicolumn{6}{|c|}{ Granulometria - ABNT (\%) } \\
\hline & $\mathbf{X}$ & $\mathbf{Y}$ & & Pedr. & Ar. Grossa & Ar. Média & Ar. Fina & Silte & Argila \\
\hline RA665 & 197142 & 7566802 & 0,80 & 0,00 & 0,00 & 12,30 & 46,50 & 10,20 & 31,00 \\
\hline RA667 & 198050 & 7565762 & 1,00 & 0,00 & 0,00 & 14,30 & 42,60 & 10,80 & 32,20 \\
\hline RA671 & 201008 & 7567651 & 0,80 & 0,00 & 0,30 & 15,10 & 45,20 & 15,20 & 24,20 \\
\hline RA704 & 196201 & 7566099 & 0,80 & 0,00 & 0,10 & 14,80 & 50,80 & 9,80 & 24,50 \\
\hline RA709 & 196689 & 7565936 & 0,80 & 0,00 & 0,00 & 14,30 & 51,50 & 15,90 & 18,30 \\
\hline RA710 & 196386 & 7565140 & 0,80 & 0,00 & 0,30 & 12,70 & 46,50 & 9,70 & 30,90 \\
\hline RA717 & 199086 & 7565633 & 0,80 & 0,00 & 0,30 & 9,90 & 49,80 & 11,30 & 28,60 \\
\hline RA720 & 199702 & 7565575 & 0,80 & 0,00 & 0,00 & 15,30 & 50,40 & 17,60 & 16,70 \\
\hline RA724 & 197644 & 7564784 & 0,80 & 0,00 & 0,10 & 14,50 & 47,00 & 17,30 & 21,10 \\
\hline RA726 & 196663 & 7564515 & 0,80 & 0,00 & 0,00 & 15,50 & 48,10 & 15,50 & 20,90 \\
\hline RA727 & 197617 & 7563873 & 0,80 & 0,00 & 0,10 & 28,30 & 42,10 & 8,70 & 20,80 \\
\hline RA731 & 198013 & 7562871 & 0,80 & 0,00 & 0,10 & 13,00 & 54,60 & 10,90 & 21,40 \\
\hline RA734 & 199117 & 7563135 & 0,80 & 0,00 & 0,10 & 13,60 & 46,10 & 20,00 & 20,20 \\
\hline RA736 & 198514 & 7562756 & 0,80 & 0,00 & 0,10 & 13,40 & 40,00 & 13,50 & 33,10 \\
\hline RA738 & 197762 & 7563319 & 0,80 & 0,00 & 0,10 & 15,80 & 55,20 & 6,90 & 22,00 \\
\hline RA743 & 197028 & 7561564 & 0,80 & 2,00 & 3,50 & 6,60 & 36,30 & 40,50 & 11,10 \\
\hline RA761 & 206132 & 7564995 & 0,80 & 0,00 & 0,30 & 6,40 & 30,10 & 15,80 & 47,70 \\
\hline RA764 & 205124 & 7567299 & 0,80 & 0,00 & 0,80 & 11,50 & 37,60 & 10,00 & 40,10 \\
\hline RA769 & 196526 & 7567079 & 0,80 & 0,00 & 0,00 & 15,20 & 43,70 & 10,60 & 30,50 \\
\hline RA774 & 202116 & 7565540 & 0,80 & 0,00 & 0,00 & 13,10 & 54,60 & 15,30 & 17,00 \\
\hline RA775 & 202780 & 7565316 & 0,80 & 0,00 & 0,00 & 15,40 & 57,10 & 7,80 & 19,70 \\
\hline RA779 & 197432 & 7562611 & 0,80 & 0,00 & 0,00 & 12,60 & 45,60 & 10,60 & 31,20 \\
\hline 7 & 204588 & 7565440 & - & 0,00 & 0,50 & 22,30 & 18,20 & 18,60 & 40,40 \\
\hline 6 & 204588 & 7565440 & 2,00 & & 0,40 & 8,00 & 10,60 & 36,00 & 45,00 \\
\hline
\end{tabular}

Tabela 18: Ensaios de índices físicos, Compartimento Itaqueri. (Aguiar, 1989 e Bartolomeu, 2012).

\begin{tabular}{|c|c|c|c|c|c|c|c|c|c|c|}
\hline \multirow{2}{*}{ Ponto } & \multirow{2}{*}{$\begin{array}{c}\text { Profundidade } \\
(\mathbf{m})\end{array}$} & \multicolumn{3}{|c|}{ Massa Específica $\left(\mathrm{g} / \mathrm{cm}^{3}\right)$} & \multirow{2}{*}{ Índice de vazios } & \multicolumn{2}{|c|}{ Umidade (\%) } & \multicolumn{3}{|c|}{ Limites de Attemberg (\%) } \\
\hline & & Sólido & Seca & Solo & & Natural & Higroscópica & $\mathbf{L L}$ & LP & IP \\
\hline RA003 & 0,80 & 2,693 & 1,208 & 1,471 & 1,229 & 21,80 & 8,70 & 30,30 & 24,80 & 5,50 \\
\hline RA005 & 0,80 & 2,899 & 1,128 & 1,419 & 1,570 & 25,80 & 12,70 & 41,90 & 30,80 & 11,10 \\
\hline RA124 & 0,80 & 2,661 & ne & ne & ne & 17,60 & 9,10 & 33,00 & 22,80 & 10,20 \\
\hline RA132 & 0,80 & 2,739 & 1,449 & 1,742 & 0,890 & 20,20 & 9,80 & 30,70 & 19,10 & 11,60 \\
\hline RA309 & 0,80 & 2,694 & 1,577 & 1,870 & 0,708 & 18,60 & 13,80 & 30,60 & 23,10 & 7,50 \\
\hline RA316 & 0,80 & 2,647 & 1,384 & 1,586 & 0,913 & 14,60 & 9,90 & $\mathrm{np}$ & np & np \\
\hline RA434 & 0,80 & 2,631 & 1,404 & 1,680 & 0,874 & 19,70 & 10,00 & $\mathrm{np}$ & $\mathrm{np}$ & $\mathrm{np}$ \\
\hline RA446 & 1,50 & 2,724 & 1,242 & 1,537 & 1,193 & 23,80 & 16,80 & 33,70 & 27,10 & 6,60 \\
\hline RA447 & 0,80 & 2,629 & 1,439 & 1,725 & 0,827 & 19,90 & 11,40 & 31,30 & 22,00 & 9,30 \\
\hline RA478 & 1,00 & 2,670 & ne & ne & ne & 17,30 & 9,90 & 30,20 & 20,20 & 10,00 \\
\hline RA492 & 0,80 & 2,670 & ne & ne & ne & 20,80 & 12,40 & 35,90 & 25,50 & 10,40 \\
\hline RA527 & 0,80 & 2,656 & ne & ne & ne & 15,50 & 8,40 & 25,60 & 16,90 & 8,80 \\
\hline RA533 & 2,00 & 2,906 & 1,309 & 1,701 & 1,220 & 29,90 & 27,10 & 53,30 & 40,40 & 12,90 \\
\hline RA540 & 0,80 & 2,682 & 1,641 & 1,880 & 0,634 & 14,60 & 13,40 & $\mathrm{np}$ & $\mathrm{np}$ & $\mathrm{np}$ \\
\hline RA546 & 1,00 & 2,864 & ne & ne & ne & 30,10 & 23,50 & 48,90 & 34,80 & 14,10 \\
\hline RA557 & 5,20 & 2,669 & 1,397 & 1,680 & 0,911 & 20,30 & 9,20 & 37,40 & 28,10 & 9,30 \\
\hline RA564 & 0,80 & 2,867 & 1,227 & 1,555 & 1,337 & 26,70 & 15,00 & 44,20 & 35,30 & 8,90 \\
\hline
\end{tabular}


Tabela 18 continuação: Ensaios de índices físicos, Compartimento Itaqueri. (Aguiar, 1989 e Bartolomeu, 2012).

\begin{tabular}{|c|c|c|c|c|c|c|c|c|c|c|}
\hline \multirow{2}{*}{ Ponto } & \multirow{2}{*}{$\begin{array}{l}\text { Profundidade } \\
\text { (m) }\end{array}$} & \multicolumn{3}{|c|}{ Massa Específica $\left(\mathrm{g} / \mathrm{cm}^{3}\right)$} & \multirow{2}{*}{ Índice de vazios } & \multicolumn{2}{|c|}{ Umidade (\%) } & \multicolumn{3}{|c|}{ Limites de Attemberg (\%) } \\
\hline & & Sólido & Seca & Solo & & Natural & Higroscópica & $\mathbf{L L}$ & $\mathbf{L P}$ & IP \\
\hline RA578 & 0,80 & 2,660 & 1,383 & 1,589 & 0,923 & 14,90 & 8,60 & 31,20 & 25,00 & 6,20 \\
\hline RA621 & 0,80 & 2,636 & ne & ne & ne & 18,00 & 9,60 & 39,70 & 27,00 & 12,70 \\
\hline RA625 & 0,80 & 2,659 & 1,486 & 1,727 & 0,789 & 16,20 & 5,10 & $\mathrm{np}$ & $\mathrm{np}$ & np \\
\hline RA645 & 0,80 & 2,680 & ne & ne & ne & 15,70 & 8,90 & 31,90 & 23,90 & 8,00 \\
\hline RA655 & 0,80 & 2,668 & ne & ne & ne & 15,10 & 8,50 & 32,20 & 23,70 & 8,50 \\
\hline RA662 & 0,80 & 2,781 & ne & ne & ne & 23,10 & 13,90 & $\mathrm{np}$ & $\mathrm{np}$ & np \\
\hline RA665 & 0,80 & 2,650 & 1,352 & 1,591 & 0,960 & 17,70 & 11,30 & 30,90 & 24,90 & 6,00 \\
\hline RA667 & 1,00 & 2,682 & 1,306 & 1,546 & 1,054 & 18,40 & 11,80 & $\mathrm{np}$ & $\mathrm{np}$ & $\mathrm{np}$ \\
\hline RA671 & 0,80 & 2,617 & ne & ne & ne & 16,40 & 8,90 & 29,40 & 21,10 & 8,30 \\
\hline RA704 & 0,80 & 2,665 & ne & ne & ne & 18,90 & 10,30 & 28,20 & 24,10 & 4,10 \\
\hline RA709 & 0,80 & 2,673 & ne & ne & $\mathrm{Ne}$ & 14,70 & 7,40 & 27,40 & 21,00 & 6,40 \\
\hline RA710 & 0,80 & 2,663 & 1,410 & 1,688 & 0,889 & 19,70 & 12,60 & 36,70 & 28,30 & 8,40 \\
\hline RA717 & 0,80 & 2,687 & 1,301 & 1,562 & 1,065 & 20,00 & 7,30 & 42,00 & 27,70 & 14,30 \\
\hline RA720 & 0,80 & 2,666 & ne & ne & $\mathrm{Ne}$ & 16,10 & 8,80 & 35,80 & 25,40 & 10,40 \\
\hline RA724 & 0,80 & 2,663 & ne & ne & $\mathrm{Ne}$ & 18,30 & 10,80 & 31,80 & 25,60 & 6,20 \\
\hline RA726 & 0,80 & 2,642 & ne & ne & $\mathrm{Ne}$ & 20,20 & 12,30 & 33,30 & 26,10 & 7,20 \\
\hline RA727 & 0,80 & 2,562 & 1,572 & 2,317 & 0,630 & 13,50 & 9,20 & $\mathrm{np}$ & $\mathrm{np}$ & $\mathrm{np}$ \\
\hline RA731 & 0,80 & 2,658 & ne & ne & $\mathrm{Ne}$ & 16,00 & 8,80 & 30,20 & 19,60 & 10,60 \\
\hline RA734 & 0,80 & 2,703 & 1,403 & 1,685 & 0,927 & 20,10 & 11,40 & 34,40 & 24,30 & 10,10 \\
\hline RA736 & 0,80 & 2,739 & 1,649 & 1,860 & 0,661 & 12,80 & 11,40 & 32,80 & 23,80 & 9,00 \\
\hline RA738 & 0,80 & 2,667 & 1,459 & 1,733 & 0,828 & 18,80 & 7,20 & 30,60 & 21,40 & 9,20 \\
\hline RA743 & 0,80 & 2,871 & ne & ne & $\mathrm{Ne}$ & 38,50 & 25,50 & 49,30 & 40,10 & 9,20 \\
\hline RA761 & 0,80 & 2,784 & ne & ne & $\mathrm{Ne}$ & 29,60 & 23,40 & 46,10 & 30,20 & 15,90 \\
\hline RA764 & 0,80 & 2,667 & ne & ne & $\mathrm{Ne}$ & 19,40 & 10,70 & 40,10 & 26,90 & 13,20 \\
\hline RA769 & 0,80 & 2,656 & ne & ne & $\mathrm{Ne}$ & 16,50 & 8,60 & $\mathrm{np}$ & $\mathrm{np}$ & $\mathrm{np}$ \\
\hline RA774 & 0,80 & 2,677 & 1,429 & 1,624 & 0,873 & 13,70 & 7,90 & $\mathrm{np}$ & $\mathrm{np}$ & $\mathrm{np}$ \\
\hline RA775 & 0,80 & 2,665 & 1,428 & 1,623 & 0,866 & 13,70 & 7,30 & 25,70 & 19,00 & 6,70 \\
\hline RA779 & 0,80 & 2,649 & ne & ne & $\mathrm{Ne}$ & 18,00 & 9,90 & 31,80 & 25,10 & 6,70 \\
\hline 7 & - & 2,801 & 1,742 & 2,014 & 0,61 & & $15,66^{*}$ & 53,00 & 24,00 & 28,00 \\
\hline 6 & 2,00 & 2,997 & 1,527 & 1,990 & 0,960 & & $30,36^{*}$ & 70,00 & 44,00 & 26,00 \\
\hline
\end{tabular}

Tabela 19: Ensaios de granulometria, Compartimento Aluvionar. (Aguiar, 1989 e Bartolomeu, 2012)

\begin{tabular}{c|c|c|c|c|c|c|c|c|c}
\hline \multirow{2}{*}{ Ponto } & \multicolumn{2}{|c|}{ Coordenadas } & \multirow{5}{*}{ Profundidade (m) } & \multicolumn{5}{|c}{ Granulometria - ABNT (\%) } \\
\cline { 2 - 7 } & $\mathbf{X}$ & $\mathbf{Y}$ & & Pedr. & Ar. Grossa & Ar. Média & Ar. Fina & Silte & Argila \\
\hline RA011 & 197600 & 7560808 & 2,00 & 0,60 & 0,90 & 0,90 & 23,70 & 26,60 & 47,80 \\
\hline RA071 & 200691 & 7558367 & 1,80 & 0,00 & 2,70 & 11,10 & 35,90 & 12,40 & 37,90 \\
\hline
\end{tabular}

Tabela 20: : Ensaios de índices físicos, Compartimento Aluvionar. (Aguiar, 1989 e Bartolomeu, 2012)

\begin{tabular}{c|c|c|c|c|c|c|c}
\hline \multirow{2}{*}{ Ponto } & \multirow{2}{*}{ Profundidade $(\mathbf{m})$} & \multicolumn{2}{|c|}{ Massa Específica $\left(\mathbf{g} / \mathrm{cm}^{3}\right)$} & \multirow{2}{*}{ Índice de vazios } & \multicolumn{2}{|c}{ Umidade $(\%)$} \\
\cline { 3 - 5 } & & Sólido & Seca & Solo & & \multirow{2}{*}{ Natural } & \multirow{2}{*}{ Higroscópica } \\
\hline \multirow{2}{*}{ RA011 } & 2,00 & 2,908 & 1,146 & 1,588 & 1,538 & 38,60 & 17,30 \\
\hline RA071 & 1,80 & 2,790 & 1,313 & 1,647 & 1,123 & 25,40 & 11,40 \\
\hline
\end{tabular}




\subsubsection{Dados pluviométricos}

Silva Júnior (2016) em seu trabalho vinculado a esta pesquisa, inventariou os postos pluviométricos do município de São Carlos. Os dados relativos a estes postos e a abrangência de suas séries históricas, bem como a localização dos postos pluviométricos são apresentados na Tabela 21 e na Figura 17 respectivamente.

Tabela 21: Dados dos postos pluviométricos (Silva Júnior, 2016)

\begin{tabular}{c|c|c|c|c|c|c}
\hline Posto Pluviométrico & Município & Prefixo & Altitude $(\mathbf{m})$ & Latitude & Longitude & Abrangência Da Série Histórica \\
\hline Água Vermelha (Cpef) & São Carlos & C4-022 & 800 & $21^{\circ} 53^{\prime} 00^{\prime \prime}$ & $47^{\circ} 53^{\prime} 00^{\prime \prime}$ & $1939-1961$ \\
\hline Fazenda Da Barra & São Carlos & C4-092 & 610 & $21^{\circ} 53^{\prime} 08^{\prime \prime}$ & $47^{\circ} 47^{\prime} 09^{\prime \prime}$ & $1960-2014$ \\
\hline Cabaceiras & São Carlos & C4-101 & 620 & $21^{\circ} 47^{\prime} 00^{\prime \prime}$ & $47^{\circ} 57^{\prime} 00^{\prime \prime}$ & $1972-1996 / 1998-2000$ \\
\hline Vila Carmem & São Carlos & D4-015 & 820 & $22^{\circ} 01^{\prime} 00^{\prime \prime}$ & $47^{\circ} 54^{\prime} 00^{\prime \prime}$ & $1937-1994 / 1997-1998$ \\
\hline São Carlos (Inmet) & São Carlos & D4-017 & 830 & $22^{\circ} 01^{\prime} 00^{\prime \prime}$ & $47^{\circ} 53^{\prime} 00^{\prime \prime}$ & $1954-1971 / 2008-2016$ \\
\hline Monjolinho (Cpef) & São Carlos & D4-045 & 660 & $22^{\circ} 02^{\prime} 00^{\prime \prime}$ & $47^{\circ} 58^{\prime} 00^{\prime \prime}$ & $1940-1968$ \\
\hline São Carlos - Saae & São Carlos & D4-075 & 815 & $21^{\circ} 59^{\prime} 12^{\prime \prime}$ & $47^{\circ} 52^{\prime} 33^{\prime \prime}$ & $1970-1995 / 2014-2015$ \\
\hline Fazenda Santa Bárbara & São Carlos & D4-106 & 789 & $22^{\circ} 05^{\prime} 38^{\prime \prime}$ & $47^{\circ} 58^{\prime} 30^{\prime \prime}$ & $1979-2015$ \\
\hline Fazenda Água Branca & São Carlos & D5-076 & 598 & $22^{\circ} 04^{\prime} 03^{\prime \prime}$ & $48^{\circ} 02^{\prime} 46^{\prime \prime}$ & $1961-2015$ \\
\hline Ibaté & Ibaté & C5-035 & 830 & $21^{\circ} 57^{\prime} 00^{\prime \prime}$ & $48^{\circ} 00^{\prime} 00^{\prime \prime}$ & $1939-1999$ \\
\hline Usina Do Lobo & Itirapina & D4-033 & 690 & $22^{\circ} 10^{\prime} 00^{\prime \prime}$ & $47^{\circ} 54^{\prime} 00^{\prime \prime}$ & $1938-1997$ \\
\hline Visconde De Rio Claro & Itirapina & D4-037 & 760 & $22^{\circ} 08^{\prime} 54^{\prime \prime}$ & $47^{\circ} 47^{\prime} 42^{\prime \prime}$ & $1937-1999 / 2004-2015$ \\
\hline Analândia & Analândia & D4-035 & 643 & $22^{\circ} 07^{\prime} 47^{\prime \prime}$ & $47^{\circ} 40^{\prime} 03^{\prime \prime}$ & $1937-2015$ \\
\hline
\end{tabular}

Os dados referentes a precipitação média anual e as máximas diárias bem como as médias mensais são mostrados nas Tabelas 22 e 23 respectivamente.

Como pode-se observar a média anual histórica para o município de São Carlos varia de 1090,8 mm a 1588,0 mm. Como já era de se esperar os meses mais chuvosos são os do verão, estando de acordo com a classificação Koppen (Cwa) para a região de estudos, o que equivale a um clima temperado úmido, com verão quente e úmido e inverno seco. 


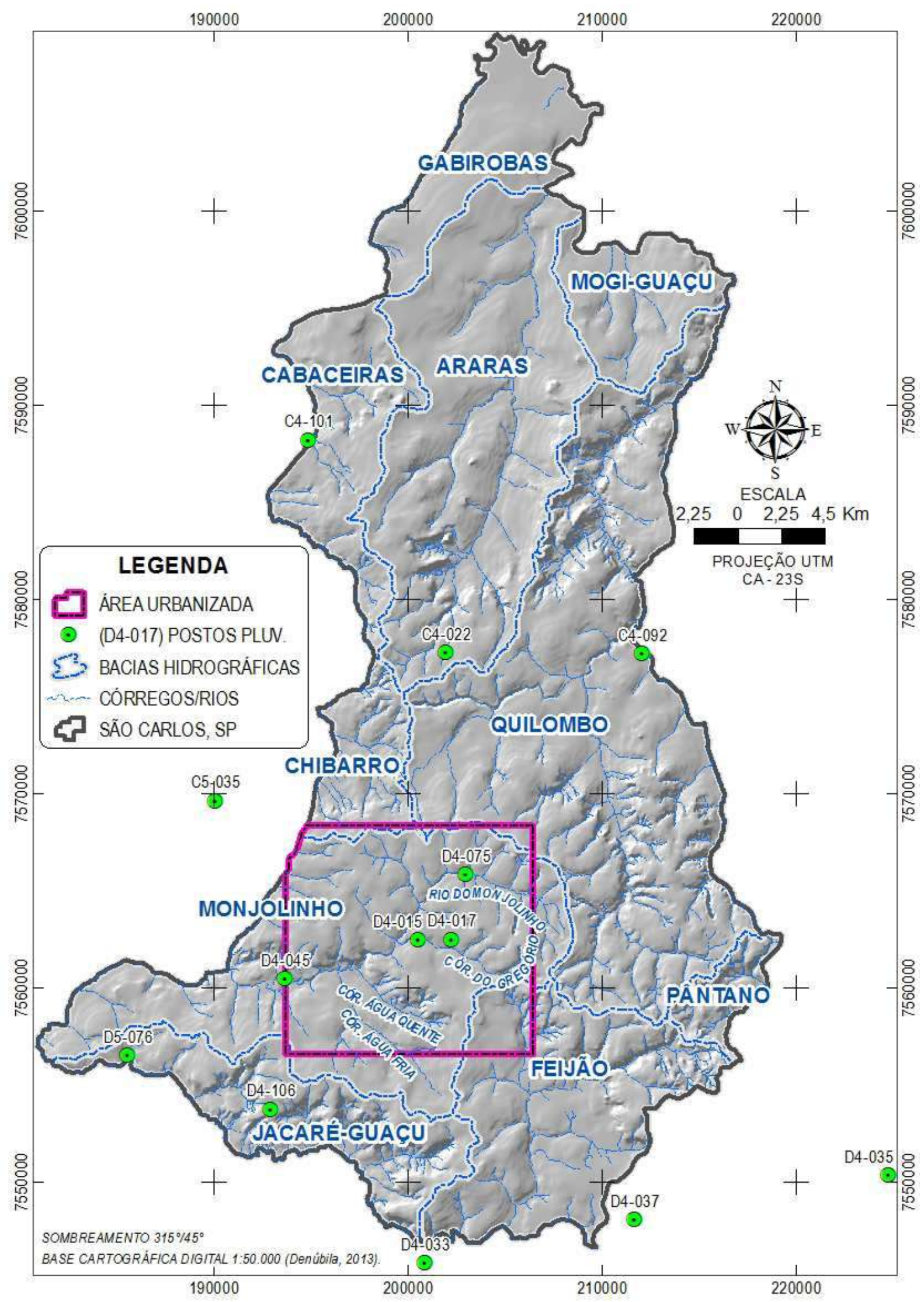

Figura 17: Localização dos postos pluviométricos (Silva Júnior, 2016) 
Tabela 22: Máxima diária e médias anuais (Silva Júnior, 2016).

\begin{tabular}{c|c|c}
\hline Posto & Máxima diária $(\mathbf{m m})$ & Média anual $(\mathbf{m m})$ \\
\hline C4-022 & 140 & 1090,8 \\
\hline C4-092 & 186,1 & 1451,4 \\
\hline C4-101 & 110,4 & 1498,7 \\
\hline D4-015 & 155,6 & 1410,6 \\
\hline D4-017 & 116,6 & 1439,5 \\
\hline D4-045 & 106,0 & 1318,7 \\
\hline D4-075 & 149,0 & 1546,1 \\
\hline D4-106 & 183,2 & 1588,0 \\
\hline D5-076 & 185,3 & 1458,8 \\
\hline C5-035 & 169,0 & 1491,7 \\
\hline D4-033 & 142,5 & 1425,7 \\
\hline D4-037 & 127,0 & 1356,9 \\
\hline D4-035 & 157,2 & 1370,0 \\
\hline
\end{tabular}

Tabela 23: Médias mensais (Silva Júnior, 2016).

\begin{tabular}{c|c|c|c|c|c|c|c|c|c|c|c|c}
\hline \multirow{2}{*}{ Posto } & \multicolumn{10}{|c}{ Média mensal (mm) } \\
\cline { 2 - 14 } & Jun & Jul & Ago & Set & Out & Nov & Dez & Jan & Fev & Mar & Abr & Mai \\
\hline C4-022 & 33,4 & 14,2 & 20,3 & 37,8 & 87,4 & 122,7 & 147,8 & 191,6 & 154,5 & 145,6 & 49,3 & 38,7 \\
\hline C4-092 & 35,4 & 24,8 & 28 & 62,4 & 129,3 & 162 & 251,3 & 259,7 & 192,5 & 173,1 & 78,2 & 57,2 \\
\hline C4-101 & 37,3 & 31,4 & 28,9 & 72,1 & 132,7 & 158,6 & 259,3 & 257,9 & 206,9 & 166 & 85,5 & 62,1 \\
\hline D4-015 & 46,6 & 26,3 & 26,8 & 63,2 & 125,4 & 151,8 & 243,9 & 241,6 & 199,4 & 162,1 & 69,5 & 60,7 \\
\hline D4-017 & 49,2 & 27 & 35,7 & 61 & 122,8 & 149,1 & 256,4 & 262,1 & 192,2 & 150,7 & 72,9 & 60,4 \\
\hline D4-045 & 44,9 & 21,4 & 18,7 & 41,7 & 122,4 & 141,1 & 218,7 & 242,2 & 205,1 & 166,6 & 53,5 & 42,5 \\
\hline D4-075 & 47,5 & 35,2 & 35,7 & 80,1 & 130,2 & 154,7 & 261,5 & 238 & 215,7 & 185,2 & 90,4 & 71,9 \\
\hline D4-106 & 50,7 & 29,1 & 30,7 & 79,5 & 127,7 & 163,6 & 251,3 & 291,6 & 220 & 179,5 & 92,7 & 71,7 \\
\hline D5-076 & 44,6 & 24,2 & 29,2 & 67,2 & 128,8 & 163 & 230,6 & 263,8 & 209,7 & 156,2 & 78,5 & 58,4 \\
\hline C5-035 & 40,4 & 23,7 & 22,1 & 61,2 & 122,3 & 171,2 & 252,8 & 254,9 & 218,4 & 179,6 & 68,2 & 56,6 \\
\hline D4-033 & 43 & 27,4 & 27,4 & 62,8 & 136,5 & 162 & 212,8 & 248,5 & 207,5 & 159,1 & 69,1 & 60,1 \\
\hline D4-037 & 40,1 & 25,6 & 23,7 & 56 & 120,9 & 157,6 & 219,1 & 239,4 & 205,9 & 156,7 & 65,4 & 56,4 \\
\hline D4-035 & 41,7 & 26,5 & 27,8 & 61,8 & 123,9 & 155,5 & 213,1 & 244,3 & 210,6 & 156,1 & 64,6 & 55 \\
\hline
\end{tabular}

\subsection{Trabalhos de Campo}

Os trabalhos de campo, foram realizados desde a etapa inicial do trabalho até a análise dos resultados. Alguns dos campos foram realizados junto ao coordenador municipal da defesa civil de São Carlos. As coordenadas dos pontos registrados durante toda a pesquisa e sua distribuição espacial, estão apresentadas na Tabela 24 e Apêndice B respectivamente. 
Tabela 24: Pontos levantados nas campanhas de campo.

\begin{tabular}{|c|c|c|}
\hline \multirow{2}{*}{ Ponto } & \multicolumn{2}{|c|}{ Córrego Alegre 23S } \\
\hline & $\mathbf{X}$ & $\mathbf{Y}$ \\
\hline 1 & 200700 & 7558428 \\
\hline 2 & 199563 & 7557945 \\
\hline 3 & 200678 & 7558891 \\
\hline 4 & 200703 & 7558896 \\
\hline 5 & 201622 & 7561522 \\
\hline 6 & 201529 & 7561868 \\
\hline 7 & 201183 & 7562271 \\
\hline 8 & 201019 & 7562419 \\
\hline 9 & 199482 & 7562334 \\
\hline 10 & 199384 & 7562440 \\
\hline 11 & 199276 & 7562212 \\
\hline 12 & 199186 & 7561850 \\
\hline 13 & 199450 & 7562504 \\
\hline 14 & 199932 & 7563070 \\
\hline 15 & 199932 & 7563069 \\
\hline 16 & 200194 & 7563370 \\
\hline 17 & 200234 & 7563400 \\
\hline 18 & 200591 & 7564101 \\
\hline 19 & 200567 & 7564149 \\
\hline 20 & 200607 & 7564289 \\
\hline 21 & 200733 & 7564389 \\
\hline 22 & 200843 & 7564482 \\
\hline 23 & 202974 & 7565918 \\
\hline 24 & 202976 & 7565909 \\
\hline 25 & 202424 & 7565907 \\
\hline 26 & 201478 & 7561448 \\
\hline 27 & 201535 & 7561025 \\
\hline 28 & 205557 & 7560260 \\
\hline 29 & 200840 & 7558768 \\
\hline 30 & 200903 & 7559046 \\
\hline 31 & 200145 & 7562553 \\
\hline 32 & 200283 & 7562536 \\
\hline 33 & 199548 & 7562621 \\
\hline 34 & 199247 & 7562405 \\
\hline 35 & 198920 & 7560842 \\
\hline 36 & 198833 & 7560430 \\
\hline 37 & 198807 & 7560561 \\
\hline 38 & 198188 & 7560783 \\
\hline 39 & 197541 & 7560811 \\
\hline 40 & 197808 & 7560766 \\
\hline 41 & 195776 & 7560598 \\
\hline
\end{tabular}


Tabela 24 continuação: Pontos levantados nas campanhas de campo.

\begin{tabular}{c|c|c}
\hline \multirow{2}{*}{ Ponto } & \multicolumn{2}{|c}{ Córrego Alegre 23S } \\
\cline { 2 - 3 } & $\mathbf{X}$ & $\mathbf{Y}$ \\
\hline 42 & 194840 & 7560214 \\
\hline 43 & 196893 & 7567982 \\
\hline 44 & 201536 & 7562091 \\
\hline
\end{tabular}

Todos os pontos registrados no campo, mostraram que a localização dos eventos levantados nos jornais, defesa civil e imagens de satélite estão condizentes, além disso, verificou-se que os mapas temáticos e de suscetibilidades gerados, estão de acordo com as características do meio físico. As Figuras 18 a 21 apresentam alguns dos pontos visitados.

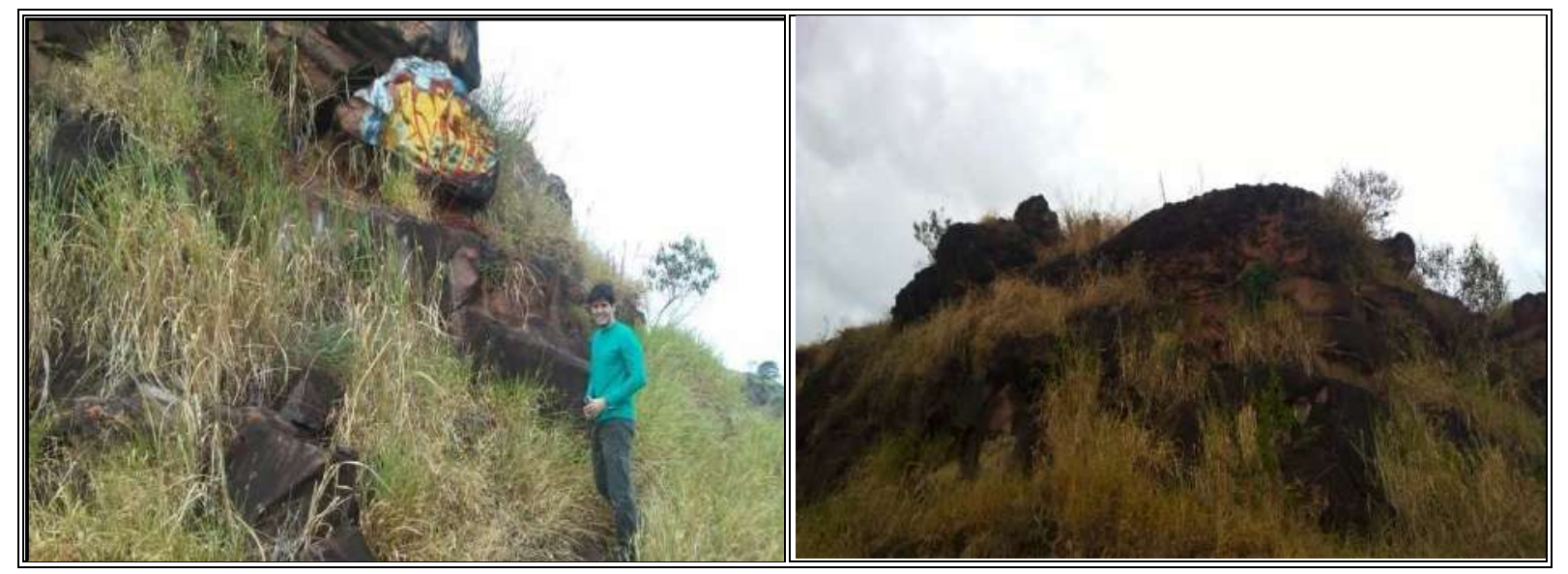

Figura 18: Talude na avenida integração.
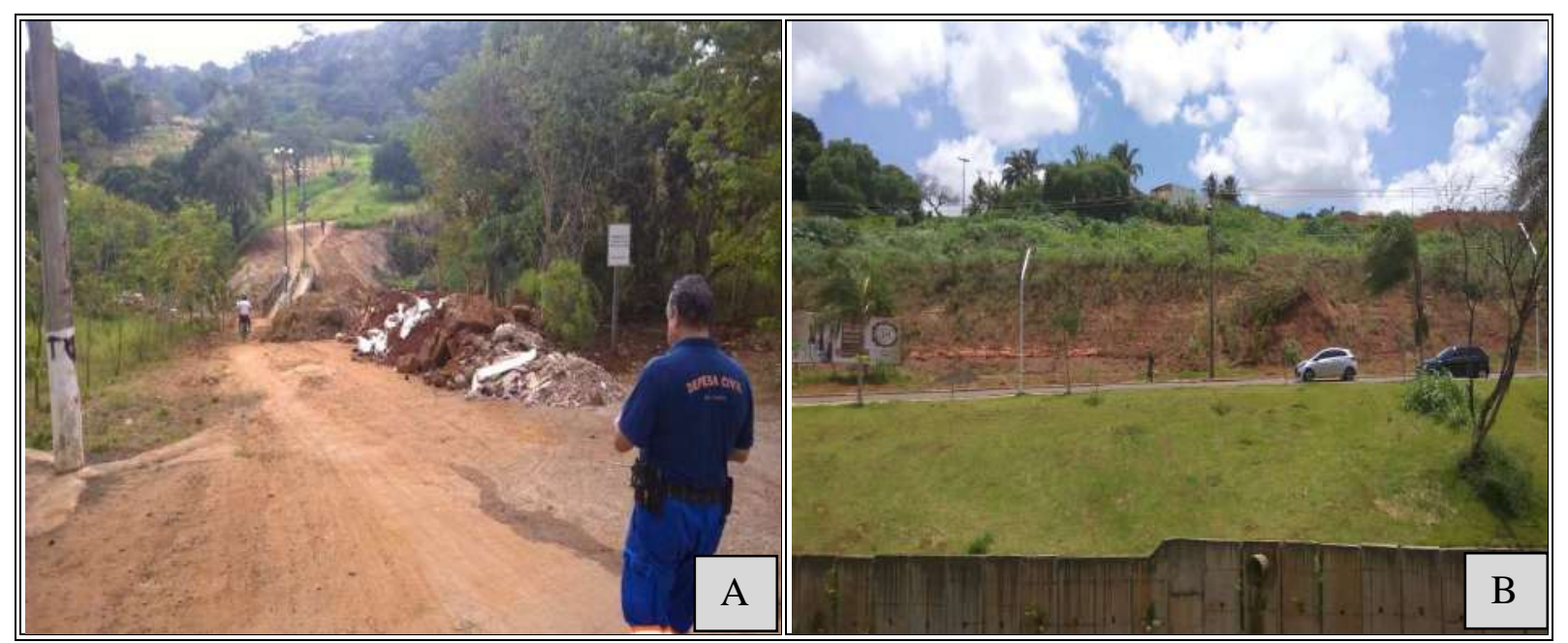

Figura 19: (A) Local na cidade de Aracy, (B) talude na avenida Comendador Alfredo Maffei 


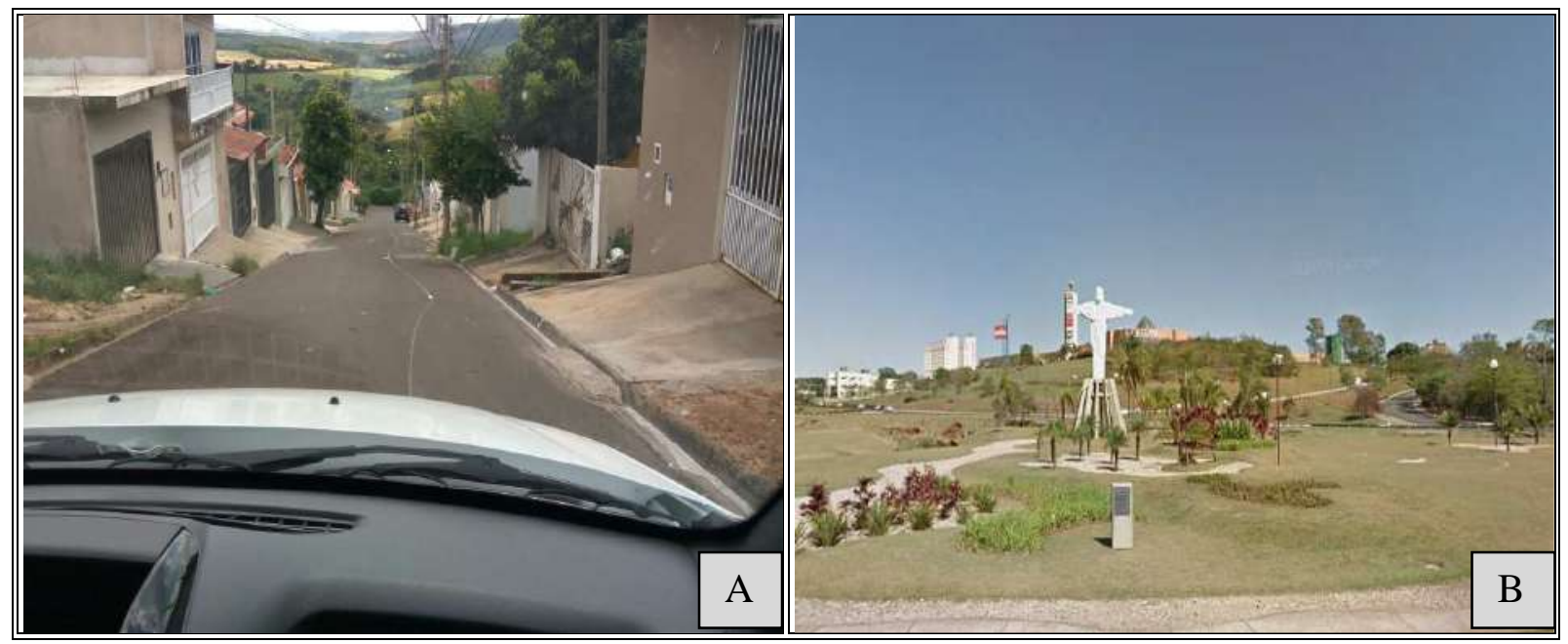

Figura 20: (A) Rua no bairro Jardim das Torres, (B) rotatória do cristo

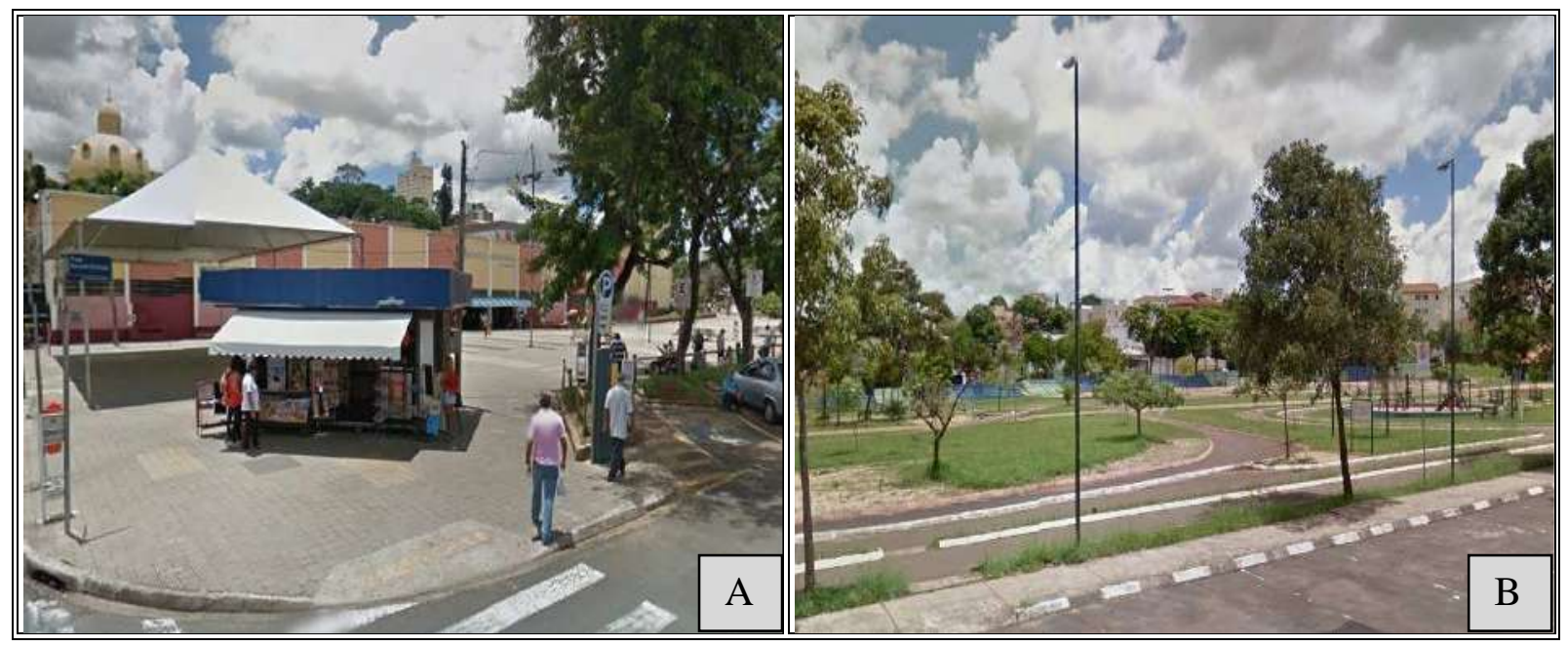

Figura 21: (A) Região do mercado municipal, (B) região do kartódromo.

\subsection{Eventos Geológicos e Hidrológicos Cadastrados}

Como parte fundamental do trabalho, foi realizada uma extensa pesquisa nos registros de ocorrências diárias da defesa civil entre os anos de 2005 a 2012, nos jornais do município entre os anos de 1965 a 2016, e nas imagens antigas de satélite do Google Earth Pro ${ }^{\circledR}$. Os dados referentes a estes eventos são apresentados no Apêndice A, e a distribuição espacial, no mapa de documentação (Apêndice B). Ao todo foram registrados 482 eventos no período pesquisado. 
Algumas das publicações de jornais, referentes aos eventos perigosos podem ser observadas nas Figuras 22 e 23.
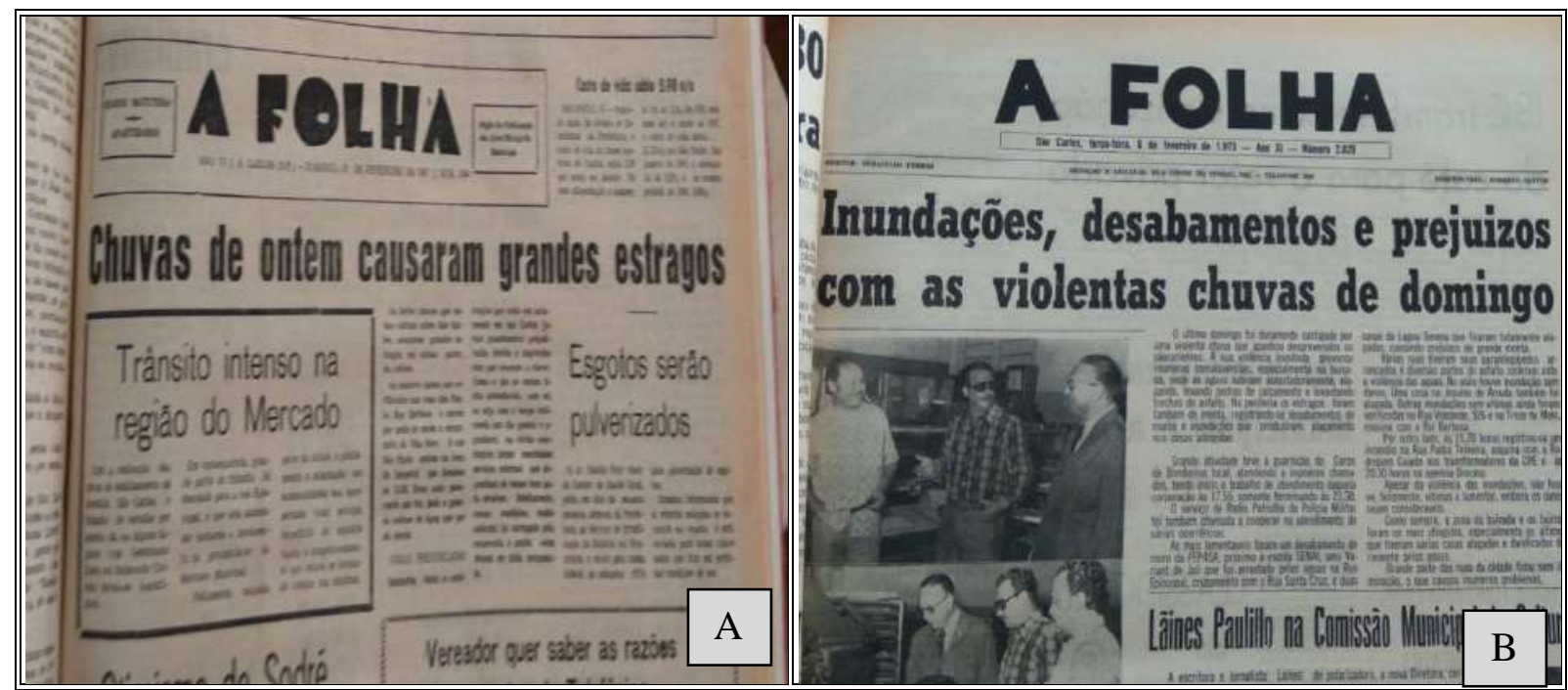

Figura 22: (A) reportagem do dia 18 de fevereiro de 1967, (B) reportagem do dia 6 de fevereiro de 1973.

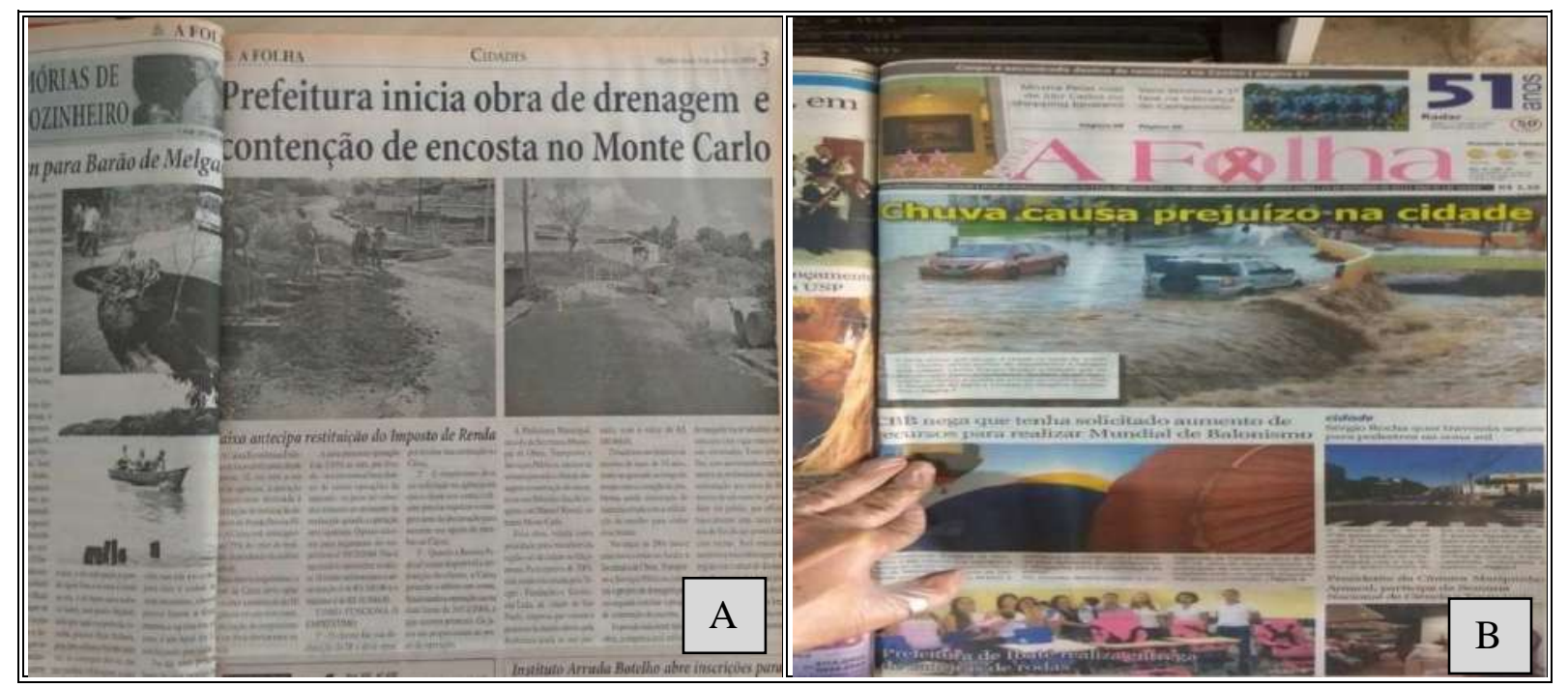

Figura 23: (A) reportagem do dia 3 de março de 2004, (B) reportagem do dia 23 de outubro de 2013.

Para os eventos cadastrados a partir do mosaico, adotou-se a data de captura da imagem pelo satélite, tornando este método impreciso, visto que um evento registrado na imagem pode ter ocorrido muito tempo antes da data de captura pelo satélite. 


\subsection{Mapas Temáticos}

\subsubsection{Compartimentos geológico-geotécnicos}

Foi utilizado a compartimentação geológica-geotécnica (Figura 24) feita por Bartolomeu (2012). Na Tabela 25 pode-se observar as áreas e porcentagem em relação ao total, que cada compartimento ocupa na região.

O compartimento Itaqueri composto por arenitos, com algumas porções mais silto argilosas, ocupa quase que totalmente a região centro-norte da região de estudos, representando aproximadamente $70,0 \%$ do total, sendo que a área urbana está quase que totalmente inserida nesta formação.

A região sul é basicamente composta pelo compartimento Botucatu, composta por arenitos quartzosos com teor de finos incipientes e representa 26,9\% da área. Uma das regiões mais pobres do município (Cidade Aracy) está inserida nesta formação.

O compartimento Serra Geral é composta por basaltos afaníticos e por solos argilosos, representa $2,7 \%$ da área, e no centro da cidade está associado aos vales e leitos de rios.

O compartimento coluvionar é constituídos por material de textura arenosa, imatura, e saturada e o aluvionar (argilo-arenoso) é composto por finos e grãos de quartzo referentes a Formação Botucatu e grãos de quartzo relacionados a Formação Itaqueri, juntos os dois representam menos de $2,0 \%$ da região estudada.

A análise deste mapa é fundamental, visto que eventos como movimentos de encosta, processos erosivos e colapso de solos estão diretamente ligados ao tipo de solo e rocha do local de ocorrência.

Tabela 25: Compartimentos geotécnicos e suas respectivas áreas e porcentagens de ocupação.

\begin{tabular}{c|c|c}
\hline \multirow{2}{*}{ Compartimentos } & \multicolumn{2}{|c}{ Área } \\
\cline { 2 - 3 } & $\mathbf{( K m}^{\mathbf{2}} \mathbf{~}$ & $\mathbf{\%}$ \\
\hline Coluvionar & 0,84 & 0,6 \\
\hline Aluvionar & 1,05 & 0,7 \\
\hline Compartimento Itaqueri & 102,98 & 69,1 \\
\hline Compartimento Serra Geral & 4,01 & 2,7 \\
\hline Compartimento Botucatu & 40,09 & 26,9 \\
\hline Total & 148,97 & 100,0 \\
\hline
\end{tabular}




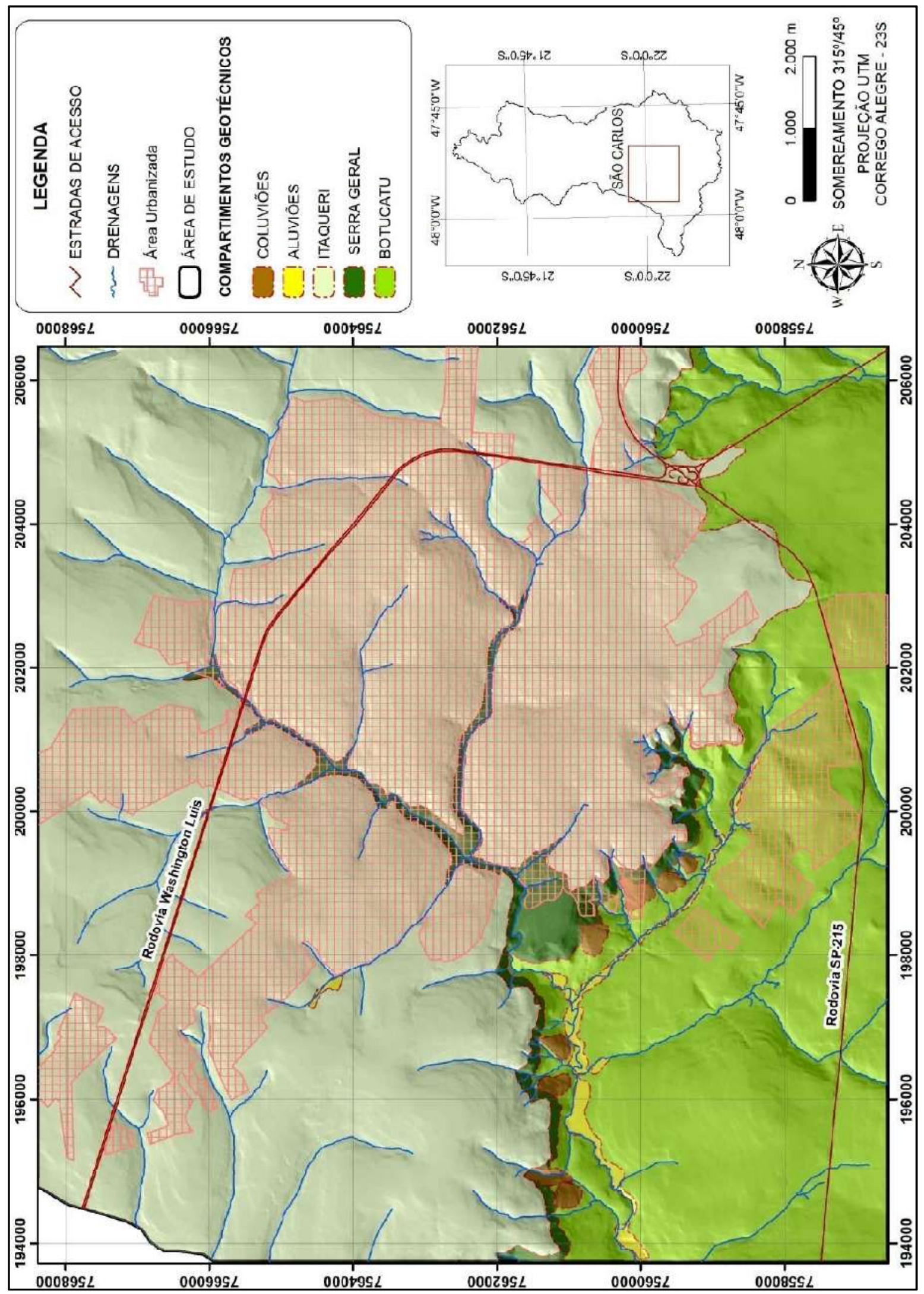

Figura 24: Mapa de compartimentos geológico-geotécnicos do município de São Carlos - SP. 


\subsubsection{Uso e ocupação}

O mapa de uso e ocupação (Figura 25) foi gerado a partir da análise do mosaico de imagens de satélite. A área de estudo foi dividida em 6 classes de uso e ocupação (agricultura; área de expansão; fragmento de mata; indústria; reflorestamento e área urbana). As áreas ocupadas por cada classe assim como a porcentagem são apresentadas na Tabela 26.

Tabela 26: Uso e ocupação e suas respectivas áreas e porcentagens de ocupação.

\begin{tabular}{|c|c|c|}
\hline \multirow{2}{*}{ Uso e Ocupação } & \multicolumn{2}{|c|}{ Área } \\
\hline & $\left(\mathbf{K m}^{2}\right)$ & $\%$ \\
\hline Agricultura & 38,67 & 26,0 \\
\hline Área de Expansão & 24,57 & 16,5 \\
\hline Área Urbana & 54,30 & 36,5 \\
\hline Fragmento de mata & 17,59 & 11,8 \\
\hline Indústria & 1,85 & 1,2 \\
\hline Reflorestamento & 11,99 & 8,0 \\
\hline Total & 148,97 & 100,0 \\
\hline
\end{tabular}

Como pode-se observar a área urbana ocupa a maior região na área de estudos, sendo responsável por $54,30 \mathrm{Km}^{2}$ (36,5\%), sendo que em seu entorno há uma área de expansão que abrange $24,57 \mathrm{Km}^{2}(16,5 \%)$, juntas, estas duas classes representam mais de $50 \%$ da área estudada.

A agricultura ocupa quase que toda região a oeste da área urbanizada e uma parte ao norte também, sendo responsável por $38,67 \mathrm{Km}^{2}(26,0 \%)$ do total. Os principais produtos são a cana-de-açúcar e a laranja.

Há duas grandes áreas de reflorestamento (eucalipto) uma a sudeste outra a nordeste, sendo que as duas juntas ocupam $11,99 \mathrm{Km}^{2}$ (8,0\%). As indústrias ocupam 1,85 $\mathrm{Km}^{2}(1,2 \%)$, e situam-se uma na região sul e outras duas na região sudeste.

O restante é representado por fragmentos de mata nativa (cerrado), que abrangem $17,59 \mathrm{Km}^{2}(11,8 \%)$, na maioria das vezes esses fragmentos estão associados as redes de drenagem e fora da área urbanizada. 


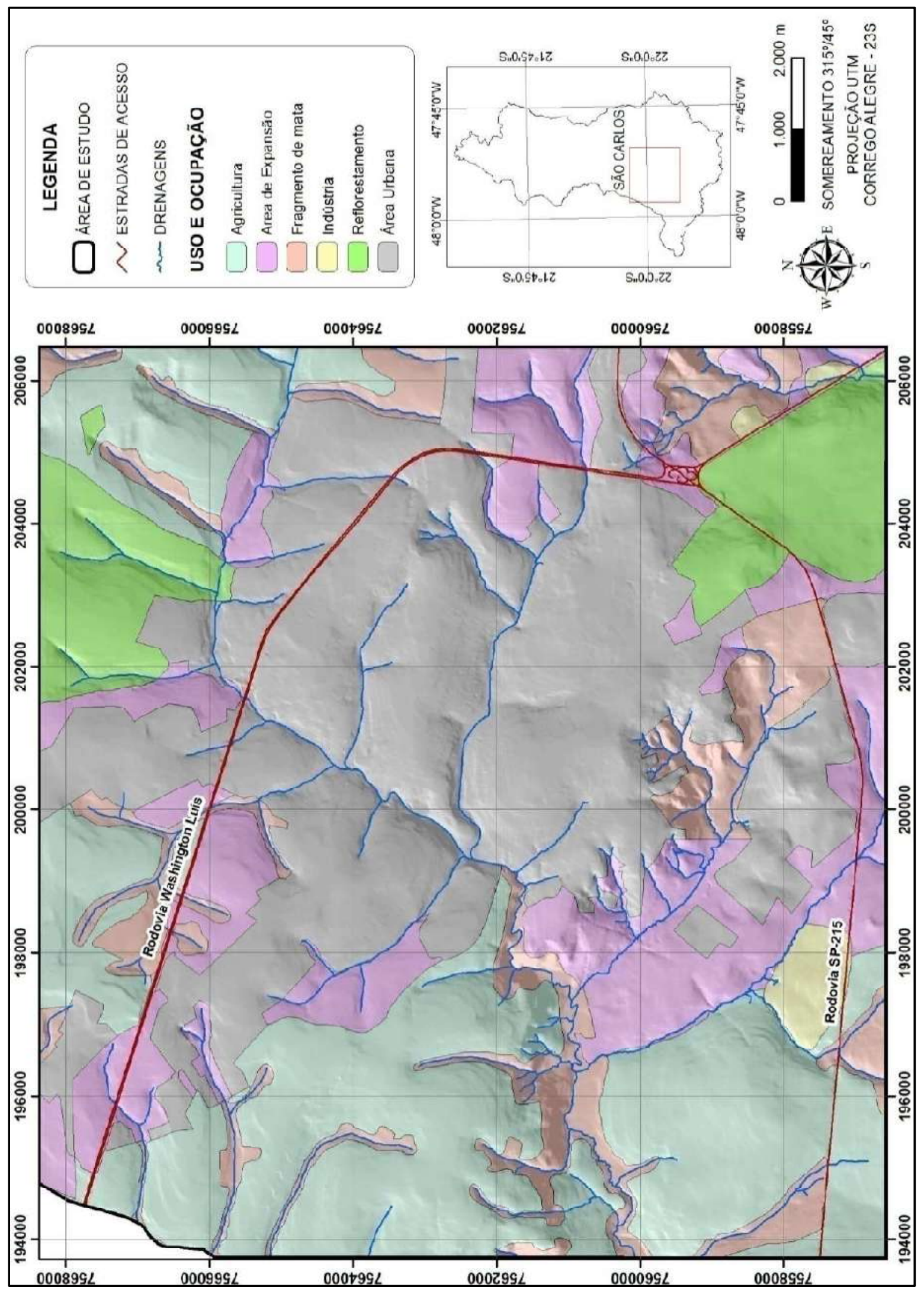

Figura 25: Mapa de uso e ocupação do município de São Carlos - SP. 


\subsubsection{Declividades (\%)}

A Tabela 27 sintetiza a distribuição das classes de declividades, enquanto que a Figura 26 ilustra o produto cartográfico. Este mapa, é de grande importância, e possui uma relação direta com todos os eventos mapeados nesta pesquisa.

Declividades maiores aumentam as chances de ocorrência de movimentos de encostas, enquanto que processos erosivos ocorrem normalmente em declividades intermediarias, já colapso de solos, inundações e alagamentos ocorrem usualmente em declividades baixas.

Tabela 27: Classes de declividades e suas respectivas áreas e porcentagens de ocupação.

\begin{tabular}{c|c|c}
\hline \multirow{2}{*}{ Declividades $(\boldsymbol{\%})$} & \multicolumn{2}{|c}{ Área } \\
\cline { 2 - 3 } & $\left(\mathbf{K m}^{\mathbf{2}}\right)$ & $\mathbf{\%}$ \\
\hline $0-5$ & 68,69 & 46,1 \\
\hline $5-10$ & 52,02 & 34,9 \\
\hline $10-18$ & 21,71 & 14,6 \\
\hline $18-33$ & 5,26 & 3,5 \\
\hline$>33$ & 1,30 & 0,9 \\
\hline Total & 148,97 & 100,00 \\
\hline
\end{tabular}

Observando a Tabela 27 e Figura 26, nota-se que a classe predominante é a de 0 a $5 \%$ ocupando uma área de $68,69 \mathrm{Km}^{2}(46,1 \%)$, as classes de relevo pouco íngreme, de 0 a $10 \%$ abrangem uma área de $120,71 \mathrm{Km}^{2}(81,0 \%)$, evidenciando que a área de estudo possui um relevo predominantemente suave.

Declividades acima de $18 \%$ ocupam uma área de $6,56 \mathrm{Km}^{2}(4,4 \%)$ e ocorrem em sua maioria na região sul e sudoeste, associados normalmente no contato do compartimento Serra Geral e Botucatu (Figura 24). 


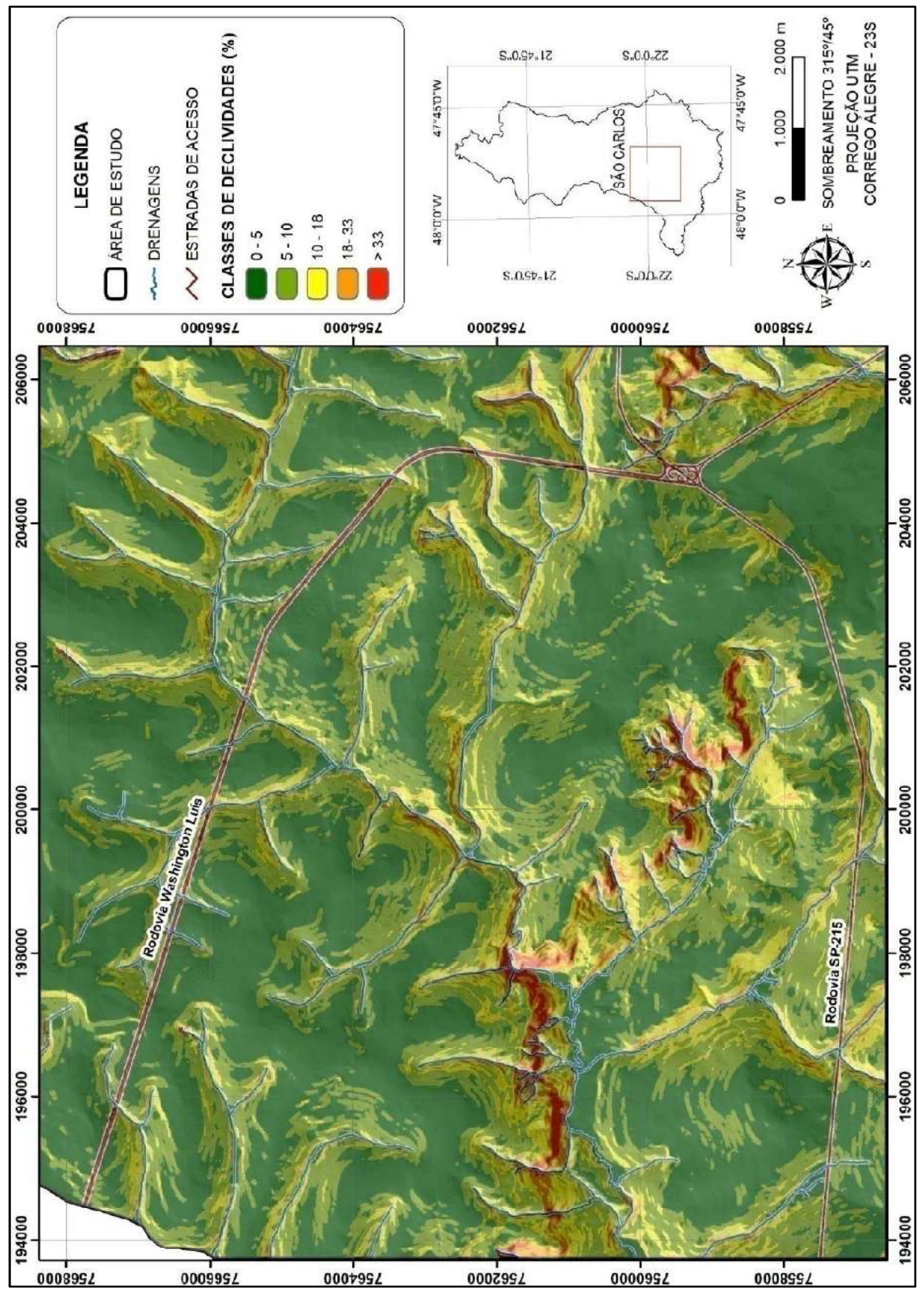

Figura 26: Mapa de declividades do município de São Carlos - SP. 


\subsubsection{Forma das encostas}

O mapa foi dividido em três tipos de formas de encostas, coletora, dispersora e plana. A Tabela 28 apresenta a distribuição em área das formas das encostas do terreno e a Figura 27 ilustra o mapa para a área de estudos.

Tabela 28: Formas de encostas e suas respectivas áreas e porcentagens de ocupação.

\begin{tabular}{c|c|c}
\hline \multirow{2}{*}{ Forma de Encostas } & \multicolumn{2}{|c}{ Área } \\
\cline { 2 - 3 } & $\mathbf{( \mathbf { K m } ^ { \mathbf { 2 } } )}$ & $\mathbf{\%}$ \\
\hline Coletora & 55,58 & 37,4 \\
\hline Plana & 18,81 & 12,6 \\
\hline Dispersora & 74,58 & 50,0 \\
\hline Total & 148,97 & 100,00 \\
\hline
\end{tabular}

Encostas do tipo coletora ocupam uma área de $55,58 \mathrm{Km}^{2}$ (37,4\%). Estas encostas são responsáveis por concentrarem o fluxo de água, desta forma, são mais favoráveis ao surgimento de processos erosivos e movimentos de encostas, e estão associadas a fundo de vales e drenagens

Encostas dispersoras são caracterizadas por desacelerarem e dispersarem o fluxo d'água, sendo menos favoráveis ao surgimento de processos erosivos e movimentos de encosta e mais favoráveis a deposição de sedimentos. Abrangem uma área de 74,58 $\mathrm{Km}^{2}$ $(50,0 \%)$. 


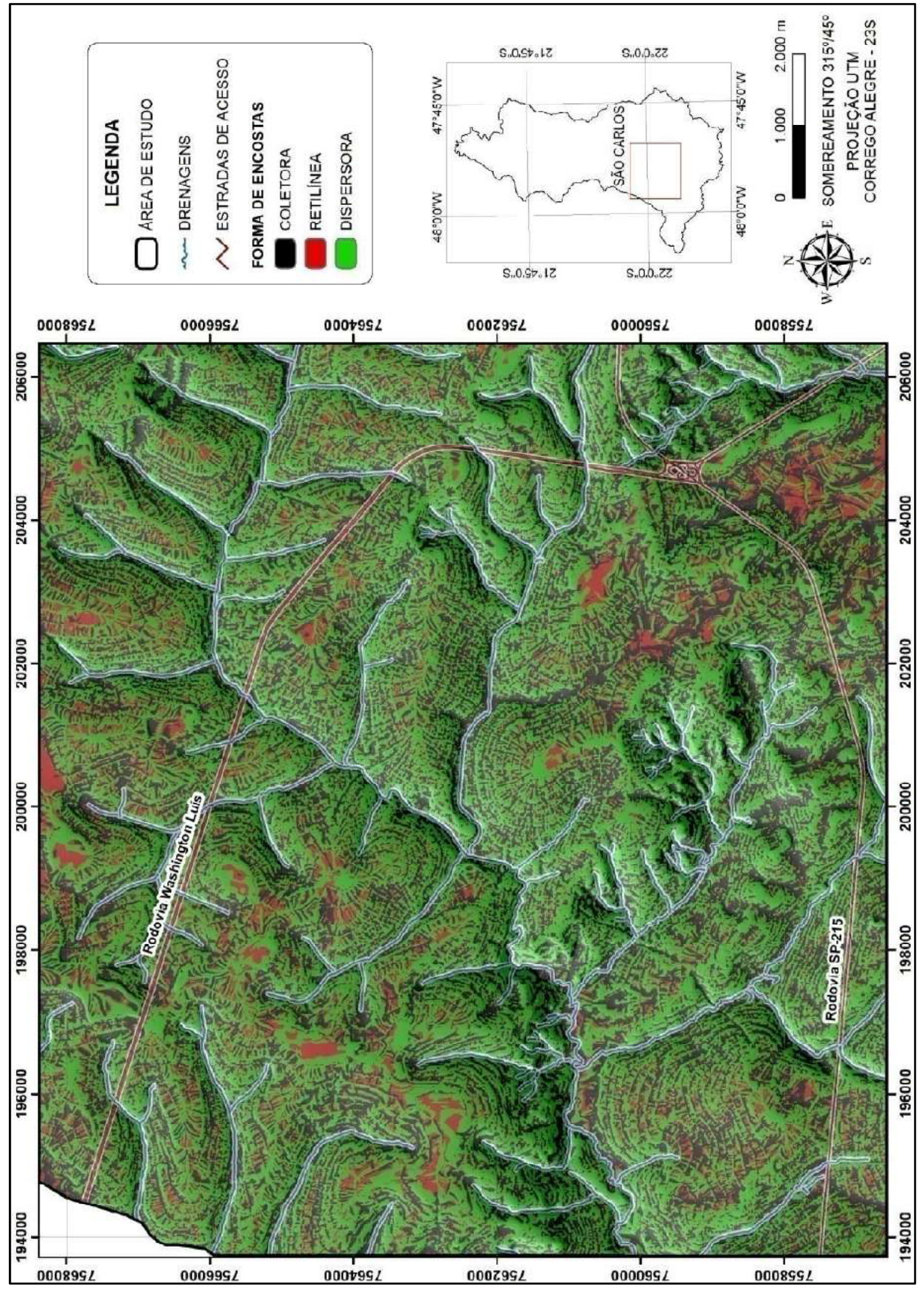

Figura 27: Mapa de formas de encostas do município de São Carlos - SP. 


\subsubsection{Documentação}

O mapa de documentação (Apêndice B) é composto por 482 eventos perigosos de natureza geológica e hidrológica cadastrados entre os anos 1965 a 2016, pelos pontos levantados em campo e pelos pontos que foram amostrados e ensaiados por Aguiar (1989) e Bartolomeu (2012). Estes pontos são apresentados em conjunto com a base cartográfica digital. É importante ressaltar que um ponto no mapa pode representar mais de um evento, porém ocorridos em datas distintas.

\subsection{Mapas de Concentração de Eventos}

Primeiramente, foi feita uma análise da distribuição de cada evento na área de estudos. Analisou-se também a distribuição temporal de cada evento em relação aos anos, períodos e meses. Os eventos analisados foram as enchentes/inundações, alagamentos, movimento de encosta, processos erosivos e colapsos de solo.

Ao todo foram catalogados 482 eventos perigosos entre os anos de 1965 a 2016, vale ressaltar que vários eventos podem ocorrer no mesmo dia, em locais diferentes do município. O principal agente natural deflagrador, principalmente para os movimentos de encosta, processos erosivos, enchentes/inundações e alagamentos são as chuvas concentradas. Os meses mais críticos são Fevereiro, Janeiro e Dezembro, justamente os meses mais chuvosos (Figura 28).

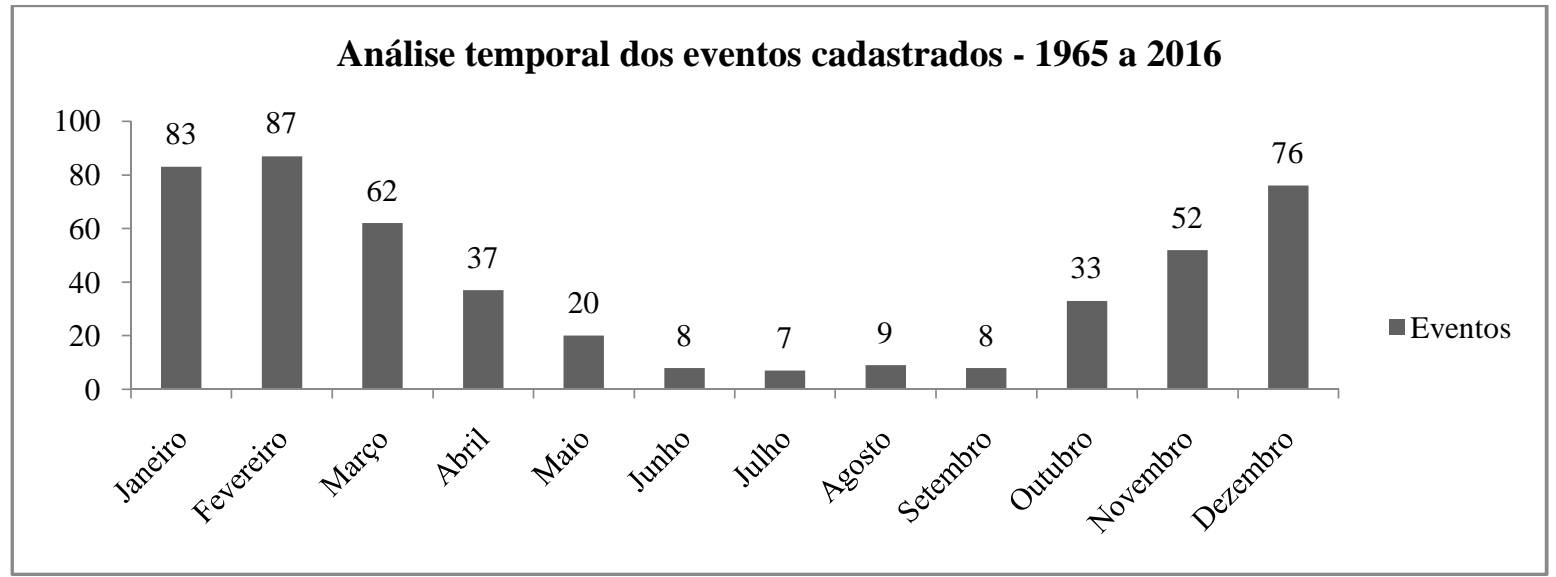

Figura 28: Análise mensal dos eventos registrados. 
Como pode se observar na Figura 29, mais de 50\% dos eventos registrados ocorreram a partir do ano de 2000, isto ocorre basicamente por dois fatores, antes dos anos 70 a cidade tinha uma população pequena e consideravelmente rural, a partir dos anos 70 a urbanização começa a se intensificar, muitas vezes, sem o devido controle, contribuindo para a ocorrência desses eventos. Outro fator é que quanto mais perto do presente, maior a riqueza de detalhes e registros dos eventos, devido ao uso cada vez mais intenso de tecnologia para registrar-los.

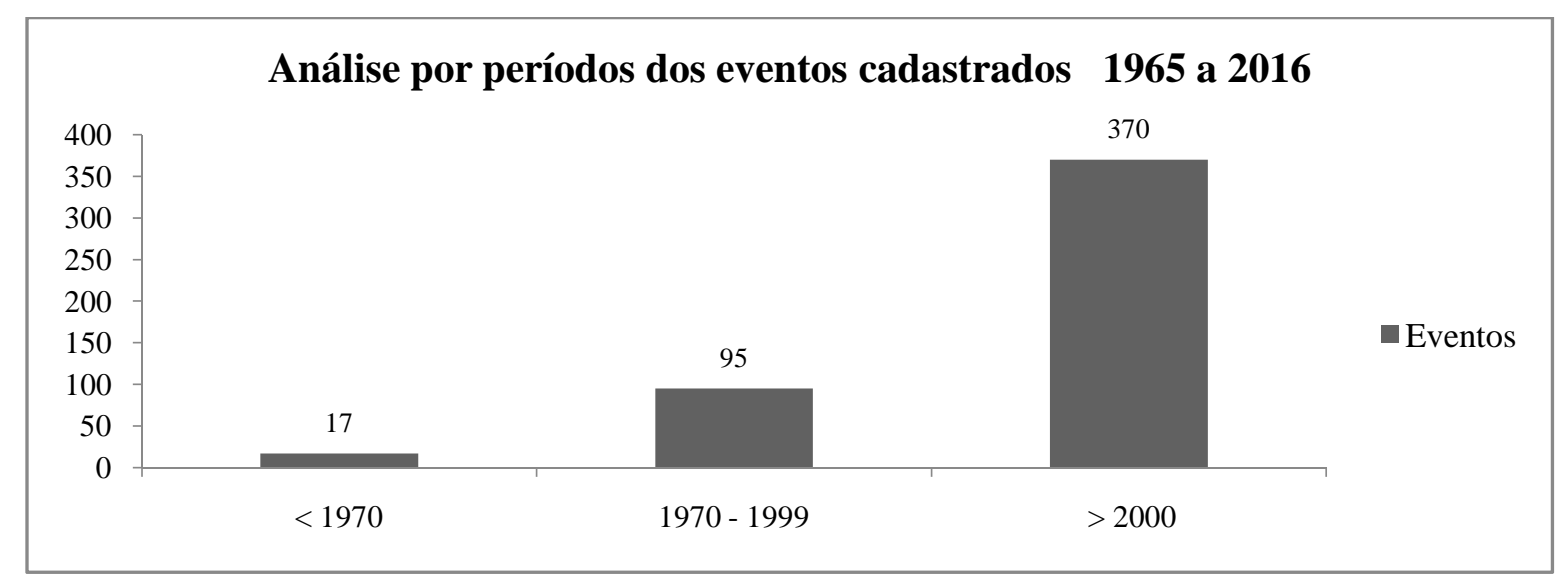

Figura 29: Análise por períodos dos eventos registrados.

O evento que possui mais registros na cidade são as enchentes/inundações, mais que o dobro do $2^{\circ}$ mais freqüente (alagamentos), seguido pelos processos erosivos, colapso de solos e movimentos de encosta (Figura 30). Este resultado já era esperado, o mapa de declividades (Figura 26), apresenta um relevo suave, com poucas regiões na área que possuem declividades acima de $18 \%$.

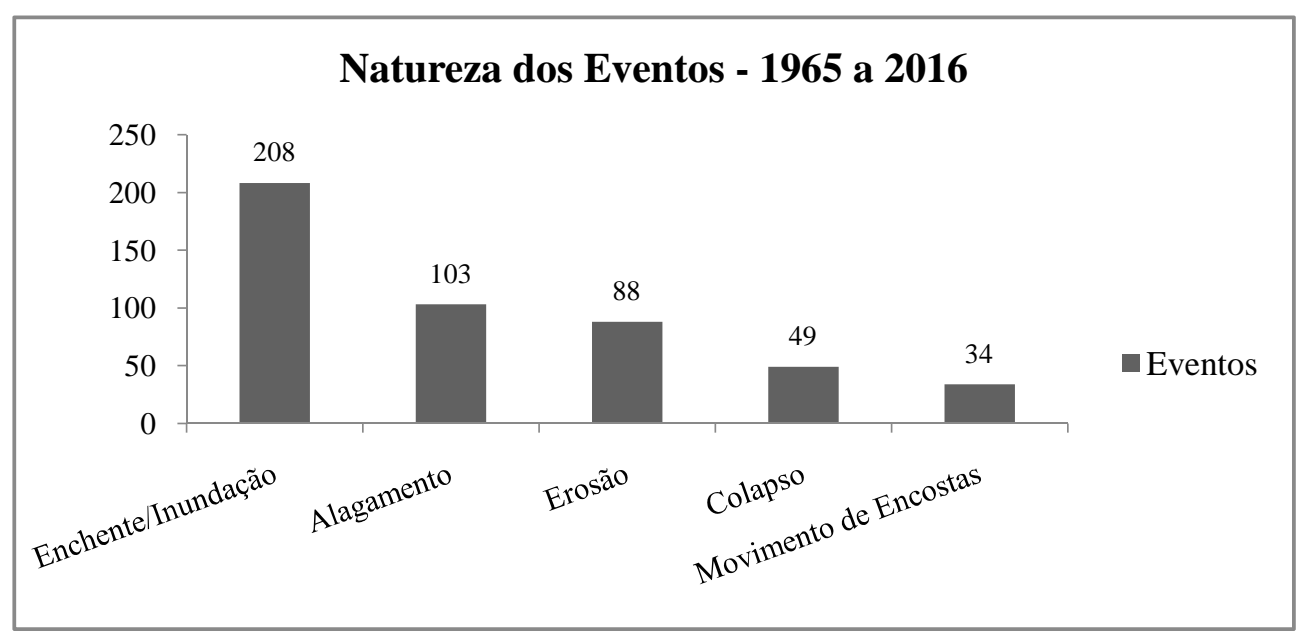

Figura 30: Natureza dos eventos na região e quantidades registradas. 
Analisando a distribuição mensal de cada evento separadamente (Figura 31), fica claro que os meses de verão (chuvosos) realmente são os mais críticos, evidenciando a contribuição das chuvas como agente deflagrador.

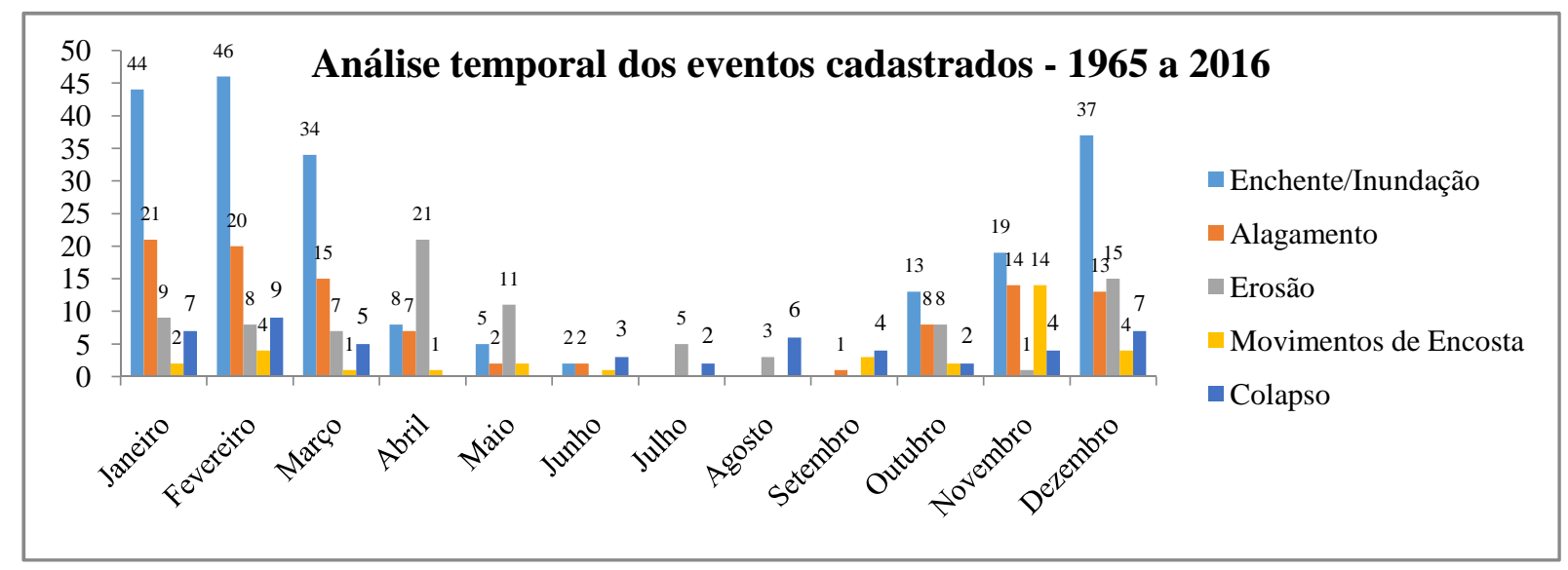

Figura 31: Análise mensal dos eventos cadastrados feita separadamente.

Em relação as bacias hidrográficas, a que se mostra mais crítica é a do Gregório, tendo mais que o dobro de eventos registrados que a do Médio Monjolinho, a segunda mais critica. As Figuras 32 e 33 apresentam a freqüência de todos os eventos cadastrados e dos tipos de eventos cadastrados respectivamente, em ralação as bacias hidrográficas.

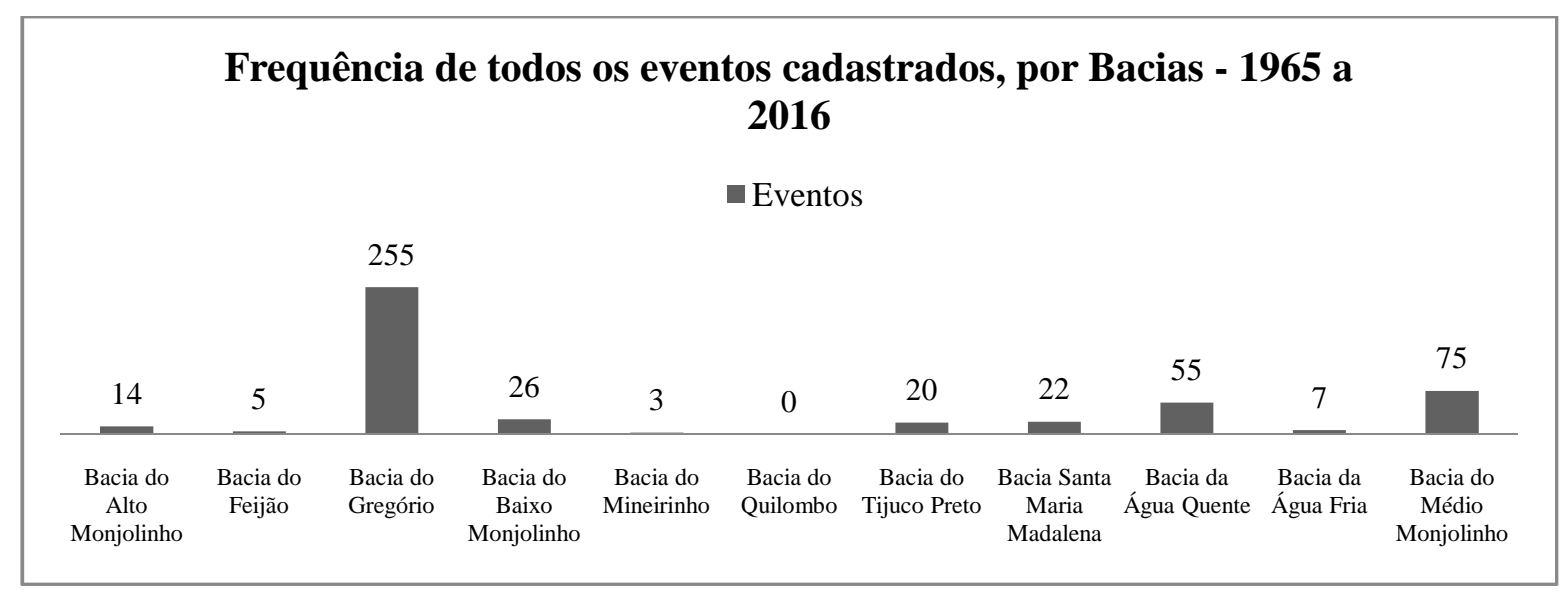

Figura 32: Freqüência de todos os eventos cadastrados. 


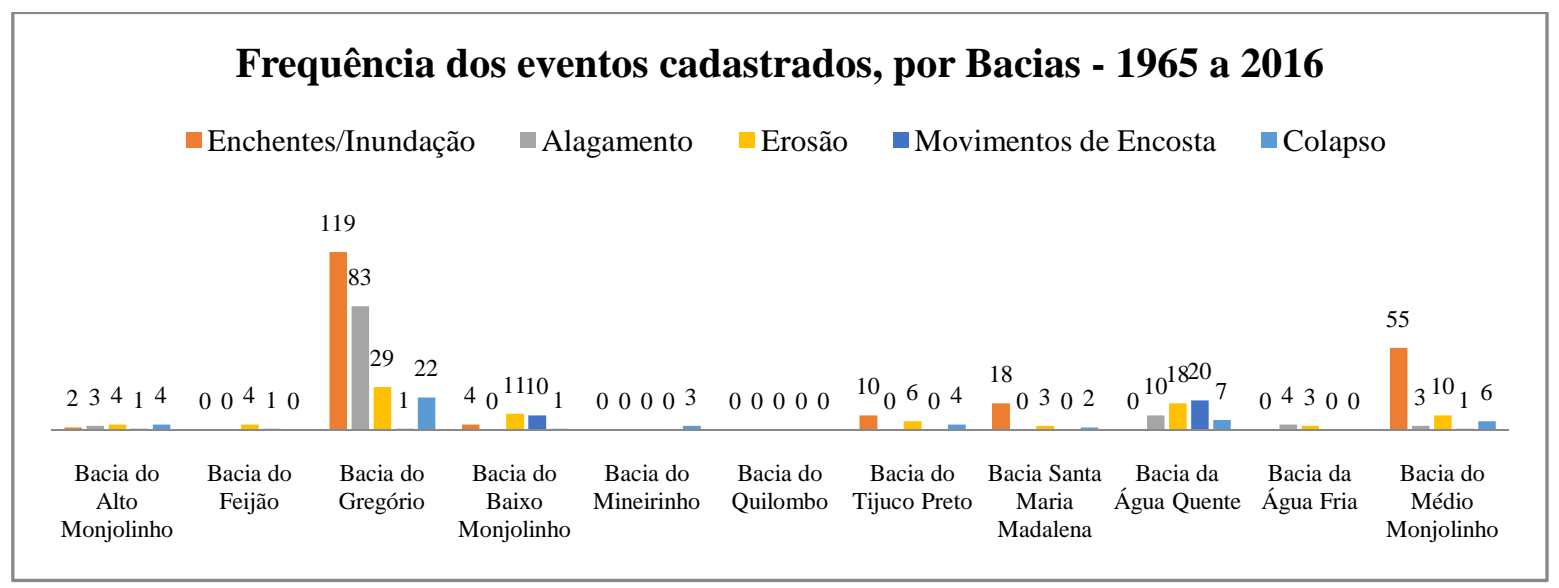

Figura 33: Freqüência dos tipos de eventos cadastrados.

Analisando o número de eventos em relação a área de cada bacia (Tabela 29), para observar a sua influência na ocorrência destes eventos, obteve-se um índice de concentração (IC). Nesta análise ocorre uma inversão, onde a bacia do Médio Monjolinho torna-se mais crítica que a bacia do Gregório, isto ocorre em decorrência da área da bacia do Médio Monjolinho ser sete vezes menor.

Tabela 29: Índice de concentração de eventos por $\mathrm{Km}^{2}$ de cada bacia.

\begin{tabular}{|c|c|c|}
\hline Bacias & Área $\left(\mathrm{Km}^{2}\right)$ & Eventos/Km ${ }^{2}$ \\
\hline Bacia do Alto Monjolinho & 26,38 & 0,53 \\
\hline Bacia do Feijão & 11,93 & 0,42 \\
\hline Bacia do Gregório & 18,34 & 13,90 \\
\hline Bacia do Baixo Monjolinho & 41,10 & 0,63 \\
\hline Bacia do Mineirinho & 5,83 & 0,51 \\
\hline Bacia do Quilombo & 2,81 & 0,00 \\
\hline Bacia do Tijuco Preto & 3,53 & 5,67 \\
\hline Bacia Santa Maria Madalena & 11,29 & 1,95 \\
\hline Bacia da Água Quente & 12,92 & 4,26 \\
\hline Bacia da Água Fria & 12,31 & 0,57 \\
\hline Bacia do Médio Monjolinho & 2,54 & 29,53 \\
\hline
\end{tabular}

Em seguida realizou-se uma análise de quantificação de cada evento por cada classe, de cada condicionante (probabilidades iniciais), a fim de se obter as classes mais criticas para cada evento. Esta é uma análise inicial, onde cada condicionante foi verificado separadamente. Ao fim de cada análise, foi gerado um mapa de concentração de eventos. 


\subsubsection{Movimentos de encosta}

Foi analisado a quantidade de movimentos de encosta, por cada classe dos seguintes condicionantes: uso e ocupação; compartimentos geotécnicos; formas de encostas e declividades. As informações obtidas no inventário, descrevem a maioria dos movimentos como escorregamento, com exceção de alguns em que houve também a queda de blocos.

A Tabela 30 apresenta os índices para cada classe de uso e ocupação. Como pode-se observar, 73,5\% dos movimentos de encostas ocorrem em fragmentos de mata, principalmente na serra de Aracy, sendo a classe com o maior índice de concentração também. Este fato contraria o senso comum de que áreas cobertas por vegetação são menos propicias a movimentos de encosta, porém nestes pontos de ocorrências, ocorrem as maiores declividades da área. É importante observar que 17,7\% destes eventos ocorreram na área de expansão, ou seja, regiões que podem vir a ser ocupadas no futuro, necessitando um maior cuidado no manejo, quando isto vier a ocorrer.

Tabela 30: Índice de concentração de movimentos de encosta para as classes de uso e ocupação.

\begin{tabular}{c|c|c|c|c|c}
\hline \multirow{2}{*}{ Uso e ocupação } & \multicolumn{2}{|c|}{ Área } & \multicolumn{2}{c|}{ Movimentos de Encosta } & $\begin{array}{c}\text { Índice de concentração } \\
\left(\mathbf{e v e n t o s}^{\mathbf{2}} \mathbf{K m}^{\mathbf{2}} \mathbf{)}\right.\end{array}$ \\
\cline { 2 - 6 } & $\left(\mathbf{K m}^{\mathbf{2}}\right)$ & $\mathbf{\%}$ & $\mathbf{N}^{\mathbf{0}}$ & $\mathbf{\%}$ & 0,00 \\
\hline Agricultura & 38,67 & 26,0 & 0 & 17,7 & 0,24 \\
\hline Área de expansão & 24,57 & 16,4 & 6 & 8,8 & 0,06 \\
\hline Área Urbana & 54,30 & 36,5 & 3 & 73,5 & 1,42 \\
\hline Fragmento de Mata & 17,59 & 11,8 & 25 & 0,0 & 0,00 \\
\hline Industria & 1,85 & 1,2 & 0 & 0,0 & 0,00 \\
\hline Reflorestamento & 11,99 & 8,1 & 0 &
\end{tabular}

Em relação aos compartimentos geólogico-geotécnicos, (Tabela 31) o mais crítico, quanto ao número de eventos, é o Botucatu, seguido pelo Serra Geral. As maiores declividades da região se encontram na serra de Aracy, onde ocorre o contato do destes dois compartimentos, justificando a maior freqüência de movimentos. No entanto, em relação ao índice de concentração ocorre uma inversão, onde o mais critico passa a ser o Serra Geral, seguido pelo Coluvionar, isto ocorre devido a grande diferença de dimensão dos compartimentos Serra Geral e Coluvionar em relação ao Botucatu.

Tabela 31: Índice de concentração de movimentos de encosta para os compartimentos geotécnicos.

\begin{tabular}{|c|c|c|c|c|c|}
\hline \multirow{2}{*}{$\begin{array}{c}\text { Compartimentos } \\
\text { geológico-geotécnicos }\end{array}$} & \multicolumn{2}{|c|}{ Área } & \multicolumn{2}{|c|}{ Movimentos de Encosta } & \multirow{2}{*}{$\begin{array}{c}\text { Índice de concentração } \\
\left(\text { eventos } / \mathbf{K m}^{2}\right)\end{array}$} \\
\hline & $\left(\mathrm{Km}^{2}\right)$ & $\%$ & $\mathbf{N}^{\circ}$ & $\%$ & \\
\hline Coluvionar & 0,84 & 0,6 & 1 & 2,9 & 1,19 \\
\hline Aluvionar & 1,05 & 0,7 & 0 & 0,0 & 0,00 \\
\hline Itaqueri & 102,98 & 69,1 & 6 & 17,7 & 0,06 \\
\hline Serra Geral & 4,01 & 2,7 & 8 & 23,5 & 2,00 \\
\hline Botucatu & 40,09 & 26,9 & 19 & 55,9 & 0,47 \\
\hline
\end{tabular}


Quanto as formas de encostas, a mais crítica é a coletora, tanto para a quantidade de eventos, quanto para o índice de concentração (Tabela 32). Este resultado está de acordo com o esperado, pois encostas coletoras concentram o fluxo d'água, propiciando assim, a ocorrência de movimentos de encosta.

Tabela 32: Índice de concentração de movimentos de encosta para as formas de encostas.

\begin{tabular}{|c|c|c|c|c|c|}
\hline \multirow{2}{*}{ Formas de encosta } & \multicolumn{2}{|c|}{ Área } & \multicolumn{2}{|c|}{ Movimentos de Encosta } & \multirow{2}{*}{$\begin{array}{c}\text { Índice de concentração } \\
\left(\text { eventos } / \mathrm{Km}^{2}\right)\end{array}$} \\
\hline & $\left(\mathrm{Km}^{2}\right)$ & $\%$ & $\mathbf{N}^{\mathbf{o}}$ & $\%$ & \\
\hline Coletora & 55,58 & 37,3 & 24 & 70,6 & 0,43 \\
\hline Plana & 18,81 & 12,6 & 0 & 0,0 & 0,00 \\
\hline Dispersora & 74,58 & 50,1 & 10 & 29,4 & 0,13 \\
\hline
\end{tabular}

Como o esperado, as declividades acima de $33 \%$ são as mais críticas, onde $61,8 \%$ dos eventos ocorrem nesta faixa (Tabela 33). Como a área ocupada por estas declividades são muito pequenas, o seu índice de concentração é 8 vezes maior que o somatório dos índices das classes restantes, portanto, fica claro como a declividade é um fator determinante para a ocorrência destes eventos.

Tabela 33: Índice de concentração de movimentos de encosta para as classes de declividades.

\begin{tabular}{c|c|c|c|c|c}
\hline \multirow{2}{*}{ Declividades (\%) } & \multicolumn{2}{|c|}{ Área } & \multicolumn{2}{c|}{ Movimentos de Encosta } & Índice de concentração \\
\cline { 2 - 6 } & $\left.\mathbf{( K m}^{\mathbf{2}}\right)$ & $\mathbf{\%}$ & $\mathbf{N}^{\mathbf{0}}$ & $\mathbf{\%}$ & 0,00 \\
\hline $0-5$ & 68,69 & 46,1 & 0 & 8,00 & 0,06 \\
\hline $5-10$ & 52,02 & 34,9 & 3 & 11,8 & 0,18 \\
\hline $10-18$ & 21,71 & 14,6 & 4 & 17,6 & 1,14 \\
\hline $18-33$ & 5,26 & 3,5 & 6 & 61,8 & 16,21 \\
\hline$>33$ & 1,30 & 0,9 & 21 & & \\
\hline
\end{tabular}

A bacia onde há o maior índice de concentração é a da Água Quente (Tabela 34), que situa-se na porção sul da área, justamente onde localiza-se a serra de Aracy.

Tabela 34: Quantificação de movimentos de encostas por bacias.

\begin{tabular}{c|c|c}
\hline Bacias & Área $\left(\mathbf{K m}^{\mathbf{2}}\right)$ & ${\text { Eventos } / \mathbf{K m}^{\mathbf{2}}}^{\mathbf{2}}$ \\
\hline Bacia do Alto Monjolinho & 26,38 & 0,04 \\
\hline Bacia do Feijão & 11,93 & 0,08 \\
\hline Bacia do Gregório & 18,34 & 0,05 \\
\hline Bacia do Baixo Monjolinho & 41,10 & 0,24 \\
\hline Bacia do Mineirinho & 5,83 & 0,00 \\
\hline Bacia do Quilombo & 2,81 & 0,00 \\
\hline Bacia do Tijuco Preto & 3,53 & 0,00 \\
\hline Bacia Santa Maria Madalena & 11,29 & 0,00 \\
\hline Bacia da Água Quente & 12,92 & 1,55 \\
\hline Bacia da Água Fria & 12,31 & 0,00 \\
\hline Bacia do Médio Monjolinho & 2,54 & 0,39 \\
\hline
\end{tabular}

A Figura 34, apresenta o mapa de concentração de movimentos de encosta. Os eventos se concentram na serra de Aracy, onde as declividades são maiores que 33\%, a vegetação é nativa, e ocorre o contato entre os compartimentos Serra Geral e Botucatu. 


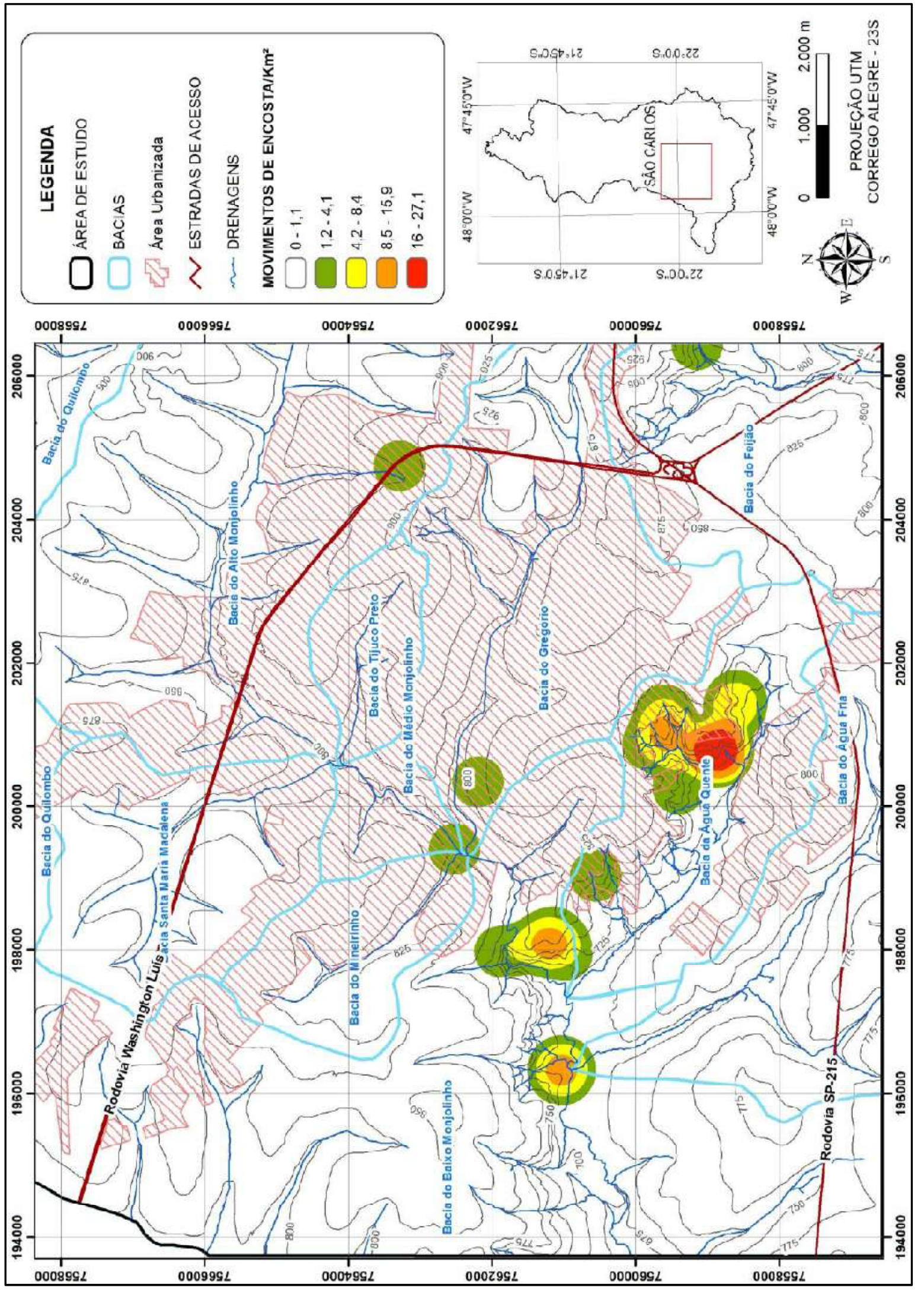

Figura 34: Mapa de concentração dos movimentos de encosta em São Carlos - SP 


\subsubsection{Processos erosivos}

Foi analisado o número de processos erosivos, por cada classe dos seguintes condicionantes: uso e ocupação; compartimentos geotécnicos; forma de encostas e declividades. Vale ressaltar que o interesse desta pesquisa são as erosões pluviais, porém também foram identificadas erosões fluviais, que foram incluídas nesta quantificação inicial. Para o mapa de suscetibilidade considerou-se apenas as erosões pluviais.

Observando a Tabela 35, nota-se que o uso com a maior quantidade de eventos e maior IC, é a área urbana, sendo que 75,0\% dos processos erosivos ocorrem nesta classe, seguido pelos fragmentos de mata e área de expansão. Apesar de normalmente a vegetação proteger o solo de erosões, os pontos onde foram registrados esses processos, são caracterizados por declividades mais elavadas. Oito erosões $(9,1 \%)$ ocorrem na área de expansão, ou seja, regiões que podem vir a ser ocupadas no futuro, necessitando um maior cuidado no manejo, quando isto vier a ocorrer.

Tabela 35: Índice de concentração de processos erosivos para as classes de uso e ocupação.

\begin{tabular}{c|c|c|c|c|c}
\hline \multirow{2}{*}{ Uso e ocupação } & \multicolumn{2}{|c|}{ Área } & \multicolumn{2}{|c|}{ Erosões } & \multirow{2}{*}{ Índice de concentração $\left(\mathbf{e v e n t o s} / \mathbf{K} \mathbf{m}^{\mathbf{2}}\right)$} \\
\cline { 2 - 6 } & $\left(\mathbf{K m}^{\mathbf{2}}\right)$ & $\mathbf{\%}$ & $\mathbf{N}^{\mathbf{0}}$ & $\mathbf{\%}$ & 0,00 \\
\hline Agricultura & 38,67 & 26,0 & 0 & 0,0 & 0,33 \\
\hline Área de expansão & 24,57 & 16,4 & 8 & 9,1 & 1,22 \\
\hline Área urbana & 54,30 & 36,5 & 66 & 75,0 & 0,68 \\
\hline Fragmento de Mata & 17,59 & 11,8 & 12 & 13,6 & 0,00 \\
\hline Industria & 1,85 & 1,2 & 0 & 0,00 & 0,17 \\
\hline Reflorestamento & 11,99 & 8,1 & 2 & 2,3 & \\
\hline
\end{tabular}

Quanto ao compartimento geotécnico, o com mais ocorrências é o Itaqueri (44,3\%), seguido pelo Serra Geral e Botucatu, porém o com maior índice de concentração é o Serra Geral, em consequência da pequena área que este compartimento ocupa na região (Tabela 36).

Entre os compartimentos que estão na região, o menos propício a ocorrência de erosões pluviais é o Serra Geral, por possuir um solo basicamente argiloso (alta coesão), ao contrário dos mais favoráveis Itaqueri (arenoso com presença de finos) e Botucatu (arenoso). Solos arenosos, devido a porosidade alta e a sua coesão zero ou próxima disso, são mais fáceis de erodirem. Arenitos do compartimento Botucatu, em algumas áreas, são uma exceção, por possuírem cimentação silicosa, que oblitera a porosidade primária, deixando a rocha mais resistente aos processos erosivos.

Observou-se que vários pontos de erosão inventariados no Serra Geral, estavam muito próximos das drenagens, muitas vezes nas próprias margens, indicando serem na verdade 
erosões fluviais. Ao todo 26 erosões indicaram ser fluviais, sendo que 22 delas ocorreram no Serra Geral, portanto, para erosões pluviais o Botucatu e Itaqueri são os mais críticos.

Tabela 36: Índice de concentração de processos erosivos para os compartimentos geotécnicos.

\begin{tabular}{|c|c|c|c|c|c|}
\hline \multirow{2}{*}{$\begin{array}{c}\text { Compartimentos geológico- } \\
\text { geotécnico }\end{array}$} & \multicolumn{2}{|c|}{ Área } & \multicolumn{2}{|c|}{ Erosões } & \multirow{2}{*}{$\begin{array}{c}\text { Índice de concentração } \\
\left(\text { eventos } / \mathbf{K m}^{2}\right)\end{array}$} \\
\hline & $\left(\mathbf{K m}^{2}\right)$ & $\%$ & $\mathbf{N}^{\mathbf{0}}$ & $\%$ & \\
\hline Coluvionar & 0,84 & 0,6 & 0 & 0,0 & 0,00 \\
\hline Aluvioar & 1,05 & 0,7 & 2 & 2,3 & 1,90 \\
\hline Itaqueri & 102,98 & 69,1 & 39 & 44,3 & 0,38 \\
\hline Serra Geral & 4,01 & 2,7 & 28 & 31,8 & 6,98 \\
\hline Botucatu & 40,09 & 26,9 & 19 & 21,6 & 0,47 \\
\hline
\end{tabular}

Em relação as formas de encostas, a com maior quantidade de eventos e maior índice de concentração é a coletora. Isto é consequência destas encostas concentrarem o fluxo d'água, favorecendo assim, a ocorrência de processos erosivos. Como esperado, as encostas dispersoras são as menos propicias a ocorrência de erosões, pois estas, dispersam o fluxo, favorecendo a deposição e não a erosão (Tabela 37).

Tabela 37: Índice de concentração de processos erosivos para as formas de encostas.

\begin{tabular}{|c|c|c|c|c|c|}
\hline \multirow[b]{2}{*}{ Formas de encosta } & \multicolumn{2}{|c|}{ Área } & \multicolumn{2}{|c|}{ Erosões } & \multirow{2}{*}{ Índice de concentração (eventos/ $\left.\mathrm{Km}^{2}\right)$} \\
\hline & $\left(\mathrm{Km}^{2}\right)$ & $\%$ & $\mathbf{N}^{\circ}$ & $\%$ & \\
\hline Coletora & 55,58 & 37,31 & 56 & 63,6 & 1,01 \\
\hline Plana & 18,81 & 12,63 & 11 & 12,5 & 0,58 \\
\hline Dispersora & 74,58 & 50,07 & 21 & 23,9 & 0,28 \\
\hline
\end{tabular}

Quanto as declividades, a faixa com maior numero de eventos é a de 0 a $5 \%$, no entanto como citado anteriormente, várias erosões registradas são fluviais e se encaixam neste intervalo. Analisando o índice de concentração, a faixa com o maior valor, é a de 10 a $18 \%$ seguida pela de 18 a 33\%, intervalos estes, mais comuns de ocorrerem erosões pluviais (Tabela 38).

Tabela 38: Índice de concentração de processos erosivos para as classes de declividade.

\begin{tabular}{c|c|c|c|c|c}
\hline \multirow{2}{*}{ Declividades $(\boldsymbol{\%})$} & \multicolumn{2}{|c|}{ Área } & \multicolumn{2}{|c|}{ Erosões } & \multirow{2}{*}{ Índice de concentração $\left(\mathbf{e v e n t o s} / \mathbf{K m}^{\mathbf{2}}\right)$} \\
\cline { 2 - 6 } & $\left.\mathbf{( K m}^{\mathbf{2}}\right)$ & $\mathbf{\%}$ & $\mathbf{N}^{\mathbf{0}}$ & $\mathbf{\%}$ & 0,61 \\
\hline $0-5$ & 68,69 & 46,11 & 42 & 47,7 & 0,37 \\
\hline $5-10$ & 52,02 & 34,92 & 19 & 21,6 & 1,01 \\
\hline $10-18$ & 21,71 & 14,57 & 22 & 25,0 & 0,95 \\
\hline $18-33$ & 5,26 & 3,53 & 5 & 5,7 & 0,00 \\
\hline$>33$ & 1,30 & 0,87 & 0 & 0,00 & \\
\hline
\end{tabular}


A bacia com maior IC é a do Médio Monjolinho (levando em consideração todos os processos erosivos), contabilizando somente as erosões pluviais, a com maior índice de concentração passa a ser a da Água Quente, devido as maiores declividades da região de estudo se inserir nela, e grande parte de sua área ser composta pelo compartimento com características mais favoráveis a erosão pluvial, o Botucatu (Tabela 39).

Tabela 39: Quantificação de processos erosivos por bacias.

\begin{tabular}{c|c|c}
\hline Bacias & Área $\left(\mathrm{Km}^{2}\right)$ & Eventos $/ \mathrm{Km}^{2}$ \\
\hline Bacia do Alto Monjolinho & 26,38 & 0,15 \\
\hline Bacia do Feijão & 11,93 & 0,34 \\
\hline Bacia do Gregório & 18,34 & 1,58 \\
\hline Bacia do Baixo Monjolinho & 41,10 & 0,27 \\
\hline Bacia do Mineirinho & 5,83 & 0,00 \\
\hline Bacia do Quilombo & 2,81 & 0,00 \\
\hline Bacia do Tijuco Preto & 3,53 & 1,70 \\
\hline Bacia Santa Maria Madalena & 11,29 & 0,27 \\
\hline Bacia da Água Quente & 12,92 & 1,39 \\
\hline Bacia da Água Fria & 12,31 & 0,24 \\
\hline Bacia do Médio Monjolinho & 2,54 & 3,94
\end{tabular}

Na Figura 35 é possível observar uma alta taxa de concentração de eventos na porção central do município, associadas as redes de drenagens, portanto, tratam-se na maior parte das vezes, de erosões fluviais.

A um grande acúmulo de eventos na parte sul de São Carlos, mais precisamente em Cidade Aracy, que se insere sobre o compartimento Botucatu, cujo solo é bastante arenoso. Apesar de alguns dos eventos nesta região, estarem associados as redes de drenagens, o que prevalece são os de origem pluvial. 


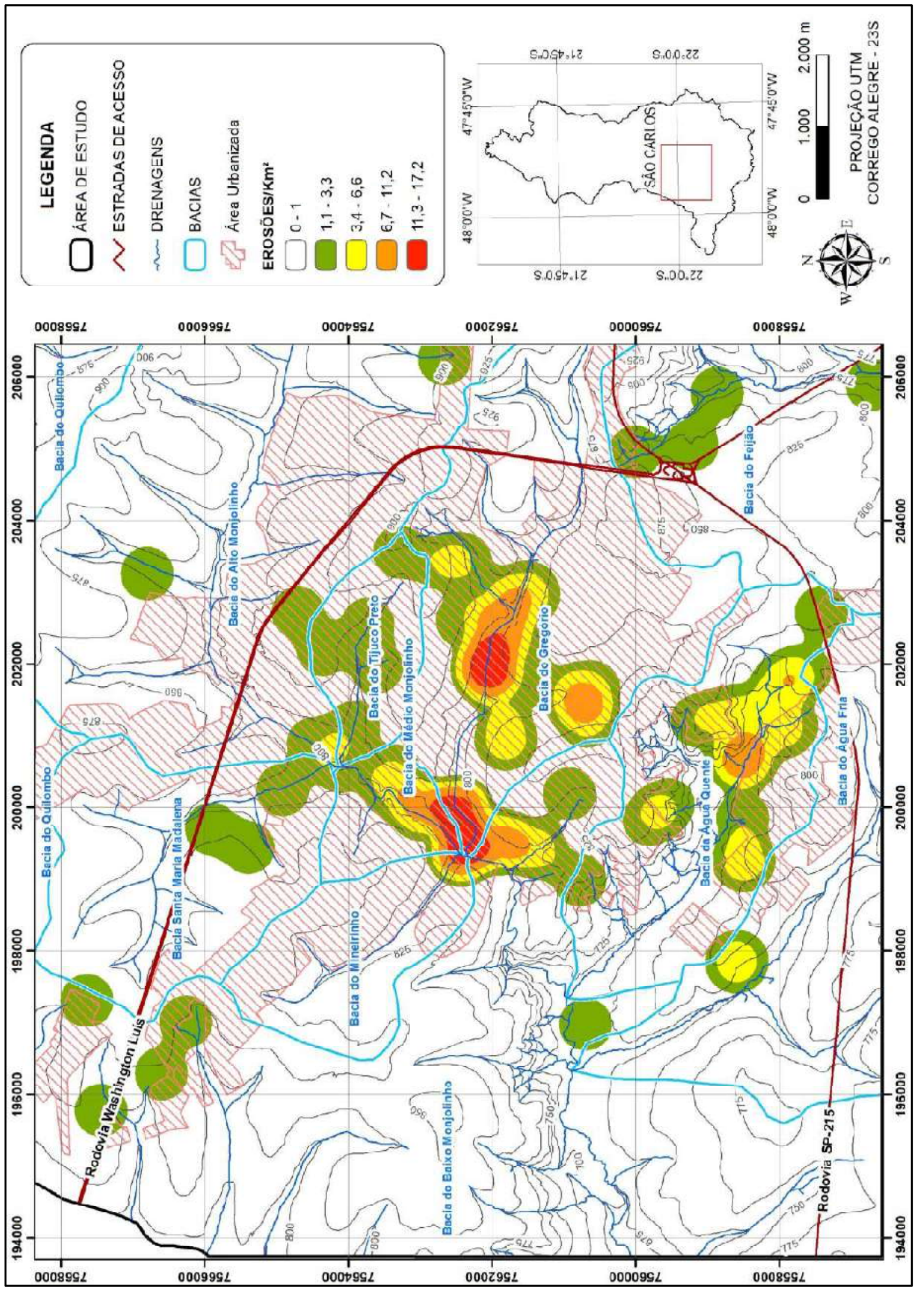

Figura 35: Mapa de concentração dos processos erosivos em São Carlos - SP 


\subsubsection{Solos colapsíveis}

Não ha registros diretos, tanto em jornais quanto na defesa civil, a respeito de solos colapsíveis, o critério adotado inicialmente, partiu do princípio que todos os casos registrados, em que casas estavam com a fundação cedendo e paredes trincando fossem consequência da colapsividade do solo.

Com base neste critério, analisou-se a quantidade de colapsos, por cada classe dos seguintes condicionantes: uso e ocupação; compartimentos geotécnicos; formas de encostas e declividades.

Como o critério adotado para identificar o colapso do solo, foi o de considerar as fundações cedendo e paredes com trincas, é de se esperar que a maioria das ocorrências ocorressem em área urbana. Observando a Tabela 40, verifica-se que 100\% dos eventos foram em área urbana, com uma concentração de 0,9 eventos $/ \mathrm{Km}^{2}$.

Tabela 40: Índice de concentração de solos colapsíveis para as classes de uso e ocupação.

\begin{tabular}{c|c|c|c|c|c}
\hline \multirow{2}{*}{ Uso e ocupação } & \multicolumn{2}{|c|}{ Área } & \multicolumn{2}{|c|}{ Colapsos } & \multirow{2}{*}{ Índice de concentração $\left(\mathbf{e v e n t o s}^{2} / \mathbf{K m}^{\mathbf{2}}\right)$} \\
\cline { 2 - 6 } & $\left(\mathbf{K m}^{\mathbf{2}}\right)$ & $\mathbf{\%}$ & $\mathbf{N}^{\mathbf{0}}$ & $\mathbf{\%}$ & 0,00 \\
\hline Agricultura & 38,67 & 26,0 & 0 & 0,0 & 0,00 \\
\hline Área de expansão & 24,57 & 16,4 & 0 & 0,0 & 0,90 \\
\hline Área Urbana & 54,30 & 36,5 & 49 & 100,0 & 0,00 \\
\hline Fragmento de Mata & 17,59 & 11,8 & 0 & 0,0 & 0,00 \\
\hline Industria & 1,85 & 1,2 & 0 & 0,0 & 0,00 \\
\hline Reflorestamento & 11,99 & 8,1 & 0 & 0,0 & \\
\hline
\end{tabular}

Quanto ao compartimento geotécnico, o com mais ocorrências é o Itaqueri $(93,9 \%)$, seguido pelo Botucatu e Serra Geral (Tabela 41).

Tabela 41: Índice de concentração de solos colapsíveis para os compartimentos geotécnicos.

\begin{tabular}{c|c|c|c|c|c}
\hline $\begin{array}{c}\text { Compartimentos geológico- } \\
\text { geotécnico }\end{array}$ & \multicolumn{2}{|c|}{ Área } & \multicolumn{2}{|c|}{ Colapsos } & \multirow{2}{*}{$\begin{array}{c}\text { Índice de concentração } \\
\left(\mathbf{e v e n t o s} / \mathbf{K m}^{\mathbf{2}}\right)\end{array}$} \\
\cline { 2 - 5 } & $\left.\mathbf{( K m}^{\mathbf{2}}\right)$ & $\mathbf{\%}$ & $\mathbf{N}^{\mathbf{0}}$ & $\mathbf{\%}$ & 0,00 \\
\hline Coluvionar & 0,8 & 0,6 & 0 & 0,0 & 0,00 \\
\hline Aluvionar & 1,1 & 0,7 & 0 & 0,0 & 0,45 \\
\hline Itaqueri & 103,0 & 69,1 & 46 & 93,9 & 0,25 \\
\hline Serra Geral & 4,0 & 2,7 & 1 & 2,0 & 0,05 \\
\hline Botucatu & 40,1 & 26,9 & 2 & 4,1 & \\
\hline
\end{tabular}

Analisando os resultados dos ensaios de granulometria e índices físicos realizados por Aguiar (1989) e Bartolomeu (2012), nas Tabelas 17 e 18 respectivamente, nota-se que o solo do compartimento Itaqueri é composto na maioria das vezes por uma areia argilo-siltosa, onde 
a proporção de argila em varias amostras é pelo menos o dobro da de silte. Dos ensaios geotécnicos, pode-se extrair algumas informações que são apresentadas na Tabela 42.

Tabela 42: Grau de saturação e porosidade de amostras do compartimento Itaqueri

\begin{tabular}{|c|c|c|}
\hline Ponto & Grau de saturação $(\%)^{2}$ & Porosidade $(\%)^{3}$ \\
\hline RA003 & 47,77 & 55,14 \\
\hline RA005 & 47,64 & 61,09 \\
\hline RA132 & 62,17 & 47,09 \\
\hline RA309 & 70,77 & 41,45 \\
\hline RA316 & 42,33 & 47,73 \\
\hline RA434 & 59,30 & 46,64 \\
\hline RA446 & 54,34 & 54,40 \\
\hline RA447 & 63,26 & 45,27 \\
\hline RA533 & 71,22 & 54,95 \\
\hline RA540 & 61,76 & 38,80 \\
\hline RA557 & 59,47 & 47,67 \\
\hline RA564 & 57,25 & 57,21 \\
\hline RA578 & 42,94 & 48,00 \\
\hline RA625 & 54,60 & 44,10 \\
\hline RA665 & 48,86 & 48,98 \\
\hline RA667 & 46,82 & 51,31 \\
\hline RA710 & 59,01 & 47,06 \\
\hline RA717 & 50,46 & 51,57 \\
\hline RA727 & 54,90 & 38,65 \\
\hline RA734 & 58,61 & 48,11 \\
\hline RA736 & 53,04 & 39,80 \\
\hline RA738 & 60,56 & 45,30 \\
\hline RA774 & 42,01 & 46,61 \\
\hline RA775 & 42,16 & 46,41 \\
\hline
\end{tabular}

Segundo Cintra (1998) o solo com um grau de saturação < 60\%, porosidade > $40 \%$ e com uma granulometria aberta (ausência de silte) pode ter o comportamento colapsível. Observando a Tabela 17, nota-se que em quase todas as análises granulométricas do compartimento Itaqueri, a fração silte é a de menor quantidade, e como mostra a Tabela 42, a maior parte das amostras apresentam características favoráveis ao comportamento de solo colapsível. Evidenciando que os registros podem ter relação com este evento.

Em relação as formas de encostas (Tabela 43), não há o predomínio de nenhuma classe quanto ao índice de concentração, mostrando que este condicionante não é

\footnotetext{
${ }^{2}$ Obtido a partir da equação $\frac{\rho_{s . w}}{e \cdot \rho_{w}}$, onde $\rho_{\mathrm{s}}=$ massa específica do sólido; $\rho_{\mathrm{w}}=$ massa específica da água e $\mathrm{w}=$ umidade

${ }^{3}$ Obtido a partir da equação $\frac{e}{1+e}$, onde $\mathrm{e}=$ índice de vazios
} 
preponderante para a ocorrência de solos colapsíveis.

Tabela 43: Índice de concentração de solos colapsíveis para as formas de encostas.

\begin{tabular}{c|c|c|c|c|c}
\hline \multirow{2}{*}{ Formas de encosta } & \multicolumn{2}{|c|}{ Área } & \multicolumn{2}{|c|}{ Colapsos } & \multirow{2}{*}{ Índice de concentração (eventos/Km $\left.\mathbf{~}^{\mathbf{2}}\right)$} \\
\cline { 2 - 6 } & $\left(\mathbf{K m}^{\mathbf{2}}\right)$ & $\mathbf{\%}$ & $\mathbf{N}^{\mathbf{0}}$ & $\mathbf{\%}$ & 0,36 \\
\hline Coletora & 55,58 & 37,3 & 20 & 40,8 & 0,32 \\
\hline Plana & 18,81 & 12,6 & 6 & 12,2 & 0,31 \\
\hline Dispersora & 74,58 & 50,1 & 23 & 47,0 & \\
\hline
\end{tabular}

Quanto a declividade (Tabela 44), a faixa que apresenta mais ocorrências é a de 0 a $5 \%$, enquanto que a com maior índice de concentração é a de 10 a $18 \%$, pois a taxa ocupada por essa classe é muito pequena. Declividades mais suaves, favorecem o colapso de solo, visto que a taxa de infiltração em relevos aplainados são maiores.

Tabela 44: Índice de concentração de solos colapsíveis para as classes de declividades.

\begin{tabular}{c|c|c|c|c|c}
\hline \multirow{2}{*}{ Declividades (\%) } & \multicolumn{2}{|c|}{ Área } & \multicolumn{2}{c|}{ Colapsos } & \multirow{2}{*}{ Índice de concentração $\left(\mathbf{e v e n t o s}^{*} / \mathbf{K m}^{\mathbf{2}}\right)$} \\
\cline { 2 - 5 } & $\left.\mathbf{( K m}^{\mathbf{2}}\right)$ & $\mathbf{\%}$ & $\mathbf{N}^{\mathbf{0}}$ & $\mathbf{\%}$ & 0,61 \\
\hline $0-5$ & 68,69 & 46,1 & 42 & 47,7 & 0,37 \\
\hline $5-10$ & 52,02 & 34,9 & 19 & 21,6 & 1,01 \\
\hline $10-18$ & 21,71 & 14,6 & 22 & 25,0 & 0,95 \\
\hline $18-33$ & 5,26 & 3,5 & 5 & 5,7 & 0,00 \\
\hline$>33$ & 1,30 & 0,9 & 0 & 0,0 & \\
\hline
\end{tabular}

A Tabela 45, apresenta o IC de solos colapsíveis por bacias, onde a com valor mais elevado é a do Médio Monjolinho, seguida pela pelo a do Gregório. A Figura 36 apresenta o mapa de concentração de solos com colapsos.

Tabela 45: Quantificação de colapso de solos por bacias.

\begin{tabular}{c|c|c}
\hline Bacias & Área $\left(\mathbf{K m}^{2}\right)$ & Eventos $/ \mathbf{K m}^{\mathbf{2}}$ \\
\hline Bacia do Alto Monjolinho & 26,38 & 0,15 \\
\hline Bacia do Feijão & 11,93 & 0,00 \\
\hline Bacia do Gregório & 18,34 & 1,20 \\
\hline Bacia do Baixo Monjolinho & 41,10 & 0,02 \\
\hline Bacia do Mineirinho & 5,83 & 0,51 \\
\hline Bacia do Quilombo & 2,81 & 0,00 \\
\hline Bacia do Tijuco Preto & 3,53 & 1,13 \\
\hline Bacia Santa Maria Madalena & 11,29 & 0,18 \\
\hline Bacia da Água Quente & 12,92 & 0,54 \\
\hline Bacia da Água Fria & 12,31 & 0,00 \\
\hline Bacia do Médio Monjolinho & 2,54 & 2,36 \\
\hline
\end{tabular}




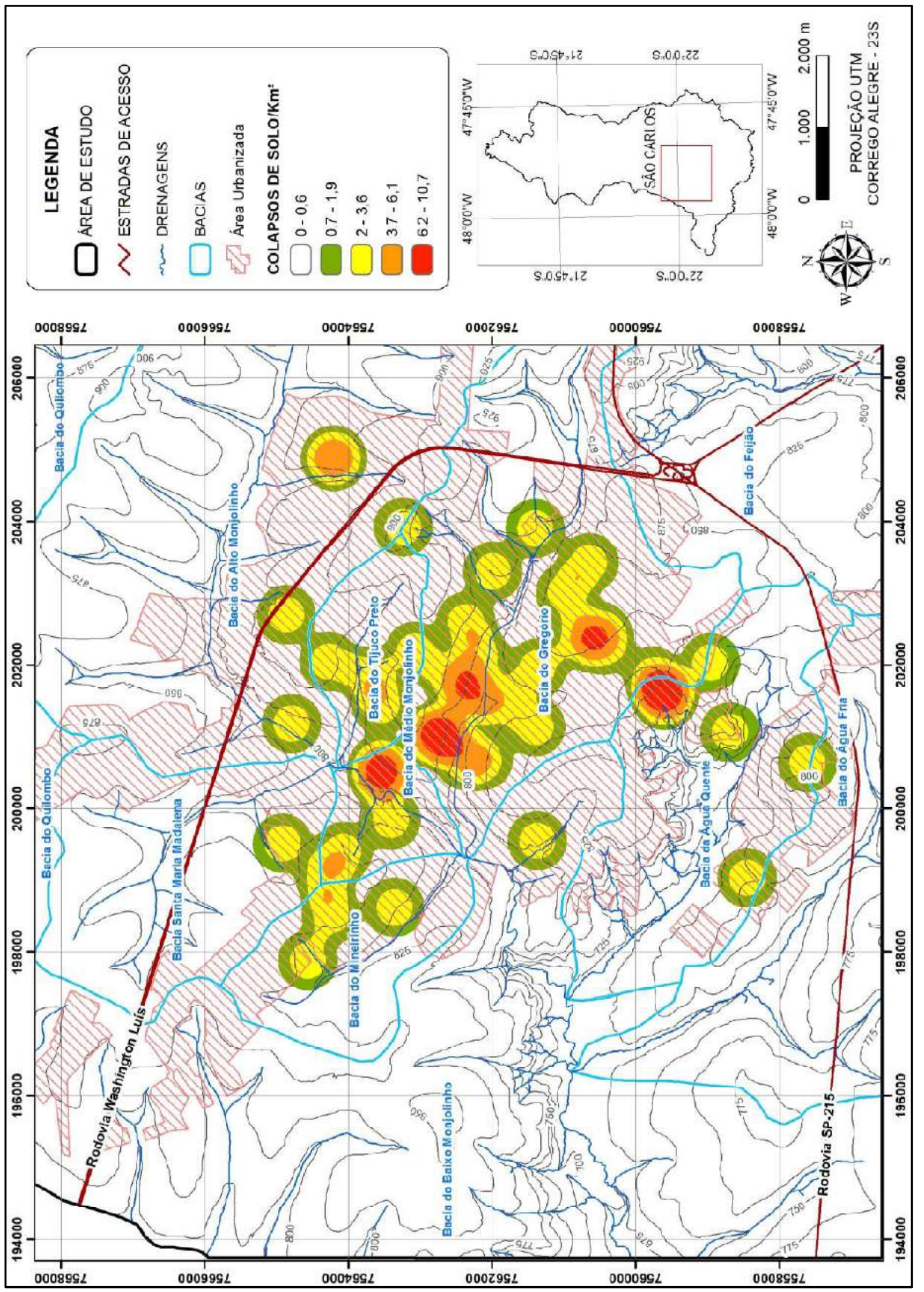

Figura 36: Mapa de concentração de colapso de solos em São Carlos - SP 


\subsubsection{Enchentes/inundações}

Nesta etapa, analisou-se a quantidade de enchentes/inundações por cada classe dos seguintes condicionantes: uso e ocupação; compartimentos geotécnicos; formas de encostas e declividades. Dos eventos que ocorrem em São Carlos, as encnentes/inundações são os mais críticos e o que há mais tempo causam transtornos a cidade. Locais como o mercado municipal, rotatória do cristo e kartódromo são constantemente atingidos por estes eventos. $\mathrm{Na}$ área de estudos, 100\% das ocorrências são em área urbana (Tabela 46). Vale ressaltar que encnhetes/inundações são processos naturais e podem ocorrem em áreas não habitadas, porém no município estes processos estão ligados principalmente a impermeabilização do solo, canalização do fluxo e obstruções ao escoamento.

Tabela 46: Índice de concentração de enchentes/inundações para as classes de uso e ocupação.

\begin{tabular}{c|c|c|c|c|c}
\hline \multirow{2}{*}{ Uso e ocupação } & \multicolumn{2}{|c|}{ Área } & \multicolumn{2}{c|}{ Enchente/Inundação } & \multirow{2}{*}{ Índice de concentração $\left(\mathbf{e v e n t o s} / \mathbf{K} \mathbf{m}^{\mathbf{2}}\right)$} \\
\cline { 2 - 5 } & $\left(\mathbf{K m}^{\mathbf{2}}\right)$ & $\mathbf{\%}$ & $\mathbf{N}^{\mathbf{0}}$ & $\mathbf{\%}$ & 0,00 \\
\hline Agricultura & 38,67 & 26,0 & 0 & 0,0 & 0,00 \\
\hline Área de expansão & 24,57 & 16,4 & 0 & 0,0 & 3,83 \\
\hline Área urbana & 54,30 & 36,5 & 208 & 100,0 & 0,00 \\
\hline Fragmento de Mata & 17,59 & 11,8 & 0 & 0,0 & 0,00 \\
\hline Industria & 1,85 & 1,2 & 0 & 0,0 & 0,00 \\
\hline Reflorestamento & 11,99 & 8,1 & 0 & 0,0 & \\
\hline
\end{tabular}

Várias drenagens na região central encontram-se sobre o compartimento Serra Geral, cujo solo é argiloso e com baixa permeabilidade comparado aos solos dos outros compartimentos. Observando a Tabela 47, nota-se que 158 (76,0\%) enchentes/inundações ocorrem neste compartimento, deixando-o com um índice de concentração de 39,4 enchentes/inundações $/ \mathrm{Km}^{2}$.

Tabela 47: Índice de concentração de enchentes/inundações para os compartimentos geotécnicos.

\begin{tabular}{|c|c|c|c|c|c|}
\hline \multirow{2}{*}{$\begin{array}{c}\text { Compartimentos } \\
\text { geológico-geotécnico }\end{array}$} & \multicolumn{2}{|c|}{ Área } & \multicolumn{2}{|c|}{ Enchente/Inundação } & \multirow{2}{*}{$\begin{array}{c}\text { Índice de concentração } \\
\left(\text { eventos } / \mathrm{Km}^{2}\right)\end{array}$} \\
\hline & $\left(\mathrm{Km}^{2}\right)$ & $\%$ & $\mathbf{N}^{0}$ & $\%$ & \\
\hline Coluvionar & 0,84 & 0,6 & 0 & 0,0 & 0,00 \\
\hline Aluvionar & 1,05 & 0,7 & 0 & 0,0 & 0,00 \\
\hline Itaqueri & 102,98 & 69,1 & 50 & 24,0 & 0,49 \\
\hline Serra Geral & 4,01 & 2,7 & 158 & 76,0 & 39,40 \\
\hline Botucatu & 40,09 & 26,9 & 0 & 0,00 & 0,00 \\
\hline
\end{tabular}

As formas de encostas, demonstra ser um condicionante importante ao analisar as enchentes/inundações, visto que na Tabela 48 é possível observar que 88,4\% ocorrem em encostas do tipo coletora, cujo formato é responsável por concentrar o fluxo d'água. 
Tabela 48: Índice de concentração de enchentes/inundações para as formas de encostas

\begin{tabular}{|c|c|c|c|c|c|}
\hline \multirow{2}{*}{$\begin{array}{c}\text { Formas de } \\
\text { Encosta }\end{array}$} & \multicolumn{2}{|c|}{ Área } & \multicolumn{2}{|c|}{ Enchente/Inundação } & \multirow{2}{*}{$\begin{array}{l}\text { Índice de concentração } \\
\left(\text { eventos } / \mathrm{Km}^{2}\right)\end{array}$} \\
\hline & $\left(\mathrm{Km}^{2}\right)$ & $\%$ & $\mathbf{N}^{\circ}$ & $\%$ & \\
\hline Coletora & 55,58 & 37,3 & 184 & 88,4 & 3,31 \\
\hline Plana & 18,81 & 12,6 & 2 & 1,0 & 0,11 \\
\hline Dispersora & 74,58 & 50,1 & 22 & 10,6 & 0,29 \\
\hline
\end{tabular}

Em relação as declividades, $88,4 \%$ das enchentes/inundações, são em relevos muito suaves e quase planos, na faixa de 0 a $5 \%$ (Tabela 49). O resultado está dentro do esperado, pois, estes eventos surgem em locais de baixas declividades.

Tabela 49: Índice de concentração de enchentes/inundações para as classes de declividades.

\begin{tabular}{c|c|c|c|c|c}
\hline \multirow{2}{*}{ Declividades (\%) } & \multicolumn{2}{|c|}{ Área } & \multicolumn{2}{c|}{ Enchente/Inundação } & \multirow{2}{*}{$\begin{array}{c}\text { Índice de concentração } \\
\left(\mathbf{e v e n t o s} / \mathbf{K m}^{\mathbf{2}} \mathbf{)}\right.\end{array}$} \\
\cline { 2 - 5 } & $\mathbf{( \mathbf { K m } ^ { 2 } )}$ & $\mathbf{\%}$ & $\mathbf{N}^{\mathbf{0}}$ & $\mathbf{\%}$ & 2,68 \\
\hline $0-5$ & 68,69 & 46,1 & 184 & 9,6 & 0,38 \\
\hline $5-10$ & 52,02 & 34,9 & 20 & 2,0 & 0,18 \\
\hline $10-18$ & 21,71 & 14,6 & 4 & 0,00 & 0,00 \\
\hline $18-33$ & 5,26 & 3,5 & 0 & 0,00 & 0,00 \\
\hline$>33$ & 1,30 & 0,9 & 0 & & \\
\hline
\end{tabular}

A bacia com o maior IC é a do Médio Monjolinho (Tabela 50), onde está localizado a rotatória do cristo, região muito atingida por enchentes/inundações ao longo do tempo na cidade de São Carlos. Em seguida está a bacia do Gregório, onde situa-se o mercado municipal, local que sofre com estes eventos a mais tempo na cidade. A Figura 37 apresenta o mapa de concentração de enchentes/inundações.

Tabela 50: Quantificação das enchentes/inundações por bacias.

\begin{tabular}{c|c|c}
\hline Bacias & Área $\left(\mathbf{K m}^{\mathbf{2}}\right)$ & Eventos $/ \mathbf{K m}^{\mathbf{2}}$ \\
\hline Bacia do Alto Monjolinho & 26,38 & 0,08 \\
\hline Bacia do Feijão & 11,93 & 0,00 \\
\hline Bacia do Gregório & 18,34 & 6,49 \\
\hline Bacia do Baixo Monjolinho & 41,10 & 0,10 \\
\hline Bacia do Mineirinho & 5,83 & 0,00 \\
\hline Bacia do Quilombo & 2,81 & 0,00 \\
\hline Bacia do Tijuco Preto & 3,53 & 2,83 \\
\hline Bacia Santa Maria Madalena & 11,29 & 1,59 \\
\hline Bacia da Água Quente & 12,92 & 0,00 \\
\hline Bacia da Água Fria & 12,31 & 0,00 \\
\hline Bacia do Médio Monjolinho & 2,54 & 21,65 \\
\hline
\end{tabular}




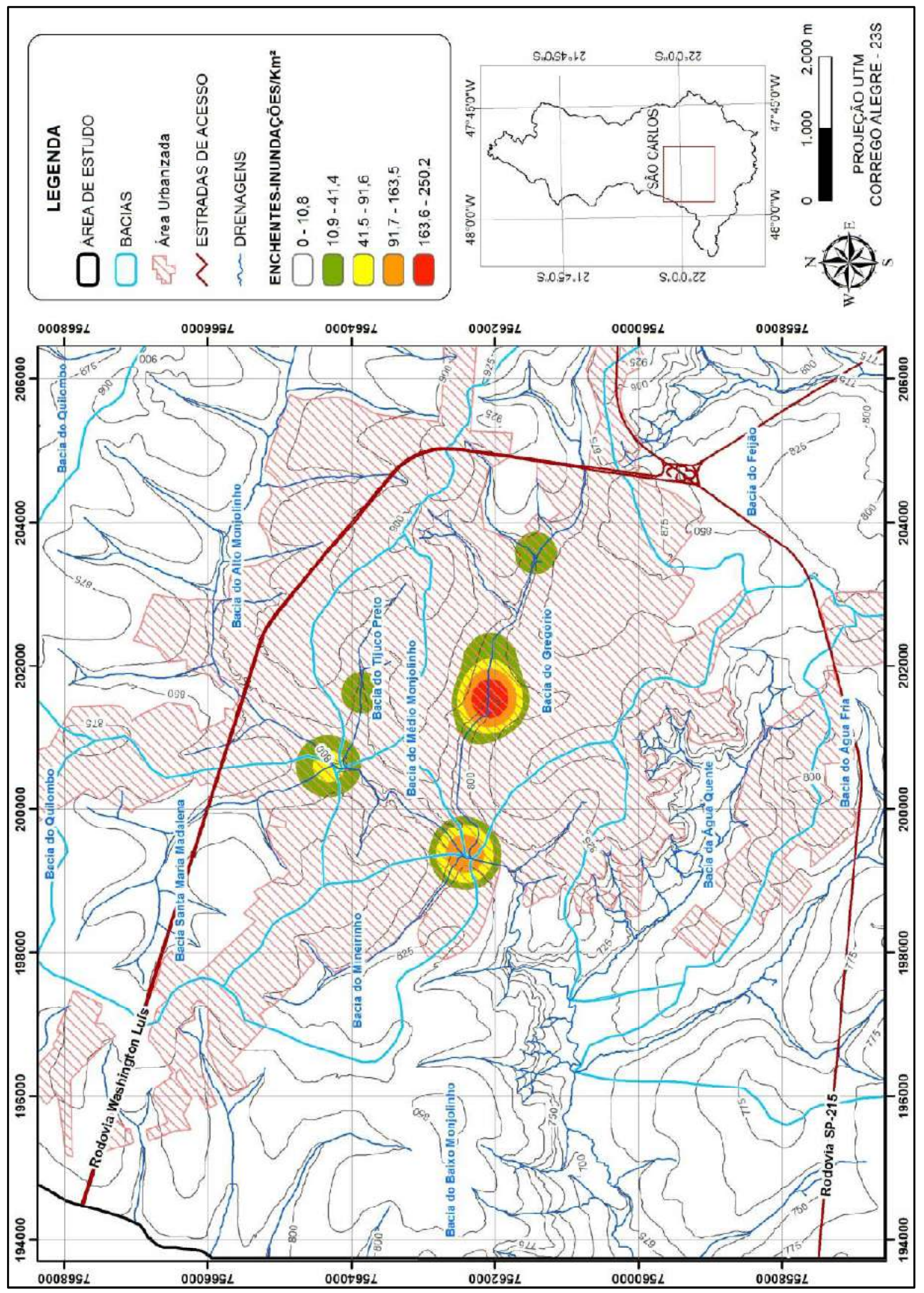

Figura 37: Mapa de concentração das enchentes/inundações em São Carlos - SP 


\subsubsection{Alagamentos}

Foi analisado a quantidade de alagamentos, por cada classe dos seguintes condicionantes: uso e ocupação; compartimentos geotécnicos; formas das encostas e declividades.

Alagamentos, ocorrem essencialmente em áreas urbanas, pois, estão diretamente relacionados a impermeabilização excessiva do solo em conjunto com um crescimento urbano sem planejamento. Para a área de estudos, 103 alagamentos (100\%) ocorreram na área urbana (Tabela 51). Os pontos com maior freqüência são na praça Itália e rotatória do CDHU

Tabela 51: Índice de concentração de alagamentos para as classes de uso e ocupação.

\begin{tabular}{c|c|c|c|c|c}
\hline \multirow{2}{*}{ Uso e ocupação } & \multicolumn{2}{|c|}{ Área } & \multicolumn{2}{c|}{ Alagamento } & \multirow{2}{*}{ Índice de concentração $\left(\mathbf{e v e n t o s} / \mathbf{K m}^{\mathbf{2}}\right)$} \\
\cline { 2 - 6 } & $\left(\mathbf{K m}^{\mathbf{2}}\right)$ & $\mathbf{\%}$ & $\mathbf{N}^{\mathbf{0}}$ & $\mathbf{\%}$ & 0,00 \\
\hline Agricultura & 38,67 & 25,96 & 0 & 0,00 & 0,00 \\
\hline Área de expansão & 24,57 & 16,49 & 0 & 0,00 & 1,90 \\
\hline Área urbana & 54,30 & 36,45 & 103 & 100,00 & 0,00 \\
\hline Fragmento de Mata & 17,59 & 11,81 & 0 & 0,00 & 0,00 \\
\hline Industria & 1,85 & 1,24 & 0 & 0,00 & 0,00 \\
\hline Reflorestamento & 11,99 & 8,05 & 0 & 0,00 & \\
\hline
\end{tabular}

Em relação aos compartimentos geotécnicos, o Itaqueri é o que mais tem ocorrências $(87,4 \%)$ e o maior índice de concentração $\left(0,87\right.$ eventos $\left./ \mathrm{Km}^{2}\right)$. Isto é consequência de que, quase toda a área urbana de São Carlos se insere sobre este compartimento (Tabela 52).

Tabela 52: Índice de concentração de alagamentos para os compartimentos geotécnicos.

\begin{tabular}{c|c|c|c|c|c}
\hline $\begin{array}{c}\text { Compartimentos } \\
\text { geotécnicos }\end{array}$ & \multicolumn{2}{|c|}{ Área } & \multicolumn{2}{|c|}{ Alagamento } & $\begin{array}{c}\text { Índice de concentração } \\
\left(\mathbf{e v e n t o s} / \mathbf{K m}^{\mathbf{2}}\right)\end{array}$ \\
\cline { 2 - 6 } & $\mathbf{( \mathbf { K m } ^ { 2 } )}$ & $\mathbf{\%}$ & $\mathbf{N}^{\mathbf{0}}$ & $\mathbf{\%}$ & 0,00 \\
\hline Coluvionar & 0,84 & 0,6 & 0 & 0,0 & 0,00 \\
\hline Aluvionar & 1,05 & 0,7 & 0 & 0,0 & 0,87 \\
\hline Itaqueri & 102,98 & 69,1 & 90 & 87,4 & 0,00 \\
\hline Serra Geral & 4,01 & 2,7 & 0 & 0,0 & 0,32 \\
\hline Botucatu & 40,09 & 26,9 & 13 & 12,6 & \\
\hline
\end{tabular}

Observando a Tabela 53, nota-se que 50,6\% dos alagamentos ocorrem em encostas coletoras, o que é de se esperar, pois, estas encostas concentram o fluxo de água. Vale ressaltar que este efeito é potencializado em uma superfície impermeabilizada. 
Tabela 53: Índice de concentração de alagamentos para as formas de encostas.

\begin{tabular}{|c|c|c|c|c|c|}
\hline \multirow[b]{2}{*}{ Formas de encosta } & \multicolumn{2}{|c|}{ Área } & \multicolumn{2}{|c|}{ Alagamento } & \multirow{2}{*}{ Índice de concentração $\left(\right.$ eventos $\left./ \mathbf{K m}^{2}\right)$} \\
\hline & $\left(\mathrm{Km}^{2}\right)$ & $\%$ & $\mathbf{N}^{\mathbf{o}}$ & $\%$ & \\
\hline Coletora & 55,58 & 37,3 & 52 & 50,5 & 0,94 \\
\hline Plana & 18,81 & 12,6 & 14 & 13,6 & 0,74 \\
\hline Dispersora & 74,58 & 50,1 & 37 & 35,9 & 0,50 \\
\hline
\end{tabular}

Em relação as declividades (Tabela 54), 95,1\% dos eventos são em faixas de 0 a 10\%, onde o surgimento de alagamentos, é mais favorável. A Tabela 55 apresenta a quantificação destes eventos em relação as bacias. A bacia do Gregório que, por se situar na área central, e por tanto ser a mais urbanizada e impermeabilizada, é a que apresenta o maior IC. A Figura 38 apresenta o mapa de concentração de alagamentos.

Tabela 54: Índice de concentração dos alagamentos para as classes de declividades.

\begin{tabular}{|c|c|c|c|c|c|}
\hline \multirow{2}{*}{ Declividades (\%) } & \multicolumn{2}{|c|}{ Área } & \multicolumn{2}{|c|}{ Alagamento } & \multirow{2}{*}{ Índice de concentração (eventos/ $\mathrm{Km}^{2}$} \\
\hline & $\left(\mathrm{Km}^{2}\right)$ & $\%$ & $\mathbf{N}^{\circ}$ & $\%$ & \\
\hline $0-5$ & 68,69 & 46,1 & 68 & 66,0 & 0,99 \\
\hline $5-10$ & 52,02 & 34,9 & 30 & 29,1 & 0,58 \\
\hline $10-18$ & 21,71 & 14,6 & 5 & 4,9 & 0,23 \\
\hline $18-33$ & 5,26 & 3,5 & 0 & 0,0 & 0,00 \\
\hline$>33$ & 1,30 & 0,9 & 0 & 0,0 & 0,00 \\
\hline
\end{tabular}

Tabela 55: Quantificação dos alagamentos por bacias.

\begin{tabular}{c|c|c}
\hline Bacias & Área $\left(\mathbf{K m}^{\mathbf{2}}\right)$ & Eventos $/ \mathbf{K m}^{\mathbf{2}}$ \\
\hline Bacia do Alto Monjolinho & 26,38 & 0,11 \\
\hline Bacia do Feijão & 11,93 & 0,00 \\
\hline Bacia do Gregório & 18,34 & 4,53 \\
\hline Bacia do Baixo Monjolinho & 41,10 & 0,00 \\
\hline Bacia do Mineirinho & 5,83 & 0,00 \\
\hline Bacia do Quilombo & 2,81 & 0,00 \\
\hline Bacia do Tijuco Preto & 3,53 & 0,00 \\
\hline Bacia Santa Maria Madalena & 11,29 & 0,00 \\
\hline Bacia da Água Quente & 12,92 & 0,77 \\
\hline Bacia da Água Fria & 12,31 & 0,32 \\
\hline Bacia do Médio Monjolinho & 2,54 & 1,18 \\
\hline
\end{tabular}




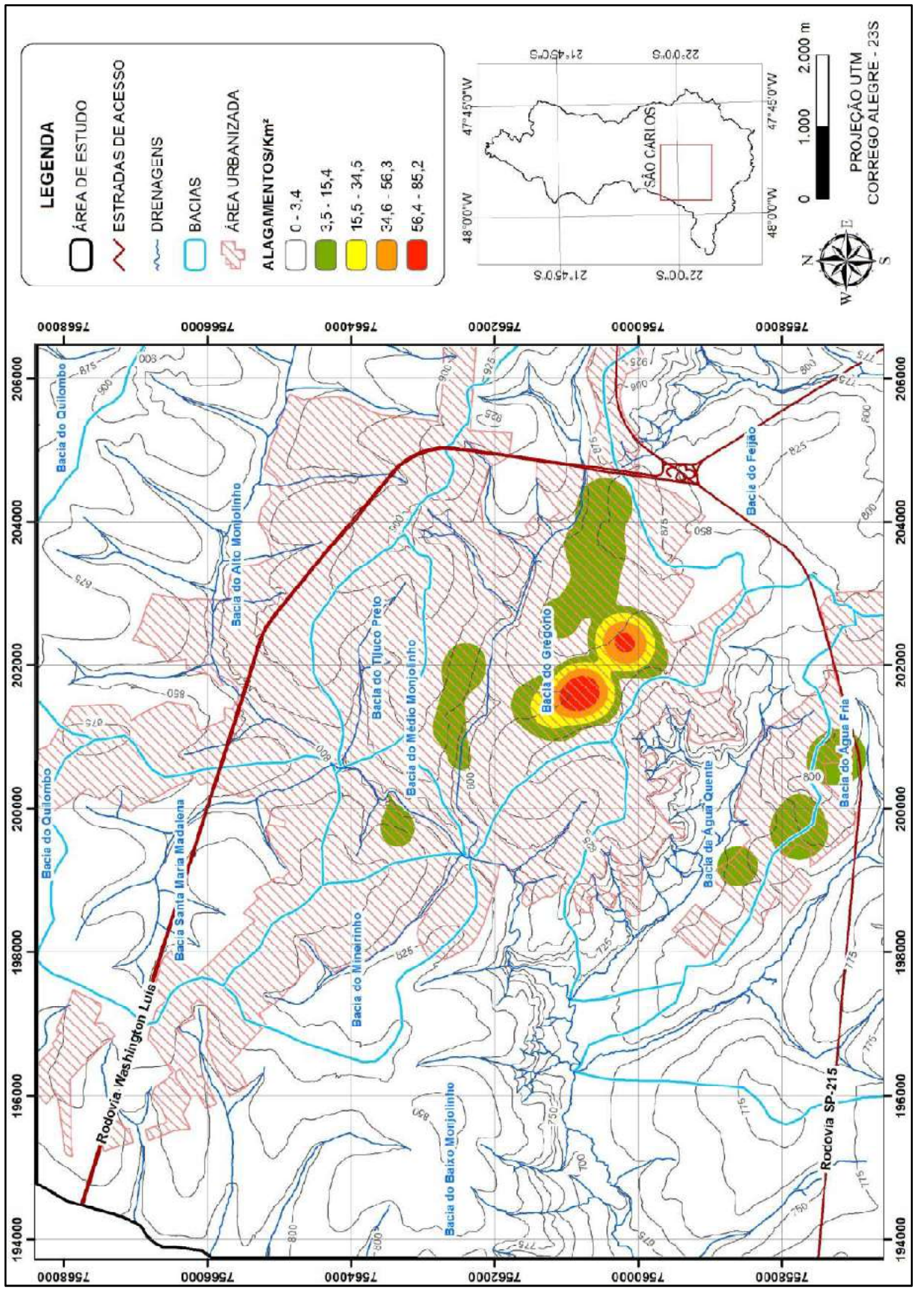

Figura 38: Mapa de concentração dos alagamentos em São Carlos - SP 


\subsection{Correlação entre Índices Pluviométricos e Eventos de Enchentes/Inundações, Alagamentos e Movimentos de Encosta}

A chuva é um agente deflagrador dos eventos registrados neste trabalho, principalmente enchentes/inundações, alagamentos, erosões e movimentos de encosta. Os eventos que foram analisados, suas datas de ocorrência, valores de precipitação acumulada em 24 horas (posto pluviométrico D4-017) e CCM correspondentes são apresentados no Anexo A.

A Figura 39 apresenta a precipitação média anual $(\mathrm{mm})$ para o município de São Carlos - SP. Nota-se que na área de estudos, na cabeceira do rio do Monjolinho, é o local que mais chove, favorecendo a ocorrência de enchentes/inundações a jusante.

Dos 482 eventos cadastrados foram selecionados 179, 103 são enchentes/inundações $(58 \%)$, 65 são alagamentos $(36 \%)$ e somente $11(6 \%)$ são movimentos de encosta. Dos eventos considerados, $23 \%$ ocorreram a uma distância de até $1 \mathrm{Km}$ do posto pluviométrico escolhido (D4-017), 72\% entre 1 e $5 \mathrm{Km}$ e apenas 5\% entre 5 e $10 \mathrm{Km}$. Portanto, a maioria dos eventos estão próximos do posto pluviométrico.

A evolução do CCM durante os anos pluviométricos de 2015-2016 é apresentado na Figura 40, evidenciando as datas de ocorrências de enchentes/inundações, alagamentos e movimentos de encosta. O CCM permanece abaixo de 1 entre junho e julho, com apenas um alagamento registrado neste período. Em julho o CCM sofre um forte aumento, subindo para 1,4 , diminuindo até setembro para menos de 1 , quando outra vez sofre um forte aumento para 1,2 e um novo alagamento ocorre. De setembro em diante O CCM sofre oscilações, porém sempre permanece acima de 1 . Vários eventos, principalmente hidrológicos são observados de novembro em diante até o final de março, isoladamente é observada uma enchente/inundação em maio com CCM mais próximo de 1. 


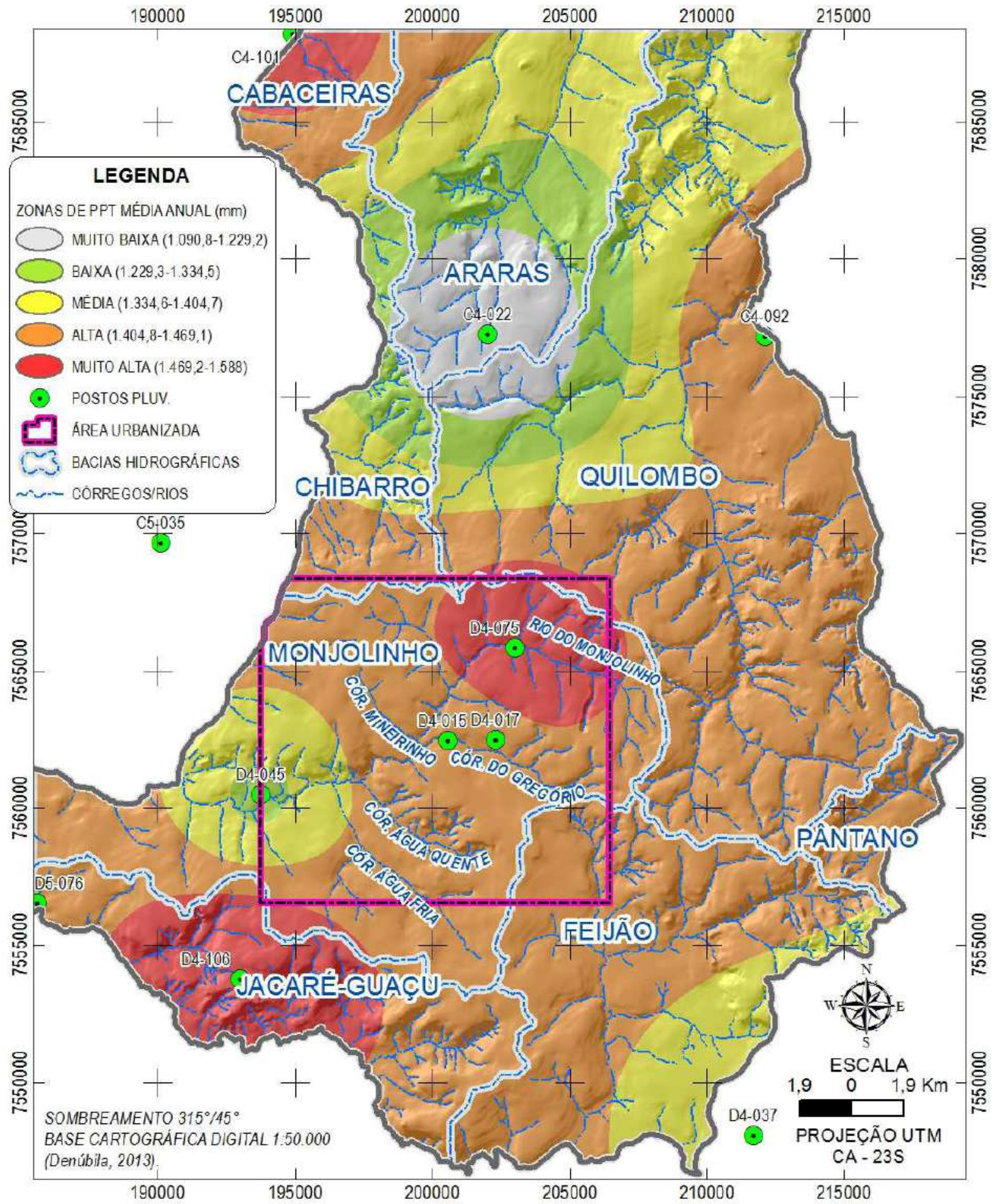

Figura 39: Precipitação média anual (mm) para o município de São Carlos - SP (SILVA JÚNIOR, 2016).

Da análise da figura, nota-se que um dos eventos ocorre com CCM inferior a 1, ou seja quando se choveu menos que o normal para o período. Isto pode ser em decorrência de chuvas isoladas porem de alta intensidade. 


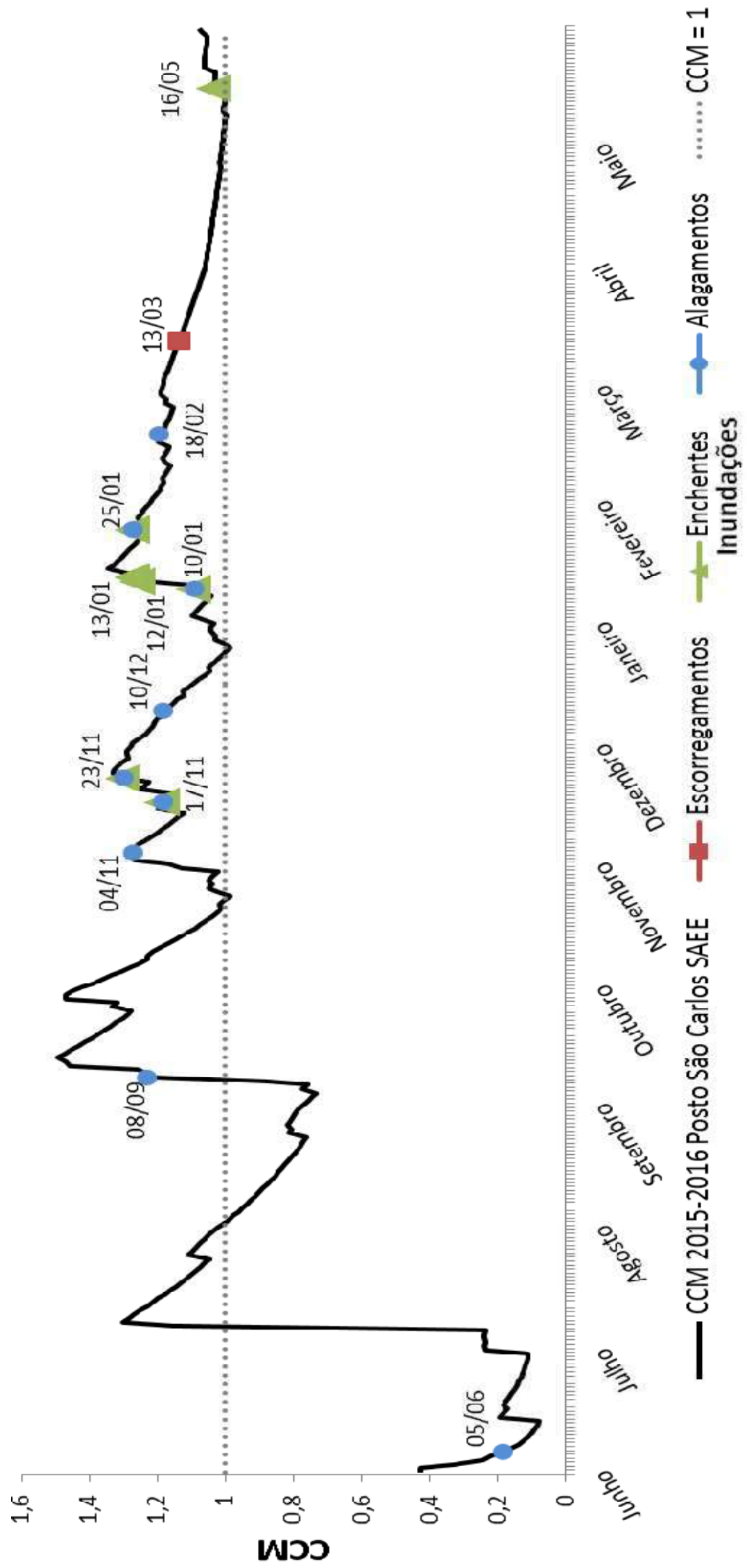

Figura 40: Evolução do CCM no ano pluviométrico de 2015 a 2016 e registro dos eventos (SILVA JUNIOR, 2016). 
A Tabela 56 exibe a distribuição dos valores de CCM totais da série histórica e dos valores em termos percentuais dos eventos registrados. Durante toda série histórica o CCM é superior a 1 em aproximadamente 50\% do tempo. Para os meses de novembro a abril, de fato, o CCM é superior a $1 \mathrm{em} 50 \%$ das vezes, considerando o posto pluviométrico utilizado (Tabela 57).

Tabela 56: Distribuição dos valores de CCM com registros de eventos e na série histórica em termos percentuais (Silva Junior, 2016).

\begin{tabular}{c|c|c|c|c}
\hline CCM & Enchentes/Inundações & Alagamentos & Movimentos de encosta & Série Histórica \\
\hline$<1$ & $23 \%$ & $28 \%$ & $64 \%$ & $54 \%$ \\
\hline$>1$ & $78 \%$ & $72 \%$ & $36 \%$ & $46 \%$ \\
\hline$>1,2$ & $51 \%$ & $35 \%$ & $9 \%$ & $24 \%$ \\
\hline
\end{tabular}

Tabela 57: Distribuição anual dos valores de CCM na série histórica (Silva Junior, 2016).

\begin{tabular}{c|c|c|c|c|c|c|c|c|c|c|c|c}
\hline CCM & Jun & Jul & Ago & Set & Out & Nov & Dez & Jan & Fev & Mar & Abr & Mai \\
\hline$<1$ & $61 \%$ & $57 \%$ & $67 \%$ & $63 \%$ & $59 \%$ & $47 \%$ & $48 \%$ & $47 \%$ & $49 \%$ & $48 \%$ & $50 \%$ & $51 \%$ \\
\hline$>1$ & $39 \%$ & $43 \%$ & $33 \%$ & $37 \%$ & $41 \%$ & $53 \%$ & $52 \%$ & $53 \%$ & $51 \%$ & $52 \%$ & $50 \%$ & $49 \%$ \\
\hline$>1,2$ & $35 \%$ & $33 \%$ & $20 \%$ & $29 \%$ & $32 \%$ & $31 \%$ & $23 \%$ & $23 \%$ & $14 \%$ & $13 \%$ & $17 \%$ & $16 \%$ \\
\hline
\end{tabular}

Entre junho e outubro o CCM é inferior a 1 mais da metade das vezes. Valores com CCM superior a 1,2 são registrados com maior freqüência nos meses iniciais do ano pluviométrico, pois, chuvas nestes meses tendem a gerar picos de CCM.

Em relação as enchentes/inundações e alagamentos, a maioria destes eventos ocorreram em valores de CCM acima de 1, em 78\% e 72\% das vezes respectivamente, já para movimentos de encostas apenas $36 \%$ ocorreram sobre essas circunstâncias. Valores de CCM acima de 1,2 ocorrem em $51 \%$ das inundações, $35 \%$ dos alagamentos e $9 \%$ dos movimentos de encostas. Para valores de CCM menores que 1, somente $23 \%$ das inundações e $28 \%$ dos alagamentos ocorrem nesta situação, já para os movimentos de encostas, mais da metade ocorre nesta circunstância. Vale ressaltar que apesar de o CCM ser maior que 1,2 somente em $24 \%$ do tempo na série histórica, mais da metade das inundações ocorrem nestas condições.

Apesar de na maioria dos eventos registrados os valores de CCM serem maiores que 1, faz-se necessário fazer esta análise combinada com outras variáveis, principalmente considerando as ocorrências com valores inferior a 1. Desta forma, realizou-se análise em relação a precipitação diária. A Tabela 58 apresenta a distribuição dos valores de precipitação diária para os eventos registrados e série histórica. 
Tabela 58: Distribuição dos valores de precipitação diária em relação aos eventos registrados e a série histórica (SILVA JUNIOR, 2016).

\begin{tabular}{c|c|c|c|c}
\hline PPT em 24h $(\mathbf{m m})$ & Inundações & Alagamentos & Movimentos de encostas & Série histórica \\
\hline $\mathrm{PPT}<20$ & $24 \%$ & $62 \%$ & $82 \%$ & $93 \%$ \\
\hline $20<\mathrm{PPT}>40$ & $33 \%$ & $23 \%$ & $0 \%$ & $5 \%$ \\
\hline $\mathrm{PPT}>40$ & $43 \%$ & $15 \%$ & $18 \%$ & $2 \%$ \\
\hline
\end{tabular}

Em relação a série histórica, 93\% das precipitações diárias ocorrem na faixa menor que $20 \mathrm{~mm}$ diários, a maioria dos movimentos de encosta (82\%) e alagamentos (62\%) e apenas $24 \%$ das inundações ocorrem sobre estas condições. As precipitações de 20 a 40mm representam apenas 5\% da série histórica, nestas condições ocorrem 33\% das inundações e $23 \%$ dos alagamentos. Embora precipitações acima de $40 \mathrm{~mm}$ ocorram somente em $2 \%$ da série histórica, quase a metade das inundações (43\%) acontecem nesta faixa. A estas condições estão associados $15 \%$ dos alagamentos e $18 \%$ dos movimentos de encostas.

Nas análises dos dados, observou-se a ocorrência de eventos onde a precipitação diária foi igual a $0 \mathrm{~mm}$. Esta situação verifica-se em eventos mais distantes do posto pluviométrico utilizado, desta forma, a deflagração pode ter sido causada por chuvas localizadas que não foram registradas pelo posto. Mesmo assim, nessas ocasiões os valores de CCM correlativos podem ser altos, indicando um período mais chuvoso na região, ainda que nestas datas especificamente o posto tenha registrado pouca ou ausência de chuva. As precipitações iguais a 0 verificadas também podem ser consequência de falhas nos sistemas de medição.

As Figuras 41 e 42 apresentam a relação do CCM e das precipitações diárias com a ocorrência de inundações nos meses de novembro de 2015 e janeiro de 2016.

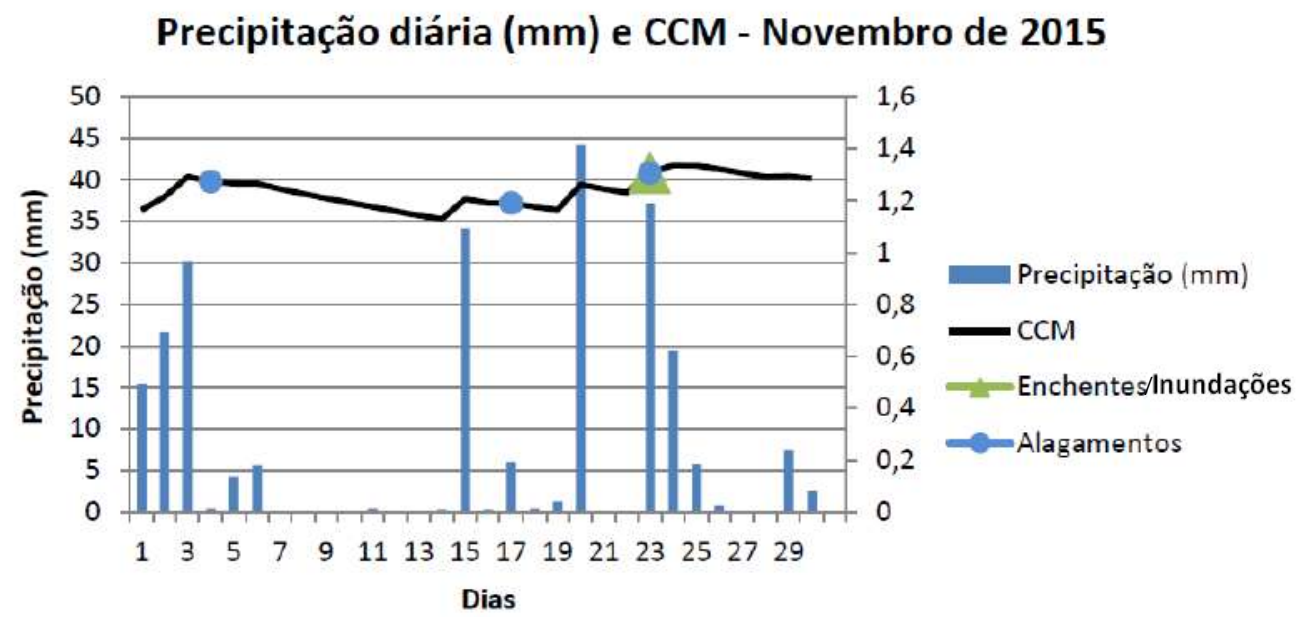

Figura 41: Precipitação diária, CCM e eventos registrados em novembro de 2015 (Silva Junior, 2016). 


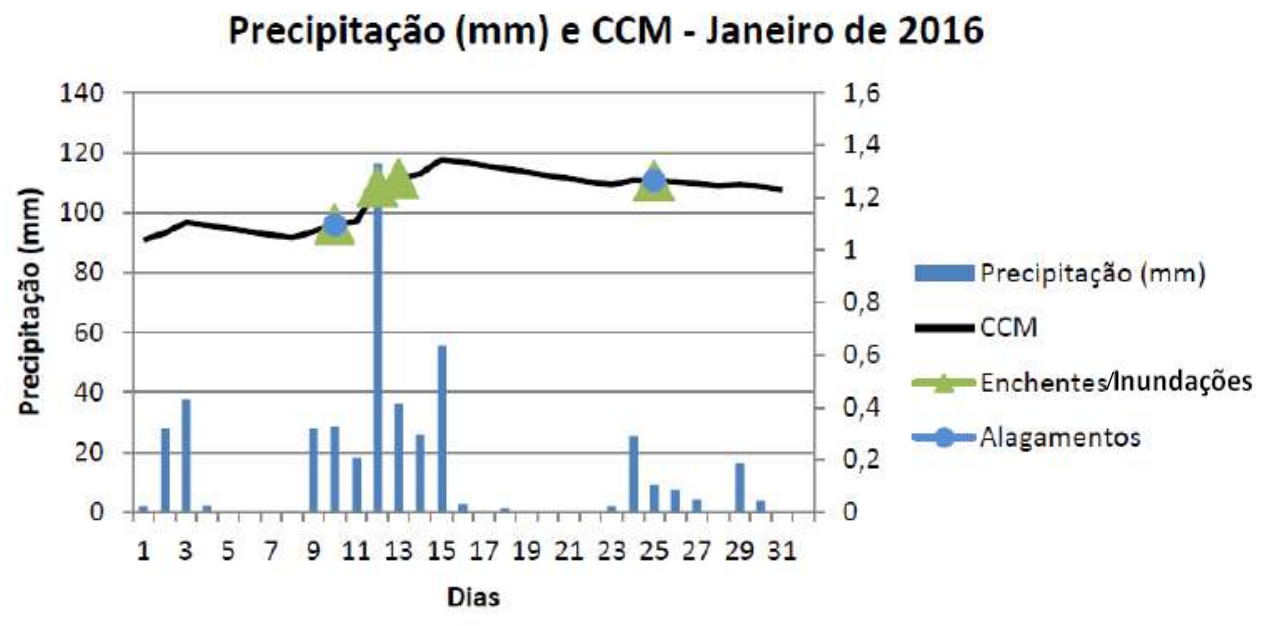

Figura 42: Precipitação diária, CCM e eventos registrados em janeiro de 2016 (Silva Junior, 2016).

A deflagração de eventos está melhor relacionada com as precipitações diárias. Notase que normalmente os eventos ocorrem em dias de precipitação diária elevada. Entretanto, alguns eventos ocorrem em precipitações diárias relativamente baixas, isto pode ocorrer devido a ausência de registro da intensidade da chuva ao longo do dia ou associadas a dias anteriores chuvosos (CCM alto). Outro ponto a se levar em conta é que chuvas concentradas por localidades podem não ser bem registradas em postos pluviométricos mais distantes da ocorrência.

\subsection{Mapas de Suscetibilidade}

Nas análises anteriores os condicionantes foram avaliados individualmente, esta primeira etapa foi importante para se ter uma idéia de como os eventos se comportam nas diversas classes de uso e ocupação; compartimentos geotécnicos; formas de encosta e declividades. Porém, sabemos que na realidade um condicionante nunca atua sozinho, portanto, para o mapeamento da suscetibilidade foi realizada uma análise em conjunto, para assim verificar quais as combinações de condicionantes são mais susceptíveis a ocorrência de cada evento.

Foi utilizado o método da sobreposição de mapas (método overlay), onde foi feito o cruzamento dos mapas temáticos para gerar o mapa de classes de terreno. Das 450 classes teóricas possíveis, verificou-se somente 305 (Apêndice C). Em seguida calculou-se o índice de suscetibilidade (eventos/classes de terreno), com estes índices gerou-se os mapas de suscetibilidade para os seguintes eventos: movimentos de encosta, erosão pluvial, colapso de 
solos e enchente/inundação. Para alagamento não foi realizado a análise de suscetibilidade, pois este é um evento muito mais relacionado ao uso e ocupação que as outras características do meio físico.

\subsubsection{Movimentos de encosta}

Para o mapa de suscetibilidade a movimentos de encostas foram verificados eventos em 17 classes de terrenos (Tabela 59). A classe de terreno com o índice de suscetibilidade (eventos $/ \mathrm{Km}^{2}$ ) maior $(161,8)$ foi a " Fragmento de Mata - Coluvionar - Coletora - 5 a 10\%", porém só um evento foi registrado nesta classe, o que contribuiu para o elevado índice foi a sua área, muito pequena, tendo pouca representatividade na região de estudos. A classe de terreno com mais eventos (9) foi a "Fragmento de Mata - Botucatu - Dispersora - > 33\%", ocupando uma área de 190.694,4 $\mathrm{m}^{2}$ e com um índice de suscetibilidade de 47,20 movimentos de encosta/ $\mathrm{Km}^{2}$.

Tabela 59: Classes de terreno com movimentos de encosta registrados.

\begin{tabular}{|c|c|c|c|}
\hline $\begin{array}{c}\text { Classe de Terreno (Uso e ocupação - compartimento } \\
\text { geológico-geotécnico - encosta - declividades) }\end{array}$ & Área $\left(\mathbf{m}^{2}\right)$ & $\begin{array}{c}\text { Movimentos de } \\
\text { encosta }\end{array}$ & $\begin{array}{c}\text { Índice de suscetibilidade } \\
\left(\text { eventos } / \mathrm{Km}^{2}\right)\end{array}$ \\
\hline Área Urbana - Itaqueri - Dispersora - 5 a $10 \%$ & 8666135,9 & 1 & 0,12 \\
\hline Área Urbana - Itaqueri - Coletora - 5 a $10 \%$ & 6517879,5 & 1 & 0,15 \\
\hline Fragmento de Mata - Botucatu - Dispersora - 10 a $18 \%$ & 1059993,5 & 1 & 0,94 \\
\hline Fragmento de Mata - Botucatu - Coletora - 10 a $18 \%$ & 1037408,2 & 2 & 1,93 \\
\hline Fragmento de Mata - Itaqueri - Coletora - 18 a 33\% & 314827,8 & 1 & 3,18 \\
\hline Área de expansão - Itaqueri - Dispersora - 18 a 33\% & 296760,7 & 1 & 3,37 \\
\hline Área Urbana - Serra Geral - Coletora - 10 a 18\% & 260087,4 & 1 & 3,84 \\
\hline Fragmento de Mata - Itaqueri - Dispersora - 18 a $33 \%$ & 452609,0 & 2 & 4,42 \\
\hline Fragmento de Mata - Serra Geral - Dispersora - > 33\% & 223858,1 & 1 & 4,47 \\
\hline Fragmento de Mata - Serra Geral - Coletora - > 33\% & 163849,1 & 1 & 6,10 \\
\hline Fragmento de Mata - Itaqueri - Coletora - > 33\% & 61796,9 & 1 & 16,18 \\
\hline Área de expansão - Serra Geral - Coletora - 18 a 33\% & 110331,4 & 2 & 18,13 \\
\hline Fragmento de Mata - Botucatu - Coletora - > 33\% & 239363,1 & 6 & 25,07 \\
\hline Área de expansão - Serra Geral - Dispersora - > 33\% & 44502,7 & 2 & 44,94 \\
\hline Fragmento de Mata - Botucatu - Dispersora - > 33\% & 190694,4 & 9 & 47,20 \\
\hline Área de expansão - Botucatu - Coletora - > 33\% & 9589,7 & 1 & 104,28 \\
\hline Fragmento de Mata - Coluvionar - Coletora - 5 a $10 \%$ & 6180,7 & 1 & 161,80 \\
\hline
\end{tabular}

Observando a Tabela 60 e o mapa de suscetibilidade a movimentos de encosta (Apêndice D) obtido a partir dos índices de suscetibilidade, nota-se que grande parte da área $(85,7 \%)$ tem a suscetibilidade muito baixa a movimentos de encosta, o que corrobora com o 
mapa de declividades (Figura 26) que mostra que a área de estudo possui um relevo suave e com declividades acima de $33 \%$ cobrindo menos de $1 \%$ da região. As classes "Alta" e "Muito Alta" concentram-se parte sul da região mais precisamente na serra de Aracy, que em praticamente toda sua extensão é coberta por vegetação nativa. A presença de vegetação a princípio ajudaria na estabilidade das encostas, porém os movimentos de encosta nessas áreas estão também associados a altas declividades, evidenciando que este fator é preponderante sobre o uso do solo.

$\mathrm{Na}$ área urbanizada o que predomina são regiões de muito baixa e baixa suscetibilidade, próximo ao shopping e ao SESC há pequenas regiões de média suscetibilidade. Os limites da área urbana, ao sul, sudeste e oeste, estão próximos a pequenas áreas de alta e muito alta suscetibilidade, portanto deve-se ter cuidado com a ocupação destas áreas sem que antes haja uma avaliação prévia.

Em um trabalho executado para a defesa civil, o IPT (2015) indicou como área de risco a movimentos de encosta um trecho da Serra de Aracy, corroborando os resultados apresentados no mapa.

Tabela 60: Áreas ocupadas pelas classes de suscetibilidade a movimentos de encostas.

\begin{tabular}{c|c|c}
\hline Suscetibilidade a movimentos de encostas & Área $\left(\mathbf{K m}^{\mathbf{2}}\right)$ & $\mathbf{\%}$ \\
\hline Muito baixa & 127,64 & 85,7 \\
\hline Baixa & 16,69 & 11,2 \\
\hline Média & 3,12 & 2,1 \\
\hline Alta & 1,27 & 0,8 \\
\hline Muito alta & 0,25 & 0,2 \\
\hline
\end{tabular}

\subsubsection{Erosão pluvial}

Para a gerar o mapa de suscetibilidade a erosão pluvial, primeiramente foram excluídos da análise 26 pontos caracterizados como erosão fluvial. Ao todo, foram verificados eventos em 32 classes de terrenos (Tabela 61). A classe de terreno com o índice de suscetibilidade $\left(42,56\right.$ eventos $\left./ \mathrm{Km}^{2}\right)$ maior foi a "Área Urbana - Serra Geral - Plana - O a $5 \% "$ porém só um evento foi registrado nesta classe, o que contribuiu para o elevado índice foi a sua área muito pequena. A classe de terreno com mais eventos (10) foi a "Área Urbana Itaqueri - Coletora - 0 a 5\%", ocupando uma área de 7.418.255,6 $\mathrm{m}^{2}$ e com um índice de suscetibilidade de 1,35 eventos $/ \mathrm{Km}^{2}$. 
Tabela 61: Classes de terreno com erosões pluviais registradas.

\begin{tabular}{|c|c|c|c|}
\hline $\begin{array}{c}\text { Classe de Terreno (Uso e ocupação - compartimento } \\
\text { geológico-geotécnico - encosta - declividade) }\end{array}$ & Área $\left(\mathbf{m}^{2}\right)$ & Erosões Pluviais & $\begin{array}{c}\text { Índice de suscetibilidade } \\
\left(\text { eventos } / \mathrm{Km}^{2}\right)\end{array}$ \\
\hline Área Urbana - Itaqueri - Dispersora - 0 a 5\% & 13137835,2 & 2 & 0,15 \\
\hline Área de expansão - Itaqueri - Dispersora - 5 a 10\% & 2525445,0 & 1 & 0,40 \\
\hline Área de expansão - Itaqueri - Coletora - 0 a 5\% & 2138397,3 & 1 & 0,47 \\
\hline Área Urbana - Itaqueri - Dispersora - 5 a $10 \%$ & 8666135,9 & 5 & 0,58 \\
\hline Área Urbana - Itaqueri - Plana - 0 a 5\% & 5011805,6 & 3 & 0,60 \\
\hline Área de expansão - Itaqueri - Dispersora - 0 a 5\% & 3320289,2 & 2 & 0,60 \\
\hline Área Urbana - Itaqueri - Coletora - 5 a 10\% & 6517879,5 & 5 & 0,77 \\
\hline Área de expansão - Botucatu - Dispersora - 10 a 18\% & 1248893,7 & 1 & 0,80 \\
\hline Área de expansão - Itaqueri - Dispersora - 10 a 18\% & 1220967,3 & 1 & 0,82 \\
\hline Fragmento de Mata - Botucatu - Coletora - 5 a $10 \%$ & 1209490,4 & 1 & 0,83 \\
\hline Área de expansão - Itaqueri - RetilÝnea - 0 a 5\% & 1115436,2 & 1 & 0,90 \\
\hline Área Urbana - Itaqueri - Coletora - 10 a 18\% & 2042202,7 & 2 & 0,98 \\
\hline Área de expansão - Botucatu - Coletora - 10 a 18\% & 971159,4 & 1 & 1,03 \\
\hline Área Urbana - Itaqueri - Coletora - 0 a 5\% & 7418255,6 & 10 & 1,35 \\
\hline Área Urbana - Itaqueri - Plana - 5 a 10\% & 1439680,3 & 2 & 1,39 \\
\hline Área Urbana -Botucatu - Coletora - 0 a 5\% & 606528,7 & 1 & 1,65 \\
\hline Fragmento de Mata - Botucatu - Dispersora - 0 a 5\% & 585259,0 & 1 & 1,71 \\
\hline Fragmento de Mata - Botucatu - Dispersora - 10 a 18\% & 1059993,5 & 2 & 1,89 \\
\hline Fragmento de Mata - Botucatu - Coletora - 10 a $18 \%$ & 1037408,2 & 2 & 1,93 \\
\hline Área Urbana - Itaqueri - Dispersora - 10 a 18\% & 2539890,8 & 5 & 1,97 \\
\hline Fragmento de Mata - Botucatu - Dispersora - 18 a 33\% & 480567,8 & 1 & 2,08 \\
\hline Reflorestamento - Botucatu - Coletora - 5 a $10 \%$ & 409388,3 & 1 & 2,44 \\
\hline Reflorestamento - Itaqueri - Dispersora - 10 a $18 \%$ & 404404,3 & 1 & 2,47 \\
\hline Área Urbana -Botucatu - Dispersora - 10 a 18\% & 352732,2 & 1 & 2,84 \\
\hline Área Urbana -Botucatu - Coletora - 5 a 10\% & 1022674,2 & 3 & 2,93 \\
\hline Área Urbana -Botucatu - Coletora - 10 a $18 \%$ & 314932,0 & 1 & 3,18 \\
\hline Área Urbana - Itaqueri - Coletora - 18 a 33\% & 299828,4 & 1 & 3,34 \\
\hline Fragmento de Mata - Serra Geral - Coletora - 18 a 33\% & 231375,6 & 1 & 4,32 \\
\hline Fragmento de Mata - Botucatu - Plana - 0 a 5\% & 158763,8 & 1 & 6,30 \\
\hline Fragmento de Mata - Botucatu - Plana - 10 a $18 \%$ & 68936,3 & 1 & 14,51 \\
\hline Área Urbana -Botucatu - Coletora - 18 a 33\% & 25811,0 & 1 & 38,74 \\
\hline Área Urbana - Serra Geral - Plana - 0 a 5\% & 23495,8 & 1 & 42,56 \\
\hline
\end{tabular}

Observando a Tabela 62 e o mapa de suscetibilidade a erosões pluviais (Apêndice E) obtido a partir dos índices de suscetibilidade, nota-se que grande parte da área de estudos tem a suscetibilidade muito baixa $(52,60 \%)$ a erosões pluviais. A área urbana demonstra ser um condicionante preponderante, visto que as áreas de suscetibilidade muito baixa concentramse fora da área urbanizada. Muitos dos processos erosivos ocorrem em faixas menores de 
declividades, portanto, o que pode estar influenciando na deflagração destas erosões é o manejo inadequado do solo. Locais com alta e muito alta suscetibilidade a erosão ocupam $1,56 \%$ da área e concentram-se na região sul do mapa, mais precisamente no bairro Cidade Aracy, região onde o compartimento Botucatu (solos arenosos) se insere.

$\mathrm{Na}$ área urbana de São Carlos, o que predomina é a média suscetibilidade a erosões pluviais, reforçando mais uma vez que o uso inadequado do solo deve influenciar fortemente nestes processos.

Deve-se ressaltar que o fato de grande parte da área em torno da região urbana possuir suscetibilidade muito baixa a erosão pluvial, não queira dizer necessariamente que o solo desta região não seja suscetível a erosão. No entanto, como o mapa foi relacionado aos registros históricos, e a maioria deles ocorreram na área urbana, isto fez com que áreas periurbanas fossem consideradas pouco suscetíveis a este evento. Este resultado mostra que o método, para este evento, tem uma certa limitação de análise para fora da área urbanizada.

Tabela 62: Áreas ocupadas pelas classes de suscetibilidade a erosões pluviais.

\begin{tabular}{c|c|c}
\hline Suscetibilidade a erosões pluviais & Área $\left(\mathbf{K m}^{\mathbf{2}}\right)$ & $\mathbf{\%}$ \\
\hline Muito baixa & 78,36 & 52,6 \\
\hline Baixa & 38,61 & 25,9 \\
\hline Média & 29,68 & 19,9 \\
\hline Alta & 2,28 & 1,5 \\
\hline Muito alta & 0,05 & 0,1 \\
\hline
\end{tabular}

\subsubsection{Colapsos de solo}

Para o mapa de suscetibilidade a colapsos de solo, foram verificados eventos em 10 classes de terrenos (Tabela 63). A classe de terreno com o índice de suscetibilidade (eventos $/ \mathrm{Km}^{2}$ ) maior $(1,65)$ foi a "Área Urbana -Botucatu - Coletora - 0 a 5", no entanto somente um evento foi registrado nesta classe. A com segundo maior índice é a "Área Urbana - Itaqueri - Coletora - 5 a 10" com 9 eventos registrados. Os índice de suscetibilidade para solos colapsáveis estão muito próximos, onde a diferença do maior para o menor é menos que 1 evento/ $\mathrm{Km}^{2}$, isto demonstra que os registros estão bem espalhados na área, ou seja, não se concentram em algumas regiões.

Por se tratar de um evento predominantemente relacionado ao tipo de solo e ao uso inadequado do mesmo, as ocorrências são todas em área urbana e majoritariamente no 
compartimento Itaqueri, compartimento este que conforme a Tabela 42 possui características favoráveis a comportamento colapsível. Quanto a declividades, os eventos estão relacionados a áreas de relevo suave.

Tabela 63: Classes de terreno com colapso de solos registrados.

\begin{tabular}{l|c|c|c}
\hline $\begin{array}{c}\text { Classe de Terreno (Uso e ocupação - } \\
\text { compartimento geológico-geotécnico - encosta - } \\
\text { declividade) }\end{array}$ & Área $\left(\mathbf{m}^{\mathbf{2}}\right)$ & $\begin{array}{c}\text { Colapso de } \\
\text { solos }\end{array}$ & $\begin{array}{c}\text { Índice de suscetibilidade } \\
\left.\text { (eventos/Km } \mathbf{K}^{\mathbf{}}\right)\end{array}$ \\
\hline Área Urbana - Itaqueri - Dispersora - 0 a 5 & 13137835,2 & 9 & 0,69 \\
\hline Área Urbana - Itaqueri - Plana - 5 a 10 & 1439680,3 & 1 & 0,69 \\
\hline Área Urbana - Itaqueri - Dispersora - 10 a 18 & 2539890,8 & 2 & 0,79 \\
\hline Área Urbana - Itaqueri - Coletora - 10 a 18 & 2042202,7 & 2 & 0,98 \\
\hline Área Urbana - Itaqueri - Plana - 0 a 5 & 5011805,6 & 5 & 1,00 \\
\hline Área Urbana - Itaqueri - Coletora - 0 a 5 & 7418255,6 & 8 & 1,08 \\
\hline Área Urbana - Itaqueri - Dispersora - 5 a 10 & 8666135,9 & 10 & 1,15 \\
\hline Área Urbana -Botucatu - Dispersora - 0 a 5 & 778857,5 & 1 & 1,28 \\
\hline Área Urbana - Itaqueri - Coletora - 5 a 10 & 6517879,5 & 9 & 1,38 \\
\hline Área Urbana -Botucatu - Coletora - 0 a 5 & 606528,7 & 1 & 1,65 \\
\hline
\end{tabular}

Observando a Tabela 64 e o mapa de suscetibilidade de colapsos de solo (Apêndice F) obtido a partir dos índices de suscetibilidade, nota-se que a maioria da área de estudos $(66,6 \%)$ possui uma suscetibilidade muito baixa para o colapso do solo. As demais classes estão espalhadas na área urbana mais homogeneamente, de forma que não ha o predomínio de nenhuma delas.

Tabela 64: Áreas ocupadas pelas classes de suscetibilidade a colapso de solos.

\begin{tabular}{c|c|c}
\hline Suscetibilidade a colapso de solos & Área $\left(\mathbf{K m}^{\mathbf{2}}\right)$ & $\mathbf{\%}$ \\
\hline Muito baixa & 99,28 & 66,6 \\
\hline Baixa & 15,42 & 10,4 \\
\hline Média & 9,98 & 6,7 \\
\hline Alta & 17,15 & 11,5 \\
\hline Muito alta & 7,14 & 4,8 \\
\hline
\end{tabular}

Destaca-se no Campus I da USP que o mapa apresenta áreas de muito alta suscetibilidade ao colapso, o que esta de acordo com o trabalho de Tsuha (2003) que afirma que o solo do campo experimental de fundações da USP possui o comportamento calapsível.

As áreas de expansão urbana foram consideradas de suscetibilidade muito baixa, devido ao fato do mapa ter sido relacionado aos registros históricos, como todos eles 
ocorreram na área urbana, isto fez com que toda a área em torno da cidade possuísse suscetibilidade muito baixa ao colapso do solo. No entanto, isto não quer dizer que o solo desta região não tenha comportamento colapsível, e sim que o método, para este evento, tem uma certa restrição de análise para fora da área urbanizada.

\subsubsection{Enchentes/inundações}

Para o mapa de suscetibilidade a enchentes/inundações foram verificados eventos em 10 classes de terrenos (Tabela 65). A classe de terreno com o índice de suscetibilidade foi a "Área Urbana -Serra Geral - Coletora - 0 a 5", esta classe foi também a que mais teve eventos registrados (144). Nota-se pela quantidade de enchentes/inundações registradas, que este evento é o de maior incidência na área de estudo, e conseqüentemente o que mais gera transtornos sociais e econômicos.

O elevado índice de suscetibilidade das classes mais críticas mostram que estas ocorrências concentram-se principalmente sobre a área urbana no compartimento Serra Geral, em encosta coletora e em declividades de 0 a $5 \%$. O compartimento Serra Geral de fato é o mais propicio a ocorrência de enchentes/inundações, devido a sua composição argilosa, portanto de baixa permeabilidade, porém as notícias dos jornais mostram que o condicionante mais influente é o uso e ocupação. Obras na área urbana como a canalização dos córregos, ocupação de suas margens e impermeabilização do solo favorecem fortemente a ocorrência destes eventos.

O mapa de suscetibilidade a enchentes/inundações (Apêndice G) foi gerado apenas para as drenagens, em um raio de 50 metros para cada lado das margens, portanto o mapa mostra somente as drenagens mais suscetíveis. Ao todo, as drenagens (considerando o raio de 50 metros) ocupam $14,83 \mathrm{Km}^{2}$.

Tabela 65: Classes de terreno com enchentes/inundações registradas.

\begin{tabular}{l|c|c|c}
\hline $\begin{array}{c}\text { Classe de Terreno (Uso e ocupação - } \\
\text { compartimento geológico-geotécnico - encosta - } \\
\text { declividade) }\end{array}$ & Área $\left(\mathbf{m}^{\mathbf{2}}\right)$ & Inundações & $\begin{array}{c}\text { Índice de suscetibilidade } \\
\left(\mathbf{e v e n t o s} / \mathbf{K} \mathbf{m}^{\mathbf{2}}\right)\end{array}$ \\
\hline Reflorestamento - Itaqueri - Dispersora - 0 a 5 & 1939354,06 & 1 & 0,52 \\
\hline Área Urbana - Itaqueri - Coletora - 5 a 10 & 6517879,53 & 5 & 0,77 \\
\hline Área Urbana - Itaqueri - Dispersora - 5 a 10 & 8666135,90 & 13 & 1,50 \\
\hline Área Urbana - Serra Geral - Coletora - 10 a 18 & 260087,43 & 1 & 3,84 \\
\hline Área Urbana - Itaqueri - Coletora - 0 a 5 & 7418255,58 & 31 & 4,18 \\
\hline Área Urbana - Serra Geral - Coletora - 5 a 10 & 303152,39 & 3 & 9,90 \\
\hline Área Urbana - Serra Geral - Dispersora - 10 a 18 & 252461,17 & 3 & 11,88 \\
\hline
\end{tabular}


Tabela 65 continuação: Classes de terreno com enchentes/inundações registradas.

\begin{tabular}{l|c|c|c}
\hline $\begin{array}{c}\text { Classe de Terreno (Uso e ocupação - } \\
\text { compartimento geológico-geotécnico - encosta - } \\
\text { declividade) }\end{array}$ & Área $\left.\mathbf{( m}^{\mathbf{2}}\right)$ & Inundações & $\begin{array}{c}\text { Índice de suscetibilidade } \\
\text { (eventos/Km }\end{array}$ \\
\hline Área Urbana - Serra Geral - Dispersora - 0 a 5 & 100298,48 & 5 & 49,85 \\
\hline Área Urbana - Serra Geral - Plana - 0 a 5 & 23495,76 & 2 & 85,12 \\
\hline Área Urbana - Serra Geral - Coletora - 0 a 5 & 307531,33 & 144 & 468,24 \\
\hline
\end{tabular}

A tabela 66 mostra que $85,6 \%$ da área das drenagens possuem suscetibilidade muito baixa para enchentes/inundações, apenas 3,2\% da área têm alta ou muito alta suscetibilidade, o que deixa claro que os eventos se concentram de forma intensa em poucas regiões. As regiões mais críticas em ordem crescente são o kartódromo, rotatória do cristo e baixada do mercado municipal. Dentro da Universidade Federal de São Carlos existe uma área com alta suscetibilidade. Apesar de nesta área existir poucas ocorrências, o controle e acompanhamento da mesma, além das demais já citadas é recomendado.

Tabela 66: Áreas ocupadas pelas classes de suscetibilidade a enchentes/inundações.

\begin{tabular}{c|c|c}
\hline Suscetibilidade a enchentes/inundações & Área $\left(\mathbf{K m}^{\mathbf{2}}\right)$ & $\mathbf{\%}$ \\
\hline Muito baixa & 12,69 & 85,6 \\
\hline Baixa & 0,88 & 5,9 \\
\hline Média & 0,79 & 5,3 \\
\hline Alta & 0,18 & 1,2 \\
\hline Muito alta & 0,29 & 2,0 \\
\hline
\end{tabular}

Em um estudo realizado em 2015 pelo IPT, o órgão apontou as regiões do mercado municipal, rotatória do cristo e kartódromo como áreas de risco a enchentes/inundações, confirmando os resultados apresentados no mapa. 



\section{CONCLUSÕES}

Esta pesquisa foi realizada na área urbana e de expansão urbana de São Carlos no estado de São Paulo, e apresenta o mapeamento da suscetibilidade a eventos perigosos de natureza geológica e hidrológica para o município.

O mapa da suscetibilidade a movimentos de encosta mostrou-se coerente com as informações obtidas nos trabalhos de campo, com as características do meio físico e com o resultado de trabalhos anteriores. A região de estudo possui poucas áreas de alta ou muito alta suscetibilidade a movimentos de encosta. Os poucos eventos que ocorreram na região foram registrados como escorregamentos e em alguns locais quedas de blocos. Algumas áreas mais suscetíveis estão próximas da área urbanizada e também de áreas mais pobres, onde as construções muitas vezes são feitas de forma precária, as deixando mais vulneráveis a estes eventos. Sugere-se que haja o devido cuidado com a expansão da cidade nestas direções, afim de se evitar maiores problemas sociais e econômicos.

O mapa de suscetibilidade a erosões pluviais, também mostrou resultados congruentes com as informações obtidas nos trabalhos de campo e com as características do meio físico. $\mathrm{O}$ uso e ocupação do solo mostrou ser um condicionante preponderante nesta análise. As áreas mais suscetíveis estão localizadas ao sul da área, em um bairro mais pobre (Cidade Aracy) e vulnerável, onde já houve grandes processos erosivos. É importante monitorar esta área, pois o seu solo arenoso (compartimento Botucatu) em conjunto com uso e ocupação inadequado e instalações de infra-estrutura precárias podem vir a reativar processos erosivos outrora controlados. Vale ressaltar que este tipo de evento é mais comum na área rural e de expansão, visto que na área urbana os grandes eventos já foram controlados.

O mapa de suscetibilidade a colapso dos solos apresentou-se coeso com os dados coletados e resultados de trabalhos anteriores. Apesar de já se ter o conhecimento que o solo em São Carlos possui tal comportamento, não há registros históricos diretos de colapso do solo nos meios de pesquisa utilizados. Portanto, partiu-se do princípio que todos os registros históricos de construções com problemas nas fundações e com trincas na estrutura das casas, fossem em consequência de tal comportamento. Os parâmetros dos solos do compartimento Itaqueri, apresentaram algumas características favoráveis a colapsividade, estando coerente com o resultado obtido no mapa da suscetibilidade. 
O mapa de suscetibilidade a enchentes/inundações, apresentou resultados conexos com as características do meio físico, com as informações obtidas nos trabalhos de campo e com resultados de trabalhos anteriores. Enchentes/inundações são os eventos mais frequentes e que causam mais transtornos no município de São Carlos. A área mais crítica é a baixada do mercado municipal, onde se tem registro de grandes inundações desde o ano de 1965, a rotatória do cristo e kartódromo também são locais de grande incidência.

O uso da análise histórica dos eventos geológicos e hidrológicos, e a frequiência destes eventos, em função da área dos condicionantes cartografados nos mapas temáticos, para gerar mapas de suscetibilidade, mostrou-se satisfatório.

Verificou-se para todos os eventos, que a análise dos condicionantes sobrepostos é fundamental, visto que um condicionante desfavorável para a deflagração de um evento, quando combinado com outro condicionante, pode-se tornar favorável a deflagração, como ocorre na área de estudos com os fragmentos de mata que associados a altas declividades tornam-se suscetíveis aos movimentos de encosta.

No entanto o método possui alguma limitações, como: não considerar para os eventos a área afetada, simplificando todos os registros como ocorrências pontuais; por se basear em dados históricos e estes se concentrarem sobre a região urbanizada, a análise da suscetibilidade fora da área urbana fica prejudicada. Este fato pode ser observado principalmente para os mapas de colapso de solos e erosões pluviais.

A análise e uso dos CCMs é bastante utilizada para o estudo de suscetibilidade e perigo de movimentos de encosta e como critério de deflagração destes eventos, no entanto ela se mostrou muito eficaz quando aplicada a análise de enchentes/inundações, onde $78 \%$ destes eventos ocorreram em CCMs acima de 1 , ou seja quando choveu mais que o normal para a época. Os dados de precipitação demonstraram ser bons indicadores para inundações, onde $43 \%$ das inundações ocorreram quando houve precipitações acima de $40 \mathrm{~mm}$, apesar de estas chuvas só fazerem parte de $2 \%$ da série histórica. A aderência menor dos CCMs aos movimentos de encosta, pode ser devido aos registros terem sido obtidos também em imagens de satélite, o que prejudica a obtenção precisa das datas de ocorrência. Devido aos resultados obtidos, recomenda-se o uso dos CCMs em conjunto com os dados de precipitação diária como critério de deflagração para as inundações. 
De forma geral os objetivos sugeridos no trabalho foram cumpridos com êxito, gerando produtos coerentes, que possuem uma grande utilidade, principalmente para o plano de expansão e uso da defesa civil do município de São Carlos. Seria interessante que trabalhos deste tipo fossem mais utilizados pelas autoridade públicas.

Devido a relevância do tema para a sociedade, é importante que seja dada continuidade a pesquisa, como sugestões de prosseguimento do trabalho, sugere-se:

- Manter o banco de dados sempre atualizados, registrando os eventos perigosos que ocorrerem após esta pesquisa;

- Identificar as áreas inundáveis nas enchentes/inundações;

- Identificar a área do material escorregado nos movimentos de encosta;

- Identificar a área do material erodido nas erosões pluviais;

- Ensaiar os solos em alguns pontos descritos como de alta suscetibilidade ao colapso e comparar com os resultados no mapa;

- Verificar a eficácia da utilização do CCM em mais eventos de inundação. 



\section{REFERÊNCIAS BIBLIOGRÁFICAS}

AGUIAR, R L; GANDOLFI, N; PARAGUASSU, A B. Consideracoes gerais sobre a carta de potencial a erosao da regiao de sao carlos-sp. Anais.. São Paulo: Abge/Ipt, 1995.

AGUIAR, R. L. Mapeamento geotecnico da área de expansão urbana de São Carlos - SP : contribuicao ao planejamento. Dissertação (Mestrado em Geotecnia) - Escola de Engenharia de São Carlos, Universidade de São Paulo, São Carlos, 1989.

ALMEIDA, D. M. F. Sistemas de gestão de risco de inundações urbanas baseado em web mapping. 2010. 69 f. Monografia. Universidade de São Paulo, São Carlos, 2010.

AMARAL, R; RIBEIRO, R. R. Desastres Naturais: conhecer para prevenir. São Paulo: Imprensa Oficial do Estado de São Paulo, 2009. p. 39-53

AUGUSTO FILHO, O. - 1992. Caracterização geológico-geotécnica voltada à estabilização de encostas: uma proposta metodológica. In: CONFERÊNCIA BRASILEIRA SOBRE ESTABILIDADE DE ENCOSTAS, 1, Rio de Janeiro. Anais... Rio de Janeiro: ABMS/ABGE/PUCRJ, 1992, v.2, p.721730.

AUGUSTO FILHO, O. Carta de Risco de Escorregamentos Quantificada em Ambiente de SIG como Subsídio para Planos de Seguro em Áreas Urbanas: Um Ensaio em Caraguatatuba (SP). 196f. Tese (Doutorado - Geociências e Meio Ambiente) Universidade Estadual Paulista. Rio Claro (SP), 2001.

AUGUSTO FILHO, O. Geotecnia Ambiental: Aplicação de SIG em Geotecnia Ambiental. São Paulo: Elsevier, 2015. 25 p.

AUGUSTO FILHO, O. Geotecnia Ambiental: Escorregamentos em Encostas Naturais e Ocupadas: Análise e Controle. São Paulo: ABGE, 1995. 20 p.

AUGUSTO FILHO, O. PROJ. PETROBRÁS: Alertas Meteorológicos para Riscos GeológicoGeotécnicos. São Carlos: Petrobrás, 2016. 47 p.

BARROS, R. M. Previsão de enchentes para o plano diretor de drenagem urbana de São Carlos (PDDUSC) na bacia escola do córrego Gregório. 2005. 279 p. Tese (Doutorado). Universidade de São Paulo, São Carlos, 2005.

BARTOLOMEU, D. Análise da vulnerabilidade dos recursos hídricos na região urbana de São Carlos (SP) por vazamento em postos de combustíveis, utilizando o método GOD e avaliação dos condicionantes geotécnicos. 2012. 173 p. Dissertação (Mestrado) - Curso de Geotecnia, Universidade de São Paulo, São Carlos, 2012.

BELL, F.G. Geological Hazards. New York: Routledge, 1999. 631 p.

BENINI, R. M.; MARTIOLI, C.; MENDIONDO, E. M. Uso de SIG associado ao Método Racional para Previsão de Vazões na Bacia do Córrego do Mineirinho, São Carlos, SP. In: Simpósio de Recursos Hídricos do Centro-Oeste, 3, 2004, Goiânia, GO. Anais... Porto Alegre-São Paulo: ABRHAcquacon, 2004. v. 1. p. 1-10.

BOBROWSKY, P.; HIGHLAND, L M. The Landslide Handbook- A Guide to Understanding Landslides.1325. ed. Virginia: U.s. Geological Survey, 2008. p. 5-30. 
BORTOLUCCI, A. A. Caracterização geológico-geotécnica da região urbana de São Carlos-SP, a partir de sondagens de simples reconhecimento. Dissertação (Mestrado em Geotecnia) - Escola de Engenharia de São Carlos, Universidade de São Paulo, São Carlos, 1983.

CAMPANELLI, L. C. ZONEAMENTO (GEO)AMBIENTAL ANALÍTICO DA BACIA HIDROGRÁFICA DO RIO MONJOLINHO - SÃO CARLOS (SP). 2012. 184 f. Dissertação (Mestrado) - Curso de Engenharia Urbana, Universidade Federal de São Carlos, São Carlos, 2012.

CARNEIRO, B. J. I. Comportamento de tubulões à céu aberto, instrumentado, em solo não saturado, colapsível. 1999. 323 p. Tese (Doutorado). Universidade de São Paulo, São Carlos, 1999.

CERRI, L.E.S. - 1990. Carta geotécnica: contribuições para uma concepção voltada às necessidades brasileiras. In: CONGRESSO BRASILEIRO DE GEOLOGIA DE ENGENHARIA, 6, Salvador. Anais... Salvador: ABGE,1990. v.1, p.309-317.

CERRI, L.E.S.; MACEDO, E.S. de; OGURA, A.T.; NUNES, C.M.; CARNEIRO, S.R.R.; MODESTO, R.P. (1990). Plano preventivo de defesa civil para minimização das conseqüências de escorregamentos em municípios da Baixada Santista e Litoral Norte do Estado de São Paulo. In: SIMPÓSIO LATINO-AMERICANO SOBRE RISCO GEOLÓGICO URBANO, $1^{\circ}$., São Paulo, SP. Anais. São Paulo, ABGE, p. 395, 408.

CHLEBORAD, A. F.; BAUM, R. L.; GODT, J. W. (2006). Rainfall Thresholds for Forecasting Landslides in the Seattle, Washington, Area: Exceedance and Probability. U.S Geological Survey Open File Reoport 2006-1064.

CINTRA, J.C.A. (1998). Fundações em Solos Colapsíveis. São Carlos, SP. Projeto Reenge, Escola de Engenharia de São Carlos - USP, 116p.

CRUDEN, D.M.; VARNES, D.J. Landslide types and processes. Landslides, Investigation and mitigation. Transportation Research Board, special report 247, p.36-75, 1996.

DAEE - DEPARTAMENTO DE ÁGUAS E ENERGIA ELÉTRICA. (Org.). Portal do Departamento de Águas e Energia Elétrica. 2015. Disponível em: <http://www.hidrologia.daee.sp.gov.br/>. Acesso em: 25 abr. 2016.

DECINA, T. G. T. Análise de medidas de controle de inundações a partir da avaliação de cenários de uso e ocupação do solo na bacia hidrográfica do Córrego do Gregório, São Carlos SP. 2012. 177 p. Dissertação (Mestrado) - Curso de Geotecnia, Universidade de São Paulo, São Carlos, 2012.

DENÚBILA, L, A. Alterações Ambientais Associadas À Mineração No Município De São Carlos (Sp), Utilizando AHP e SIG. 2013. 314 p. Dissertação (Mestrado) - Curso de Geotecnia, Departamento de Geotecnia, Universidade de São Paulo, São Carlos, 2013.

DNIT - DEPARTAMENTO NACIONAL DE INFRAESTRUTURA DE TRANSPORTES. Manual de Hidrologia Básica para Estruturas de Drenagem. Diretoria de Planejamento e Pesquisa. Coordenação do Instituto de Pesquisas Rodoviárias. 2. ed. Rio de Janeiro, 2005. 133 p.

DOURADO, F. et al. O Megadesastre da Região Serrana do Rio de Janeiro - as Causas do Evento, os Mecanismos dos Movimentos de Massa e a Distribuição Espacial dos Investimentos de Reconstrução no Pós-Desastre. Anuário Igeo-Ufrj, Rio de Janeiro, v. 35, n. 2, p.43-54, dez. 2012. Instituto de Geociencias - UFRJ.

DUDLEY, J.H. Review of Collapsing Soils. Journal of the Soil Mechanics and Foundation Division, v. 96, n. SM3, p. 925-947, 1970. 
EINSTEIN, H.H. - 1988. Landslide Risk Assessment Procedure. In: INTERNATIONAL SYMPOSIUM ON LANDSLIDES, 5. Proc... .Lausanne, Switzerland, A.A. Balkema, Rotterdam, Netherlands, 1988. Vol.2, p. 1075-1090.

EM-DAT Emergency Database. OFDA/CRED - The Office of US Foreign Disaster Assistance/Centre for Research on the Epidemiology of Disasters - UniversitéCatholique de Louvain, Brussels, Belgium. Disponível em: http://www.emdat.be/ Database. Acesso em fevereiro de 2016.

EPTV (São Carlos) (Org.). Veja fotos do alagamento causado pela chuva em São Carlos, SP. 2013. Disponível em: <http://g1.globo.com/sp/sao-carlos-regiao/fotos/2013/10/veja-fotos-do-alagamentocausado-pela-chuva-em-sao-carlos-sp.html>. Acesso em: 25 jul. 2015.

ESRI (Estados Unidos da América). Data classification methods. Disponível em: <http://pro.arcgis.com/en/pro-app/help/mapping/symbols-and-styles/data-classification-methods.htm>. Acesso em: 10 mar. 2017.

ESRI (Estados Unidos da América). How Kernel Density Works. Disponível em: < http://pro.arcgis.com/en/pro-app/tool-reference/spatial-analyst/how-kernel-density-works.htm>.

Acesso em: 10 mar. 2017.

FAGUNDES, J. R. T. Estudo integrado das características geológico-geotécnicas com vista à avaliação de recarga de aquífero: região de São Carlos - SP. 2010. 397 p. Tese (Doutorado). Universidade de São Paulo, São Carlos, 2010.

FELL, R. et al. Guidelines for landslide susceptibility, hazard and risk zoning for land use planning. Engineering Geology, v.102, p.85-98, Dec. 2008.

FERREIRA, S. R. M.; VILAR, O. M. Solos não saturados no contexto geotécnico: Solos colapsíveis e expansivos. São Paulo: Associação Brasileira de Mecânica dos Solos e Engenharia Geotécnica (abms), 2015. p. 415-436.

FERREIRA, S.R.M.; FUCALE, S.T.; 1999. Características de variação de volume em solos colapsíveis do Estado de Pernambuco. In: Congresso Brasileiro de Geologia de Engenharia, 9, Anais, São Pedro.

GIARDINI, F. P.; LORANDI, R. Potencial natural de erosão na área peri-urbana de São Carlos-SP. Revista Brasileira de Cartografia, n. 56, v.01, 2004.

GONÇAlveS, A. R. L. Geologia ambiental da área de São Carlos. Tese (Doutorado em Geociências). São Paulo, 1986. Universidade de São Paulo.

GRACIOSA, M, C, P. Modelo de seguro para riscos hidrológicos com base em simulação hidráulico-hidrológica como ferramenta de gestão do risco de inundações. 2010. 191 p. Tese (Doutorado) - Curso de Hidráulica e Saneamento, Universidade de São Paulo, São Carlos, 2010.

GUIDICINI G., IWASA O.Y. (1977). Tentative correlation between rainfall and landslides in a humid tropical environment. Bulletin International Association Engineering Geology 16:13- 20.RRE

IBGE - INSTITUTO BRASILEIRO DE GEOGRAFIA E ESTATÍSTICA. Síntese das informações. Disponível em: <http://www.ibge.gov.br/cidadesat/link.php?codmun=354890>. Acesso em: Fev de 2016.

INFANTI JR, N.; FORNASSARI FILHO, N. Processos de dinâmica superficial. Livro: Geologia de Engenharia, ABGE, cap. 9, 131-152 p. 1998. 
INSTITUTO GEOGRÁFICO E CARTOGRÁFCO DO ESTADO DE SÃO PAULO. Folhas topográficas do Município de São Carlos. (São Carlos), 2012. Escala 1:10.000

IPT - Instituto de Pesquisa Tecnológica do Estado de São Paulo. Mapa Geomorfológico do Estado de São Paulo. Escala 1:500 000. Vol I. 1981a.

IPT - Instituto de Pesquisa Tecnológica do Estado de São Paulo. Mapa Geológico do Estado de São Paulo. Escala 1:500 000. Vol I. 1981b.

IPT. São Paulo. Mapeamento De Áreas De Alto E Muito Alto Risco A Deslizamentos E Inundações Do Município De São Carlos, SP.São Carlos: Centro de Tecnologias Geoambientais - Ctgeo, 2015. $146 \mathrm{p}$.

IUGS Working Group - Committee on Risk Assessment - 1997. Quantitative risk assessment for slopes and landslides - the state of the art. In: CRUDEN \& FELL (ed.), Landslide risk assessment. Proceedings of the International Workshop on Landslide Risk Assessment. A.A. Balkema. p.3-14.

LOLlO, J, A,; OLIVEIRA, C, M, G. SOLOS COLAPSÍVEIS Identificação, comportamento, impactos, riscos e soluções tecnológicas: Avaliação de Riscos em Solos Colapsíveis. São Carlos: Cultura Acadêmica, 2008. 28 p.

LOLLO, J, A;. REVISÃO DOS MÉTODOS DE CARTOGRAFIA GEOTÉCNICA DE MATERIAIS GEOLÓGICOS COLAPSÍVEIS. Revista Brasileira de Geologia de Engenharia e Ambiental, Ilha Solteira, v. 2, n. 2, p.99-116, maio 2012.

LOLLO, J. A.; ZUQUETTE, L. V. A técnica de avaliação do terreno e suas possibilidades de aplicação no mapeamento geotécnico: exemplo de um sistema de terreno identificado na região de São Carlos (SP).Geociências, v. 15, n. 1, p. 147-161, 1996.

LOLLO, J. A; RODRIGUES, R. A. Solos Colapsíveis Identificação, comportamento, impactos, riscos e soluções tecnológicas: Características dos Solos Colapsíveis. São Paulo: Cultura Acadêmica, 2008. p. 59-73.

LOLLO, J. A; SENA, J. N. Estabelecimento de suscetibilidade a erosão - diferentes técnicas para diferentes etapas de tomada de decisão. Augmdomus, La Plata, v. 5, n. 3, p.1-16, jul. 2013.

MACACARI, M. F. Variação da capacidade de carga com a sucção e profundidade em ensaios de placo em solo colapsível. 2001. 96 p. Dissertação (Mestrado). Universidade de São Paulo, São Carlos, 2001.

MACEDO, E. S.; BRESSANI, L. A. (Org.). Diretrizes para o zoneamento da suscetibilidade, perigo e risco de deslizamentos para planejamento do uso do solo. São Paulo: ABGE; ABMS, 2013. 88 p

MENDES, R.M.; LORANDI, R. 2002. Engineering geology mapping of the urban center area of São José do Rio Preto (Brazil) as an aid to urban planning. In: IAEG Conference, 9, Proceedings, Cape Town.

MILANI, E.J. Evolução tectono-estratigráfica da Bacia do Paraná e seu relacionamento com a geodinâmica fanerozóica do gondwana sul-ocidental. 1997. 255f. Tese (Doutorado). PósGraduação em Geociências, Universidade Federal do Rio Grande do Sul, Porto Alegre (RS).

MURO, M. D. Carta de zoneamento para seleção de áreas frente à instalação de aterros sanitários no município de São Carlos - SP - escala 1:50.000. 2000. 201f. Dissertação (Mestrado em Geotecnia) - Escola de Engenharia de São Carlos, Universidade de São Paulo, São Carlos, 2000. 
NEVES, M. Estudo da permeabilidade do solo colapsível da região de São Carlos. 1987. 138 p. Dissertação (Mestrado). Universidade de São Paulo, São Carlos, 1987.

NISHIYAMA, L. Mapeamento geotecnico preliminar da quadricula de São Carlos - sp. Tese (Doutorado em Geotecnia) - Escola de Engenharia de São Carlos, Universidade de São Paulo, São Carlos, 1991.

NISHIYAMA, L.; ZUQUETTE, L. V. A importância da cartografia geotécnica para caracterização de áreas de vulnerabilidade de aqüíferos livres: exemplo do aqüífero Botucatu na quadrícula de São Carlos - SP. Revista de Geociências (UNESP), São Paulo, v. 13, n.01, p. 345-357, 1994.

OLAYA, V. Sistemas de Informacion Geografica. Madrid: 2011. p. 5-30.

OLIVEIRA, C. Dicionário cartográfico. Rio de Janeiro: IBGE, 1983.

OLIVEIRA, C. H. Planejamento ambiental na Cidade de São Carlos (SP) com ênfase nas áreas públicas e áreas verdes: diagnóstico e propostas. Dissertação (Mestrado em Ecologia e Recursos Naturais). São Carlos, 1996, Universidade Federal de São Carlos.

OLIVEIRA, C.M.G.; LOLLO, J.A. 2001. Uso da Avaliação do Terreno para o zoneamento de solos colapsíveis na área urbana de Ilha Solteira (SP). In: SimpósioBrasileiro de Cartografia Geotécnica, 4, Anais, Brasília.

PARISE, M. Landslide mapping techniques and their use in the assessment of the landslide hazard. Physics and Chemistry of the Earth, Part C: Solar, Terrestrial \& Planetary Science, v.26, n.9, p.697-703, 2001.

PEJON, O, J; FERREIRA, M, D. Geotecnia Ambiental: Mapas Geotécnicos e Geoambientais. São Paulo: Elsevier, 2015. 32 p.

PINTO, C. S. Curso Básico de Mecânica dos Solos em 16 Aulas. $3^{\text {a }}$ Edição. São Paulo: Oficina de Textos, 2006. p. $345-347$

PIO, H, T. Estudo de Precipitação e Índices de Extremos Climáticos na Região de São Carlos SP. 2012. 47 p. Monografia (Especialização) - Curso de Engenharia Ambiental, Universidade de São Paulo, São Carlos, 2012.

PONS, N. A. D. Levantamento e diagnóstico geológico-geotécnico de áreas degradadas na cidade de São Carlos - SP, com auxílio de geoprocessamento. 2006. 210 p. Tese (Doutorado) - Curso de Geotecnia, Universidade de São Paulo, São Carlos, 2006.

ROLIM, G. S.; CAMARGO, M. B. P.; LANIA, D. G.; MORAES, J. L. Classificação climática de Köppen e de Thornthwaite e sua aplicabilidade na determinação de zonas Agroclimáticas para o estado de São Paulo. Bragantia, Campinas, v.66, n.4, 2007. p.711 720.

ROTTA, C, M, dos S; ZUQUETTE, L, V. Geotecnia Ambiental: Processos Erosivos. São Paulo: Elsevier, 2015. 37 p.

SAlomÃo, F, X, T.; IWASA, O, Y. Curso de Geologia Aplicada ao Meio Ambiente: Erosão e a Ocupação Rural e Urbana. São Paulo: ABGE, 1995. 25 p.

SILVA JÚNIOR, P. S.; Estudo Da Pluviometria Para Análise De Eventos Perigosos De Naureza Hidrológica E Geológica Em São Carlos - SP. 66 p. Monografia - Curso de Engenharia Ambiental, Universidade de São Paulo, São Carlos, 2016. 
SMITH, K. Enviromental Hazards: Assessing Risk And Reducing Disaster. 4. ed. New York: Routledge, 2004. 321 p.

SOARES, P.C. O Mesozóico Gondwânico no estado de São Paulo. 1973. 52 f. Tese (LivreDocência), IG/USP, São Paulo (SP).

SOBREIRA, F. G.; SOUZA, L. A. de. Cartografia geotécnica aplicada ao planejamento urbano. Revista Brasileira de Geologia de Engenharia e Ambiental, v. 2, n. 1, p. 79-97, 2012.

STAR. J; ESTES. J. Geographic Information Systems: An Introduction. Prentice-Hall, 1990.

TATIZANA, C.; OGURA, A.T.; CERRI, L.E.S.; ROCHA, M.C.M. (1987). Análise de Correlação entre Chuvas e Deslizamentos - Serra do Mar - Município de Cubatão. In: Anais do $5^{\circ}$ Congresso Brasileiro de Geologia e Engenharia, v.2, pp. 225-236, São Paulo.

TOMLIN, C. D. Geographic information systems and cartographic modelling. Prentice Hall., 1990.

TSUHA, C. H. C. Utilização de Penetrômetro Manual em Solo Colapsível e Comparação com Resultados de Provas de Carga em Placa e em Sapata. 2003. 68 f. Dissertação (Mestrado) - Curso de Geotecnia, Universidade de São Paulo, São Carlos, 2003.

TUCCI, C. E. M. Escoamento superficial. In: TUCCI, C. E. M. (Org). Hidrologia: Ciência e Aplicação. São Paulo: Editora da Universidade de São Paulo, 1993. p. 391-441.

TUCCI, Carlos E. M. Gestão de Inundações Urbanas. Porto Alegre: Ministério das Cidades Global Water Partnership - Wolrd Bank - Unesco, 2005. 269 p.

UN-ISDR - United Nations International Strategy for Disaster Reduction - Living with Risk. A Global Review of Disaster Reduction Initiatives. United Nations. Geneva, Suíça. 2004. Disponível em http://www.unisdr.org/eng/about isdr/bd-lwr-2004-eng.htm

VARNES, D.J. Slope movement types and process. Landslides - analysis and control. Transportation Research Board, Special Report 176, p.11-13, 1978.

VELOZO, R. Caracterização geológico-geotécnica do lixão desativado de São Carlos - SP, com auxílio da geofísica. 2006. 117 p. Dissertação (Mestrado). Universidade de São Paulo, São Carlos, 2006.

VEYRET, Y. 2007. Riscos: O homem como agressor e vítima do meio ambiente - São Paulo: Contexto. $1^{\text {a }}$ Edição, $1^{\text {a }}$ Reimpressão. 320 p.

VILAR, O. M.; PRANDI, E. C. . Erosão dos Solos. In: J.C.A.Cintra; J.H.Albiero. (Org.). Solos do interior de São Paulo. São Carlos-SP: ABMS, 1993, v. 1, p. 177-206.

ZUQUETTE, L. V. A importância do mapeamento geotécnico no uso e na ocupação do meio físico: fundamentos e guia para elaboração. 1993. 369p. Tese de Livre Docência, - Escola de Engenharia de São Carlos - Universidade de São Paulo, São Carlos, 1993.

ZUQUETTE, L. V. Mapeamento geotécnico preliminar na região de São Carlos. Dissertação (Mestrado em Geotecnia) - Escola de Engenharia de São Carlos, Universidade de São Paulo, São Carlos, 1981.

ZUQUETTE, L. V.; NAKAZAWA, V. A. Cartas de geologia de engenharia. São Paulo: ABGE, 1998. p. 283-30 
ANEXO A - Eventos correlacionados a índices pluviométricos 



\begin{tabular}{|c|c|c|c|c|c|}
\hline Evento & Data & Local & Fonte & $\begin{array}{c}\text { PPT em } \\
24 h(\mathbf{m m})\end{array}$ & CCM \\
\hline $\begin{array}{l}\text { Enchente/Inu } \\
\text { ndação }\end{array}$ & $22 / 02 / 1965$ & $\begin{array}{l}\text { Parte Baixa nas margens do córrego Gregório (Baixada do } \\
\text { Mercado) }\end{array}$ & A Folha & 110,1 & 1,39 \\
\hline $\begin{array}{l}\text { Enchente/Inu } \\
\text { ndação }\end{array}$ & $25 / 03 / 1965$ & $\begin{array}{l}\text { Parte Baixa nas margens do córrego Gregório (Baixada do } \\
\text { Mercado) }\end{array}$ & A Folha & 49,2 & 1,44 \\
\hline $\begin{array}{l}\text { Enchente/Inu } \\
\text { ndação }\end{array}$ & $10 / 12 / 1965$ & $\begin{array}{c}\text { Parte Baixa nas margens do córrego Gregório (Baixada do } \\
\text { Mercado) }\end{array}$ & A Folha & 13,5 & 1,21 \\
\hline $\begin{array}{c}\text { Enchente/Inu } \\
\text { ndação }\end{array}$ & $10 / 12 / 1965$ & Rua Geminiano Costa (Próximo ao mercado) & A Folha & 13,5 & 1,21 \\
\hline $\begin{array}{l}\text { Enchente/Inu } \\
\text { ndação }\end{array}$ & $17 / 11 / 1966$ & $\begin{array}{c}\text { Parte Baixa nas margens do córrego Gregório (Baixada do } \\
\text { Mercado) }\end{array}$ & A Folha & 37,8 & 1,15 \\
\hline $\begin{array}{l}\text { Enchente/Inu } \\
\text { ndação }\end{array}$ & $17 / 11 / 1966$ & Ponte da Rua José Bonifácio & A Folha & 37,8 & 1,15 \\
\hline $\begin{array}{l}\text { Enchente/Inu } \\
\text { ndação }\end{array}$ & 17/11/1966 & Rua 9 de Julho na parte baixa & A Folha & 37,8 & 1,15 \\
\hline $\begin{array}{l}\text { Enchente/Inu } \\
\text { ndação }\end{array}$ & $18 / 02 / 1967$ & Rua São Paulo & A Folha & 33,2 & 1,14 \\
\hline $\begin{array}{l}\text { Enchente/Inu } \\
\text { ndação }\end{array}$ & $18 / 02 / 1967$ & Rua Rui Barbosa. & A Folha & 33,2 & 1,14 \\
\hline $\begin{array}{l}\text { Enchente/Inu } \\
\text { ndação }\end{array}$ & $17 / 01 / 1968$ & $\begin{array}{c}\text { Parte Baixa nas margens do córrego Gregório (Baixada do } \\
\text { Mercado) }\end{array}$ & A Folha & 28,9 & 1,17 \\
\hline $\begin{array}{l}\text { Enchente/Inu } \\
\text { ndação }\end{array}$ & $17 / 01 / 1968$ & Rua São Paulo & A Folha & 28,9 & 1,17 \\
\hline $\begin{array}{c}\text { Enchente/Inu } \\
\text { ndação }\end{array}$ & $17 / 01 / 1968$ & Rua Rui Barbosa & A Folha & 28,9 & 1,17 \\
\hline $\begin{array}{c}\text { Enchente/Inu } \\
\text { ndação }\end{array}$ & $20 / 01 / 1968$ & $\begin{array}{c}\text { Parte Baixa nas margens do córrego Gregório (Baixada do } \\
\text { Mercado) }\end{array}$ & A Folha & 18,8 & 1,18 \\
\hline Alagamento & $20 / 01 / 1968$ & Rua General Osório esquina com Episcopal & A Folha & 18,8 & 1,18 \\
\hline $\begin{array}{l}\text { Enchente/Inu } \\
\text { ndação }\end{array}$ & $29 / 11 / 1968$ & $\begin{array}{c}\text { Rua Dona Alexandrina entre ruas Sete de Setembro e Major José } \\
\text { Inácio }\end{array}$ & A Folha & 23,9 & 0,77 \\
\hline $\begin{array}{l}\text { Enchente/Inu } \\
\text { ndação }\end{array}$ & 07/01/1969 & $\begin{array}{c}\text { Parte Baixa nas margens do córrego Gregório (Baixada do } \\
\text { Mercado) }\end{array}$ & A Folha & 50,8 & 0,74 \\
\hline $\begin{array}{l}\text { Enchente/Inu } \\
\text { ndação }\end{array}$ & $13 / 01 / 1970$ & Trecho entre Jesuino de Arruda e a Ponte do Gregório. & A Folha & 31,9 & 1,13 \\
\hline Alagamento & $13 / 01 / 1970$ & Rua São Paulo entre a Padre Texeira e a Treze de Maio. & A Folha & 31,9 & 1,13 \\
\hline $\begin{array}{l}\text { Enchente/Inu } \\
\text { ndação }\end{array}$ & $13 / 01 / 1970$ & Rua General Osório na baixada & A Folha & 31,9 & 1,13 \\
\hline Alagamento & $13 / 01 / 1970$ & Praça Itália & A Folha & 31,9 & 1,13 \\
\hline $\begin{array}{l}\text { Enchente/Inu } \\
\text { ndação }\end{array}$ & $15 / 01 / 1970$ & Entre Jesuino de Arruda e Geminiano Costa & A Folha & 37 & 1,17 \\
\hline $\begin{array}{l}\text { Enchente/Inu } \\
\text { ndação }\end{array}$ & $15 / 01 / 1970$ & $\begin{array}{c}\text { Parte Baixa nas margens do córrego Gregório (Baixada do } \\
\text { Mercado) }\end{array}$ & A Folha & 37 & 1,17 \\
\hline $\begin{array}{c}\text { Enchente/Inu } \\
\text { ndação }\end{array}$ & $13 / 03 / 1970$ & Rua São Paulo & A Folha & 50,8 & 1,27 \\
\hline $\begin{array}{c}\text { Enchente/Inu } \\
\text { ndação }\end{array}$ & $13 / 03 / 1970$ & $\begin{array}{c}\text { Parte Baixa nas margens do córrego Gregório (Baixada do } \\
\text { Mercado) }\end{array}$ & A Folha & 50,8 & 1,27 \\
\hline $\begin{array}{l}\text { Enchente/Inu } \\
\text { ndação }\end{array}$ & $13 / 03 / 1970$ & Confluência da General Osório com Episcopal & A Folha & 50,8 & 1,27 \\
\hline $\begin{array}{c}\text { Enchente/Inu } \\
\text { ndação }\end{array}$ & $13 / 03 / 1970$ & Geminiano Costa (Parte Baixa) & A Folha & 50,8 & 1,27 \\
\hline Alagamento & $01 / 10 / 2008$ & Avenida Getúlio Vargas & Defesa Civil & 0 & 0,65 \\
\hline $\begin{array}{l}\text { Enchente/Inu } \\
\text { ndação }\end{array}$ & $01 / 10 / 2008$ & $\begin{array}{l}\text { Rua São Joaquim Esquina com Avenida Comendador Alfredo } \\
\text { Maffei. }\end{array}$ & Defesa Civil & 0 & 0,65 \\
\hline Alagamento & $01 / 10 / 2008$ & Avenida Getúlio Vargas & Defesa Civil & 0 & 0,65 \\
\hline $\begin{array}{c}\text { Movimentos } \\
\text { de encostas }\end{array}$ & $05 / 11 / 2008$ & Serra do Cidade Aracy & Defesa Civil & 0 & 0,63 \\
\hline $\begin{array}{c}\text { Movimentos } \\
\text { de encostas }\end{array}$ & 06/02/2009 & $\begin{array}{l}\text { Queda de blocos na Avenida Integração na curva da Serra de } \\
\text { Aracy }\end{array}$ & Defesa Civil & 0 & 0,76 \\
\hline Alagamento & $30 / 03 / 2009$ & Praça Itália & Defesa Civil & 18,8 & 0,95 \\
\hline $\begin{array}{l}\text { Enchente/Inu } \\
\text { ndação }\end{array}$ & $06 / 04 / 2009$ & Avenida São Carlos proximo ao Jáu Serve & Defesa Civil & 38,2 & 0,98 \\
\hline $\begin{array}{l}\text { Enchente/Inu } \\
\text { ndação }\end{array}$ & 06/04/2009 & Avenida Francisco Pereira Lopes sentido centro/shopping & $\begin{array}{l}\text { São Carlos } \\
\text { Agora }\end{array}$ & 38,2 & 0,98 \\
\hline $\begin{array}{c}\text { Enchente/Inu } \\
\text { ndação }\end{array}$ & $12 / 10 / 2009$ & Praça do Mercado & Defesa Civil & 9,6 & 1,85 \\
\hline Alagamento & $26 / 10 / 2009$ & Rua Machado de Assis 80 & Defesa Civil & 23,2 & 1,7 \\
\hline
\end{tabular}




\begin{tabular}{|c|c|c|c|c|c|}
\hline Evento & Data & Local & Fonte & $\begin{array}{c}\text { PPT em } \\
\text { 24h (mm) }\end{array}$ & $\mathrm{CCM}$ \\
\hline Alagamento & $26 / 10 / 2009$ & Rua 26 Cidade Aracy & Defesa Civil & 23,2 & 1,7 \\
\hline Alagamento & $26 / 10 / 2009$ & Rua Rigiti Arab 267 & Defesa Civil & 23,2 & 1,7 \\
\hline Alagamento & $26 / 10 / 2009$ & Praça Itália & Defesa Civil & 23,2 & 1,7 \\
\hline Alagamento & $26 / 10 / 2009$ & $\mathrm{CDHU}$ & Defesa Civil & 23,2 & 1,7 \\
\hline $\begin{array}{c}\text { Enchente/Inu } \\
\text { ndação }\end{array}$ & $26 / 10 / 2009$ & Rotatória do Cristo & $\begin{array}{l}\text { São Carlos } \\
\text { Agora }\end{array}$ & 23,2 & 1,7 \\
\hline $\begin{array}{l}\text { Movimentos } \\
\text { de encostas }\end{array}$ & $02 / 12 / 2009$ & $\begin{array}{l}\text { Movimentos de encostas no morro da Cidade Aracy sobre a } \\
\text { Avenida da Integração, obstruindo a via pública }\end{array}$ & Defesa Civil & 1,2 & 1,57 \\
\hline $\begin{array}{c}\text { Enchente/Inu } \\
\text { ndação }\end{array}$ & $16 / 12 / 2009$ & Kartódromo & Defesa Civil & 60,6 & 1,69 \\
\hline $\begin{array}{c}\text { Enchente/Inu } \\
\text { ndação }\end{array}$ & $29 / 12 / 2009$ & Avenida Francisco Pereira Lopes & Defesa Civil & 90,4 & 1,6 \\
\hline $\begin{array}{c}\text { Enchente/Inu } \\
\text { ndação }\end{array}$ & $29 / 12 / 2009$ & Rotatória do Cristo & Defesa Civil & 90,4 & 1,6 \\
\hline Alagamento & $29 / 12 / 2009$ & Avenida Getulio Vargas 1405 & Defesa Civil & 90,4 & 1,6 \\
\hline Alagamento & $31 / 12 / 2009$ & Praça Itália & Defesa Civil & 12,6 & 1,6 \\
\hline $\begin{array}{c}\text { Enchente/Inu } \\
\text { ndação }\end{array}$ & $14 / 03 / 2010$ & Rua Conde do Pinhal - Perto da creche Anita Costa & $\begin{array}{l}\text { São Carlos } \\
\text { Agora }\end{array}$ & 66,8 & 1,38 \\
\hline $\begin{array}{c}\text { Enchente/Inu } \\
\text { ndação }\end{array}$ & $14 / 03 / 2010$ & Rotatória do Cristo & $\begin{array}{c}\text { São Carlos } \\
\text { Agora }\end{array}$ & 66,8 & 1,38 \\
\hline $\begin{array}{c}\text { Enchente/Inu } \\
\text { ndação }\end{array}$ & $14 / 03 / 2010$ & Rotátoria da Educativa na Avenida Comendador Alfredo Maffei & $\begin{array}{c}\text { São Carlos } \\
\text { Agora }\end{array}$ & 66,8 & 1,38 \\
\hline $\begin{array}{c}\text { Enchente/Inu } \\
\text { ndação }\end{array}$ & $14 / 03 / 2010$ & Baixada do Mercado & $\begin{array}{l}\text { São Carlos } \\
\text { Agora }\end{array}$ & 66,8 & 1,38 \\
\hline Alagamento & $14 / 03 / 2010$ & Praça Itália & $\begin{array}{l}\text { São Carlos } \\
\text { Agora }\end{array}$ & 66,8 & 1,38 \\
\hline $\begin{array}{c}\text { Enchente/Inu } \\
\text { ndação }\end{array}$ & 03/04/2010 & Rotatória do Cristo & $\begin{array}{l}\text { São Carlos } \\
\text { Agora }\end{array}$ & 67,6 & 1,4 \\
\hline $\begin{array}{c}\text { Enchente/Inu } \\
\text { ndação }\end{array}$ & 03/04/2010 & Baixada do Mercado & $\begin{array}{l}\text { São Carlos } \\
\text { Agora }\end{array}$ & 67,6 & 1,4 \\
\hline $\begin{array}{c}\text { Enchente/Inu } \\
\text { ndação }\end{array}$ & 03/04/2010 & Praça Itália & $\begin{array}{l}\text { São Carlos } \\
\text { Agora }\end{array}$ & 67,6 & 1,4 \\
\hline $\begin{array}{c}\text { Enchente/Inu } \\
\text { ndação }\end{array}$ & 03/04/2010 & Rotátoria da Educativa na Avenida Comendador Alfredo Maffei & $\begin{array}{l}\text { São Carlos } \\
\text { Agora }\end{array}$ & 67,6 & 1,4 \\
\hline $\begin{array}{c}\text { Enchente/Inu } \\
\text { ndação }\end{array}$ & 03/04/2010 & Comendador Alfredo Maffei, perto do Forum Civel & $\begin{array}{c}\text { São Carlos } \\
\text { Agora }\end{array}$ & 67,6 & 1,4 \\
\hline $\begin{array}{c}\text { Enchente/Inu } \\
\text { ndação }\end{array}$ & $12 / 01 / 2011$ & Rotatória do Cristo & Defesa Civil & 98,8 & 0,86 \\
\hline Alagamento & $12 / 01 / 2011$ & Rua da Paz - CDHU & Defesa Civil & 98,8 & 0,86 \\
\hline $\begin{array}{c}\text { Movimentos } \\
\text { de encostas }\end{array}$ & $12 / 01 / 2011$ & Lourenço Inocentini proximo a rodovia Washington Luiz & Defesa Civil & 98,8 & 0,86 \\
\hline $\begin{array}{c}\text { Enchente/Inu } \\
\text { ndação }\end{array}$ & $29 / 01 / 2011$ & Rotatória do Cristo & $\begin{array}{c}\text { São Carlos } \\
\text { Agora }\end{array}$ & 3 & 0,91 \\
\hline Alagamento & $29 / 01 / 2011$ & $\mathrm{CDHU}$ & $\begin{array}{c}\text { São Carlos } \\
\text { Agora }\end{array}$ & 3 & 0,91 \\
\hline Alagamento & $31 / 01 / 2011$ & Rua Natalino Sampato (antiga 26) no Bairro Cidade Aracy II & $\begin{array}{c}\text { São Carlos Dia e } \\
\text { Noite }\end{array}$ & 9 & 0,9 \\
\hline $\begin{array}{c}\text { Enchente/Inu } \\
\text { ndação }\end{array}$ & $31 / 01 / 2011$ & Rua General Osório em frente à loja Pernambucanas. & Defesa Civil & 9 & 0,9 \\
\hline $\begin{array}{c}\text { Enchente/Inu } \\
\text { ndação }\end{array}$ & $31 / 01 / 2011$ & Rua Jose Bonifacio & Defesa Civil & 9 & 0,9 \\
\hline Alagamento & $31 / 01 / 2011$ & Rua Francisco Marmorato & Defesa Civil & 9 & 0,9 \\
\hline Alagamento & $31 / 01 / 2011$ & Rua 26 Cidade Aracy & Defesa Civil & 9 & 0,9 \\
\hline Alagamento & $31 / 01 / 2011$ & Rua Icarai & Defesa Civil & 9 & 0,9 \\
\hline Alagamento & $31 / 01 / 2011$ & $\mathrm{CDHU}$ & $\begin{array}{c}\text { São Carlos } \\
\text { Agora }\end{array}$ & 9 & 0,9 \\
\hline $\begin{array}{c}\text { Movimentos } \\
\text { de encostas }\end{array}$ & $31 / 01 / 2011$ & Avenida Integração Serra da Cidade Aracy & Defesa Civil & 9 & 0,9 \\
\hline $\begin{array}{c}\text { Enchente/Inu } \\
\text { ndação }\end{array}$ & $01 / 02 / 2011$ & Rua Episcopal na Área do Mercado & $\begin{array}{c}\text { São Carlos } \\
\text { Agora }\end{array}$ & 0 & 0,9 \\
\hline $\begin{array}{c}\text { Enchente/Inu } \\
\text { ndação }\end{array}$ & $02 / 02 / 2011$ & Rotatória do Cristo & $\begin{array}{c}\text { São Carlos } \\
\text { Agora }\end{array}$ & 18,6 & 0,91 \\
\hline
\end{tabular}




\begin{tabular}{|c|c|c|c|c|c|}
\hline Evento & Data & Local & Fonte & $\begin{array}{c}\text { PPT em } \\
24 \mathrm{~h}(\mathrm{~mm})\end{array}$ & CCM \\
\hline Alagamento & $02 / 02 / 2011$ & Linha Férrea na Travessa 8 & $\begin{array}{c}\text { São Carlos } \\
\text { Agora }\end{array}$ & 18,6 & 0,91 \\
\hline Alagamento & $23 / 02 / 2011$ & Rua Reginaldo Ste Fanutte 1050 & Defesa Civil & 16,6 & 0,98 \\
\hline Alagamento & $23 / 02 / 2011$ & Avenida Getulio Vargas (Rotatória) & Defesa Civil & 16,6 & 0,98 \\
\hline Alagamento & $23 / 02 / 2011$ & Rua Desembargador Julio de Faria 1913 & Defesa Civil & 16,6 & 0,98 \\
\hline $\begin{array}{l}\text { Movimentos } \\
\text { de encostas }\end{array}$ & $23 / 02 / 2011$ & Rua 13 de maio & Defesa Civil & 16,6 & 0,98 \\
\hline $\begin{array}{l}\text { Enchente/Inu } \\
\text { ndação }\end{array}$ & $26 / 02 / 2011$ & Rotatória do Cristo & $\begin{array}{c}\text { São Carlos } \\
\text { Agora }\end{array}$ & 35,8 & 1 \\
\hline $\begin{array}{c}\text { Movimentos } \\
\text { de encostas }\end{array}$ & $28 / 02 / 2011$ & Cidade Aracy - Descida da Serra & Defesa Civil & 1,4 & 1,04 \\
\hline $\begin{array}{c}\text { Enchente/Inu } \\
\text { ndação }\end{array}$ & $12 / 03 / 2011$ & Rotatória do Cristo & $\begin{array}{c}\text { São Carlos } \\
\text { Agora }\end{array}$ & 40,2 & 1,16 \\
\hline $\begin{array}{c}\text { Enchente/Inu } \\
\text { ndação }\end{array}$ & $12 / 03 / 2011$ & Rotátoria da Educativa na Avenida Comendador Alfredo Maffei & $\begin{array}{c}\text { São Carlos } \\
\text { Agora }\end{array}$ & 40,2 & 1,16 \\
\hline $\begin{array}{c}\text { Enchente/Inu } \\
\text { ndação }\end{array}$ & $27 / 03 / 2011$ & Rotatória do Cristo & Defesa Civil & 14 & 1,11 \\
\hline $\begin{array}{c}\text { Movimentos } \\
\text { de encostas }\end{array}$ & $28 / 04 / 2011$ & Avenida Integração & Defesa Civil & 1,2 & 1,14 \\
\hline Alagamento & $07 / 12 / 2011$ & Praça Itália & Defesa Civil & 0 & 0,8 \\
\hline $\begin{array}{l}\text { Movimentos } \\
\text { de encostas }\end{array}$ & $07 / 12 / 2011$ & Serra de Aracy & Defesa Civil & 0 & 0,8 \\
\hline $\begin{array}{l}\text { Enchente/Inu } \\
\text { ndação }\end{array}$ & $31 / 12 / 2011$ & Rotatória do Cristo & $\begin{array}{c}\text { São Carlos } \\
\text { Agora }\end{array}$ & 59 & 0,87 \\
\hline $\begin{array}{c}\text { Enchente/Inu } \\
\text { ndação }\end{array}$ & $31 / 12 / 2011$ & Avenida Francisco Pereira Lopes & Defesa Civil & 59 & 0,87 \\
\hline Alagamento & $31 / 12 / 2011$ & $\mathrm{CDHU}$ & Defesa Civil & 59 & 0,87 \\
\hline $\begin{array}{c}\text { Movimentos } \\
\text { de encostas }\end{array}$ & $31 / 12 / 2011$ & Avenida Integração & Defesa Civil & 59 & 0,87 \\
\hline Alagamento & $31 / 12 / 2011$ & Praça Itália & $\begin{array}{c}\text { São Carlos } \\
\text { Agora }\end{array}$ & 59 & 0,87 \\
\hline $\begin{array}{c}\text { Enchente/Inu } \\
\text { ndação }\end{array}$ & $03 / 11 / 2012$ & Rotatória do Cristo & $\begin{array}{c}\text { São Carlos } \\
\text { Agora }\end{array}$ & 39,4 & 1,5 \\
\hline Alagamento & $05 / 11 / 2012$ & $\mathrm{CDHU}$ & Defesa Civil & 0 & 1,45 \\
\hline Alagamento & $05 / 11 / 2012$ & Praça Itália & Defesa Civil & 0 & 1,45 \\
\hline Alagamento & $25 / 11 / 2012$ & Rua Bento Carlos 1498 & Defesa Civil & 39 & 1,39 \\
\hline Alagamento & $25 / 11 / 2012$ & Avenida Capitão Luiz Brandão 1677 & Defesa Civil & 39 & 1,39 \\
\hline $\begin{array}{c}\text { Enchente/Inu } \\
\text { ndação }\end{array}$ & $09 / 12 / 2012$ & Rotatória do Cristo & Defesa Civil & 57,2 & 1,31 \\
\hline $\begin{array}{c}\text { Enchente/Inu } \\
\text { ndação }\end{array}$ & $09 / 12 / 2012$ & Tancredo Neves Rotatória Engefort & Defesa Civil & 57,2 & 1,31 \\
\hline $\begin{array}{c}\text { Enchente/Inu } \\
\text { ndação }\end{array}$ & $09 / 12 / 2012$ & Kartódromo & $\begin{array}{c}\text { São Carlos } \\
\text { Agora }\end{array}$ & 57,2 & 1,31 \\
\hline $\begin{array}{c}\text { Enchente/Inu } \\
\text { ndação }\end{array}$ & $09 / 12 / 2012$ & Avenida Eliza Gonzales Rabello & $\begin{array}{c}\text { São Carlos } \\
\text { Agora }\end{array}$ & 57,2 & 1,31 \\
\hline $\begin{array}{l}\text { Enchente/Inu } \\
\text { ndação }\end{array}$ & $09 / 12 / 2012$ & $\begin{array}{c}\text { Avenida Francisco Pereira Lopes, na região do Restaurante Casa } \\
\text { Branca }\end{array}$ & $\begin{array}{l}\text { São Carlos } \\
\text { Agora }\end{array}$ & 57,2 & 1,31 \\
\hline $\begin{array}{l}\text { Enchente/Inu } \\
\text { ndação }\end{array}$ & $12 / 01 / 2013$ & Rotatória do Cristo & $\begin{array}{l}\text { São Carlos } \\
\text { Agora }\end{array}$ & 95,4 & 1,27 \\
\hline $\begin{array}{l}\text { Enchente/Inu } \\
\text { ndação }\end{array}$ & $12 / 01 / 2013$ & Kartódromo & $\begin{array}{l}\text { São Carlos } \\
\text { Agora }\end{array}$ & 95,4 & 1,27 \\
\hline $\begin{array}{c}\text { Enchente/Inu } \\
\text { ndação }\end{array}$ & $22 / 02 / 2013$ & Kartódromo & $\begin{array}{l}\text { São Carlos } \\
\text { Agora }\end{array}$ & 70,4 & 1,15 \\
\hline $\begin{array}{c}\text { Enchente/Inu } \\
\text { ndação }\end{array}$ & $22 / 02 / 2013$ & Rotatória do Cristo & Região Destake & 70,4 & 1,15 \\
\hline $\begin{array}{c}\text { Enchente/Inu } \\
\text { ndação }\end{array}$ & $22 / 02 / 2013$ & $\begin{array}{c}\text { Cruzamento da Avenida Comendador Alfredo Maffei com a Rua } \\
\text { Dom Pedro II }\end{array}$ & Região Destake & 70,4 & 1,15 \\
\hline $\begin{array}{c}\text { Enchente/Inu } \\
\text { ndação }\end{array}$ & $22 / 02 / 2013$ & $\begin{array}{c}\text { Trabalhador São Carlense com Francisco Pereira Lopes próximo a } \\
\text { Usp }\end{array}$ & Região Destake & 70,4 & 1,15 \\
\hline Alagamento & $22 / 02 / 2013$ & $\mathrm{CDHU}$ & Região Destake & 70,4 & 1,15 \\
\hline Alagamento & $25 / 02 / 2013$ & Praça Itália & $\begin{array}{l}\text { São Carlos Dia e } \\
\text { Noite }\end{array}$ & 0 & 1,15 \\
\hline
\end{tabular}




\begin{tabular}{|c|c|c|c|c|c|}
\hline Evento & Data & Local & Fonte & $\begin{array}{c}\text { PPT em } \\
\text { 24h (mm) }\end{array}$ & CCM \\
\hline Alagamento & $25 / 02 / 2013$ & CDHU & $\begin{array}{c}\text { São Carlos Dia e } \\
\text { Noite }\end{array}$ & 0 & 1,15 \\
\hline Alagamento & $25 / 02 / 2013$ & Avenida Getúlio Vargas próximo a empresa Latina & $\begin{array}{c}\text { São Carlos Dia e } \\
\text { Noite }\end{array}$ & 0 & 1,15 \\
\hline $\begin{array}{c}\text { Enchente/Inu } \\
\text { ndação }\end{array}$ & $28 / 02 / 2013$ & Rotátoria da Educativa na Avenida Comendador Alfredo Maffei & $\begin{array}{c}\text { São Carlos } \\
\text { Agora } \\
\end{array}$ & 26,8 & 1,15 \\
\hline Alagamento & 09/03/2013 & Avenida Getúlio Vargas & Região Destake & 31 & 1,14 \\
\hline Alagamento & 09/03/2013 & Praça Itália & Região Destake & 31 & 1,14 \\
\hline $\begin{array}{c}\text { Enchente/Inu } \\
\text { ndação }\end{array}$ & $25 / 03 / 2013$ & Regiao da Baixada do Mercado (Rua Episcopal ) & Primeira Página & 16,8 & 1,18 \\
\hline Alagamento & $25 / 03 / 2013$ & Avenida Getúlio Vargas próximo a empresa Latina & Primeira Página & 16,8 & 1,18 \\
\hline $\begin{array}{c}\text { Enchente/Inu } \\
\text { ndaçã̃o }\end{array}$ & $25 / 03 / 2013$ & Baixada do Mercado (Avenida Comendador Alfredo Maffei) & Primeira Página & 16,8 & 1,18 \\
\hline Alagamento & $25 / 03 / 2013$ & Praça Itália & $\begin{array}{c}\text { São Carlos } \\
\text { Agora }\end{array}$ & 16,8 & 1,18 \\
\hline $\begin{array}{c}\text { Enchente/Inu } \\
\text { ndação }\end{array}$ & $25 / 03 / 2013$ & Rotatória do Cristo & $\begin{array}{c}\text { São Carlos } \\
\text { Agora }\end{array}$ & 16,8 & 1,18 \\
\hline Alagamento & $25 / 03 / 2013$ & $\mathrm{CDHU}$ & $\begin{array}{c}\text { São Carlos } \\
\text { Agora }\end{array}$ & 16,8 & 1,18 \\
\hline Alagamento & 03/04/2013 & $\mathrm{CDHU}$ & $\begin{array}{c}\text { São Carlos } \\
\text { Agora }\end{array}$ & 0,4 & 1,17 \\
\hline Alagamento & 03/04/2013 & Praça Itália & $\begin{array}{c}\text { São Carlos } \\
\text { Agora }\end{array}$ & 0,4 & 1,17 \\
\hline Alagamento & $03 / 04 / 2013$ & Pontilhao da Travessa 8 & $\begin{array}{c}\text { São Carlos } \\
\text { Agora }\end{array}$ & 0,4 & 1,17 \\
\hline Alagamento & 03/04/2013 & Avenida Getúlio Vargas próximo a empresa Latina & $\begin{array}{c}\text { São Carlos } \\
\text { Agora }\end{array}$ & 0,4 & 1,17 \\
\hline Alagamento & 03/04/2013 & Rotatória do posto de combustíveis do Maria Stella Faga & $\begin{array}{c}\text { São Carlos } \\
\text { Agora }\end{array}$ & 0,4 & 1,17 \\
\hline $\begin{array}{c}\text { Enchente/Inu } \\
\text { ndação }\end{array}$ & 03/04/2013 & Rotátoria da Educativa na Avenida Comendador Alfredo Maffei & $\begin{array}{c}\text { São Carlos } \\
\text { Agora }\end{array}$ & 0,4 & 1,17 \\
\hline Alagamento & $28 / 05 / 2013$ & Rua Coronel Leopoldo Prado, linha ferrea & $\begin{array}{c}\text { São Carlos Dia e } \\
\text { Noite } \\
\end{array}$ & 62 & 1,17 \\
\hline Alagamento & $29 / 05 / 2013$ & $\mathrm{CDHU}$ & $\begin{array}{c}\text { São Carlos } \\
\text { Agora }\end{array}$ & 56 & 1,21 \\
\hline $\begin{array}{c}\text { Enchente/Inu } \\
\text { ndação }\end{array}$ & $22 / 10 / 2013$ & Rotatória do Cristo & EPTV & 46,2 & 1,38 \\
\hline $\begin{array}{l}\text { Enchente/Inu } \\
\text { ndação }\end{array}$ & $22 / 10 / 2013$ & Baixada do Mercado & EPTV & 46,2 & 1,38 \\
\hline $\begin{array}{c}\text { Enchente/Inu } \\
\text { ndação }\end{array}$ & $22 / 10 / 2013$ & Avenida Comendador Alfredo Maffei & EPTV & 46,2 & 1,38 \\
\hline Alagamento & $22 / 10 / 2013$ & $\mathrm{CDHU}$ & EPTV & 46,2 & 1,38 \\
\hline $\begin{array}{c}\text { Enchente/Inu } \\
\text { ndação }\end{array}$ & $22 / 10 / 2013$ & Rotátoria da Educativa na Avenida Comendador Alfredo Maffei & $\begin{array}{c}\text { São Carlos } \\
\text { Agora }\end{array}$ & 46,2 & 1,38 \\
\hline $\begin{array}{c}\text { Enchente/Inu } \\
\text { ndação }\end{array}$ & $04 / 11 / 2013$ & Rotatória do Cristo & $\begin{array}{c}\text { São Carlos } \\
\text { Agora }\end{array}$ & 49,6 & 1,33 \\
\hline $\begin{array}{c}\text { Enchente/Inu } \\
\text { ndação }\end{array}$ & $04 / 11 / 2013$ & Rotátoria entre as ruas Jose Bonifácio e Jesuíno de Arruda & $\begin{array}{c}\text { São Carlos } \\
\text { Agora }\end{array}$ & 49,6 & 1,33 \\
\hline $\begin{array}{c}\text { Enchente/Inu } \\
\text { ndação }\end{array}$ & $31 / 12 / 2013$ & Rotatória do Cristo & $\begin{array}{c}\text { São Carlos } \\
\text { Agora }\end{array}$ & 38,8 & 0,93 \\
\hline $\begin{array}{c}\text { Enchente/Inu } \\
\text { ndação }\end{array}$ & $28 / 12 / 2014$ & Cidade Aracy & $\begin{array}{c}\text { São Carlos Dia e } \\
\text { Noite }\end{array}$ & 1,6 & 0,87 \\
\hline $\begin{array}{l}\text { Enchente/Inu } \\
\text { ndação }\end{array}$ & $23 / 01 / 2015$ & Cidade Aracy II & Primeira Pagina & 0,2 & 0,75 \\
\hline $\begin{array}{c}\text { Enchente/Inu } \\
\text { ndação }\end{array}$ & $25 / 02 / 2015$ & Rotatória do Cristo & Região Destake & 35,8 & 0,78 \\
\hline $\begin{array}{l}\text { Enchente/Inu } \\
\text { ndação }\end{array}$ & $27 / 02 / 2015$ & Avenida São Carlos na região do União Serv. & $\begin{array}{c}\text { São Carlos Dia e } \\
\text { Noite }\end{array}$ & 10 & 0,78 \\
\hline $\begin{array}{c}\text { Enchente/Inu } \\
\text { ndação }\end{array}$ & $11 / 03 / 2015$ & Avenida São Carlos na região do União Serv. & Primeira Página & 9,6 & 0,78 \\
\hline $\begin{array}{c}\text { Enchente/Inu } \\
\text { ndação }\end{array}$ & $11 / 03 / 2015$ & $\begin{array}{c}\text { Cruzamento das Avenidas Liberdade e Elisa Gonzales Rabelo } \\
\text { (Parque do Kartodromo) }\end{array}$ & Primeira Página & 9,6 & 0,78 \\
\hline $\begin{array}{l}\text { Enchente/Inu } \\
\text { ndação }\end{array}$ & $16 / 03 / 2015$ & Calçadão da General Osório (Baxada do Mercado) & $\begin{array}{l}\text { São Carlos } \\
\text { Agora }\end{array}$ & 13,2 & 0,79 \\
\hline $\begin{array}{c}\text { Enchente/Inu } \\
\text { ndação }\end{array}$ & $28 / 03 / 2015$ & Kartódromo & Primeira Página & 15 & 0,84 \\
\hline $\begin{array}{l}\text { Enchente/Inu } \\
\text { ndação }\end{array}$ & $28 / 03 / 2015$ & Rotatória do Cristo & Primeira Página & 15 & 0,84 \\
\hline
\end{tabular}




\begin{tabular}{|c|c|c|c|c|c|}
\hline Evento & Data & Local & Fonte & $\begin{array}{c}\text { PPT em } \\
24 h(\mathbf{m m})\end{array}$ & CCM \\
\hline Alagamento & 05/06/2015 & Benjamim Lopes Osores, no condomínio Tecumseh Village & $\begin{array}{l}\text { São Carlos Dia e } \\
\text { Noite }\end{array}$ & 0,2 & 0,22 \\
\hline Alagamento & $08 / 09 / 2015$ & Rua João Martins França na Cidade Aracy & Primeira Página & 46,6 & 1,23 \\
\hline Alagamento & $04 / 11 / 2015$ & Rua João Martins França, Cidade Aracy 2 & $\begin{array}{l}\text { São Carlos } \\
\text { Agora }\end{array}$ & 2,6 & 1,27 \\
\hline Alagamento & $04 / 11 / 2015$ & Rua santa Gertrudes (sentido rotatória do CDHU) & Primeira Página & 2,6 & 1,27 \\
\hline Alagamento & $04 / 11 / 2015$ & Rua João Martins França na Cidade Aracy & Primeira Página & 2,6 & 1,27 \\
\hline Alagamento & $04 / 11 / 2015$ & $\mathrm{CDHU}$ & Primeira Página & 2,6 & 1,27 \\
\hline Alagamento & $17 / 11 / 2015$ & Rua santa Gertrudes (sentido rotatória do CDHU) & $\begin{array}{l}\text { São Carlos Dia e } \\
\text { Noite }\end{array}$ & 6,4 & 1,18 \\
\hline $\begin{array}{l}\text { Enchente/Inu } \\
\text { ndação }\end{array}$ & $23 / 11 / 2015$ & Avenida Trabalhador São Carlense & Primeira Página & 37,2 & 1,3 \\
\hline $\begin{array}{c}\text { Enchente/Inu } \\
\text { ndação }\end{array}$ & $23 / 11 / 2015$ & $\begin{array}{c}\text { Baixada do Mercado (9 de Julho com Comendador Alfredo } \\
\text { Maffei) }\end{array}$ & Primeira Página & 37,2 & 1,3 \\
\hline $\begin{array}{c}\text { Enchente/Inu } \\
\text { ndação }\end{array}$ & $23 / 11 / 2015$ & Baixada do Mercado ( Geminiado Costa com Episcopal) & Primeira Página & 37,2 & 1,3 \\
\hline $\begin{array}{c}\text { Enchente/Inu } \\
\text { ndação }\end{array}$ & $23 / 11 / 2015$ & $\begin{array}{c}\text { Baixada do Mercado (Comendador Alfredo Maffei com } \\
\text { Geminiano Costa) }\end{array}$ & Primeira Página & 37,2 & 1,3 \\
\hline Alagamento & $23 / 11 / 2015$ & Praça Itália & Primeira Página & 37,2 & 1,3 \\
\hline Alagamento & $23 / 11 / 2015$ & Rua Raimundo Correa & Primeira Página & 37,2 & 1,3 \\
\hline $\begin{array}{c}\text { Enchente/Inu } \\
\text { ndação }\end{array}$ & $23 / 11 / 2015$ & Rotatória do Cristo & Primeira Página & 37,2 & 1,3 \\
\hline $\begin{array}{c}\text { Enchente/Inu } \\
\text { ndação }\end{array}$ & $23 / 11 / 2015$ & Kartódromo & Primeira Página & 37,2 & 1,3 \\
\hline $\begin{array}{l}\text { Enchente/Inu } \\
\text { ndação }\end{array}$ & $23 / 11 / 2015$ & Região da Rodoviária & Primeira Página & 37,2 & 1,3 \\
\hline $\begin{array}{c}\text { Enchente/Inu } \\
\text { ndação }\end{array}$ & $23 / 11 / 2015$ & Rua Dona Alexandrina & A Folha & 37,2 & 1,3 \\
\hline $\begin{array}{c}\text { Enchente/Inu } \\
\text { ndação }\end{array}$ & $23 / 11 / 2015$ & Rua São Joaquim & A Folha & 37,2 & 1,3 \\
\hline $\begin{array}{c}\text { Enchente/Inu } \\
\text { ndação }\end{array}$ & $23 / 11 / 2015$ & Parque do Bicão & A Folha & 37,2 & 1,3 \\
\hline Alagamento & $23 / 11 / 2015$ & $\mathrm{CDHU}$ & $\begin{array}{l}\text { Revelando São } \\
\text { Carlos }\end{array}$ & 37,2 & 1,3 \\
\hline $\begin{array}{c}\text { Enchente/Inu } \\
\text { ndação }\end{array}$ & $23 / 11 / 2015$ & $\begin{array}{c}\text { Avenida Francisco Pereira Lopes, na região do Restaurante Casa } \\
\text { Branca }\end{array}$ & $\begin{array}{l}\text { Revelando São } \\
\text { Carlos }\end{array}$ & 37,2 & 1,3 \\
\hline Alagamento & $10 / 12 / 2015$ & Rua João Martins França na Cidade Aracy & $\begin{array}{l}\text { São Carlos Em } \\
\text { Rede }\end{array}$ & 10,4 & 1,18 \\
\hline Alagamento & $10 / 12 / 2015$ & Rua Raimundo Correia & EPTV & 10,4 & 1,18 \\
\hline Alagamento & $10 / 01 / 2016$ & Rua santa Gertrudes (sentido rotatória do CDHU) & $\begin{array}{l}\text { São Carlos Em } \\
\text { Rede }\end{array}$ & 23,2 & 1,09 \\
\hline $\begin{array}{c}\text { Enchente/Inu } \\
\text { ndação }\end{array}$ & $10 / 01 / 2016$ & Rotátoria da Educativa na Avenida Comendador Alfredo Maffei & $\begin{array}{l}\text { São Carlos Em } \\
\text { Rede }\end{array}$ & 23,2 & 1,09 \\
\hline $\begin{array}{c}\text { Enchente/Inu } \\
\text { ndação }\end{array}$ & $12 / 01 / 2016$ & Rotatória do Cristo & Região Destake & 130,6 & 1,26 \\
\hline $\begin{array}{c}\text { Enchente/Inu } \\
\text { ndação }\end{array}$ & $13 / 01 / 2016$ & Parque Ecologico & $\begin{array}{l}\text { Revelando São } \\
\text { Carlos }\end{array}$ & 21,2 & 1,27 \\
\hline $\begin{array}{c}\text { Enchente/Inu } \\
\text { ndação }\end{array}$ & $25 / 01 / 2016$ & Parque do Bicão & $\begin{array}{l}\text { São Carlos } \\
\text { Agora }\end{array}$ & 15,6 & 1,27 \\
\hline Alagamento & $25 / 01 / 2016$ & Rua Jose Bonifacio proximo a antiga Fabber & $\begin{array}{l}\text { São Carlos } \\
\text { Agora }\end{array}$ & 15,6 & 1,27 \\
\hline $\begin{array}{c}\text { Enchente/Inu } \\
\text { ndação }\end{array}$ & $25 / 01 / 2016$ & Rotatória do Cristo & $\begin{array}{l}\text { São Carlos } \\
\text { Agora }\end{array}$ & 15,6 & 1,27 \\
\hline Alagamento & $18 / 02 / 2016$ & Bairro Lagoa Serena & $\begin{array}{l}\text { São Carlos Em } \\
\text { Rede }\end{array}$ & 14,6 & 1,19 \\
\hline Alagamento & $18 / 02 / 2016$ & Praça Itália & $\begin{array}{l}\text { São Carlos Em } \\
\text { Rede }\end{array}$ & 14,6 & 1,19 \\
\hline $\begin{array}{c}\text { Movimentos } \\
\text { de encostas }\end{array}$ & $13 / 03 / 2016$ & $\begin{array}{c}\text { Escorregamento em uma passagem que interliga Cidade Aracy } 2 \mathrm{e} \\
\text { a Avenida Integração }\end{array}$ & $\begin{array}{l}\text { São Carlos } \\
\text { Agora }\end{array}$ & 0 & 1,13 \\
\hline $\begin{array}{c}\text { Enchente/Inu } \\
\text { ndação }\end{array}$ & $16 / 05 / 2016$ & $\begin{array}{c}\text { Avenida Francisco Pereira Lopes, na região do Restaurante Casa } \\
\text { Branca }\end{array}$ & $\begin{array}{l}\text { São Carlos Em } \\
\text { Rede }\end{array}$ & 51,2 & 1,03 \\
\hline $\begin{array}{l}\text { Enchente/Inu } \\
\text { ndação }\end{array}$ & $19 / 01 / 1965$ & $\begin{array}{c}\text { Parte Baixa nas margens do córrego Gregório (Baixada do } \\
\text { Mercado) }\end{array}$ & A Folha & 76,6 & 1,4 \\
\hline
\end{tabular}



APÊNDICE A - Eventos históricos registrados 



\begin{tabular}{|c|c|c|c|c|c|}
\hline \multirow{2}{*}{ Data } & \multirow{2}{*}{ Eventos } & \multirow{2}{*}{ Local } & \multirow{2}{*}{ Fonte } & \multicolumn{2}{|c|}{ CA23S } \\
\hline & & & & $\mathbf{X}$ & $\mathbf{Y}$ \\
\hline $19 / 01 / 1965$ & Enchente/Inundação & $\begin{array}{c}\text { Parte baixa nas margens do córrego Gregório (Baixada } \\
\text { do Mercado) }\end{array}$ & A Folha & 201551 & 7562083 \\
\hline $22 / 02 / 1965$ & Enchente/Inundação & $\begin{array}{c}\begin{array}{c}\text { Parte baixa nas margens do córrego Gregório (Baixada } \\
\text { do Mercado) }\end{array} \\
\end{array}$ & A Folha & 201551 & 7562083 \\
\hline 25/03/1965 & Enchente/Inundação & $\begin{array}{c}\text { Parte baixa nas margens do córrego Gregório (Baixada } \\
\text { do Mercado) }\end{array}$ & A Folha & 201551 & 7562083 \\
\hline $10 / 12 / 1965$ & Enchente/Inundação & $\begin{array}{l}\text { Parte baixa nas margens do córrego Gregório (Baixada } \\
\text { do Mercado) }\end{array}$ & A Folha & 201551 & 7562083 \\
\hline $10 / 12 / 1965$ & Enchente/Inundação & Rua Geminiano Costa (Próximo ao mercado) & A Folha & 201552 & 7562066 \\
\hline $17 / 11 / 1966$ & Enchente/Inundação & $\begin{array}{c}\text { Parte baixa nas margens do córrego Gregório (Baixada } \\
\text { do Mercado) }\end{array}$ & A Folha & 201551 & 7562083 \\
\hline 17/11/1966 & Enchente/Inundação & Ponte da Rua José Bonifácio & A Folha & 201288 & 7562165 \\
\hline $17 / 11 / 1966$ & Enchente/Inundação & $\begin{array}{c}\text { Rua } 9 \text { de Julho na parte baixa, no cruzamento com a } \\
\text { Geminiano Costa }\end{array}$ & A Folha & 201399 & 7562056 \\
\hline $18 / 02 / 1967$ & Enchente/Inundação & Rua São Paulo & A Folha & 202116 & 7562052 \\
\hline $18 / 02 / 1967$ & Enchente/Inundação & Rua Rui Barbosa. & A Folha & 202012 & 7562068 \\
\hline 17/01/1968 & Enchente/Inundação & $\begin{array}{c}\text { Parte baixa nas margens do córrego Gregório (Baixada } \\
\text { do Mercado) }\end{array}$ & A Folha & 201551 & 7562083 \\
\hline 17/01/1968 & Enchente/Inundação & Rua São Paulo & A Folha & 202116 & 7562052 \\
\hline $17 / 01 / 1968$ & Enchente/Inundação & Rua Rui Barbosa & A Folha & 202012 & 7562068 \\
\hline 20/01/1968 & Enchente/Inundação & $\begin{array}{c}\text { Parte baixa nas margens do córrego Gregório (Baixada } \\
\text { do Mercado) }\end{array}$ & A Folha & 201551 & 7562083 \\
\hline $20 / 01 / 1968$ & Enchente/Inundação & Rua General Osório esquina com Episcopal & A Folha & 201504 & 7561959 \\
\hline 29/11/1968 & Alagamento & $\begin{array}{l}\text { Rua Dona Alexandrina entre ruas Sete de Setembro e } \\
\text { Major José Inácio }\end{array}$ & A Folha & 201692 & 7562528 \\
\hline 07/01/1969 & Enchente/Inundação & $\begin{array}{c}\text { Parte baixa nas margens do córrego Gregório (Baixada } \\
\text { do Mercado) }\end{array}$ & A Folha & 201551 & 7562083 \\
\hline 13/01/1970 & Enchente/Inundação & Trecho entre Jesuino de Arruda e a Ponte do Gregório. & A Folha & 201288 & 7562165 \\
\hline 13/01/1970 & Alagamento & Rua São Paulo entre a Padre Teixeira e a Treze de Maio. & A Folha & 202104 & 7562501 \\
\hline 13/01/1970 & Enchente/Inundação & Rua General Osório na baixada & A Folha & 201558 & 7561962 \\
\hline $13 / 01 / 1970$ & Alagamento & Praça Itália & A Folha & 201636 & 7560747 \\
\hline $15 / 01 / 1970$ & Enchente/Inundação & Entre Jesuino de Arruda e Geminiano Costa & A Folha & 201500 & 7562089 \\
\hline $15 / 01 / 1970$ & Enchente/Inundação & $\begin{array}{c}\text { Parte baixa nas margens do córrego Gregório (Baixada } \\
\text { do Mercado) }\end{array}$ & A Folha & 201551 & 7562083 \\
\hline 13/03/1970 & Enchente/Inundação & Rua São Paulo & A Folha & 202116 & 7562052 \\
\hline $13 / 03 / 1970$ & Enchente/Inundação & $\begin{array}{c}\text { Parte baixa nas margens do córrego Gregório (Baixada } \\
\text { do Mercado) }\end{array}$ & A Folha & 201551 & 7562083 \\
\hline 13/03/1970 & Enchente/Inundação & Confluência da General Osório com Episcopal & A Folha & 201504 & 7561959 \\
\hline $13 / 03 / 1970$ & Enchente/Inundação & Geminiano Costa (Parte Baixa) & A Folha & 201552 & 7562066 \\
\hline $13 / 03 / 1970$ & Erosão & Ponte da Rua São Paulo que cruza o Gregório & A Folha & 202116 & 7562052 \\
\hline $23 / 02 / 1972$ & Enchente/Inundação & Praça do Mercado toda inundada & A Folha & 201551 & 7562083 \\
\hline 23/02/1972 & Enchente/Inundação & Rua Santa Cruz (Baixada da Cidade) & A Folha & 201567 & 7561756 \\
\hline $23 / 02 / 1972$ & Enchente/Inundação & Rua General Osório (Baixada da Cidade) & A Folha & 201558 & 7561962 \\
\hline 23/02/1972 & Enchente/Inundação & Geminiano Costa (Baixada do Mercado) & A Folha & 201552 & 7562066 \\
\hline 23/02/1972 & Enchente/Inundação & Rua Episcopal (Baixada do Mercado) & A Folha & 201500 & 7562089 \\
\hline 10/10/1972 & Enchente/Inundação & Geminiano Costa com Episcopal & A Folha & 201499 & 7562061 \\
\hline 10/10/1972 & Enchente/Inundação & General Osório com Episcopal & A Folha & 201504 & 7561959 \\
\hline 04/02/1973 & Alagamento & Treze de Maio com Rui Barbosa & A Folha & 202006 & 7562286 \\
\hline $04 / 02 / 1973$ & Enchente/Inundação & $\begin{array}{c}\text { Parte baixa nas margens do córrego Gregório (Baixada } \\
\text { do Mercado) }\end{array}$ & A Folha & 201551 & 7562083 \\
\hline 04/02/1973 & Enchente/Inundação & Rua Episcopal cruzamento com a Santa Cruz & A Folha & 201512 & 7561755 \\
\hline 04/02/1973 & Alagamento & Rua Visconde de Inhaúma por volta do n 926 & A Folha & 200966 & 7562580 \\
\hline $19 / 12 / 1973$ & Alagamento & Bairro Lagoa Serena & A Folha & 201442 & 7561418 \\
\hline $01 / 12 / 1976$ & Enchente/Inundação & Rua Riachuelo (Baixada da Cidade) & A Tribuna & 201080 & 7562366 \\
\hline
\end{tabular}




\begin{tabular}{|c|c|c|c|c|c|}
\hline \multirow{2}{*}{ Data } & \multirow{2}{*}{ Eventos } & \multirow{2}{*}{ Local } & \multirow{2}{*}{ Fonte } & \multicolumn{2}{|c|}{ CA23S } \\
\hline & & & & $\mathbf{X}$ & $\mathbf{Y}$ \\
\hline 21/03/1977 & Alagamento & Bairro Lagoa Serena & A Folha & 201442 & 7561418 \\
\hline 21/03/1977 & Enchente/Inundação & Baixada do Mercado & A Folha & 201551 & 7562083 \\
\hline 21/03/1977 & Enchente/Inundação & Rua General Osório (Baixada da Cidade) & A Folha & 201504 & 7561959 \\
\hline 21/03/1977 & Enchente/Inundação & Episcopal entre Geminiano Costa e General Osório. & A Folha & 201501 & 7562011 \\
\hline 21/03/1977 & Alagamento & Rua Francisco Marmorato & A Folha & 201458 & 7561113 \\
\hline 21/03/1977 & Alagamento & Rua Machado de Assis & A Folha & 201592 & 7561017 \\
\hline 05/10/1977 & Enchente/Inundação & Rua Episcopal na área do Mercado & A Folha & 201500 & 7562089 \\
\hline 09/01/1978 & Enchente/Inundação & Baixada do Mercado & A Folha & 201551 & 7562083 \\
\hline 06/03/1979 & Erosão & Rua Marcolino Pelicano perto do Senai & A Folha & 200984 & 7561775 \\
\hline 27/01/1987 & Enchente/Inundação & Toda a baixada do Mercado & A Folha & 201551 & 7562083 \\
\hline $10 / 01 / 1988$ & Enchente/Inundação & Baixada do mercado, no calçadão da General Osório & A Folha & 201558 & 7561962 \\
\hline $31 / 12 / 1989$ & Enchente/Inundação & Baixada do Mercado & A Folha & 201551 & 7562083 \\
\hline 06/03/1990 & Enchente/Inundação & Baixada do Mercado & A Folha & 201551 & 7562083 \\
\hline $06 / 03 / 1990$ & Alagamento & Praça Itália & A Folha & 201636 & 7560747 \\
\hline 17/10/1991 & Enchente/Inundação & Baixada do mercado, no calçadão da General Osório & A Folha & 201558 & 7561962 \\
\hline $16 / 02 / 1993$ & Enchente/Inundação & Rotatória do Cristo & A Folha & 199373 & 7562411 \\
\hline $16 / 02 / 1993$ & Enchente/Inundação & Baixada do Mercado & A Folha & 201551 & 7562083 \\
\hline $16 / 02 / 1993$ & Enchente/Inundação & Avenida Liberdade no Santa Paula, & A Folha & 200600 & 7564344 \\
\hline $16 / 02 / 1993$ & Enchente/Inundação & Rua São Paulo com Geminiano Costa & A Folha & 202113 & 7562089 \\
\hline $16 / 02 / 1993$ & Enchente/Inundação & Rua São Paulo com Geminiano Costa & A Folha & 202116 & 7562052 \\
\hline $19 / 02 / 1993$ & Enchente/Inundação & Baixada do Mercado & A Folha & 201551 & 7562083 \\
\hline $16 / 05 / 1995$ & Enchente/Inundação & Avenida Comendador Alfredo Maffei & A Folha & 201448 & 7562098 \\
\hline $16 / 05 / 1995$ & Enchente/Inundação & Rua Episcopal (Baixada do Mercado) & A Folha & 201499 & 7562061 \\
\hline $16 / 05 / 1995$ & Enchente/Inundação & Rua Geminiano Costa (Baixada do Mercado) & A Folha & 201552 & 7562066 \\
\hline $16 / 05 / 1995$ & Enchente/Inundação & Baixada do Mercado & A Folha & 201551 & 7562083 \\
\hline 05/06/1997 & Enchente/Inundação & Baixada do Mercado & A noticia local & 201551 & 7562083 \\
\hline 05/06/1997 & Enchente/Inundação & Rotatória do Cristo & A noticia local & 199373 & 7562411 \\
\hline 24/12/1997 & Enchente/Inundação & Rotatória do Cristo & A Folha & 199373 & 7562411 \\
\hline 28/01/1998 & Enchente/Inundação & Rotatória do Cristo & A Folha & 199373 & 7562411 \\
\hline 28/01/1998 & Enchente/Inundação & Kartódromo & A Folha & 200600 & 7564344 \\
\hline 20/02/1998 & Enchente/Inundação & Baixada do Mercado & A Folha & 201551 & 7562083 \\
\hline 20/02/1998 & Enchente/Inundação & Avenida Comendador Alfredo Maffei altura do n 2346. & A Folha & 201448 & 7562098 \\
\hline 20/02/1998 & Enchente/Inundação & Conde do Pinhal altura do numero 1440. & A Folha & 201036 & 7562356 \\
\hline 20/02/1998 & Enchente/Inundação & Proximidades do Terminal Rodoviário. & A Folha & 199373 & 7562411 \\
\hline $20 / 02 / 1998$ & Enchente/Inundação & Rua Geminiano Costa com D. Pedro II & A Folha & 201688 & 7563868 \\
\hline 20/02/1998 & Enchente/Inundação & Baixada do Mercado & A Folha & 201913 & 7562086 \\
\hline 20/02/1998 & Enchente/Inundação & Rua Geminiano Costa com Episcopal & A Folha & 201551 & 7562083 \\
\hline 20/02/1998 & Enchente/Inundação & Comendador Alfredo Maffei próximo ao numero 2346 & A Folha & 201499 & 7562061 \\
\hline 20/02/1998 & Enchente/Inundação & Rua Geminiano Costa com Dom Pedro II & A Folha & 201448 & 7562098 \\
\hline 20/02/1998 & Enchente/Inundação & Rotatória do Cristo & A Folha & 201913 & 7562086 \\
\hline 20/02/1998 & Erosão & $\begin{array}{c}\text { Rotatória do cristo, cratera se abriu devido ao } \\
\text { escorregamento de um barranco }\end{array}$ & A Folha & 199373 & 7562411 \\
\hline 27/02/1998 & Enchente/Inundação & Rotatória do Cristo & A Folha & 199373 & 7562411 \\
\hline 27/02/1998 & Enchente/Inundação & Baixada do Mercado & A Tribuna & 201551 & 7562083 \\
\hline 27/02/1998 & Erosão & $\begin{array}{c}\text { Avenida Dr Francisco Pereira Lopes marginal próximo } \\
\text { a rotatória do Cristo }\end{array}$ & A Folha & 199414 & 7562460 \\
\hline 01/03/1998 & Alagamento & Cidade Aracy Escola Orlando Perez & A Tribuna & 200313 & 7557751 \\
\hline
\end{tabular}




\begin{tabular}{|c|c|c|c|c|c|}
\hline \multirow{2}{*}{ Data } & \multirow{2}{*}{ Eventos } & \multirow{2}{*}{ Local } & \multirow{2}{*}{ Fonte } & \multicolumn{2}{|c|}{ CA23S } \\
\hline & & & & $\mathbf{X}$ & $\mathbf{Y}$ \\
\hline 03/03/1998 & Enchente/Inundação & $\begin{array}{c}\text { Avenida Jose Pereira Lopes próximo ao Conjunto } \\
\text { Botafogo }\end{array}$ & A Folha & 199628 & 7561576 \\
\hline 29/04/1998 & Alagamento & Rua Conde do Pinhal n 935 & A Folha & 200536 & 7562408 \\
\hline 09/10/1998 & Enchente/Inundação & Rotatória do Cristo & A Folha & 199373 & 7562411 \\
\hline 09/10/1998 & Enchente/Inundação & Em frente ao Sesc de ambos os lados da avenida. & A Folha & 199976 & 7562471 \\
\hline 27/10/1998 & Erosão & $\begin{array}{l}\text { Avenida dos Trabalhadores em Frente ao edifício Solar } \\
\text { dos Engenheiros }\end{array}$ & $\begin{array}{c}\text { Primeira } \\
\text { Pagina }\end{array}$ & 201118 & 7563924 \\
\hline 08/12/1998 & Enchente/Inundação & Baixada do Mercado & A Tribuna & 201551 & 7562083 \\
\hline 08/12/1998 & Enchente/Inundação & Rotatória do Cristo & A Tribuna & 199373 & 7562411 \\
\hline 08/12/1998 & Enchente/Inundação & Baixada do Mercado & A Folha & 201448 & 7562098 \\
\hline 08/12/1998 & Enchente/Inundação & Rua Geminiano Costa próximo a 9 de Julho. & A Folha & 201399 & 7562056 \\
\hline 08/12/1998 & Erosão & Em frente ao SESC um barranco escorregou. & A Folha & 199976 & 7562471 \\
\hline $14 / 12 / 1998$ & Enchente/Inundação & Baixada do Mercado & A Folha & 201551 & 7562083 \\
\hline $14 / 12 / 1998$ & Enchente/Inundação & Rotatória do Cristo & A Folha & 199373 & 7562411 \\
\hline $14 / 12 / 1998$ & Enchente/Inundação & Área do Monjolinho atrás da Estação Rodoviária & A Folha & 201688 & 7563868 \\
\hline $14 / 12 / 1998$ & Enchente/Inundação & $\begin{array}{c}\text { Avenida Trabalhador São Carlense, em frente a } \\
\text { rotatória. }\end{array}$ & A Folha & 200603 & 7564090 \\
\hline $17 / 12 / 1998$ & Enchente/Inundação & Rotatória do Cristo & A Folha & 199373 & 7562411 \\
\hline $17 / 12 / 1998$ & Alagamento & Rotatória da Avenida Getulio Vargas. & A Folha & 203603 & 7560549 \\
\hline $17 / 12 / 1998$ & Enchente/Inundação & Em frente ao SESC & A Folha & 199976 & 7562471 \\
\hline $17 / 12 / 1998$ & Erosão & Na Rotatória do Cristo & A Folha & 199404 & 7562426 \\
\hline 17/12/1998 & Erosão & Em frente ao SESC um barranco escorregou. & A Folha & 199976 & 7562471 \\
\hline $13 / 02 / 1999$ & Enchente/Inundação & Baixada do Mercado & A Folha & 201551 & 7562083 \\
\hline 13/02/1999 & Enchente/Inundação & $\begin{array}{l}\text { Avenida Comendador Alfredo Maffei desde a esquina } \\
\text { com a Rua São Joaquim. }\end{array}$ & A Folha & 201807 & 7562078 \\
\hline 13/02/1999 & Enchente/Inundação & Rotatória do Cristo & A Folha & 199373 & 7562411 \\
\hline 21/02/1999 & Enchente/Inundação & Rotatória do Cristo & A Folha & 199373 & 7562411 \\
\hline 21/02/1999 & Enchente/Inundação & Kartódromo & A Folha & 200600 & 7564344 \\
\hline 21/02/1999 & Enchente/Inundação & Kartódromo & A Folha & 200600 & 7564344 \\
\hline 21/02/1999 & Movimento de encosta & $\begin{array}{c}\text { Movimento de encosta nas proximidades do Parque } \\
\text { Faber }\end{array}$ & A Folha & 199408 & 7562521 \\
\hline $30 / 03 / 2001$ & Enchente/Inundação & Baixada do Mercado & A Folha & 201551 & 7562083 \\
\hline $15 / 12 / 2001$ & Enchente/Inundação & Rotatória do Cristo & A Folha & 199373 & 7562411 \\
\hline $15 / 12 / 2001$ & Enchente/Inundação & Baixada do Mercado & A Folha & 201551 & 7562083 \\
\hline $15 / 12 / 2001$ & Enchente/Inundação & Kartódromo & A Folha & 200600 & 7564344 \\
\hline 09/01/2002 & Enchente/Inundação & Baixada do Mercado ( Episcopal) & A Folha & 201500 & 7562089 \\
\hline 09/01/2002 & Enchente/Inundação & Rotatória do Cristo & A Folha & 199373 & 7562411 \\
\hline 09/01/2002 & Enchente/Inundação & $\begin{array}{c}\text { Baixada do Mercado ( Avenida Comendador Alfredo } \\
\text { Maffei) }\end{array}$ & A Folha & 201448 & 7562098 \\
\hline $09 / 01 / 2002$ & Enchente/Inundação & Baixada do Mercado (Geminiano costa) & A Folha & 201552 & 7562066 \\
\hline 09/01/2002 & Enchente/Inundação & Baixada do Mercado (9 de julho) & A Folha & 201399 & 7562056 \\
\hline 09/01/2002 & Enchente/Inundação & Baixada do Mercado (Jesuino de Arruda) & A Folha & 201549 & 7562168 \\
\hline 09/01/2002 & Erosão & $\begin{array}{l}\text { Proximidade do Sesc sentido Shopping } \\
\text { desmoronamento da encosta do Córrego }\end{array}$ & A Folha & 199960 & 7562467 \\
\hline $10 / 11 / 2002$ & Alagamento & Praça Itália & A Tribuna & 201636 & 7560747 \\
\hline $10 / 11 / 2002$ & Enchente/Inundação & Rotatória do Cristo & A Tribuna & 199373 & 7562411 \\
\hline $10 / 11 / 2002$ & Enchente/Inundação & Baixada do Mercado & A Tribuna & 201551 & 7562083 \\
\hline $13 / 12 / 2002$ & Enchente/Inundação & Rotatória do Cristo & $\begin{array}{c}\text { Primeira } \\
\text { Pagina }\end{array}$ & 199373 & 7562411 \\
\hline $15 / 12 / 2002$ & Enchente/Inundação & Kartódromo & $\begin{array}{c}\text { Primeira } \\
\text { Pagina }\end{array}$ & 200600 & 7564344 \\
\hline $15 / 12 / 2002$ & Enchente/Inundação & Rotatória do Cristo & Primeira & 199373 & 7562411 \\
\hline
\end{tabular}




\begin{tabular}{|c|c|c|c|c|c|}
\hline \multirow{2}{*}{ Data } & \multirow{2}{*}{ Eventos } & \multirow{2}{*}{ Local } & \multirow{2}{*}{ Fonte } & \multicolumn{2}{|c|}{ CA23S } \\
\hline & & & & $\mathbf{X}$ & $\mathbf{Y}$ \\
\hline & & & Pagina & & \\
\hline 03/01/2003 & Enchente/Inundação & Kartódromo & A Tribuna & 200600 & 7564344 \\
\hline 03/01/2003 & Enchente/Inundação & Baixada do Mercado & A Tribuna & 201551 & 7562083 \\
\hline 03/01/2003 & Enchente/Inundação & Rotatória do Cristo & A Tribuna & 199373 & 7562411 \\
\hline $03 / 01 / 2003$ & Alagamento & Praça Itália & A Tribuna & 201636 & 7560747 \\
\hline $17 / 01 / 2003$ & Enchente/Inundação & Kartódromo & $\begin{array}{l}\text { Primeira } \\
\text { Pagina }\end{array}$ & 200600 & 7564344 \\
\hline 28/01/2003 & Erosão & $\begin{array}{l}\text { Margens do Córrego Santa Maria, região do } \\
\text { Kartodromo, devido a retirada de vegetação }\end{array}$ & $\begin{array}{c}\text { Primeira } \\
\text { Pagina } \\
\end{array}$ & 200892 & 7564488 \\
\hline 07/03/2003 & Enchente/Inundação & Kartódromo & $\begin{array}{c}\text { Primeira } \\
\text { Pagina }\end{array}$ & 200600 & 7564344 \\
\hline $07 / 03 / 2003$ & Enchente/Inundação & Rotatória do Cristo & $\begin{array}{c}\text { Primeira } \\
\text { Pagina }\end{array}$ & 199373 & 7562411 \\
\hline 07/03/2003 & Enchente/Inundação & Baixada do Mercado & $\begin{array}{l}\text { Primeira } \\
\text { Pagina }\end{array}$ & 201551 & 7562083 \\
\hline $15 / 03 / 2003$ & Alagamento & Rua Icaraí no Jardim Morumbi & A Tribuna & 202096 & 7559864 \\
\hline $30 / 01 / 2004$ & Enchente/Inundação & Baixada do Mercado & A Folha & 201551 & 7562083 \\
\hline $30 / 01 / 2004$ & Enchente/Inundação & Rotatória do Cristo & A Folha & 199373 & 7562411 \\
\hline 03/03/2004 & Erosão & $\begin{array}{l}\text { Hercules Sachi com Manoel Wenzel Bairro Monte } \\
\text { Carlo, próximo ao local que ocorreu escorregamento }\end{array}$ & A Folha & 201318 & 7558740 \\
\hline 03/03/2004 & Movimento de encosta & $\begin{array}{l}\text { Escorregamento nas proximidades das rua Hércules } \\
\text { Sacchi com Manoel Wenzel no bairro Monte Carlo }\end{array}$ & A Folha & 201273 & 7558642 \\
\hline $19 / 12 / 2004$ & Enchente/Inundação & Baixada do Mercado & $\begin{array}{c}\text { Primeira } \\
\text { Pagina }\end{array}$ & 201551 & 7562083 \\
\hline $09 / 01 / 2005$ & Erosão & $\begin{array}{l}\text { Avenida Comendador Alfredo Maffei proximo a } \\
\text { entrada do Jardim Gilbertoni - no Corrego do Gregório }\end{array}$ & A Folha & 199903 & 7562401 \\
\hline $02 / 06 / 2005$ & Movimento de encosta & - & Mosaico & 201497 & 7558598 \\
\hline $14 / 10 / 2005$ & Colapso de solo & Rua Joaquim Garcia Oliveira 22 & Defesa Civil & 200639 & 7557605 \\
\hline $16 / 12 / 2005$ & Enchente/Inundação & $\begin{array}{l}\text { Baixada do Mercado (Cruzamento das ruas Geminiano } \\
\text { Costa e } 9 \text { de Julho) }\end{array}$ & $\begin{array}{c}\text { Primeira } \\
\text { Pagina } \\
\end{array}$ & 201399 & 7562056 \\
\hline $16 / 12 / 2005$ & Alagamento & Praça Itália & $\begin{array}{c}\text { Primeira } \\
\text { Pagina } \\
\end{array}$ & 201636 & 7560747 \\
\hline $16 / 12 / 2005$ & Enchente/Inundação & Rotatória do Cristo & $\begin{array}{c}\text { Primeira } \\
\text { Pagina }\end{array}$ & 199373 & 7562411 \\
\hline $16 / 12 / 2005$ & Alagamento & $\mathrm{CDHU}$ & $\begin{array}{c}\text { Primeira } \\
\text { Pagina }\end{array}$ & 202315 & 7560180 \\
\hline $18 / 01 / 2007$ & Erosão & Rua Dr Astor Dias Andrade 1815 & Defesa Civil & 203402 & 7562720 \\
\hline $19 / 01 / 2007$ & Alagamento & Rua Dr Beijamin Lopes Soares 04, 08, 15 e 19 & Defesa Civil & 199586 & 7563343 \\
\hline $24 / 01 / 2007$ & Alagamento & Rua João Lourenço Rodrigues & Defesa Civil & 201636 & 7560747 \\
\hline $24 / 01 / 2007$ & Alagamento & Rua República do Líbano próximo do número 20 & Defesa Civil & 201286 & 7560257 \\
\hline $24 / 01 / 2007$ & Colapso de solo & Rua Haiti 232 (Casa com trincas) & Defesa Civil & 202699 & 7564862 \\
\hline $28 / 01 / 2007$ & Alagamento & Avenida Getúlio Vargas & Defesa Civil & 203088 & 7560615 \\
\hline $28 / 01 / 2007$ & Enchente/Inundação & $\begin{array}{c}\text { Avenida Comendador Alfredo Maffei, próximo ao } \\
\text { Bingo Metropolitan }\end{array}$ & Defesa Civil & 202220 & 7562036 \\
\hline $08 / 02 / 2007$ & Alagamento & CDHU & Defesa Civil & 202315 & 7560180 \\
\hline 08/02/2007 & Alagamento & Praça Itália & Defesa Civil & 201636 & 7560747 \\
\hline $08 / 02 / 2007$ & Enchente/Inundação & Rotatória do Cristo & Defesa Civil & 199373 & 7562411 \\
\hline $08 / 02 / 2007$ & Alagamento & Rua Itália Próximo a linha de trem & Defesa Civil & 201352 & 7561124 \\
\hline 08/02/2007 & Alagamento & Rua Luiz Paulino dos Santos 167 & Defesa Civil & 199197 & 7558614 \\
\hline $08 / 02 / 2007$ & Alagamento & Rua Luiz Paulino dos Santos 162 & Defesa Civil & 199197 & 7558614 \\
\hline $21 / 02 / 2007$ & Colapso de solo & Rua Dr. Pedro Raimundo 339 (Casa com trincas) & Defesa Civil & 199551 & 7561366 \\
\hline $27 / 02 / 2007$ & Colapso de solo & Rua Raimundo Correa 323 (Casa com trincas) & Defesa Civil & 201953 & 7561369 \\
\hline $04 / 06 / 2007$ & Colapso de solo & Rua Padre Teixeira 1474 (Casa com trincas) & Defesa Civil & 201022 & 7562753 \\
\hline $17 / 07 / 2007$ & Colapso de solo & Rua Santa Filomena 250 (Casa com trincas) & Defesa Civil & 202483 & 7560510 \\
\hline $24 / 07 / 2007$ & Erosão & Ponte de Madeira do Aracy Dois & Defesa Civil & 200694 & 7558436 \\
\hline
\end{tabular}




\begin{tabular}{|c|c|c|c|c|c|}
\hline \multirow{2}{*}{ Data } & \multirow{2}{*}{ Eventos } & \multirow{2}{*}{ Local } & \multirow{2}{*}{ Fonte } & \multicolumn{2}{|c|}{ CA23S } \\
\hline & & & & $\mathbf{X}$ & $\mathbf{Y}$ \\
\hline 25/07/2007 & Erosão & Rua Totó Leite no pé da ponte & Defesa Civil & 202724 & 7561674 \\
\hline $27 / 07 / 2007$ & Erosão & $\begin{array}{c}\text { Avenida Paulo de Arruda Correa da Silva no pé da } \\
\text { ponte }\end{array}$ & Defesa Civil & 199491 & 7561903 \\
\hline $31 / 08 / 2007$ & Colapso de solo & $\begin{array}{c}\text { Rua Paulino Botelho de Abreu Sampaio } 1057 \text { (Casa } \\
\text { com trincas) }\end{array}$ & Defesa Civil & 200511 & 7563486 \\
\hline 05/09/2007 & Colapso de solo & $\begin{array}{c}\text { Rua Alameda das Hortências } 800 \text { (Apartamento com } \\
\text { trincas) }\end{array}$ & Defesa Civil & 201186 & 7564789 \\
\hline $01 / 10 / 2007$ & Colapso de solo & Rua Major Manoel de Matos 1238 (Casa com trincas) & Defesa Civil & 202605 & 7562364 \\
\hline $11 / 11 / 2007$ & Colapso de solo & $\begin{array}{l}\text { Rua Carlos Ribeiro Justiniano das Chagas } 395 \text { (Casa } \\
\text { com trincas) }\end{array}$ & Defesa Civil & 202033 & 7558955 \\
\hline $07 / 12 / 2007$ & Enchente/Inundação & Baixada do Mercado & $\begin{array}{l}\text { São Carlos } \\
\text { Agora }\end{array}$ & 201551 & 7562083 \\
\hline $07 / 12 / 2007$ & Alagamento & Praça Itália & $\begin{array}{l}\text { São Carlos } \\
\text { Agora }\end{array}$ & 201636 & 7560747 \\
\hline 07/12/2007 & Enchente/Inundação & Rotatória do Cristo & $\begin{array}{l}\text { São Carlos } \\
\text { Agora }\end{array}$ & 199373 & 7562411 \\
\hline $07 / 12 / 2007$ & Alagamento & Rotatória do CDHU & $\begin{array}{l}\text { São Carlos } \\
\text { Agora }\end{array}$ & 202315 & 7560180 \\
\hline $12 / 12 / 2007$ & Movimento de encosta & $\begin{array}{l}\text { Queda de blocos na Avenida Integração na curva da } \\
\text { Serra de Aracy }\end{array}$ & Defesa Civil & 200738 & 7558836 \\
\hline $21 / 12 / 2007$ & Colapso de solo & Rua 13 de maio 1836 (Muro com trincas) & Defesa Civil & 201447 & 7562244 \\
\hline $22 / 01 / 2008$ & Colapso de solo & $\begin{array}{c}\text { Rua Luiz Paulino dos Santos } 256 \text { e } 258 \text { (casas com } \\
\text { trincas) }\end{array}$ & Defesa Civil & 199036 & 7558445 \\
\hline 29/01/2008 & Enchente/Inundação & $\begin{array}{c}\text { Eliza Gonzáles e Avenida Francisco Pereira Lopes } \\
\text { (Próximo ao Kartódromo) }\end{array}$ & Defesa Civil & 200600 & 7564344 \\
\hline 04/02/2008 & Erosão & $\begin{array}{c}\text { Avenida Paulo de Arruda Correa da Silva no pé da } \\
\text { ponte }\end{array}$ & Defesa Civil & 199491 & 7561903 \\
\hline $18 / 02 / 2008$ & Alagamento & Avenida São Carlos com a Rua Machado de Assis. & Defesa Civil & 201592 & 7561017 \\
\hline $18 / 02 / 2008$ & Alagamento & Pontilhão da Travessa 8 & Defesa Civil & 201352 & 7561124 \\
\hline $18 / 02 / 2008$ & Alagamento & Praça Itália & Defesa Civil & 201636 & 7560747 \\
\hline $18 / 02 / 2008$ & Enchente/Inundação & Rua Episcopal com a Rua General Osório. & Defesa Civil & 201504 & 7561959 \\
\hline $25 / 02 / 2008$ & Colapso de solo & Rua Conselheiro Soares Brandão 11 (Casa com trincas) & Defesa Civil & 200624 & 7563566 \\
\hline $04 / 03 / 2008$ & Erosão & Rua Coronel Leopoldo Prado 75 & Defesa Civil & 201556 & 7560717 \\
\hline 08/03/2008 & Enchente/Inundação & $\begin{array}{c}\text { Rua Geminiano Costa, entre a Avenida São Carlos e a } \\
\text { Rua Episcopal }\end{array}$ & Defesa Civil & 201552 & 7562066 \\
\hline 08/03/2008 & Enchente/Inundação & Região do Mercado & Defesa Civil & 201551 & 7562083 \\
\hline $11 / 03 / 2008$ & Erosão & $\begin{array}{c}\text { Rua Marcolino Pelicano, esquina com a Rua Cândido } \\
\text { Padim }\end{array}$ & Defesa Civil & 200927 & 7561830 \\
\hline $16 / 04 / 2008$ & Enchente/Inundação & Corrego do Gregório na altura da Rua São Joaquim & $\begin{array}{l}\text { São Carlos } \\
\text { Agora }\end{array}$ & 201807 & 7562078 \\
\hline $16 / 04 / 2008$ & Erosão & Rua Luiz Roher Esquina com a Rua Vicente D'Aquino & Defesa Civil & 202949 & 7561425 \\
\hline $10 / 06 / 2008$ & Colapso de solo & $\begin{array}{c}\text { Rua Ângelo Passeri } 281 \text { Jardim Alvorada (Casa com } \\
\text { varais trincas) }\end{array}$ & Defesa Civil & 199845 & 7563405 \\
\hline $01 / 10 / 2008$ & Alagamento & Avenida Getúlio Vargas & Defesa Civil & 203088 & 7560615 \\
\hline $01 / 10 / 2008$ & Enchente/Inundação & $\begin{array}{l}\text { Rua São Joaquim Esquina com Avenida Comendador } \\
\text { Alfredo Maffei. }\end{array}$ & Defesa Civil & 201807 & 7562078 \\
\hline $01 / 10 / 2008$ & Alagamento & Avenida Getúlio Vargas & Defesa Civil & 204221 & 7560466 \\
\hline $01 / 10 / 2008$ & Erosão & Rua Guatemala com Rua Colômbia & Defesa Civil & 202713 & 7564697 \\
\hline $05 / 11 / 2008$ & Movimento de encosta & Serra do Cidade Aracy & Defesa Civil & 200738 & 7558836 \\
\hline $27 / 11 / 2008$ & Colapso de solo & $\begin{array}{c}\text { Rua Miguel Donofrio 25, Santa Argelina (casa com } \\
\text { trincas) }\end{array}$ & Defesa Civil & 197883 & 7564563 \\
\hline 08/12/2008 & Erosão & Paulino Botelho Sampaio com Maria Jascinta. & Defesa Civil & 200519 & 7563370 \\
\hline $08 / 12 / 2008$ & Erosão & Rua Mozart Santos 95. & Defesa Civil & 202201 & 7564350 \\
\hline $08 / 12 / 2008$ & Erosão & Rua Irineu Rios 140 & Defesa Civil & 199834 & 7559810 \\
\hline $12 / 12 / 2008$ & Erosão & Avenida José Gonçalves Carneiro 801 & Defesa Civil & 200019 & 7563070 \\
\hline $25 / 12 / 2008$ & Erosão & Rua Machado de Assis 80 & Defesa Civil & 201592 & 7561017 \\
\hline $26 / 12 / 2008$ & Erosão & Rua Episcopal 811 & Defesa Civil & 201508 & 7561852 \\
\hline 01/01/2009 & Alagamento & Rua Conselheiro Soares Brandão 234. & Defesa Civil & 200422 & 7563562 \\
\hline
\end{tabular}




\begin{tabular}{|c|c|c|c|c|c|}
\hline \multirow{2}{*}{ Data } & \multirow{2}{*}{ Eventos } & \multirow{2}{*}{ Local } & \multirow{2}{*}{ Fonte } & \multicolumn{2}{|c|}{ CA23S } \\
\hline & & & & $\mathbf{X}$ & $\mathbf{Y}$ \\
\hline 08/01/2009 & Erosão & Rua Miguel Giometti de frente ao posto de gasolina & Defesa Civil & 202557 & 7563727 \\
\hline 09/01/2009 & Colapso de solo & Rua Santa Clotilde 368 (Casa com trincas e afundando) & Defesa Civil & 202277 & 7560435 \\
\hline 09/01/2009 & Colapso de solo & Rua São Paulo 2846 (Casa com trincas) & Defesa Civil & 202048 & 7564268 \\
\hline 06/02/2009 & Movimento de encosta & $\begin{array}{c}\text { Queda de blocos na Avenida Integração na curva da } \\
\text { Serra de Aracy }\end{array}$ & Defesa Civil & 200738 & 7558836 \\
\hline $15 / 02 / 2009$ & Colapso de solo & Rua Jesuino de Arruda 1166 (Casa com trincas) & Defesa Civil & 200676 & 7562121 \\
\hline $16 / 02 / 2009$ & Erosão & Avenida Morumbi a 100 metros do Pontilhão & Defesa Civil & 201669 & 7560592 \\
\hline $17 / 02 / 2009$ & Colapso de solo & $\begin{array}{c}\text { Rua Conselheiro Soares Brandão } 234 \text { (Casa com } \\
\text { trincas) }\end{array}$ & Defesa Civil & 200422 & 7563562 \\
\hline $18 / 02 / 2009$ & Colapso de solo & Rua Padre Texeira 1474 (Casa com trincas) & Defesa Civil & 201022 & 7562753 \\
\hline $19 / 02 / 2009$ & Colapso de solo & Rua Sete de Setembro 2258 (Casa com trincas) & Defesa Civil & 201821 & 7562575 \\
\hline $19 / 02 / 2009$ & Colapso de solo & Rua Campo Sales 29 (Casa com trincas) & Defesa Civil & 202190 & 7563072 \\
\hline $26 / 02 / 2009$ & Erosão & $\begin{array}{c}\text { Comendador Alfredo Maffei sentido Shopping - Sesc, } \\
\text { margem do Gregório }\end{array}$ & A Tribuna & 199960 & 7562467 \\
\hline $11 / 03 / 2009$ & Enchente/Inundação & Rua Rafael Tomazio com Antônio Passos Caldas & Defesa Civil & 201060 & 7565496 \\
\hline $11 / 03 / 2009$ & Erosão & $\begin{array}{l}\text { Rua Ananias Evangelista de Toledo com Avenida } \\
\text { Henrique Gregori }\end{array}$ & Defesa Civil & 200192 & 7560920 \\
\hline $11 / 03 / 2009$ & Erosão & Avenida Francisco Pereira Lopes 2550 & Defesa Civil & 200568 & 7564118 \\
\hline $11 / 03 / 2009$ & Colapso de solo & Rua Episcopal 2593 & Defesa Civil & 201442 & 7563537 \\
\hline $30 / 03 / 2009$ & Alagamento & Praça Itália & Defesa Civil & 201636 & 7560747 \\
\hline 06/04/2009 & Enchente/Inundação & Avenida São Carlos proximo ao Jáu Serve & Defesa Civil & 201538 & 7563831 \\
\hline 06/04/2009 & Enchente/Inundação & $\begin{array}{c}\text { Avenida Francisco Pereira Lopes sentido } \\
\text { centro/shopping }\end{array}$ & $\begin{array}{c}\text { São Carlos } \\
\text { Agora }\end{array}$ & 199504 & 7562540 \\
\hline $10 / 04 / 2009$ & Erosão & Rua José Gonçalves Carneiro 798 & Defesa Civil & 199993 & 7562933 \\
\hline $22 / 04 / 2009$ & Erosão & Rua José Gonçalves Carneiro 801 & Defesa Civil & 199993 & 7562933 \\
\hline $23 / 04 / 2009$ & Erosão & Rua Adolpho Catani com Rui Barbosa & Defesa Civil & 201956 & 7563604 \\
\hline $26 / 06 / 2009$ & Colapso de solo & $\begin{array}{c}\text { Afundameno do asfalto na Rua Jacinto Favoretto com } \\
\text { D. Pedro II, prejudicando casas. }\end{array}$ & Defesa Civil & 201847 & 7563702 \\
\hline 23/07/2009 & Erosão & Rua São Gabriel com José Gibertoni & Defesa Civil & 199584 & 7561900 \\
\hline $24 / 07 / 2009$ & Erosão & $\begin{array}{l}\text { Avenida Comendador Alfredo Maffei } 4001 \text { na margem } \\
\text { do rio }\end{array}$ & Defesa Civil & 203057 & 7561567 \\
\hline $17 / 08 / 2009$ & Erosão & $\begin{array}{c}\text { Avenida Comendador Alfredo Maffei, entre as Ruas } \\
\text { Rui Barbosa e Dom Pedro II }\end{array}$ & Defesa Civil & 201966 & 7562075 \\
\hline 28/08/2009 & Colapso de solo & $\begin{array}{l}\text { Afundamento do asfalto na Rua Episcopal entre Bento } \\
\text { Carlos e Santa Cruz, prejudicando casas }\end{array}$ & Defesa Civil & 201509 & 7561805 \\
\hline $31 / 08 / 2009$ & Erosão & Rua Dr Pedro Souza Campos Filho 212 & Defesa Civil & 201275 & 7560680 \\
\hline $31 / 08 / 2009$ & Colapso de solo & Rua Julio Casin 205 (Casa com trincas) & Defesa Civil & 198520 & 7564235 \\
\hline $08 / 09 / 2009$ & Colapso de solo & Rua Padre Texeira 1474 (Casa com trincas) & Defesa Civil & 201022 & 7562753 \\
\hline $15 / 09 / 2009$ & Colapso de solo & Rua José Marrara 102 (Casa com trincas) & Defesa Civil & 203304 & 7561988 \\
\hline $15 / 09 / 2009$ & Colapso de solo & Rua Conde do Pinhal 1085 & Defesa Civil & 200680 & 7562390 \\
\hline $12 / 10 / 2009$ & Enchente/Inundação & Praça do Mercado & Defesa Civil & 201551 & 7562083 \\
\hline $24 / 10 / 2009$ & Erosão & Antiga rua 14 - Francisco Cereda 592 & Defesa Civil & 201142 & 7557821 \\
\hline $26 / 10 / 2009$ & Alagamento & Rua Machado de Assis 80 & Defesa Civil & 201592 & 7561017 \\
\hline $26 / 10 / 2009$ & Alagamento & Rua 26 Cidade Aracy & Defesa Civil & 200700 & 7557210 \\
\hline $26 / 10 / 2009$ & Alagamento & Rua Rigiti Arab 267 & Defesa Civil & 200910 & 7557957 \\
\hline $26 / 10 / 2009$ & Alagamento & Praça Itália & Defesa Civil & 201636 & 7560747 \\
\hline $26 / 10 / 2009$ & Alagamento & $\mathrm{CDHU}$ & Defesa Civil & 202315 & 7560180 \\
\hline $26 / 10 / 2009$ & Enchente/Inundação & Rotatória do Cristo & $\begin{array}{l}\text { São Carlos } \\
\text { Agora }\end{array}$ & 199373 & 7562411 \\
\hline $26 / 10 / 2009$ & Erosão & Rua Rigiti arab em frente ao Banco do Brasil & Defesa Civil & 201057 & 7558061 \\
\hline $27 / 10 / 2009$ & Erosão & $\begin{array}{c}\text { Avenida Comendador Alfredo Maffei entre as Ruas D. } \\
\text { Pedrro e Rui Barbosa }\end{array}$ & Defesa Civil & 201966 & 7562075 \\
\hline $27 / 11 / 2009$ & Colapso de solo & Rua Nações Unidas 282 (Casa com trincas) & Defesa Civil & 201562 & 7559592 \\
\hline
\end{tabular}




\begin{tabular}{|c|c|c|c|c|c|}
\hline \multirow{2}{*}{ Data } & \multirow{2}{*}{ Eventos } & \multirow{2}{*}{ Local } & \multirow{2}{*}{ Fonte } & \multicolumn{2}{|c|}{ CA23S } \\
\hline & & & & $\mathbf{X}$ & $\mathbf{Y}$ \\
\hline $30 / 11 / 2009$ & Erosão & Rua Conde do Pinhal com Major M. Antônio de Mattos & Defesa Civil & 202606 & 7562415 \\
\hline $02 / 12 / 2009$ & Movimento de encosta & $\begin{array}{c}\text { Movimento de encosta no morro da Cidade Aracy } \\
\text { sobre a Avenida da Integração, obstruindo a via pública }\end{array}$ & Defesa Civil & 200738 & 7558836 \\
\hline $05 / 12 / 2009$ & Colapso de solo & Rua Nações Unidas 282 (Casa com trincas) & Defesa Civil & 201562 & 7559592 \\
\hline $07 / 12 / 2009$ & Erosão & Rua Dr Pedro Souza Campos Filho 212 (Erosão) & Defesa Civil & 201275 & 7560680 \\
\hline $12 / 12 / 2009$ & Colapso de solo & Afundamento da Rua Lourenço Inocentini 596 & Defesa Civil & 203922 & 7563233 \\
\hline $13 / 12 / 2009$ & Colapso de solo & $\begin{array}{l}\text { Afundamento de solo na Avenida Paulo de A Correia da } \\
\text { Silva } 665\end{array}$ & Defesa Civil & 199187 & 7561543 \\
\hline $15 / 12 / 2009$ & Colapso de solo & Rua Mario Migliato 45 (Casa com trincas) & Defesa Civil & 202356 & 7560784 \\
\hline $16 / 12 / 2009$ & Enchente/Inundação & Kartódromo & Defesa Civil & 200600 & 7564344 \\
\hline $16 / 12 / 2009$ & Erosão & Rua Francisco Crestana 103 & Defesa Civil & 203559 & 7563283 \\
\hline 29/12/2009 & Enchente/Inundação & Avenida Francisco Pereira Lopes & Defesa Civil & 199504 & 7562540 \\
\hline $29 / 12 / 2009$ & Enchente/Inundação & Rotatória do Cristo & Defesa Civil & 199373 & 7562411 \\
\hline $29 / 12 / 2009$ & Alagamento & Avenida Getulio Vargas 1405 & Defesa Civil & 203088 & 7560615 \\
\hline $29 / 12 / 2009$ & Erosão & Travessa Franscisco Parrota 310 & Defesa Civil & 201207 & 7559144 \\
\hline $31 / 12 / 2009$ & Alagamento & Praça Itália & Defesa Civil & 201636 & 7560747 \\
\hline $14 / 03 / 2010$ & Enchente/Inundação & Rua Conde do Pinhal - Perto da creche Anita Costa & $\begin{array}{l}\text { São Carlos } \\
\text { Agora }\end{array}$ & 201080 & 7562366 \\
\hline $14 / 03 / 2010$ & Enchente/Inundação & Rotatória do Cristo & $\begin{array}{l}\text { São Carlos } \\
\text { Agora }\end{array}$ & 199373 & 7562411 \\
\hline $14 / 03 / 2010$ & Enchente/Inundação & $\begin{array}{c}\text { Rotatória da Educativa na Avenida Comendador } \\
\text { Alfredo Maffei }\end{array}$ & $\begin{array}{l}\text { São Carlos } \\
\text { Agora }\end{array}$ & 203570 & 7561431 \\
\hline $14 / 03 / 2010$ & Enchente/Inundação & Baixada do Mercado & $\begin{array}{c}\text { São Carlos } \\
\text { Agora }\end{array}$ & 201551 & 7562083 \\
\hline $14 / 03 / 2010$ & Alagamento & Praça Itália & $\begin{array}{l}\text { São Carlos } \\
\text { Agora }\end{array}$ & 201636 & 7560747 \\
\hline 03/04/2010 & Enchente/Inundação & Rotatória do Cristo & $\begin{array}{l}\text { São Carlos } \\
\text { Agora }\end{array}$ & 199373 & 7562411 \\
\hline 03/04/2010 & Enchente/Inundação & Baixada do Mercado & $\begin{array}{l}\text { São Carlos } \\
\text { Agora }\end{array}$ & 201551 & 7562083 \\
\hline 03/04/2010 & Alagamento & Praça Itália & $\begin{array}{l}\text { São Carlos } \\
\text { Agora }\end{array}$ & 201636 & 7560747 \\
\hline 03/04/2010 & Enchente/Inundação & $\begin{array}{c}\text { Rotátoria da Educativa na Avenida Comendador } \\
\text { Alfredo Maffei }\end{array}$ & $\begin{array}{l}\text { São Carlos } \\
\text { Agora }\end{array}$ & 203570 & 7561431 \\
\hline 03/04/2010 & Enchente/Inundação & Comendador Alfredo Maffei, perto do Forum Civel & $\begin{array}{l}\text { São Carlos } \\
\text { Agora }\end{array}$ & 202220 & 7562036 \\
\hline $18 / 10 / 2010$ & Erosão & - & Mosaico & 199252 & 7558533 \\
\hline $18 / 10 / 2010$ & Erosão & - & Mosaico & 199270 & 7558452 \\
\hline $17 / 11 / 2010$ & Movimento de encosta & - & Mosaico & 198024 & 7561437 \\
\hline $17 / 11 / 2010$ & Movimento de encosta & - & Mosaico & 198141 & 7561296 \\
\hline $17 / 11 / 2010$ & Movimento de encosta & - & Mosaico & 198089 & 7561168 \\
\hline $17 / 11 / 2010$ & Movimento de encosta & - & Mosaico & 198216 & 7561082 \\
\hline $17 / 11 / 2010$ & Movimento de encosta & - & Mosaico & 197939 & 7560956 \\
\hline $17 / 11 / 2010$ & Movimento de encosta & - & Mosaico & 199036 & 7560551 \\
\hline $17 / 11 / 2010$ & Movimento de encosta & - & Mosaico & 200941 & 7559650 \\
\hline $17 / 11 / 2010$ & Movimento de encosta & - & Mosaico & 196273 & 7561067 \\
\hline $17 / 11 / 2010$ & Movimento de encosta & - & Mosaico & 196412 & 7561002 \\
\hline $17 / 11 / 2010$ & Movimento de encosta & - & Mosaico & 197981 & 7561886 \\
\hline $17 / 11 / 2010$ & Movimento de encosta & - & Mosaico & 201294 & 7559606 \\
\hline $17 / 11 / 2010$ & Movimento de encosta & - & Mosaico & 201252 & 7559590 \\
\hline $17 / 11 / 2010$ & Movimento de encosta & - & Mosaico & 206440 & 7559141 \\
\hline $12 / 01 / 2011$ & Enchente/Inundação & Rotatória do Cristo & Defesa Civil & 199373 & 7562411 \\
\hline $12 / 01 / 2011$ & Alagamento & Rua da Paz - CDHU & Defesa Civil & 202344 & 7560231 \\
\hline $12 / 01 / 2011$ & Movimento de encosta & Lourenço Inocentini próximo a rodovia Washington & Defesa Civil & 204748 & 7563285 \\
\hline
\end{tabular}




\begin{tabular}{|c|c|c|c|c|c|}
\hline \multirow{2}{*}{ Data } & \multirow{2}{*}{ Eventos } & \multirow{2}{*}{ Local } & \multirow{2}{*}{ Fonte } & \multicolumn{2}{|c|}{ CA23S } \\
\hline & & & & $\mathbf{X}$ & $\mathbf{Y}$ \\
\hline & & Luiz & & & \\
\hline $12 / 01 / 2011$ & Colapso de solo & Dona Alexandrina 878 & Defesa Civil & 201707 & 7562324 \\
\hline $13 / 01 / 2011$ & Colapso de solo & Rua Gastão Vieira 304 & Defesa Civil & 199031 & 7564324 \\
\hline $25 / 01 / 2011$ & Colapso de solo & Rua Manoel Martins 654 & Defesa Civil & 204879 & 7564200 \\
\hline $29 / 01 / 2011$ & Enchente/Inundação & Rotatória do Cristo & $\begin{array}{l}\text { São Carlos } \\
\text { Agora }\end{array}$ & 199373 & 7562411 \\
\hline $29 / 01 / 2011$ & Alagamento & $\mathrm{CDHU}$ & $\begin{array}{l}\text { São Carlos } \\
\text { Agora }\end{array}$ & 202315 & 7560180 \\
\hline $31 / 01 / 2011$ & Alagamento & $\begin{array}{c}\text { Rua Natalino Sampato (antiga 26) no Bairro Cidade } \\
\text { Aracy II }\end{array}$ & $\begin{array}{l}\text { São Carlos Dia } \\
\text { e Noite }\end{array}$ & 200700 & 7557210 \\
\hline $31 / 01 / 2011$ & Enchente/Inundação & Rua General Osório em frente a loja Pernanbucanas. & Defesa Civil & 201504 & 7561959 \\
\hline $31 / 01 / 2011$ & Enchente/Inundação & Rua Jose Bonifacio & Defesa Civil & 201288 & 7562165 \\
\hline $31 / 01 / 2011$ & Alagamento & Rua Francisco Marmorato & Defesa Civil & 201458 & 7561113 \\
\hline $31 / 01 / 2011$ & Alagamento & Rua 26 Cidade Aracy & Defesa Civil & 200700 & 7557210 \\
\hline $31 / 01 / 2011$ & Alagamento & Rua Icaraí & Defesa Civil & 202096 & 7559864 \\
\hline $31 / 01 / 2011$ & Alagamento & $\mathrm{CDHU}$ & $\begin{array}{l}\text { São Carlos } \\
\text { Agora }\end{array}$ & 202315 & 7560180 \\
\hline $31 / 01 / 2011$ & Movimento de encosta & Avenida Integração Serra da Cidade Aracy & Defesa Civil & 200738 & 7558836 \\
\hline $01 / 02 / 2011$ & Enchente/Inundação & Rua Episcopal na Área do Mercado & $\begin{array}{l}\text { São Carlos } \\
\text { Agora }\end{array}$ & 201499 & 7562061 \\
\hline $02 / 02 / 2011$ & Enchente/Inundação & Rotatória do Cristo & $\begin{array}{l}\text { São Carlos } \\
\text { Agora }\end{array}$ & 199373 & 7562411 \\
\hline $02 / 02 / 2011$ & Alagamento & Linha Férrea na Travessa 8 & $\begin{array}{l}\text { São Carlos } \\
\text { Agora }\end{array}$ & 201352 & 7561124 \\
\hline $04 / 02 / 2011$ & Erosão & $\begin{array}{l}\text { A ponte que liga os Bairros Tijuco Preto - Vila } \\
\text { Elisabeth, na Rua Marcolino Lopes Barreto }\end{array}$ & $\begin{array}{l}\text { São Carlos Dia } \\
\text { e Noite }\end{array}$ & 202507 & 7561848 \\
\hline $14 / 02 / 2011$ & Colapso de solo & Rua Jesuino de Arruda 2620 & Defesa Civil & 202138 & 7562171 \\
\hline $23 / 02 / 2011$ & Alagamento & Rua Reginaldo Ste Fanutte 1050 & Defesa Civil & 200793 & 7557210 \\
\hline $23 / 02 / 2011$ & Alagamento & Avenida Getulio Vargas (Rotatória) & Defesa Civil & 203603 & 7560549 \\
\hline $23 / 02 / 2011$ & Alagamento & Rua Desembargador Julio de Faria 1913 & Defesa Civil & 199602 & 7560127 \\
\hline $23 / 02 / 2011$ & Movimento de encosta & Rua 13 de maio & Defesa Civil & 200345 & 7562193 \\
\hline $26 / 02 / 2011$ & Enchente/Inundação & Rotatória do Cristo & $\begin{array}{l}\text { São Carlos } \\
\text { Agora }\end{array}$ & 199373 & 7562411 \\
\hline $28 / 02 / 2011$ & Movimento de encosta & Cidade Aracy - Descida da Serra & Defesa Civil & 200738 & 7558836 \\
\hline $12 / 03 / 2011$ & Enchente/Inundação & Rotatória do Cristo & $\begin{array}{l}\text { São Carlos } \\
\text { Agora } \\
\end{array}$ & 199373 & 7562411 \\
\hline $12 / 03 / 2011$ & Enchente/Inundação & $\begin{array}{c}\text { Rotatória da Educativa na Avenida Comendador } \\
\text { Alfredo Maffei } \\
\end{array}$ & $\begin{array}{l}\text { São Carlos } \\
\text { Agora }\end{array}$ & 203570 & 7561431 \\
\hline $27 / 03 / 2011$ & Enchente/Inundação & Rotatória do Cristo & Defesa Civil & 199373 & 7562411 \\
\hline $28 / 03 / 2011$ & Colapso de solo & Rua Jose Texeira 68 & Defesa Civil & 198625 & 7563354 \\
\hline $30 / 03 / 2011$ & Colapso de solo & Avenida Republica do Líbano 768 & Defesa Civil & 201625 & 7559603 \\
\hline $28 / 04 / 2011$ & Movimento de encosta & Avenida Integração & Defesa Civil & 200738 & 7558836 \\
\hline $18 / 05 / 2011$ & Erosão & $\begin{array}{c}\text { Rua Marcolino Lopes Barreto na ponte do Tijuco Preto } \\
\text { ( problema recorrente) }\end{array}$ & $\begin{array}{c}\text { São Carlos } \\
\text { Agora }\end{array}$ & 202507 & 7561848 \\
\hline 28/07/2011 & Colapso de solo & Rua Felipe Beltrami 215 & Defesa Civil & 201844 & 7559759 \\
\hline $29 / 08 / 2011$ & Colapso de solo & Avenida Paulo VI 1449 & Defesa Civil & 201066 & 7558684 \\
\hline $07 / 09 / 2011$ & Movimento de encosta & - & Mosaico & 200888 & 7559353 \\
\hline 07/09/2011 & Movimento de encosta & - & Mosaico & 200850 & 7559365 \\
\hline $22 / 11 / 2011$ & Colapso de solo & Rua Roberto de Jesus Afonso 960 & Defesa Civil & 199403 & 7564071 \\
\hline $07 / 12 / 2011$ & Alagamento & Praça Itália & Defesa Civil & 201636 & 7560747 \\
\hline $07 / 12 / 2011$ & Movimento de encosta & Serra de Aracy & Defesa Civil & 200738 & 7558836 \\
\hline $23 / 12 / 2011$ & Colapso de solo & Rua Madre Tereza de Calcutá 287 & Defesa Civil & 199516 & 7564915 \\
\hline $27 / 12 / 2011$ & Colapso de solo & Rua Visconde da Cunha 75 & Defesa Civil & 203903 & 7561396 \\
\hline $31 / 12 / 2011$ & Enchente/Inundação & Rotatória do Cristo & Defesa Civil & 199373 & 7562411 \\
\hline
\end{tabular}




\begin{tabular}{|c|c|c|c|c|c|}
\hline \multirow{2}{*}{ Data } & \multirow{2}{*}{ Eventos } & \multirow{2}{*}{ Local } & \multirow{2}{*}{ Fonte } & \multicolumn{2}{|c|}{ CA23S } \\
\hline & & & & $\mathbf{X}$ & $\mathbf{Y}$ \\
\hline $31 / 12 / 2011$ & Enchente/Inundação & Avenida Francisco Pereira Lopes & Defesa Civil & 199504 & 7562540 \\
\hline $31 / 12 / 2011$ & Alagamento & $\mathrm{CDHU}$ & Defesa Civil & 202315 & 7560180 \\
\hline $31 / 12 / 2011$ & Alagamento & Praça Itália & $\begin{array}{l}\text { São Carlos } \\
\text { Agora }\end{array}$ & 201636 & 7560747 \\
\hline $31 / 12 / 2011$ & Movimento de encosta & Avenida Integração & Defesa Civil & 200738 & 7558836 \\
\hline $23 / 01 / 2012$ & Alagamento & Avenida Getulio Vargas & Defesa Civil & 203603 & 7560549 \\
\hline $23 / 01 / 2012$ & Alagamento & Rua santa Gertrudes & Defesa Civil & 202372 & 7560270 \\
\hline $23 / 01 / 2012$ & Alagamento & Praça Itália & Defesa Civil & 201636 & 7560747 \\
\hline $23 / 01 / 2012$ & Alagamento & Rua Itália (Travessa 8) & Defesa Civil & 201352 & 7561124 \\
\hline $23 / 01 / 2012$ & Enchente/Inundação & Rua Geminiano Costa (Região Central) & Defesa Civil & 201552 & 7562066 \\
\hline $23 / 01 / 2012$ & Enchente/Inundação & Baixada do Mercado & $\begin{array}{l}\text { São Carlos } \\
\text { Agora }\end{array}$ & 201551 & 7562083 \\
\hline 23/01/2012 & Enchente/Inundação & Rotatória do Cristo & $\begin{array}{l}\text { São Carlos } \\
\text { Agora }\end{array}$ & 199373 & 7562411 \\
\hline $01 / 03 / 2012$ & Enchente/Inundação & Rotatória do Cristo & Defesa Civil & 199373 & 7562411 \\
\hline $01 / 03 / 2012$ & Alagamento & Rua Luis Barbosa de Campos 284 & Defesa Civil & 199896 & 7563360 \\
\hline $08 / 03 / 2012$ & Colapso de solo & Rua Jose Barnabé 87 & Defesa Civil & 203006 & 7560976 \\
\hline $20 / 03 / 2012$ & Colapso de solo & Rua Raimundo Correa 1900 & Defesa Civil & 203424 & 7560646 \\
\hline $07 / 08 / 2012$ & Colapso de solo & Rua Antonio Botelho 75 & Defesa Civil & 201140 & 7561392 \\
\hline $13 / 08 / 2012$ & Colapso de solo & Rua Manoel Martins 654 & Defesa Civil & 204879 & 7564200 \\
\hline $24 / 10 / 2012$ & Erosão & Rua Rui Barbosa com José Rodrigues Sampaio & Defesa Civil & 202031 & 7561578 \\
\hline $03 / 11 / 2012$ & Enchente/Inundação & Rotatória do Cristo & $\begin{array}{l}\text { São Carlos } \\
\text { Agora }\end{array}$ & 199373 & 7562411 \\
\hline $05 / 11 / 2012$ & Alagamento & $\mathrm{CDHU}$ & Defesa Civil & 202315 & 7560180 \\
\hline $05 / 11 / 2012$ & Alagamento & Praça Itália & Defesa Civil & 201636 & 7560747 \\
\hline $25 / 11 / 2012$ & Alagamento & Rua Bento Carlos 1498 & Defesa Civil & 202699 & 7561910 \\
\hline $25 / 11 / 2012$ & Alagamento & Avenida Capitão Luiz Brandão 1677 & Defesa Civil & 204239 & 7564723 \\
\hline $02 / 12 / 2012$ & Erosão & Avenida Dr Jose Pereira Lopes 1346 & Defesa Civil & 199493 & 7561474 \\
\hline $09 / 12 / 2012$ & Enchente/Inundação & Rotatória do Cristo & Defesa Civil & 199373 & 7562411 \\
\hline $09 / 12 / 2012$ & Enchente/Inundação & Tancredo Neves Rotatória Engefort & Defesa Civil & 199254 & 7562247 \\
\hline 09/12/2012 & Enchente/Inundação & Kartódromo & $\begin{array}{c}\text { São Carlos } \\
\text { Agora }\end{array}$ & 200600 & 7564344 \\
\hline $09 / 12 / 2012$ & Enchente/Inundação & Avenida Eliza Gonzales Rabello & $\begin{array}{l}\text { São Carlos } \\
\text { Agora }\end{array}$ & 200600 & 7564344 \\
\hline $09 / 12 / 2012$ & Enchente/Inundação & $\begin{array}{c}\text { Avenida Francisco Pereira Lopes, na região do } \\
\text { Restaurante Casa Branca }\end{array}$ & $\begin{array}{c}\text { São Carlos } \\
\text { Agora }\end{array}$ & 200039 & 7563305 \\
\hline $12 / 01 / 2013$ & Enchente/Inundação & Rotatória do Cristo & $\begin{array}{l}\text { São Carlos } \\
\text { Agora }\end{array}$ & 199373 & 7562411 \\
\hline $12 / 01 / 2013$ & Enchente/Inundação & Kartódromo & $\begin{array}{l}\text { São Carlos } \\
\text { Agora }\end{array}$ & 200600 & 7564344 \\
\hline $22 / 02 / 2013$ & Enchente/Inundação & Kartódromo & $\begin{array}{l}\text { São Carlos } \\
\text { Agora }\end{array}$ & 200600 & 7564344 \\
\hline $22 / 02 / 2013$ & Enchente/Inundação & Rotatória do Cristo & RegiaoDestake & 199373 & 7562411 \\
\hline $22 / 02 / 2013$ & Alagamento & $\mathrm{CDHU}$ & RegiaoDestake & 202315 & 7560180 \\
\hline $22 / 02 / 2013$ & Enchente/Inundação & $\begin{array}{l}\text { Cruzamento da Avenida Comendador Alfredo Maffei } \\
\text { com a Rua Dom Pedro II }\end{array}$ & RegiaoDestake & 201913 & 7562086 \\
\hline $22 / 02 / 2013$ & Enchente/Inundação & $\begin{array}{c}\text { Trabalhador São Carlense com Francisco Pereira Lopes } \\
\text { próximo a Usp }\end{array}$ & RegiaoDestake & 200603 & 7564090 \\
\hline $22 / 02 / 2013$ & Erosão & $\begin{array}{c}\text { Rua Geminiano Costa, entre as ruas Dom Pedro } 2 \text { e a } \\
\text { Rui Barbosa, (rua cedeu) }\end{array}$ & $\begin{array}{l}\text { São Carlos } \\
\text { Agora }\end{array}$ & 201966 & 7562075 \\
\hline $25 / 02 / 2013$ & Alagamento & Praça Itália & $\begin{array}{l}\text { São Carlos Dia } \\
\text { e Noite }\end{array}$ & 201636 & 7560747 \\
\hline $25 / 02 / 2013$ & Alagamento & $\mathrm{CDHU}$ & $\begin{array}{c}\text { São Carlos Dia } \\
\text { e Noite }\end{array}$ & 202315 & 7560180 \\
\hline $25 / 02 / 2013$ & Alagamento & Avenida Getúlio Vargas próximo a empresa Latina & $\begin{array}{c}\text { São Carlos Dia } \\
\text { e Noite }\end{array}$ & 204221 & 7560466 \\
\hline $28 / 02 / 2013$ & Enchente/Inundação & Rotatória da Educativa na Avenida Comendador & São Carlos & 203570 & 7561431 \\
\hline
\end{tabular}




\begin{tabular}{|c|c|c|c|c|c|}
\hline \multirow{2}{*}{ Data } & \multirow{2}{*}{ Eventos } & \multirow{2}{*}{ Local } & \multirow{2}{*}{ Fonte } & \multicolumn{2}{|c|}{ CA23S } \\
\hline & & & & $\mathbf{X}$ & $\mathbf{Y}$ \\
\hline & & Alfredo Maffei & Agora & & \\
\hline 09/03/2013 & Alagamento & Avenida Getúlio Vargas & RegiaoDestake & 203603 & 7560549 \\
\hline 09/03/2013 & Alagamento & Praça Itália & RegiaoDestake & 201636 & 7560747 \\
\hline $25 / 03 / 2013$ & Enchente/Inundação & Região da Baixada do Mercado (Rua Episcopal ) & $\begin{array}{c}\text { Primeira } \\
\text { Pagina }\end{array}$ & 201500 & 7562089 \\
\hline $25 / 03 / 2013$ & Alagamento & Avenida Getúlio Vargas próximo a empresa Latina & $\begin{array}{c}\text { Primeira } \\
\text { Pagina }\end{array}$ & 204221 & 7560466 \\
\hline 25/03/2013 & Enchente/Inundação & $\begin{array}{l}\text { Região da Baixada do Mercado (Avenida Comendador } \\
\text { Alfredo Maffei ) }\end{array}$ & $\begin{array}{c}\text { Primeira } \\
\text { Pagina }\end{array}$ & 201448 & 7562098 \\
\hline $25 / 03 / 2013$ & Alagamento & Praça Itália & $\begin{array}{c}\text { São Carlos } \\
\text { Agora }\end{array}$ & 201636 & 7560747 \\
\hline $25 / 03 / 2013$ & Enchente/Inundação & Rotatória do Cristo & $\begin{array}{l}\text { São Carlos } \\
\text { Agora }\end{array}$ & 199373 & 7562411 \\
\hline $25 / 03 / 2013$ & Alagamento & $\mathrm{CDHU}$ & $\begin{array}{l}\text { São Carlos } \\
\text { Agora }\end{array}$ & 202315 & 7560180 \\
\hline 03/04/2013 & Enchente/Inundação & $\begin{array}{c}\text { Rotatória da Educativa na Avenida Comendador } \\
\text { Alfredo Maffei }\end{array}$ & $\begin{array}{l}\text { São Carlos } \\
\text { Agora }\end{array}$ & 203570 & 7561431 \\
\hline 03/04/2013 & Alagamento & CDHU & $\begin{array}{l}\text { São Carlos } \\
\text { Agora }\end{array}$ & 202315 & 7560180 \\
\hline 03/04/2013 & Alagamento & Praça Itália & $\begin{array}{l}\text { São Carlos } \\
\text { Agora }\end{array}$ & 201636 & 7560747 \\
\hline 03/04/2013 & Alagamento & Pontilhão da Travessa 8 & $\begin{array}{l}\text { São Carlos } \\
\text { Agora }\end{array}$ & 201352 & 7561124 \\
\hline $03 / 04 / 2013$ & Alagamento & Avenida Getúlio Vargas próximo a empresa Latina & $\begin{array}{l}\text { São Carlos } \\
\text { Agora }\end{array}$ & 204221 & 7560466 \\
\hline $03 / 04 / 2013$ & Alagamento & $\begin{array}{c}\text { Rotatória do posto de combustíveis do Maria Stella } \\
\text { Faga }\end{array}$ & $\begin{array}{l}\text { São Carlos } \\
\text { Agora }\end{array}$ & 205039 & 7563567 \\
\hline $08 / 04 / 2013$ & Erosão & $\begin{array}{c}\text { Comendador Alfredo Maffei entre as ruas Dom Pedro } 2 \\
\text { e São Joaquim (rachaduras no asfalto) }\end{array}$ & $\begin{array}{c}\text { São Carlos } \\
\text { Agora }\end{array}$ & 201861 & 7562085 \\
\hline $28 / 05 / 2013$ & Alagamento & Rua Coronel Leopoldo Prado, linha férrea & $\begin{array}{l}\text { São Carlos Dia } \\
\text { e Noite }\end{array}$ & 201566 & 7560735 \\
\hline 28/05/2013 & Erosão & $\begin{array}{l}\text { Avenida Comendador Alfredo Maffei entre as ruas } \\
\text { D.Pedro II e São Joaquim no sentido Fórum Cível para } \\
\text { a avenida }\end{array}$ & $\begin{array}{l}\text { São Carlos Dia } \\
\text { e Noite }\end{array}$ & 201861 & 7562085 \\
\hline $29 / 05 / 2013$ & Alagamento & CDHU & $\begin{array}{l}\text { São Carlos } \\
\text { Agora }\end{array}$ & 202315 & 7560180 \\
\hline $24 / 08 / 2013$ & Erosão & $\begin{array}{l}\text { Erosão na base do lado noroeste da Chaminé da fabrica } \\
\text { de cola e adubo Facchina }\end{array}$ & RegiaoDestake & 202391 & 7561919 \\
\hline $12 / 10 / 2013$ & Movimento de encosta & - & Mosaico & 200871 & 7559821 \\
\hline $12 / 10 / 2013$ & Movimento de encosta & - & Mosaico & 201459 & 7558591 \\
\hline $22 / 10 / 2013$ & Enchente/Inundação & Rotatória do Cristo & EPTV & 199373 & 7562411 \\
\hline $22 / 10 / 2013$ & Enchente/Inundação & Baixada do Mercado & EPTV & 201551 & 7562083 \\
\hline $22 / 10 / 2013$ & Enchente/Inundação & Baixada do Mercado & EPTV & 201448 & 7562098 \\
\hline $22 / 10 / 2013$ & Alagamento & $\mathrm{CDHU}$ & EPTV & 202315 & 7560180 \\
\hline $22 / 10 / 2013$ & Enchente/Inundação & $\begin{array}{c}\text { Rotatória da Educativa na Avenida Comendador } \\
\text { Alfredo Maffei }\end{array}$ & $\begin{array}{l}\text { São Carlos } \\
\text { Agora }\end{array}$ & 203570 & 7561431 \\
\hline $04 / 11 / 2013$ & Enchente/Inundação & Rotatória do Cristo & $\begin{array}{c}\text { São Carlos } \\
\text { Agora }\end{array}$ & 199373 & 7562411 \\
\hline $04 / 11 / 2013$ & Enchente/Inundação & $\begin{array}{c}\text { Rotatória entre as ruas Jose Bonifácio e Jesuíno de } \\
\text { Arruda }\end{array}$ & $\begin{array}{l}\text { São Carlos } \\
\text { Agora }\end{array}$ & 201288 & 7562165 \\
\hline $03 / 12 / 2013$ & Erosão & $\begin{array}{l}\text { Travessia para pedestres no Córrego Santa Maria do } \\
\text { Leme, localizado na Rua Benedita Stall Sodré, esquina } \\
\text { com a Rua Brás Cubas, no Jardim Hikare }\end{array}$ & $\begin{array}{l}\text { São Carlos Dia } \\
\text { e Noite }\end{array}$ & 200246 & 7564911 \\
\hline $31 / 12 / 2013$ & Enchente/Inundação & Rotatória do Cristo & $\begin{array}{l}\text { São Carlos } \\
\text { Agora }\end{array}$ & 199373 & 7562411 \\
\hline 07/01/2014 & Erosão & Jardim Novo Horizonte na rua Miguel Ruggiero & $\begin{array}{c}\text { São Carlos } \\
\text { Agora }\end{array}$ & 204953 & 7560007 \\
\hline $23 / 01 / 2014$ & Erosão & $\begin{array}{c}\text { Rua General Osório próximo à Rua Eugênio Franco de } \\
\text { Camargo, no Jardim Cardinalli. }\end{array}$ & $\begin{array}{l}\text { São Carlos Dia } \\
\text { e Noite }\end{array}$ & 202933 & 7562016 \\
\hline $11 / 02 / 2014$ & Erosão & Rotatória do Cristo & $\begin{array}{c}\text { Primeira } \\
\text { Pagina } \\
\end{array}$ & 199373 & 7562411 \\
\hline $09 / 05 / 2014$ & Movimento de encosta & - & Mosaico & 196277 & 7560964 \\
\hline $09 / 05 / 2014$ & Movimento de encosta & - & Mosaico & 196362 & 7561078 \\
\hline 09/05/2014 & Erosão & - & Mosaico & 200709 & 7558615 \\
\hline
\end{tabular}




\begin{tabular}{|c|c|c|c|c|c|}
\hline \multirow{2}{*}{ Data } & \multirow{2}{*}{ Eventos } & \multirow{2}{*}{ Local } & \multirow{2}{*}{ Fonte } & \multicolumn{2}{|c|}{ CA23S } \\
\hline & & & & $\mathbf{X}$ & $\mathbf{Y}$ \\
\hline 09/05/2014 & Erosão & - & Mosaico & 205771 & 7558863 \\
\hline 09/05/2014 & Erosão & - & Mosaico & 201634 & 7557975 \\
\hline 09/05/2014 & Erosão & - & Mosaico & 201788 & 7557934 \\
\hline 09/05/2014 & Erosão & - & Mosaico & 201359 & 7558362 \\
\hline $09 / 05 / 2014$ & Erosão & - & Mosaico & 199849 & 7558506 \\
\hline 09/05/2014 & Erosão & - & Mosaico & 201898 & 7557641 \\
\hline $09 / 05 / 2014$ & Erosão & - & Mosaico & 202716 & 7557412 \\
\hline 09/05/2014 & Erosão & - & Mosaico & 205892 & 7556708 \\
\hline 08/09/2014 & Movimento de encosta & - & Mosaico & 200245 & 7559400 \\
\hline $25 / 02 / 2015$ & Enchente/Inundação & Rotatória do Cristo & RegiaoDestake & 199373 & 7562411 \\
\hline $27 / 02 / 2015$ & Enchente/Inundação & Avenida São Carlos na região do União Serv. & $\begin{array}{c}\text { São Carlos Dia } \\
\text { e Noite }\end{array}$ & 201538 & 7563831 \\
\hline $11 / 03 / 2015$ & Enchente/Inundação & Avenida São Carlos na região do União Serv. & $\begin{array}{c}\text { Primeira } \\
\text { Pagina } \\
\end{array}$ & 201538 & 7563831 \\
\hline $11 / 03 / 2015$ & Enchente/Inundação & $\begin{array}{c}\text { Cruzamento das Avenidas Liberdade e Elisa Gonzales } \\
\text { Rabelo (Parque do Kartódromo); }\end{array}$ & $\begin{array}{c}\text { Primeira } \\
\text { Pagina }\end{array}$ & 200600 & 7564344 \\
\hline $16 / 03 / 2015$ & Enchente/Inundação & Calçadão da General Osório (Baxada do Mercado) & $\begin{array}{c}\text { São Carlos } \\
\text { Agora }\end{array}$ & 201558 & 7561962 \\
\hline 28/03/2015 & Enchente/Inundação & Kartódromo & $\begin{array}{c}\text { Primeira } \\
\text { Pagina }\end{array}$ & 200600 & 7564344 \\
\hline 28/03/2015 & Enchente/Inundação & Rotatória do Cristo & $\begin{array}{c}\text { Primeira } \\
\text { Pagina }\end{array}$ & 199373 & 7562411 \\
\hline $05 / 06 / 2015$ & Alagamento & $\begin{array}{c}\text { Benjamim Lopes Osores, no condomínio Tecumseh } \\
\text { Village }\end{array}$ & $\begin{array}{c}\text { São Carlos Dia } \\
\text { e Noite }\end{array}$ & 205564 & 7564125 \\
\hline $08 / 09 / 2015$ & Alagamento & Rua João Martins França na Cidade Aracy & $\begin{array}{c}\text { Primeira } \\
\text { Pagina } \\
\end{array}$ & 199702 & 7557760 \\
\hline $04 / 11 / 2015$ & Alagamento & Rua João Martins França, Cidade Aracy 2 & $\begin{array}{c}\text { São Carlos } \\
\text { Agora }\end{array}$ & 199702 & 7557760 \\
\hline $04 / 11 / 2015$ & Alagamento & Rua santa Gertrudes (sentido rotatória do CDHU) & $\begin{array}{c}\text { Primeira } \\
\text { Pagina } \\
\end{array}$ & 202372 & 7560270 \\
\hline $04 / 11 / 2015$ & Alagamento & Rua João Martins França na Cidade Aracy & $\begin{array}{c}\text { Primeira } \\
\text { Pagina } \\
\end{array}$ & 199702 & 7557760 \\
\hline $04 / 11 / 2015$ & Alagamento & $\mathrm{CDHU}$ & $\begin{array}{c}\text { Primeira } \\
\text { Pagina }\end{array}$ & 202315 & 7560180 \\
\hline $17 / 11 / 2015$ & Alagamento & Rua santa Gertrudes (sentido rotatória do CDHU) & $\begin{array}{c}\text { São Carlos Dia } \\
\text { e Noite }\end{array}$ & 202372 & 7560270 \\
\hline $23 / 11 / 2015$ & Enchente/Inundação & Avenida Trabalhador São Carlense & $\begin{array}{l}\text { Primeira } \\
\text { Pagina }\end{array}$ & 200603 & 7564090 \\
\hline $23 / 11 / 2015$ & Enchente/Inundação & $\begin{array}{c}\text { Baixada do Mercado (9 de Julho com Comendador } \\
\text { Alfredo Maffei) }\end{array}$ & $\begin{array}{c}\text { Primeira } \\
\text { Pagina } \\
\end{array}$ & 201398 & 7562095 \\
\hline $23 / 11 / 2015$ & Enchente/Inundação & Baixada do Mercado (Geminiado Costa com Episcopal) & $\begin{array}{c}\text { Primeira } \\
\text { Pagina } \\
\end{array}$ & 201499 & 7562061 \\
\hline $23 / 11 / 2015$ & Enchente/Inundação & $\begin{array}{c}\text { Baixada do Mercado (Comendador Alfredo Maffei com } \\
\text { Geminiano Costa) }\end{array}$ & $\begin{array}{c}\text { Primeira } \\
\text { Pagina } \\
\end{array}$ & 201807 & 7562078 \\
\hline $23 / 11 / 2015$ & Alagamento & Praça Itália & $\begin{array}{c}\text { Primeira } \\
\text { Pagina } \\
\end{array}$ & 201636 & 7560747 \\
\hline $23 / 11 / 2015$ & Alagamento & Rua Raimundo Correa & $\begin{array}{c}\text { Primeira } \\
\text { Pagina } \\
\end{array}$ & 202658 & 7561089 \\
\hline $23 / 11 / 2015$ & Enchente/Inundação & Rotatória do Cristo & $\begin{array}{c}\text { Primeira } \\
\text { Pagina } \\
\end{array}$ & 199373 & 7562411 \\
\hline $23 / 11 / 2015$ & Enchente/Inundação & Kartódromo & $\begin{array}{l}\text { Primeira } \\
\text { Pagina }\end{array}$ & 200600 & 7564344 \\
\hline $23 / 11 / 2015$ & Enchente/Inundação & Região da Rodoviária & $\begin{array}{c}\text { Primeira } \\
\text { Pagina }\end{array}$ & 201688 & 7563868 \\
\hline $23 / 11 / 2015$ & Enchente/Inundação & Rua Dona Alexandrina & A Folha & 201707 & 7562085 \\
\hline $23 / 11 / 2015$ & Enchente/Inundação & Rua São Joaquim & A Folha & 201807 & 7562078 \\
\hline 23/11/2015 & Enchente/Inundação & Parque do Bicão & A Folha & 199917 & 7560872 \\
\hline $23 / 11 / 2015$ & Alagamento & $\mathrm{CDHU}$ & \begin{tabular}{|c|} 
Revelando São \\
Carlos
\end{tabular} & 202315 & 7560180 \\
\hline $23 / 11 / 2015$ & Enchente/Inundação & $\begin{array}{c}\text { Avenida Francisco Pereira Lopes, na região do } \\
\text { Restaurante Casa Branca }\end{array}$ & $\begin{array}{c}\begin{array}{c}\text { Revelando São } \\
\text { Carlos }\end{array} \\
\end{array}$ & 200039 & 7563305 \\
\hline $08 / 12 / 2015$ & Erosão & Avenida Francisco Pereira Lopes, Curva do Joinha & $\begin{array}{c}\text { Primeira } \\
\text { Pagina }\end{array}$ & 200243 & 7563440 \\
\hline
\end{tabular}




\begin{tabular}{|c|c|c|c|c|c|}
\hline \multirow{2}{*}{ Data } & \multirow{2}{*}{ Eventos } & \multirow{2}{*}{ Local } & \multirow{2}{*}{ Fonte } & \multicolumn{2}{|c|}{ CA23S } \\
\hline & & & & $\mathbf{X}$ & $\mathbf{Y}$ \\
\hline $10 / 12 / 2015$ & Alagamento & Rua João Martins França na Cidade Aracy & $\begin{array}{l}\text { São Carlos Em } \\
\text { Rede }\end{array}$ & 199702 & 7557760 \\
\hline $10 / 12 / 2015$ & Alagamento & Rua Raimundo Correia & EPTV & 202658 & 7561089 \\
\hline $10 / 01 / 2016$ & Alagamento & Rua santa Gertrudes (sentido Rotatória do CDHU) & $\begin{array}{l}\text { São Carlos Em } \\
\text { Rede }\end{array}$ & 202372 & 7560270 \\
\hline $10 / 01 / 2016$ & Enchente/Inundação & $\begin{array}{c}\text { Rotatória da Educativa na Avenida Comendador } \\
\text { Alfredo Maffei }\end{array}$ & $\begin{array}{l}\text { São Carlos Em } \\
\text { Rede }\end{array}$ & 203570 & 7561431 \\
\hline $12 / 01 / 2016$ & Enchente/Inundação & Rotatória do Cristo & RegiaoDestake & 199373 & 7562411 \\
\hline $12 / 01 / 2016$ & Erosão & Rotatória do Cristo & $\begin{array}{l}\text { São Carlos Dia } \\
\text { e Noite }\end{array}$ & 199373 & 7562411 \\
\hline $13 / 01 / 2016$ & Enchente/Inundação & Parque Ecológico & $\begin{array}{l}\text { Revelando São } \\
\text { Carlos }\end{array}$ & 202971 & 7565879 \\
\hline $13 / 01 / 2016$ & Erosão & $\begin{array}{c}\text { Margem do Gregório, nas proximidades do número } 45 \\
\text { da Avenida Maria Consuelo Brandão Tolentino }\end{array}$ & $\begin{array}{l}\text { Revelando São } \\
\text { Carlos }\end{array}$ & 199371 & 7561320 \\
\hline $25 / 01 / 2016$ & Enchente/Inundação & Parque do Bicão & $\begin{array}{l}\text { São Carlos } \\
\text { Agora }\end{array}$ & 199917 & 7560872 \\
\hline $25 / 01 / 2016$ & Alagamento & Rua Jose Bonifacio próximo a antiga Fabber & $\begin{array}{l}\text { São Carlos } \\
\text { Agora }\end{array}$ & 201271 & 7562670 \\
\hline $25 / 01 / 2016$ & Enchente/Inundação & Rotatória do Cristo & $\begin{array}{l}\text { São Carlos } \\
\text { Agora }\end{array}$ & 199373 & 7562411 \\
\hline $18 / 02 / 2016$ & Alagamento & Bairro Lagoa Serena & $\begin{array}{l}\text { São Carlos Em } \\
\text { Rede }\end{array}$ & 201442 & 7561418 \\
\hline $18 / 02 / 2016$ & Alagamento & Praça Itália & $\begin{array}{l}\text { São Carlos Em } \\
\text { Rede }\end{array}$ & 201636 & 7560747 \\
\hline $23 / 03 / 2016$ & Alagamento & Região do Jardim Dona Francisca & $\begin{array}{l}\text { São Carlos Em } \\
\text { Rede }\end{array}$ & 203756 & 7560916 \\
\hline $23 / 03 / 2016$ & Enchente/Inundação & Região da Rodoviária & EPTV & 201688 & 7563868 \\
\hline $09 / 04 / 2016$ & Erosão & - & Mosaico & 197313 & 7567636 \\
\hline $09 / 04 / 2016$ & Erosão & - & Mosaico & 195781 & 7567442 \\
\hline $09 / 04 / 2016$ & Erosão & - & Mosaico & 303259 & 7566801 \\
\hline $09 / 04 / 2016$ & Erosão & - & Mosaico & 197015 & 7566258 \\
\hline $09 / 04 / 2016$ & Erosão & - & Mosaico & 196296 & 7566600 \\
\hline $09 / 04 / 2016$ & Erosão & - & Mosaico & 199440 & 7565391 \\
\hline $09 / 04 / 2016$ & Erosão & - & Mosaico & 199703 & 7565902 \\
\hline $09 / 04 / 2016$ & Erosão & - & Mosaico & 206254 & 7562658 \\
\hline 09/04/2016 & Erosão & - & Mosaico & 203457 & 7562379 \\
\hline 09/04/2016 & Erosão & - & Mosaico & 198988 & 7560772 \\
\hline $09 / 04 / 2016$ & Erosão & - & Mosaico & 196980 & 7560695 \\
\hline $09 / 04 / 2016$ & Erosão & - & Mosaico & 205053 & 7559209 \\
\hline $09 / 04 / 2016$ & Erosão & - & Mosaico & 200041 & 7559542 \\
\hline $09 / 04 / 2016$ & Erosão & - & Mosaico & 197819 & 7558617 \\
\hline 09/04/2016 & Erosão & - & Mosaico & 197886 & 7558560 \\
\hline $09 / 04 / 2016$ & Erosão & - & Mosaico & 200624 & 7558566 \\
\hline $16 / 05 / 2016$ & Enchente/Inundação & $\begin{array}{c}\text { Avenida Francisco Pereira Lopes, na região do } \\
\text { Restaurante Casa Branca }\end{array}$ & $\begin{array}{l}\text { São Carlos Em } \\
\text { Rede }\end{array}$ & 200039 & 7563305 \\
\hline 05/06/2016 & Alagamento & Rua João Martins França, Cidade Aracy 2 & $\begin{array}{l}\text { São Carlos } \\
\text { Agora }\end{array}$ & 199702 & 7557760 \\
\hline
\end{tabular}


APÊNDICE B - Mapa de documentação 


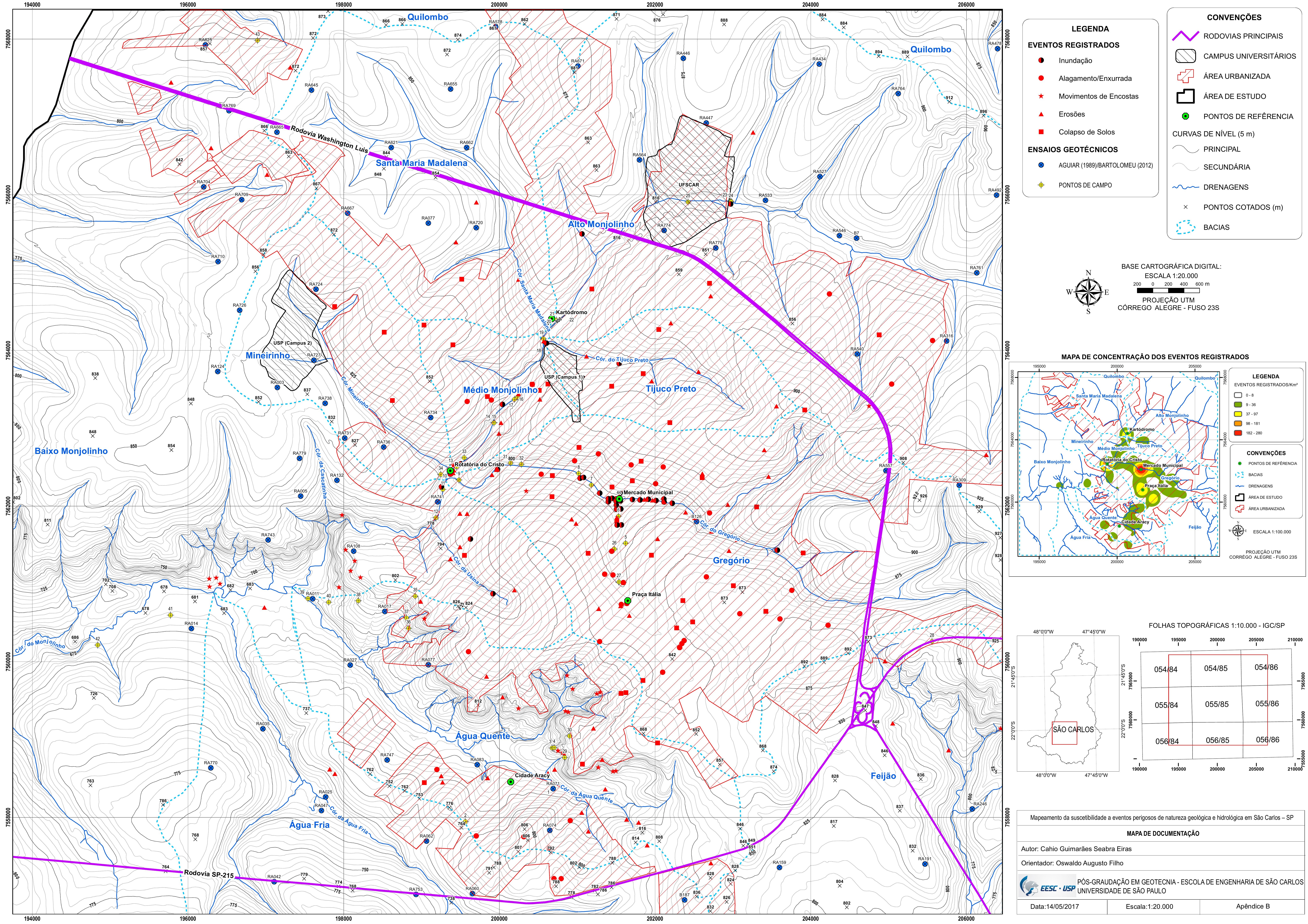


APÊNDICE C - Classes de Terreno 



\begin{tabular}{|c|c|c|}
\hline Gridcode & Classe de Terreno (Uso e ocupação - compartimento geotécnico - encosta - declividade em \%) & Área $\left(\mathbf{m}^{2}\right)$ \\
\hline 1111 & Agricultura - Coluvionar - Coletora - 0 a 5 & 599,4 \\
\hline 1112 & Agricultura - Coluvionar - Coletora - 5 a 10 & 11062,6 \\
\hline 1113 & Agricultura - Coluvionar - Coletora - 10 a 18 & 45694,1 \\
\hline 1114 & Agricultura - Coluvionar - Coletora - 18 a 33 & 5356,0 \\
\hline 1121 & Agricultura - Coluvionar - Plana - 0 a 5 & 50,0 \\
\hline 1122 & Agricultura - Coluvionar - Plana - 5 a 10 & 1732,1 \\
\hline 1123 & Agricultura - Coluvionar - Plana - 10 a 18 & 5914,8 \\
\hline 1124 & Agricultura - Coluvionar - Plana - 18 a 33 & 291,0 \\
\hline 1131 & Agricultura - Coluvionar - Dispersora - 0 a 5 & 175,0 \\
\hline 1132 & Agricultura - Coluvionar - Dispersora - 5 a 10 & 26474,5 \\
\hline 1133 & Agricultura - Coluvionar - Dispersora - 10 a 18 & 93002,1 \\
\hline 1134 & Agricultura - Coluvionar - Dispersora - 10 a 18 & 6194,6 \\
\hline 1211 & Agricultura - Aluvionar - Coletora - 0 a 5 & 25,0 \\
\hline 1212 & Agricultura - Aluvionar - Coletora - 5 a 10 & 1525,0 \\
\hline 1213 & Agricultura - Aluvionar - Coletora - 10 a 18 & 756,9 \\
\hline 1222 & Agricultura - Aluvionar - Plana - 5 a 10 & 184,9 \\
\hline 1223 & Agricultura - Aluvionar - Plana - 10 a 18 & 50,0 \\
\hline 1231 & Agricultura - Aluvionar - Dispersora - 0 a 5 & 25,0 \\
\hline 1232 & Agricultura - Aluvionar - Dispersora - 5 a 10 & 2114,0 \\
\hline 1233 & Agricultura - Aluvionar - Dispersora - 10 a 18 & 921,8 \\
\hline 1234 & Agricultura - Aluvionar - Dispersora - 18 a 33 & 686,2 \\
\hline 1311 & Agricultura - Itaqueri - Coletora - 0 a 5 & 3343267,2 \\
\hline 1312 & Agricultura - Itaqueri - Coletora - 5 a 10 & 3546814,2 \\
\hline 1313 & Agricultura - Itaqueri - Coletora - 10 a 18 & 1354050,4 \\
\hline 1314 & Agricultura - Itaqueri - Coletora - 18 a 33 & 116670,7 \\
\hline 1315 & Agricultura - Itaqueri - Coletora - > 33 & 10676,2 \\
\hline 1321 & Agricultura - Itaqueri - Plana - 0 a 5 & 2903718,4 \\
\hline 1322 & Agricultura - Itaqueri - Plana - 5 a 10 & 851208,2 \\
\hline 1323 & Agricultura - Itaqueri - Plana - 10 a 18 & 130584,3 \\
\hline 1324 & Agricultura - Itaqueri - Plana - 18 a 33 & 4737,4 \\
\hline 1325 & Agricultura - Itaqueri - Plana - > 33 & 430,0 \\
\hline 1331 & Agricultura - Itaqueri - Dispersora - 0 a 5 & 7348679,1 \\
\hline 1332 & Agricultura - Itaqueri - Dispersora - 5 a 10 & 4890918,6 \\
\hline 1333 & Agricultura - Itaqueri - Dispersora - 10 a 18 & 1652146,7 \\
\hline 1334 & Agricultura - Itaqueri - Dispersora - 18 a 33 & 163865,8 \\
\hline 1335 & Agricultura - Itaqueri - Dispersora - > 33 & 12670,4 \\
\hline 1413 & Agricultura -Serra Geral - Coletora - 10 a 18 & 11964,9 \\
\hline 1414 & Agricultura -Serra Geral - Coletora - 18 a 33 & 19730,3 \\
\hline 1415 & Agricultura -Serra Geral - Coletora - > 33 & 25824,8 \\
\hline 1423 & Agricultura -Serra Geral - Plana - 10 a 18 & 373,9 \\
\hline 1424 & Agricultura -Serra Geral - Plana - 18 a 33 & 482,0 \\
\hline 1425 & Agricultura -Serra Geral - Plana - > 33 & 639,9 \\
\hline 1432 & Agricultura -Serra Geral - Dispersora - 5 a 10 & 50,0 \\
\hline 1433 & Agricultura -Serra Geral - Dispersora - 10 a 18 & 13314,9 \\
\hline
\end{tabular}




\begin{tabular}{|c|c|c|}
\hline Gridcode & Classe de Terreno (Uso e ocupação - compartimento geotécnico - encosta - declividade em \%) & Área $\left(\mathbf{m}^{2}\right)$ \\
\hline 1434 & Agricultura -Serra Geral - Dispersora - 18 a 33 & 20633,1 \\
\hline 1435 & Agricultura -Serra Geral - Dispersora - > 33 & 38476,3 \\
\hline 1511 & Agricultura -Botucatu - Coletora - 0 a 5 & 1965661,2 \\
\hline 1512 & Agricultura -Botucatu - Coletora - 5 a 10 & 1709343,2 \\
\hline 1513 & Agricultura -Botucatu - Coletora - 10 a 18 & 641139,9 \\
\hline 1514 & Agricultura -Botucatu - Coletora - 18 a 33 & 87893,9 \\
\hline 1515 & Agricultura -Botucatu - Coletora - > 33 & 11098,2 \\
\hline 1521 & Agricultura -Botucatu - Plana - 0 a 5 & 1120273,5 \\
\hline 1522 & Agricultura -Botucatu - Plana - 5 a 10 & 446321,7 \\
\hline 1523 & Agricultura -Botucatu - Plana - 10 a 18 & 62753,4 \\
\hline 1524 & Agricultura -Botucatu - Plana - 18 a 33 & 2971,1 \\
\hline 1525 & Agricultura -Botucatu - Plana - > 33 & 66,0 \\
\hline 1531 & Agricultura -Botucatu - Dispersora - 0 a 5 & 2759746,4 \\
\hline 1532 & Agricultura -Botucatu - Dispersora - 5 a 10 & 2296804,3 \\
\hline 1533 & Agricultura -Botucatu - Dispersora - 10 a 18 & 770196,6 \\
\hline 1534 & Agricultura -Botucatu - Dispersora - 18 a 33 & 82417,5 \\
\hline 1535 & Agricultura -Botucatu - Dispersora - > 33 & 4963,2 \\
\hline 2111 & Área de expansão - Coluvionar - Coletora - 0 a 5 & 460,8 \\
\hline 2112 & Área de expansão - Coluvionar - Coletora - 5 a 10 & 34885,8 \\
\hline 2113 & Área de expansão - Coluvionar - Coletora - 10 a 18 & 66040,9 \\
\hline 2114 & Área de expansão - Coluvionar - Coletora - 18 a 33 & 5549,7 \\
\hline 2115 & Área de expansão - Coluvionar - Coletora - > 33 & 50,0 \\
\hline 2122 & Área de expansão - Coluvionar - Plana - 5 a 10 & 5970,6 \\
\hline 2123 & Área de expansão - Coluvionar - Plana - 10 a 18 & 6390,2 \\
\hline 2124 & Área de expansão - Coluvionar - Plana - 18 a 33 & 361,0 \\
\hline 2131 & Área de expansão - Coluvionar - Dispersora - 0 a 5 & 3238,2 \\
\hline 2132 & Área de expansão - Coluvionar - Dispersora - 5 a 10 & 81281,5 \\
\hline 2133 & Área de expansão - Coluvionar - Dispersora - 10 a 18 & 104894,9 \\
\hline 2134 & Área de expansão - Coluvionar - Dispersora - 18 a 33 & 6740,2 \\
\hline 2211 & Área de expansão - Aluvionar - Coletora - 0 a 5 & 102380,6 \\
\hline 2212 & Área de expansão - Aluvionar - Coletora - 5 a 10 & 47361,0 \\
\hline 2213 & Área de expansão - Aluvionar - Coletora - 10 a 18 & 22220,1 \\
\hline 2214 & Área de expansão - Aluvionar - Coletora - 18 a 33 & 4638,5 \\
\hline 2215 & Área de expansão - Aluvionar - Coletora - > 33 & 75,0 \\
\hline 2221 & Área de expansão - Aluvionar - Plana - 0 a 5 & 7006,6 \\
\hline 2222 & Área de expansão - Aluvionar - Plana - 5 a 10 & 3487,5 \\
\hline 2223 & Área de expansão - Aluvionar - Plana - 10 a 18 & 707,0 \\
\hline 2224 & Área de expansão - Aluvionar - Plana - 18 a 33 & 75,0 \\
\hline 2231 & Área de expansão - Aluvionar - Dispersora - 0 a 5 & 24964,5 \\
\hline 2232 & Área de expansão - Aluvionar - Dispersora - 5 a 10 & 23957,1 \\
\hline 2233 & Área de expansão - Aluvionar - Dispersora - 10 a 18 & 11685,7 \\
\hline 2234 & Área de expansão - Aluvionar - Dispersora - 18 a 33 & 1435,0 \\
\hline 2311 & Área de expansão - Itaqueri - Coletora - 0 a 5 & 2138397,3 \\
\hline 2312 & Área de expansão - Itaqueri - Coletora - 5 a 10 & 1824106,1 \\
\hline
\end{tabular}




\begin{tabular}{|c|c|c|}
\hline Gridcode & Classe de Terreno (Uso e ocupação - compartimento geotécnico - encosta - declividade em \%) & Área $\left(\mathbf{m}^{2}\right)$ \\
\hline 2313 & Área de expansão - Itaqueri - Coletora - 10 a 18 & 941877,6 \\
\hline 2314 & Área de expansão - Itaqueri - Coletora - 18 a 33 & 247359,9 \\
\hline 2315 & Área de expansão - Itaqueri - Coletora - > 33 & 9305,4 \\
\hline 2321 & Área de expansão - Itaqueri - Plana - 0 a 5 & 1115436,2 \\
\hline 2322 & Área de expansão - Itaqueri - Plana - 5 a 10 & 389366,7 \\
\hline 2323 & Área de expansão - Itaqueri - Plana - 10 a 18 & 80190,5 \\
\hline 2324 & Área de expansão - Itaqueri - Plana - 18 a 33 & 8279,7 \\
\hline 2325 & Área de expansão - Itaqueri - Plana - > 33 & 141,0 \\
\hline 2331 & Área de expansão - Itaqueri - Dispersora - 0 a 5 & 3320289,2 \\
\hline 2332 & Área de expansão - Itaqueri - Dispersora - 5 a 10 & 2525445,0 \\
\hline 2333 & Área de expansão - Itaqueri - Dispersora - 10 a 18 & 1220967,3 \\
\hline 2334 & Área de expansão - Itaqueri - Dispersora - 18 a 33 & 296760,7 \\
\hline 2335 & Área de expansão - Itaqueri - Dispersora - > 33 & 16334,8 \\
\hline 2411 & Área de expansão - Serra Geral - Coletora - 0 a 5 & 28266,4 \\
\hline 2412 & Área de expansão - Serra Geral - Coletora - 5 a 10 & 96328,2 \\
\hline 2413 & Área de expansão - Serra Geral - Coletora - 10 a 18 & 113920,7 \\
\hline 2414 & Área de expansão - Serra Geral - Coletora - 18 a 33 & 110331,4 \\
\hline 2415 & Área de expansão - Serra Geral - Coletora - > 33 & 38566,4 \\
\hline 2421 & Área de expansão - Serra Geral - Plana - 0 a 5 & 11876,5 \\
\hline 2422 & Área de expansão - Serra Geral - Plana - 5 a 10 & 25804,7 \\
\hline 2423 & Área de expansão - Serra Geral - Plana - 10 a 18 & 6237,0 \\
\hline 2424 & Área de expansão - Serra Geral - Plana - 18 a 33 & 2791,7 \\
\hline 2425 & Área de expansão - Serra Geral - Plana - > 33 & 817,8 \\
\hline 2431 & Área de expansão - Serra Geral - Dispersora - 0 a 5 & 99201,3 \\
\hline 2432 & Área de expansão - Serra Geral - Dispersora - 5 a 10 & 132254,7 \\
\hline 2433 & Área de expansão - Serra Geral - Dispersora - 10 a 18 & 125902,6 \\
\hline 2434 & Área de expansão - Serra Geral - Dispersora - 18 a 33 & 121222,2 \\
\hline 2435 & Área de expansão - Serra Geral - Dispersora - > 33 & 44502,7 \\
\hline 2511 & Área de expansão - Botucatu - Coletora - 0 a 5 & 1070050,8 \\
\hline 2512 & Área de expansão - Botucatu - Coletora - 5 a 10 & 1513575,0 \\
\hline 2513 & Área de expansão - Botucatu - Coletora - 10 a 18 & 971159,4 \\
\hline 2514 & Área de expansão - Botucatu - Coletora - 18 a 33 & 172912,6 \\
\hline 2515 & Área de expansão - Botucatu - Coletora - > 33 & 9589,7 \\
\hline 2521 & Área de expansão - Botucatu - Plana - 0 a 5 & 315085,3 \\
\hline 2522 & Área de expansão - Botucatu - Plana - 5 a 10 & 261359,8 \\
\hline 2523 & Área de expansão - Botucatu - Plana - 10 a 18 & 85703,8 \\
\hline 2524 & Área de expansão - Botucatu - Plana - 18 a 33 & 6240,6 \\
\hline 2525 & Área de expansão - Botucatu - Plana - > 33 & 216,0 \\
\hline 2531 & Área de expansão - Botucatu - Dispersora - 0 a 5 & 1216478,6 \\
\hline 2532 & Área de expansão - Botucatu - Dispersora - 5 a 10 & 1797063,7 \\
\hline 2533 & Área de expansão - Botucatu - Dispersora - 10 a 18 & 1248893,7 \\
\hline 2534 & Área de expansão - Botucatu - Dispersora - 18 a 33 & 199270,2 \\
\hline 2535 & Área de expansão - Botucatu - Dispersora - > 33 & 7618,3 \\
\hline 3112 & Área Urbana - Coluvionar - Coletora - 5 a 10 & 5700,6 \\
\hline
\end{tabular}




\begin{tabular}{|c|c|c|}
\hline Gridcode & Classe de Terreno (Uso e ocupação - compartimento geotécnico - encosta - declividade em \%) & Área $\left(\mathrm{m}^{2}\right)$ \\
\hline 3113 & Área Urbana - Coluvionar - Coletora - 10 a 18 & 26378,7 \\
\hline 3114 & Área Urbana - Coluvionar - Coletora - 18 a 33 & 8566,1 \\
\hline 3115 & Área Urbana - Coluvionar - Coletora - > 33 & 425,0 \\
\hline 3122 & Área Urbana - Coluvionar - Plana - 5 a 10 & 932,0 \\
\hline 3123 & Área Urbana - Coluvionar - Plana - 10 a 18 & 2193,9 \\
\hline 3124 & Área Urbana - Coluvionar - Plana - 18 a 33 & 300,0 \\
\hline 3132 & Área Urbana - Coluvionar - Dispersora - 5 a 10 & 13573,4 \\
\hline 3133 & Área Urbana - Coluvionar - Dispersora - 10 a 18 & 29519,7 \\
\hline 3134 & Área Urbana - Coluvionar - Dispersora - 18 a 33 & 8026,2 \\
\hline 3135 & Área Urbana - Coluvionar - Dispersora - > 33 & 912,3 \\
\hline 3211 & Área Urbana - Aluvionar - Coletora - 0 a 5 & 769,2 \\
\hline 3212 & Área Urbana - Aluvionar - Coletora - 5 a 10 & 5858,2 \\
\hline 3213 & Área Urbana - Aluvionar - Coletora - 10 a 18 & 4654,5 \\
\hline 3221 & Área Urbana - Aluvionar - Plana - 0 a 5 & 25,0 \\
\hline 3222 & Área Urbana - Aluvionar - Plana - 5 a 10 & 237,8 \\
\hline 3223 & Área Urbana - Aluvionar - Plana - 10 a 18 & 367,8 \\
\hline 3232 & Área Urbana - Aluvionar - Dispersora - 5 a 10 & 325,0 \\
\hline 3233 & Área Urbana - Aluvionar - Dispersora - 10 a 18 & 1695,9 \\
\hline 3311 & Área Urbana - Itaqueri - Coletora - 0 a 5 & 7418255,6 \\
\hline 3312 & Área Urbana - Itaqueri - Coletora - 5 a 10 & 6517879,5 \\
\hline 3313 & Área Urbana - Itaqueri - Coletora - 10 a 18 & 2042202,7 \\
\hline 3314 & Área Urbana - Itaqueri - Coletora - 18 a 33 & 299828,4 \\
\hline 3315 & Área Urbana - Itaqueri - Coletora - > 33 & 6922,4 \\
\hline 3321 & Área Urbana - Itaqueri - Plana - 0 a 5 & 5011805,6 \\
\hline 3322 & Área Urbana - Itaqueri - Plana - 5 a 10 & 1439680,3 \\
\hline 3323 & Área Urbana - Itaqueri - Plana - 10 a 18 & 157693,6 \\
\hline 3324 & Área Urbana - Itaqueri - Plana - 18 a 33 & 10832,3 \\
\hline 3325 & Área Urbana - Itaqueri - Plana - > 33 & 150,0 \\
\hline 3331 & Área Urbana - Itaqueri - Dispersora - 0 a 5 & 13137835,2 \\
\hline 3332 & Área Urbana - Itaqueri - Dispersora - 5 a 10 & 8666135,9 \\
\hline 3333 & Área Urbana - Itaqueri - Dispersora - 10 a 18 & 2539890,8 \\
\hline 3334 & Área Urbana - Itaqueri - Dispersora - 18 a 33 & 383708,8 \\
\hline 3335 & Área Urbana - Itaqueri - Dispersora - > 33 & 12141,0 \\
\hline 3411 & Área Urbana - Serra Geral - Coletora - 0 a 5 & 307531,3 \\
\hline 3412 & Área Urbana - Serra Geral - Coletora - 5 a 10 & 303152,4 \\
\hline 3413 & Área Urbana - Serra Geral - Coletora - 10 a 18 & 260087,4 \\
\hline 3414 & Área Urbana - Serra Geral - Coletora - 18 a 33 & 123002,0 \\
\hline 3415 & Área Urbana - Serra Geral - Coletora - > 33 & 3973,6 \\
\hline 3421 & Área Urbana - Serra Geral - Plana - 0 a 5 & 23495,8 \\
\hline 3422 & Área Urbana - Serra Geral - Plana - 5 a 10 & 25516,8 \\
\hline 3423 & Área Urbana - Serra Geral - Plana - 10 a 18 & 12327,5 \\
\hline 3424 & Área Urbana - Serra Geral - Plana - 18 a 33 & 2726,5 \\
\hline 3425 & Área Urbana - Serra Geral - Plana - > 33 & 75,0 \\
\hline 3431 & Área Urbana - Serra Geral - Dispersora - 0 a 5 & 100298,5 \\
\hline
\end{tabular}




\begin{tabular}{|c|c|c|}
\hline Gridcode & Classe de Terreno (Uso e ocupação - compartimento geotécnico - encosta - declividade em \%) & Área $\left(\mathbf{m}^{2}\right)$ \\
\hline 3432 & Área Urbana - Serra Geral - Dispersora - 5 a 10 & 212848,8 \\
\hline 3433 & Área Urbana - Serra Geral - Dispersora - 10 a 18 & 252461,2 \\
\hline 3434 & Área Urbana - Serra Geral - Dispersora - 18 a 33 & 120161,0 \\
\hline 3435 & Área Urbana - Serra Geral - Dispersora - > 33 & 6332,8 \\
\hline 3511 & Área Urbana -Botucatu - Coletora - 0 a 5 & 606528,7 \\
\hline 3512 & Área Urbana -Botucatu - Coletora - 5 a 10 & 1022674,2 \\
\hline 3513 & Área Urbana -Botucatu - Coletora - 10 a 18 & 314932,0 \\
\hline 3514 & Área Urbana -Botucatu - Coletora - 18 a 33 & 25811,0 \\
\hline 3515 & Área Urbana -Botucatu - Coletora - > 33 & 450,0 \\
\hline 3521 & Área Urbana -Botucatu - Plana - 0 a 5 & 201448,5 \\
\hline 3522 & Área Urbana -Botucatu - Plana - 5 a 10 & 188392,7 \\
\hline 3523 & Área Urbana -Botucatu - Plana - 10 a 18 & 29442,6 \\
\hline 3524 & Área Urbana -Botucatu - Plana - 18 a 33 & 966,0 \\
\hline 3531 & Área Urbana -Botucatu - Dispersora - 0 a 5 & 778857,5 \\
\hline 3532 & Área Urbana -Botucatu - Dispersora - 5 a 10 & 1223389,0 \\
\hline 3533 & Área Urbana -Botucatu - Dispersora - 10 a 18 & 352732,2 \\
\hline 3534 & Área Urbana -Botucatu - Dispersora - 18 a 33 & 26823,3 \\
\hline 3535 & Área Urbana -Botucatu - Dispersora - > 33 & 1788,5 \\
\hline 4111 & Fragmento de Mata - Coluvionar - Coletora - 0 a 5 & 84,1 \\
\hline 4112 & Fragmento de Mata - Coluvionar - Coletora - 5 a 10 & 6180,7 \\
\hline 4113 & Fragmento de Mata - Coluvionar - Coletora - 10 a 18 & 45608,6 \\
\hline 4114 & Fragmento de Mata - Coluvionar - Coletora - 18 a 33 & 41328,0 \\
\hline 4115 & Fragmento de Mata - Coluvionar - Coletora - > 33 & 10832,1 \\
\hline 4122 & Fragmento de Mata - Coluvionar - Plana - 5 a 10 & 298,0 \\
\hline 4123 & Fragmento de Mata - Coluvionar - Plana - 10 a 18 & 2528,0 \\
\hline 4124 & Fragmento de Mata - Coluvionar - Plana - 18 a 33 & 1155,0 \\
\hline 4125 & Fragmento de Mata - Coluvionar - Plana - > 33 & 216,0 \\
\hline 4132 & Fragmento de Mata - Coluvionar - Dispersora - 5 a 10 & 7457,1 \\
\hline 4133 & Fragmento de Mata - Coluvionar - Dispersora - 10 a 18 & 49943,0 \\
\hline 4134 & Fragmento de Mata - Coluvionar - Dispersora - 18 a 33 & 40303,4 \\
\hline 4135 & Fragmento de Mata - Coluvionar - Dispersora - > 33 & 11966,0 \\
\hline 4211 & Fragmento de Mata - Aluvionar - Coletora - 0 a 5 & 393817,9 \\
\hline 4212 & Fragmento de Mata - Aluvionar - Coletora - 5 a 10 & 47669,9 \\
\hline 4213 & Fragmento de Mata - Aluvionar - Coletora - 10 a 18 & 20520,0 \\
\hline 4214 & Fragmento de Mata - Aluvionar - Coletora - 18 a 33 & 10424,2 \\
\hline 4215 & Fragmento de Mata - Aluvionar - Coletora - > 33 & 1049,1 \\
\hline 4221 & Fragmento de Mata - Aluvionar - Plana - 0 a 5 & 95936,9 \\
\hline 4222 & Fragmento de Mata - Aluvionar - Plana - 5 a 10 & 1876,8 \\
\hline 4223 & Fragmento de Mata - Aluvionar - Plana - 10 a 18 & 316,0 \\
\hline 4224 & Fragmento de Mata - Aluvionar - Plana - 18 a 33 & 325,0 \\
\hline 4231 & Fragmento de Mata - Aluvionar - Dispersora - 0 a 5 & 157020,4 \\
\hline 4232 & Fragmento de Mata - Aluvionar - Dispersora - 5 a 10 & 22573,2 \\
\hline 4233 & Fragmento de Mata - Aluvionar - Dispersora - 10 a 18 & 11682,5 \\
\hline 4234 & Fragmento de Mata - Aluvionar - Dispersora - 18 a 33 & 10324,4 \\
\hline
\end{tabular}




\begin{tabular}{|c|c|c|}
\hline Gridcode & Classe de Terreno (Uso e ocupação - compartimento geotécnico - encosta - declividade em \%) & Área $\left(\mathbf{m}^{2}\right)$ \\
\hline 4235 & Fragmento de Mata - Aluvionar - Dispersora - > 33 & 930,7 \\
\hline 4311 & Fragmento de Mata - Itaqueri - Coletora - 0 a 5 & 1032955,8 \\
\hline 4312 & Fragmento de Mata - Itaqueri - Coletora - 5 a 10 & 1372127,5 \\
\hline 4313 & Fragmento de Mata - Itaqueri - Coletora - 10 a 18 & 872740,3 \\
\hline 4314 & Fragmento de Mata - Itaqueri - Coletora - 18 a 33 & 314827,8 \\
\hline 4315 & Fragmento de Mata - Itaqueri - Coletora - > 33 & 61796,9 \\
\hline 4321 & Fragmento de Mata - Itaqueri - Plana - 0 a 5 & 267508,7 \\
\hline 4322 & Fragmento de Mata - Itaqueri - Plana - 5 a 10 & 170884,2 \\
\hline 4323 & Fragmento de Mata - Itaqueri - Plana - 10 a 18 & 53041,3 \\
\hline 4324 & Fragmento de Mata - Itaqueri - Plana - 18 a 33 & 9711,7 \\
\hline 4325 & Fragmento de Mata - Itaqueri - Plana - > 33 & 1153,1 \\
\hline 4331 & Fragmento de Mata - Itaqueri - Dispersora - 0 a 5 & 807882,3 \\
\hline 4332 & Fragmento de Mata - Itaqueri - Dispersora - 5 a 10 & 1171342,4 \\
\hline 4333 & Fragmento de Mata - Itaqueri - Dispersora - 10 a 18 & 1003033,7 \\
\hline 4334 & Fragmento de Mata - Itaqueri - Dispersora - 18 a 33 & 452609,0 \\
\hline 4335 & Fragmento de Mata - Itaqueri - Dispersora - > 33 & 103945,6 \\
\hline 4411 & Fragmento de Mata - Serra Geral - Coletora - 0 a 5 & 26224,1 \\
\hline 4412 & Fragmento de Mata - Serra Geral - Coletora - 5 a 10 & 29851,1 \\
\hline 4413 & Fragmento de Mata - Serra Geral - Coletora - 10 a 18 & 92753,6 \\
\hline 4414 & Fragmento de Mata - Serra Geral - Coletora - 18 a 33 & 231375,6 \\
\hline 4415 & Fragmento de Mata - Serra Geral - Coletora - > 33 & 163849,1 \\
\hline 4421 & Fragmento de Mata - Serra Geral - Plana - 0 a 5 & 316,0 \\
\hline 4422 & Fragmento de Mata - Serra Geral - Plana - 5 a 10 & 1615,2 \\
\hline 4423 & Fragmento de Mata - Serra Geral - Plana - 10 a 18 & 3423,5 \\
\hline 4424 & Fragmento de Mata - Serra Geral - Plana - 18 a 33 & 5989,9 \\
\hline 4425 & Fragmento de Mata - Serra Geral - Plana - > 33 & 3690,7 \\
\hline 4431 & Fragmento de Mata - Serra Geral - Dispersora - 0 a 5 & 2006,2 \\
\hline 4432 & Fragmento de Mata - Serra Geral - Dispersora - 5 a 10 & 23731,9 \\
\hline 4433 & Fragmento de Mata - Serra Geral - Dispersora - 10 a 18 & 98740,3 \\
\hline 4434 & Fragmento de Mata - Serra Geral - Dispersora - 18 a 33 & 261925,4 \\
\hline 4435 & Fragmento de Mata - Serra Geral - Dispersora - > 33 & 223858,1 \\
\hline 4511 & Fragmento de Mata - Botucatu - Coletora - 0 a 5 & 723631,3 \\
\hline 4512 & Fragmento de Mata - Botucatu - Coletora - 5 a 10 & 1209490,4 \\
\hline 4513 & Fragmento de Mata - Botucatu - Coletora - 10 a 18 & 1037408,2 \\
\hline 4514 & Fragmento de Mata - Botucatu - Coletora - 18 a 33 & 543715,8 \\
\hline 4515 & Fragmento de Mata - Botucatu - Coletora - > 33 & 239363,1 \\
\hline 4521 & Fragmento de Mata - Botucatu - Plana - 0 a 5 & 158763,8 \\
\hline 4522 & Fragmento de Mata - Botucatu - Plana - 5 a 10 & 175601,5 \\
\hline 4523 & Fragmento de Mata - Botucatu - Plana - 10 a 18 & 68936,3 \\
\hline 4524 & Fragmento de Mata - Botucatu - Plana - 18 a 33 & 13554,5 \\
\hline 4525 & Fragmento de Mata - Botucatu - Plana - > 33 & 3076,8 \\
\hline 4531 & Fragmento de Mata - Botucatu - Dispersora - 0 a 5 & 585259,0 \\
\hline 4532 & Fragmento de Mata - Botucatu - Dispersora - 5 a 10 & 1213075,9 \\
\hline 4533 & Fragmento de Mata - Botucatu - Dispersora - 10 a 18 & 1059993,5 \\
\hline
\end{tabular}




\begin{tabular}{|c|c|c|}
\hline Gridcode & Classe de Terreno (Uso e ocupação - compartimento geotécnico - encosta - declividade em \%) & Área $\left(\mathbf{m}^{2}\right)$ \\
\hline 4534 & Fragmento de Mata - Botucatu - Dispersora - 18 a 33 & 480567,8 \\
\hline 4535 & Fragmento de Mata - Botucatu - Dispersora - > 33 & 190694,4 \\
\hline 5511 & Indústria - Botucatu - Coletora - 0 a 5 & 113916,7 \\
\hline 5512 & Indústria - Botucatu - Coletora - 5 a 10 & 537962,1 \\
\hline 5513 & Indústria - Botucatu - Coletora - 10 a 18 & 141525,0 \\
\hline 5514 & Indústria - Botucatu - Coletora - 18 a 33 & 15514,0 \\
\hline 5521 & Indústria - Botucatu - Plana - 0 a 5 & 22583,7 \\
\hline 5522 & Indústria - Botucatu - Plana - 5 a 10 & 118722,8 \\
\hline 5523 & Indústria - Botucatu - Plana - 10 a 18 & 13278,7 \\
\hline 5524 & Indústria - Botucatu - Plana - 18 a 33 & 382,0 \\
\hline 5531 & Indústria - Botucatu - Dispersora - 0 a 5 & 115886,3 \\
\hline 5532 & Indústria - Botucatu - Dispersora - 5 a 10 & 592073,0 \\
\hline 5533 & Indústria - Botucatu - Dispersora - 10 a 18 & 160841,9 \\
\hline 5534 & Indústria - Botucatu - Dispersora - 18 a 33 & 15911,2 \\
\hline 6311 & Reflorestamento - Itaqueri - Coletora - 0 a 5 & 1158340,6 \\
\hline 6312 & Reflorestamento - Itaqueri - Coletora - 5 a 10 & 878863,0 \\
\hline 6313 & Reflorestamento - Itaqueri - Coletora - 10 a 18 & 331863,5 \\
\hline 6314 & Reflorestamento - Itaqueri - Coletora - 18 a 33 & 20044,1 \\
\hline 6315 & Reflorestamento - Itaqueri - Coletora - > 33 & 4461,2 \\
\hline 6321 & Reflorestamento - Itaqueri - Plana - 0 a 5 & 942749,7 \\
\hline 6322 & Reflorestamento - Itaqueri - Plana - 5 a 10 & 202638,4 \\
\hline 6323 & Reflorestamento - Itaqueri - Plana - 10 a 18 & 33938,3 \\
\hline 6324 & Reflorestamento - Itaqueri - Plana - 18 a 33 & 357,0 \\
\hline 6325 & Reflorestamento - Itaqueri - Plana - > 33 & 50,0 \\
\hline 6331 & Reflorestamento - Itaqueri - Dispersora - 0 a 5 & 1939354,1 \\
\hline 6332 & Reflorestamento - Itaqueri - Dispersora - 5 a 10 & 1108424,9 \\
\hline 6333 & Reflorestamento - Itaqueri - Dispersora - 10 a 18 & 404404,3 \\
\hline 6334 & Reflorestamento - Itaqueri - Dispersora - 18 a 33 & 24860,5 \\
\hline 6335 & Reflorestamento - Itaqueri - Dispersora - > 33 & 4122,6 \\
\hline 6511 & Reflorestamento - Botucatu - Coletora - 0 a 5 & 1495358,9 \\
\hline 6512 & Reflorestamento - Botucatu - Coletora - 5 a 10 & 409388,3 \\
\hline 6513 & Reflorestamento - Botucatu - Coletora - 10 a 18 & 161293,1 \\
\hline 6514 & Reflorestamento - Botucatu - Coletora - 18 a 33 & 18726,5 \\
\hline 6521 & Reflorestamento - Botucatu - Plana - 0 a 5 & 923280,0 \\
\hline 6522 & Reflorestamento - Botucatu - Plana - 5 a 10 & 87110,6 \\
\hline 6523 & Reflorestamento - Botucatu - Plana - 10 a 18 & 13831,1 \\
\hline 6524 & Reflorestamento - Botucatu - Plana - 18 a 33 & 516,9 \\
\hline 6531 & Reflorestamento - Botucatu - Dispersora - 0 a 5 & 1138793,6 \\
\hline 6532 & Reflorestamento - Botucatu - Dispersora - 5 a 10 & 452082,3 \\
\hline 6533 & Reflorestamento - Botucatu - Dispersora - 10 a 18 & 193643,4 \\
\hline 6534 & Reflorestamento - Botucatu - Dispersora - 18 a 33 & 20295,6 \\
\hline
\end{tabular}


APÊNDICE D - Mapa de suscetibilidade a movimentos de encosta 


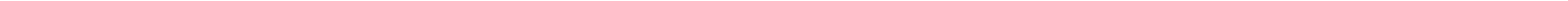


APÊNDICE E - Mapa de suscetibilidade a erosões pluviais 


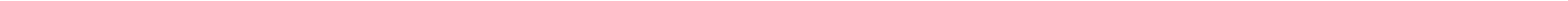


APÊNDICE F - Mapa de Suscetibilidade a colapso de solos 


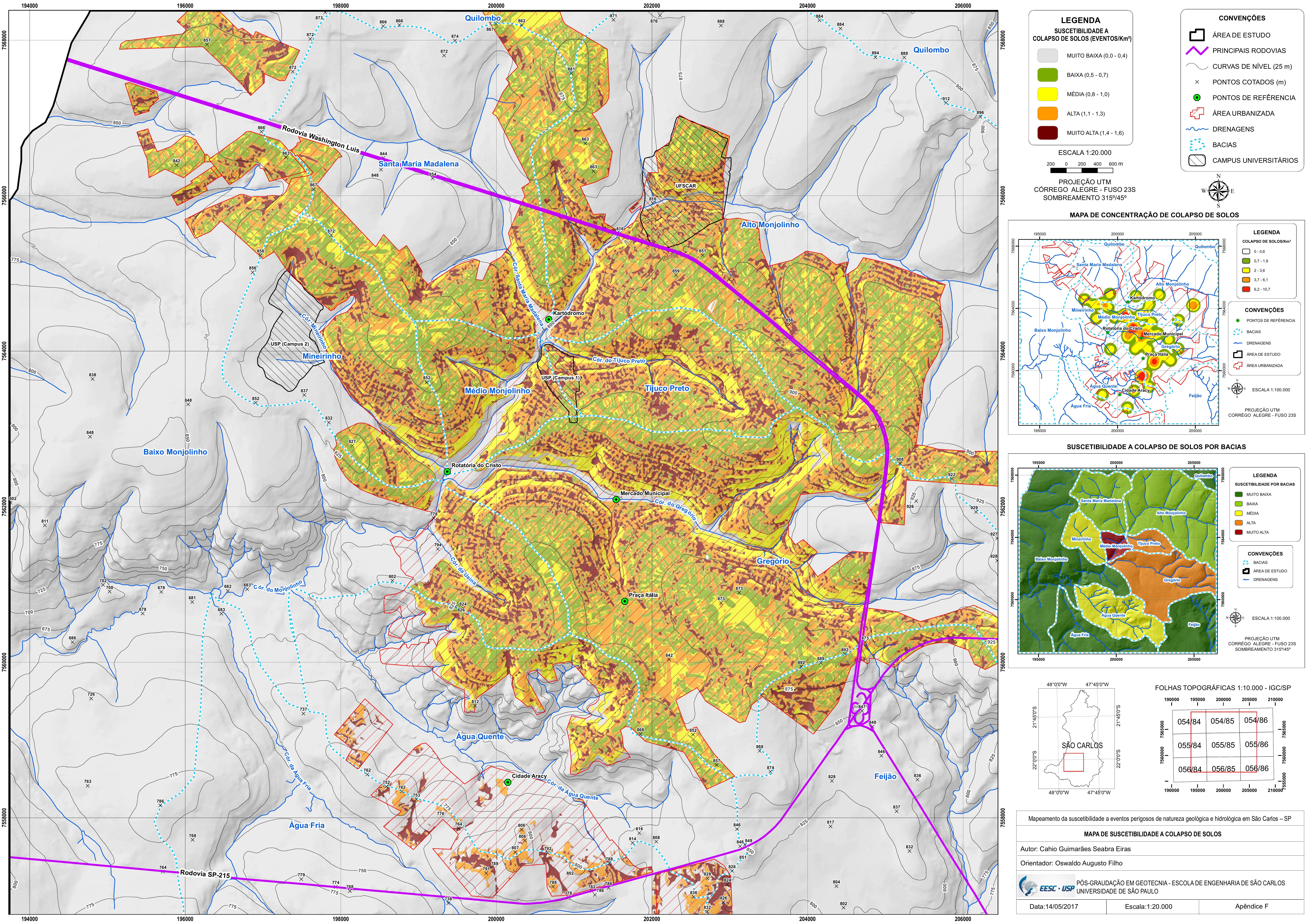


APÊNDICE G - Mapa de suscetibilidade a enchentes/inundações 


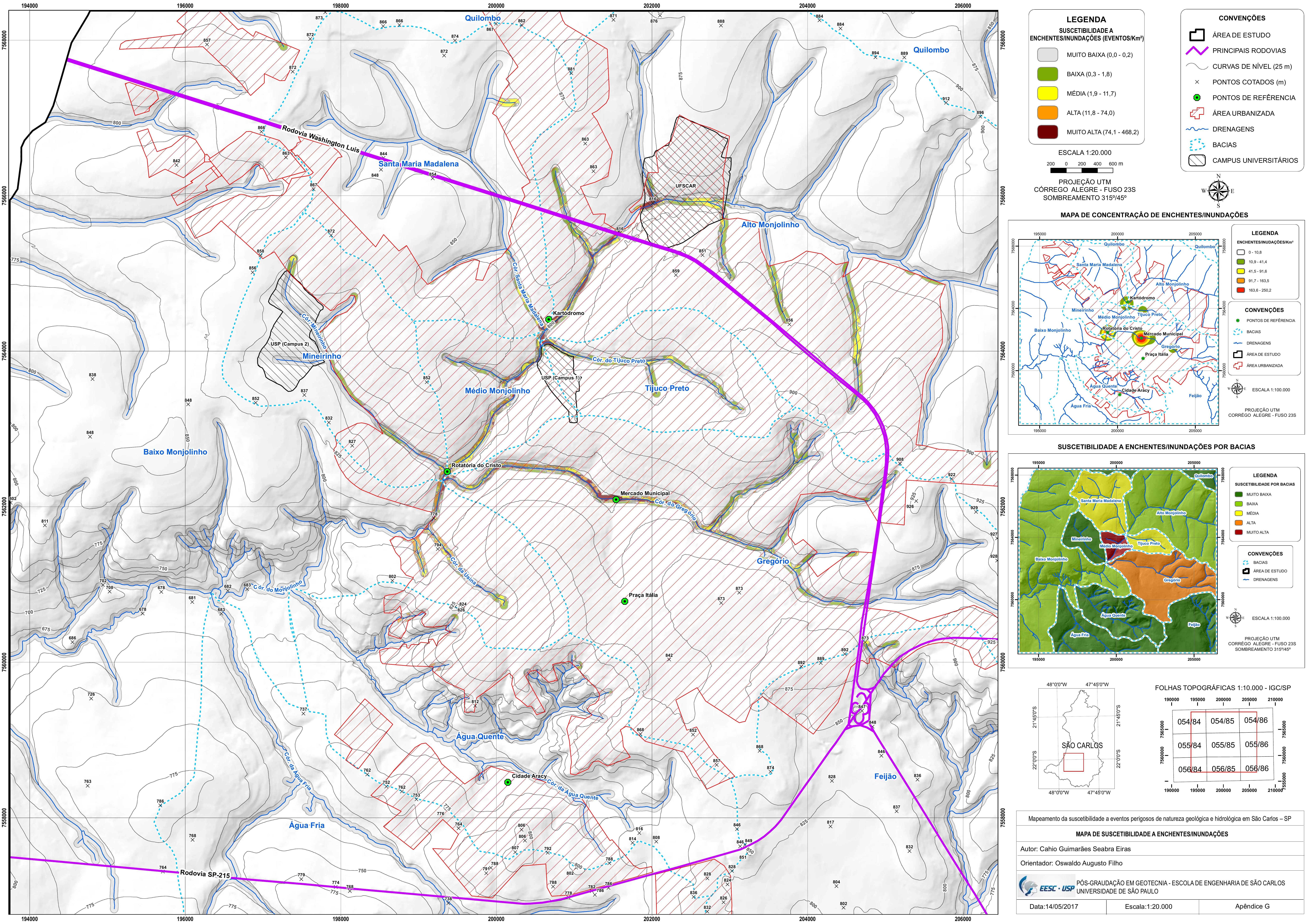

